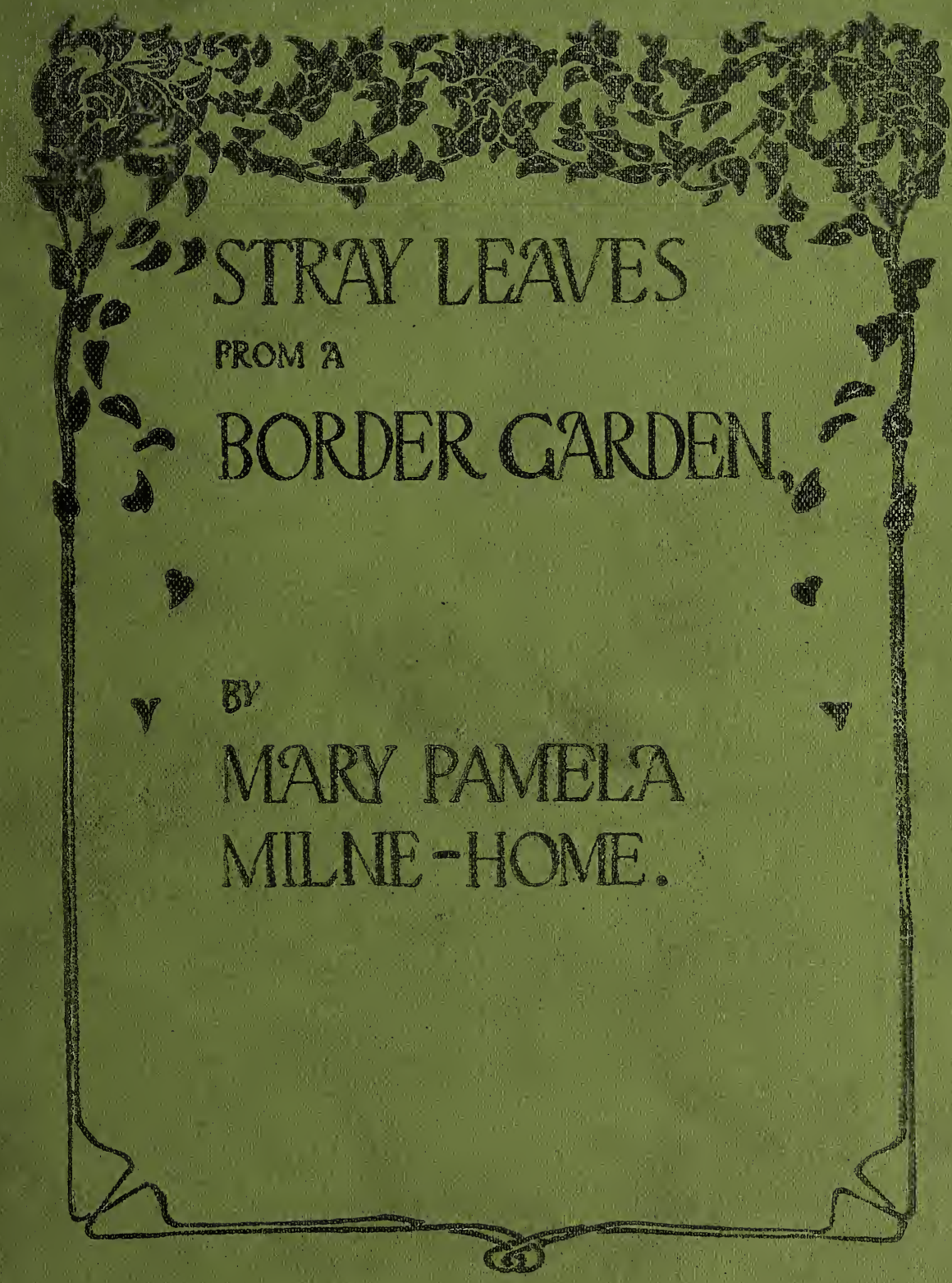




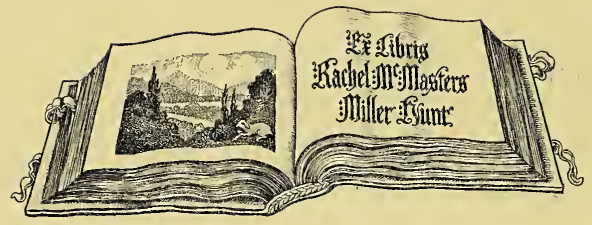

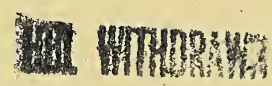



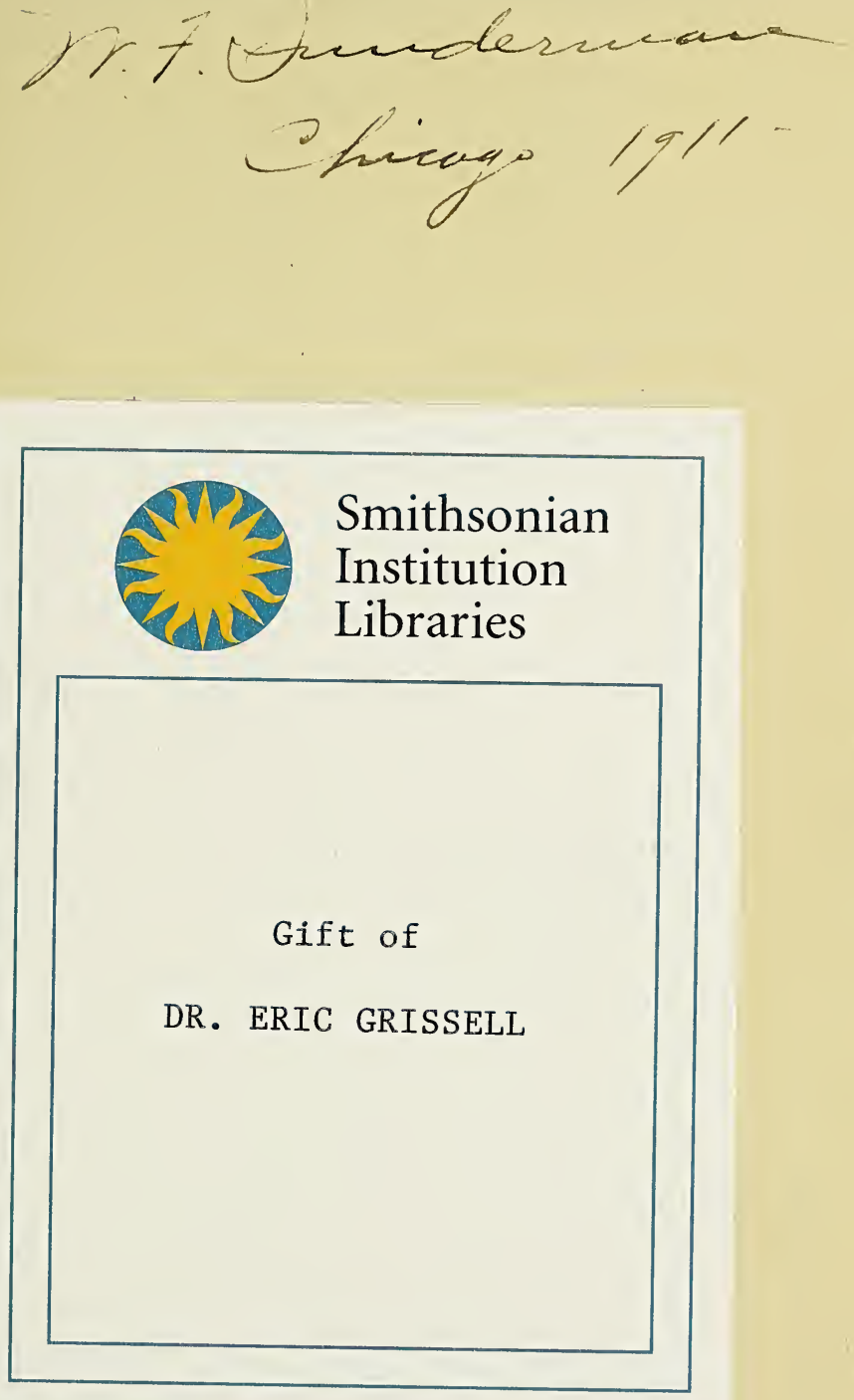

STRAY LEAVES FROM A

BORDER GARDEN 



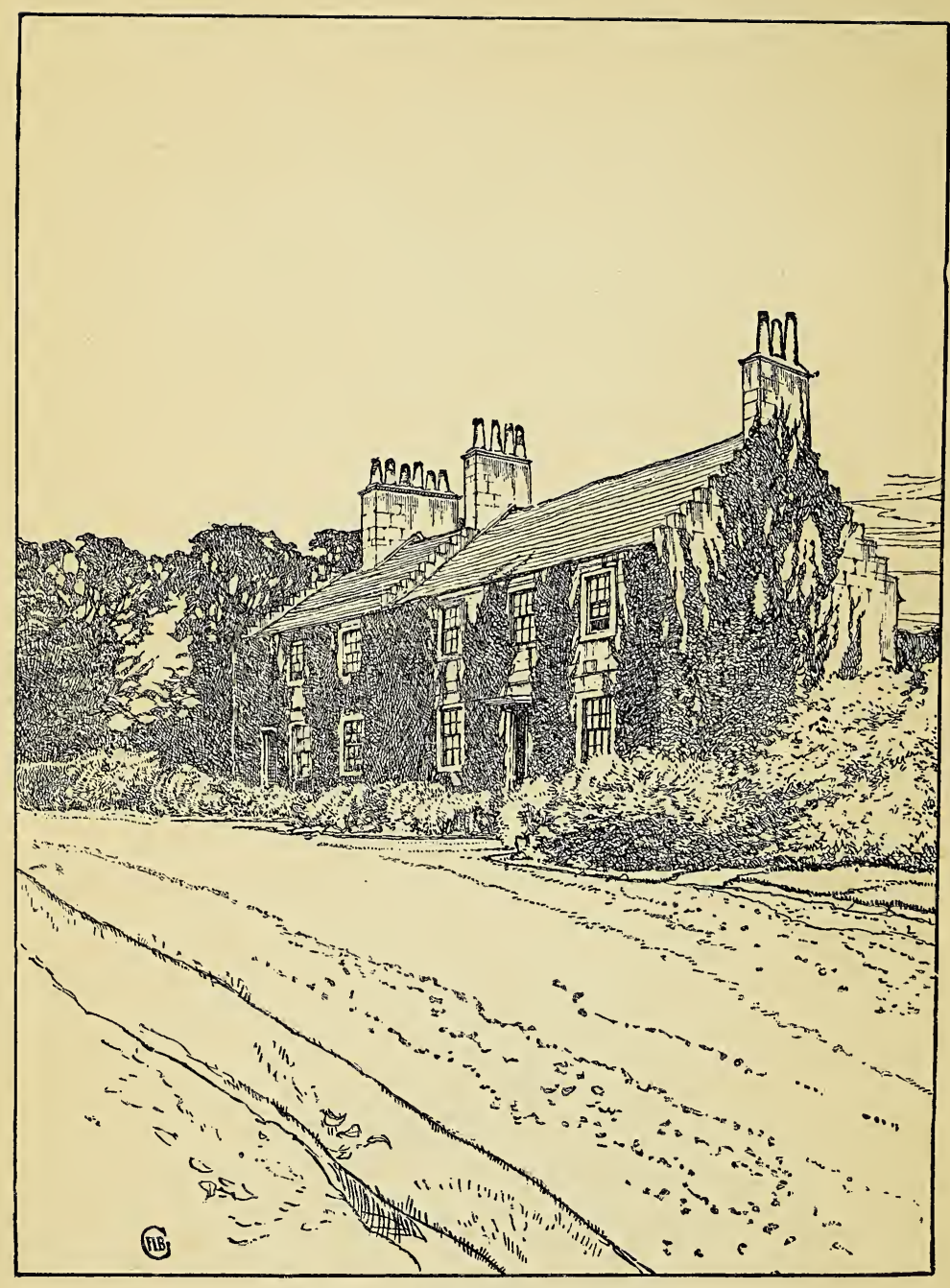

The Old Mansionhouse. 


\section{STRAY LEAVES FROM A BORDER GARDEN}

BY

MARY PAMELA MILNE-HOME AUTHOR OF

"MAMMA'S BLACK NURSE STORIES; WEST INDIAN FOLK-LORE"

WITH EIGHT ILLUSTRATIONS BY F. L. B. GRIGGS

$\cos ^{6} \cos _{8}^{6}$

JOHN LANE: THE BODLEY HEAD LONDON AND NEW YORK: MDCCCCI 
Printed by Ballantyne, Hanson $\&$ Co.

London \& Edinburgh 


\section{MY MOTHER}

"The year's at the spring, The day's at the morn, Morning's at seven;

The hillside's dew-pearled, The lark's on the wing, The snail's on the thorn. God's in his heaven, All's right with the wovld."

R. BROWNING 



\section{PREFACE}

Most of the verses in this little book, as also some of the stories in the Second Part, are republished by kind permission of the Editor of The Lady. By the courtesy of the Editor of the Border Magazine I am enabled to make use of an article concerning the Yetholm gipsies by A. M. M. H. I am also indebted to Messrs. Smith and Elder for kindly allowing me to quote somewhat from Ralston's "Russian Folk Tales." I would thank Mr. Heinemann, the publisher of Aston's " History of Japanese Literature"; Messrs. Blackwood; Messrs. Nimmo, Hay, and Mitchell ; Mr. David Douglas; Mr. George Muirhead, F.R.S.E., F.Z.S. ; Messrs. Chatto \& Windus ; and Messrs. Macmillan for kindly allowing me to refer to books published by them.

Here let me borrow some of the graphic expressions of my dear old Queen Anne herbalist, Salmon, and say :

"As to the Authors made ufe of this Undertaking we fhall not be fo vain as to enumerate them all, t'would be to no Purpofe, and yet Gratitude demands an Account of the Chief of thofe in Treating of Border and other Things, whofe leaves we were continually obliged to turn over."

The Authors we made most use of in compiling this home notebook were the following: "Johnston's "Natural History of the Eastern Borders"; Henderson's "Popular Rhymes of Berwickshire"; "Smith's "Scotish Minstrel"; Jamieson's "Scottish Dictionary" (Nimmo, Hay, and Mitchell); Dr. R. C. Prior's "Popular Names of British Plants"; Salmon's " English Herbal"; Barton \& Castle's 


\section{Preface}

"Brit. Flora Medica"; Thiselton Dyer's "Folk-lore of Plants" (Chatto \& Windus); Ralston's "Russian Folk Tales (Smith \& Elder); Aston's "History of Japanese Literature" (Heinemann) ; Muirhead's "Birds of Berwickshire" (David Douglas); Prof. Veitch's "History and Poetry of the Scottish Border" (Blackwood).

"Thefe I fay were thofe which were chiefly confulted, and without whom we paffed not off from the Difcourfe of any Plant. But we cannot fay thefe were All, for occafionally as it fell in our way, and when fome particular Occurrence required it, we had recourfe to many others, more than twice that number befides, without the Help of which we could not fo Compleatly have performed what we here Prefent you withall."

Hoping you will of your Courtesy, Gentle Reader, give it Gentle Judgment, remembering it hath been said the province of a Woman is to chronicle small beer.

MARY PAMELA MILNE HOME.

Caldra. 


\section{NOV 162005}

\section{Lion-mers}

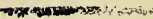

\section{CONTENTS}

PART I

\section{STRAY LEAVES FROM A BORDER GARDEN}

1. Martinmas to Ladyday Page 3

II. Ladyday to Whit Sunday

III. Hallowe'en to Candlemas 52

IV. Candlemas to Lammas 75

V. The Chrissenmas to Mayday 94

VI. "All in ye Merrie Month of May"

VII. A Thirsty June

VIII. Midsummer to Michaelmas

IX. Harvesting the Hedges

X. Visions and Rumours of $\mathrm{W}$ ar

XI. The Wearing of the Shamrock and Rose 260

XII. Kinship amongst Flower-Names and Bird-Names 267 XIII. Vernacular of the Border 289 


\title{
Contents
}

\author{
PART II
}

\section{MY FRIENDS IN THEIR GARDENS}

Mrs. Moss

Page 297

John Burnet

301

The Major

304

Madame Krach

306

The Rector

309

Lotosland

312

Jacob

316

Our Lady of Roses

320

Corbie Hall

322

Padre Avelino

Little Reine des Cieux

335

Mistress Bell 


\section{ILLUSTRATIONS}

The Old Mansionhouse

Caldra Mains

The Waterside Croft

Cottages at Fogo

The Blackadder from the Footbridge

Fogo Church

Fogo Bridge

Blackadder below Caldra
Frontispiece

To face page 6

50

70

180

210

212

216 



\section{PART I}

\section{STRAY LEAVES FROM A BORDER GARDEN}





\section{CHAPTER I}

\section{MARTINMAS TO LADYDAY}

A GARDEN presupposes a house, but in how many cases a house is merely the savage definition of a home, "a place of shelter"; indeed, the Australian savage, I believe, calls his hut a "breakwind." In our case it is an old house, not old enough, however, to have known the stirring times of the Border, when "clumps" of spears rode out to raid, and little was recked of gardens. It is about a couple of hundred years since the first half of it arose on the bank above the little trout-river, and less than a hundred since the addition was made which resulted in two front doors on the north side of the old grey house, and a double row of moss-grown crowsteps, crowstairs, or catsteps, as some call them, on the roof. I wonder why they are so called; I have never seen either cats or crows make any use of them; and although flights of rooks do pass over the house morning and evening, they never pause to rest on them. Only the starlings sit there and clamour. Craw for rook must be Scottish, for both Scott and Burris talk of crows when apparently they mean rooks. A flight of rooks is sometimes called a "craw's bridal." Ivy grows thickly all over the walls, and invades even the rowens, and festoons the area railing in front that fences in a bank, which in spring is just a mass of snowdrops. Sparrows infest the ivy, and I fear the swallows will soon be ousted. In Roumania swallows are called God's fowls (Galinele lui Dieu), and a treasure lies hid wherever the first swallow of the 


\section{Stray Leaves from a Border Garden}

spring alights. It is so lucky to have swallows' nests; it is said no house can ever be burnt where swallows build. In Russia there is a similar belief, and it is further deemed very unlucky to kill swallows, since the swallows were said to have stolen away the nails that the Jews were going to use to fasten the Saviour to the cross, while the sparrows brought them back and are considered accursed in consequence.

Within, our house is a nest of tiny low rooms, with wooden beds, chintz curtains, a best bedroom with an ancient fourposter which certainly never got in whole, treasures of old Spode china, corner cupboards, and mysterious " hidieholes" in the thickness of the old walls, bead-embroidered screens and tables, carved whatnots, old weapons, and ancient prints of dead and gone worthies, friends of those gone from here; such as Lord Lynedoch, the faithful lover and gallant Peninsular hero who would not be buried in Westminster Abbey among the great ones of the earth, but declared he would rather lie as Thomas Graham of Balgowan in the Scottish kirkyard of Methven by the side of his long-lost love and fair bride, whose picture still adorns the National Gallery in Edinburgh. There was a coloured print of this picture among the many relics of the past, and I fell in love at once with the sweetfaced bride in her feathered hat, and gave her a place of honour in our little sunny parlour-I cannot call it a drawing-room, it is too small and old-fashioned. One can quite imagine Mrs. Fairchild, Mrs. Howard or Mrs. Goodriche sitting in it. Indeed, I should not feel surprised, I think, if Miss Grizzy and Miss Jacky, so delightfully described by Miss Ferrier, were to walk in, for these old gentlewomen are not quite extinct yet: I know of an old Scots home or two where a Miss Grizzy still makes her friends welcome with the old-time Scotch hospitality. The place is full of all the quaint lumber which gathers in an old secluded house which has been forgotten of its owners and let continuously for a long time in short periods. At last it has fallen to our lot. How well I remember the 


\section{Martinmas to Ladyday}

first coming to our little Border home, in the golden light of an Indian summer's day, when the sun was glinting on the cornfields ard gilding the yellowing leaves of the many trees which close round the old mansion-house and keep it so well from the bitter winds which sweep down from the moors! November is not the ideal month of many, yet sometimes St. Martin's summer is perfection, with its bright clear tints of far-off hill and distance, and warm sun combined with a crisp cleanness in the air which is invigorating and inspiriting to a degree. As we drove past the substantial-looking red-tiled grey stone farmsteading, in at the old stone gateway, certainly the leaves came whirling down from the lindens which bordered the small winding avenue, and there were many branches bare. But there were giant ferns in abundance, under the trees, and scurrying happy rabbits, and a robin in an old crooked laburnum was carolling a lusty welcome.

There is a nameless charm about some old houses, and none who ever sojourned here but have come under its spell and remembered it when far away, even coming to inquire of its welfare if in its vicinity after they had ceased to inhabit it. I fell in love with the old house the very first day, even though I nearly broke my neck down the dark winding stone stair, and was aroused at an unholy hour in the morning by the twitter of a myriad birds singing matins in the ivy. It had the attraction of a ghost too, a white mouse with pink eyes, said to haunt the pantry. I never saw it, much as I longed to do so, but I can vouch for many living mice of more sombre hue. How strange it was to wake at night and only hear the mice in the wainscot, the "rurall myss" as the old writers termed them; the owls shrieking to each other! What an eerie sound it is till one gets used to it and the eternal ripple of the river, after the hubbub of the city whence we had come! I felt in a perfect maze wandering about the tangled overgrown garden, and I was positively a week in the place before I discovered the entry into a certain little crescentshaped garden I saw from the attic window and desired 


\section{Stray Leaves from a Border Garden}

ardently to visit. But it seemed to evade me, in the tangle of syringa and wild roses which linked the overgrown laurels together. I never could find out the path to it, till at last one day, behind a fallen Irish yew, I fancied I descried a tiny iron gate. The Man with the Axe, who at present haunts here, being summoned, speedily cleared a way, and I found myself in a dear little enclosed garden, where it is evident in spring there will be masses of primroses. In the meantime it is all beechmast from the overhanging big beech-tree, and evidently a favourite squirrel haunt. I must plant lilies here; it looks just the place for them, if only it does not prove too shady. Trees, trees, trees, even laurel-trees, broom and giant nettles and wild roses make a wood like that of the Sleeping Beauty; one almost expects to see the Prince come wandering along the grass-grown paths invaded by the primroses and London Pride. No near neighbours ; only the Gateway Farm, with its massive stone entrance and front covered with honeysuckle and Flame flower, its windows full of red and white geraniums, and by the door the row of silvery herrings threaded on a stick without which no Borderer's door is complete, and over it an old rusty horseshoe. I remember one day I inquired as to the meaning of the horseshoe, and the farmer's wife said it meant nothing, it was just there for a bit of foolishness. I believe, all the same, it owed its elevation to a lurking belief in its efficacy to keep off ghosts and witches, such as caused the carving of horseshoes on the little stone prie-dieu in Melrose Abbey, which in a crabbed Latin inscription requests to this day prayers for the soul of Brother Peter the treasurer. Beyond the little river, or the "Water," as it is called here, stands an ancient ivied kirk, with its modern manse, a few slated and thatched cottages near by, and, of course, the inevitable Board school. Very soon, alas, thatchers will be unknown on the Border, and the pretty art will be forgotten. Great tranquillity, only broken by the occasional cries to his team of Jock the ploughman in the neighbouring fields, or children at play on the farther river bank. I think I will keep a 


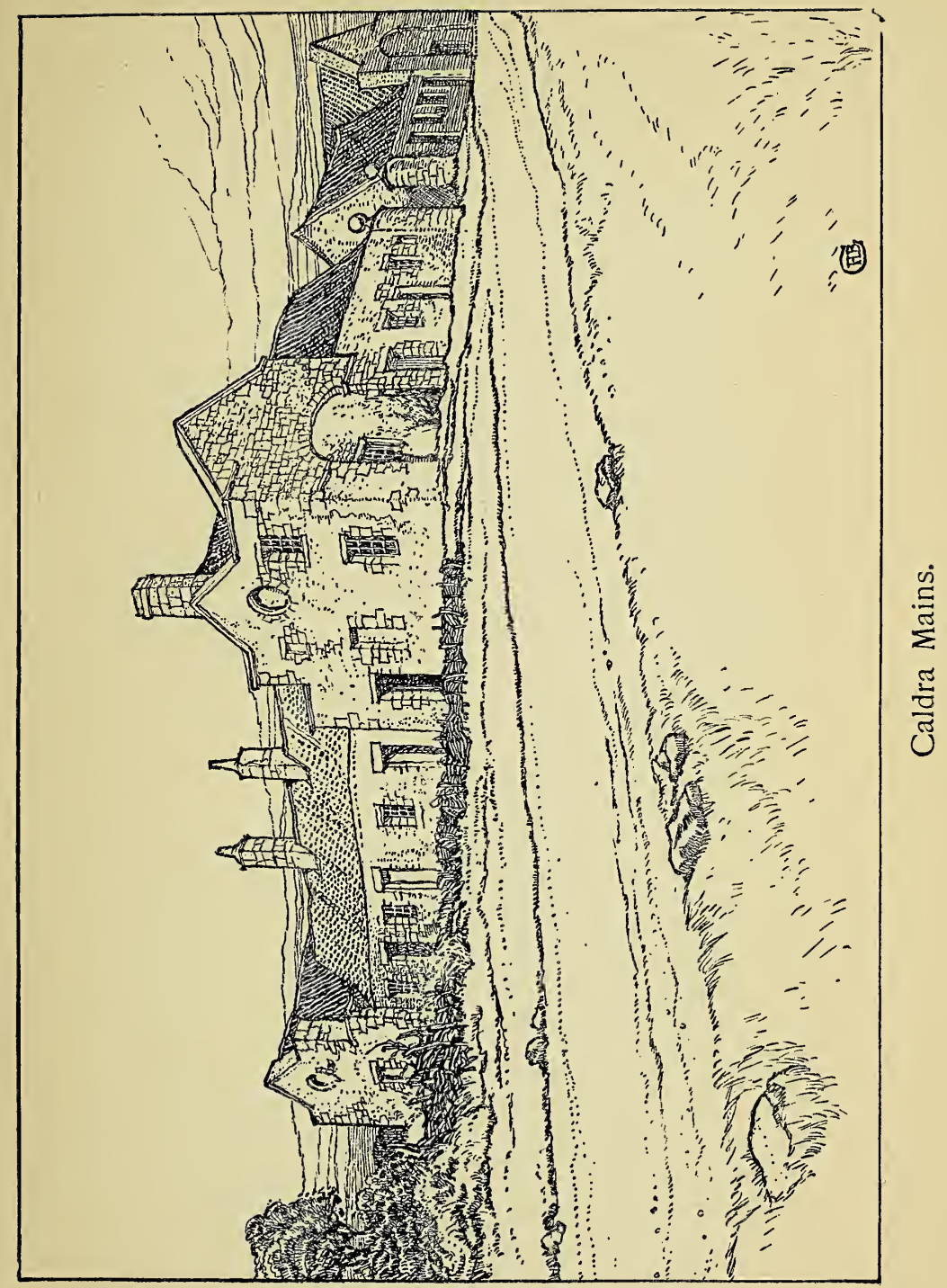





\section{Martinmas to Ladyday}

Flower Diary. I wish I had begun earlier, but, after all, March used to be the beginning of the year long ago. It was, I believe, in $7 \times 3$ B.c. that Numa arranged that the Roman Kalendar should begin with January and February. The name January comes from the dedication of this month by the Romans to Janus, the doorkeeper of Olympia, and also the God of Peace: thus it is the opening month of the year, when the earth is at rest. The Saxons called it Aefter Yula. Now let me see what do I remember. In January we found a few early snowdrops, and gradually all the banks became white with them. Such banks, with tall slim beech or elm trees, feathery rowans or quickens, and literally carpeted underfoot with the funny round "cabbages" of the London Pride, called hereabouts "None so pretty" and "Nancy Pretty." In Ireland it is called St. Patrick's Cabbage. It is strange to think how it is a lingering, lonely, humble remnant of the Alpine flora which was here in the days when all was snow and ice, and woolly mammoths roamed to and fro. There is a quaint old saying about the rowantree :

Roantree and red thread

Haud the witches all in dread.

The legend of the Lothly Toad of Bamborough Castle deals with this saying.

Once upon a time, so the story goes, the second wife of a certain Lord of Bamboro' was a witch, who, being jealous of her husband's children, drove out his son to wander the wide world and changed his beautiful daughter into a toad. She was condemned to remain a toad till her brother should come back and free her from enchantment. His attempts to do so were at first all in vain, because of the spells whereby the witch had encompassed the castle. But at last a wise woman advised the poor brother to build a ship of rowan wood, and have the ropes and sails all bound with red thread. The wicked stepmother, seeing from her bower the ship coming sailing over the sea, sent out a 


\section{Stray Leaves from a Border Garden}

flight of witches to destroy it, but in vain; the young man prevailed, as the ballad says :

The spells were vain ; the hags returned

To the Queen in sorrowful mood,

Crying that witches have no power

Where there is Roantree wocd.

Bamborough Castle is said to be the Castel Orgueilleux mentioned in my kinsman, George Ellis's "Metrical Romances."

In February, such was the mildness of the weather, we actually gathered in the old red-walled kitchen-garden a posy of a dozen pink and yellow primroses, brown auriculas, "cousin to primrose," Boy calls them, in which he is more correct than he knows, since the old name for auriculas was "primrose bear's ear." A Gloucestershire name is " tanner's apron." In Roxburghshire the auricula was called "cat's lug," meaning "cat's ear." "French cowslips" is a pretty old name mentioned by Parkinson. It was deemed a sovereign remedy, when made into a balsam, "against the bitings of the Sea-Hare and of the Toad." At least so says my old Queen Anne Herbal, where the information is of a most uncommon kind. What species of animal a sea-hare is I have yet to find out, since my Herbal telleth not. One golden wallflower-Boy is as keen after wallflower as a rabbit, and nips off an early bloom before I can look round-one violet, growing in a strawherry bed, some sweet white arabis right in the middle of my tiny wild strawberry bed, one early golden crocus, and some naked-jasmine against the wall. There is in this kitchen-garden such a dear old arbour called the Lady's Bower; Lady was the title formerly given, it seems, to all wives of landholders, such as Lady Billy, whose husband was a Mr. Ninian Home, owning the Billy estate in the middleof the eighteenth century. Lady, I believe, came from an old Saxon word meaning the "loafgiver" or "household bread dispenser," a rather nice meaning, I think. This arbour is cut out of an ancient holly-tree with a hawthorn growing entwined with it, haunted 


\section{Martinmas to Ladyday}

by numberless birds; such a delightful place to take refuge in on a windy day, with low apple-trees and white lilies in front, and a pretty view of the little church on the grassy brae beyond the river! Wallace is said to have hidden once upon a time, when hard pressed, in a holly hedge. I should think it would hide any one well, it is so thick. Holleyns they are called here ; a very old name, which is used in many an antient Border ballad. Pliny declares holly flowers make water to freeze, and if a holly-stick be thrown at any creature, it so affects it that the animal is obliged to lie down beside it. In Derbyshire a cure for chilblains was to beat the sore place with a holly spray! I have heard it was customary at Roman weddings to present wreaths of holly. The name " holly" is said to come from holy-tree because it was used to deck churches at Christmas-time, and an old name for the holly was Christmas. This custom is by some people believed to have originated with the Druids, who took branches of woodland trees into the shelter of their homes with the fancy that the spirits of the wood should have a refuge from the winter cold till the trees were green again; rather a pretty idea I think. Southey admired the holly-tree very much and wrote a charming little poem about it. It used also to be called Holme and Hulver ; this last is, I believe, a corruption of the French word Olivier, as it did duty for olive branches in old Church festivals. The catkins are out in the lane now; how pretty they are, like drops of snow caught on the bare brown branches of the saughs! This word is probably a survival of the Anglo-Saxon "sealh-sallows," a name, I think, from the Finnish "salawa." "Catlings" and "pussies" the children here call them, and sometimes " goslings "; "pussy willow " is the American name. It is odd that the German name should be also Kätzchen, or "little cats." In Hans Andersen's "Story of the Vear," which is one of the most charming word-pictures I think I know, "Fairy Andersen " says, "It was a beautiful spring, but the willow-trees wore woollen mittens over their blossoms, they were exceedingly careful, and that is tiresome." "Mittens" is an old Scots term for 


\section{Stray Leaves from a Border Garden}

woollen gloves, and woollen gloves without fingers are called "Doddie mittens."

February 14.-There is a quaint old saying :

Crocus blows before the shrine

At vernal dawn of St. Valentine.

I came across the following delightful statement the other day. If you lay two bay leaves wet with rosewater on your pillow, and repeat on going to bed the following charm,

Good Valentine, be good to me,

In dream let me my true love see,

you are sure to see the face of your future husband in a dream that night.

This is curious, as St. Valentine was not supposed to entertain a high opinion of women, and in his day was far from being a patron of lovers. People don't keep St. Valentine as they used to do; one never sees Valentines much now, no one seems to send them.

In Pepys' "Diary" there is amusing mention of Valentines, and also in Sir Walter Scott's " Fair Maid of Perth."

The name February is from Februalia, the time when the Romans made sacrifices of expiation. The Saxons offered cakes to the sun and called it Sol monath, and also Sproutkale. It was also called the "mire month"; well named, I think.

March I 3.- How curious it is to wake up to a white world. I suspected snow when I woke, there was sucha strange white light coming through the gap in the window-curtains, which seems inevitable unless one has one entire curtain to cover all the window. There is also an odd stillness that can be felt combined with warmth comparative after the piercing cold of the bitter wind which seems invariably to precede snow. It must have snowed heavily and steadily all through the night; it is lying thick on all the branches of the bare trees and in white sheet-like expanse all over the fields and in drifts in the lanes. The sky is a uniform grey-white and the Cheviots are invisible. Every laurel and holly leaf bears a separate burden of snow, and a dead hemlock seed 


\section{Martinmas to Ladyday}

spire or kecksie was simply lovely with its tiny white tutts on every branchlet, while especially pretty were the bushes of syringa, like feathers.

The birds are hopping about, looking puffed and bored. A plateful of scraps put out by the door was soon surrounded, a robin, of course, leading the way with inquisitive boldness. I spent ever so long yesterday at the window watching the birds. They sat on the area railing, with beady eyes fixed on the window-sill. After I had put crumbs on it they came, at first shyly, then more boldly, dear feathered beggars; it was curious how selfish they were. A thrush was eating and another thrush came, and he flew at the newcomer and drove him away. Meantime a poor little wretch of a ragged tiny tit, a veritable woodland tramp to look at, humbly crept up and snatched a hurried bite. Two sparrows fought so furiously over a large crumb they lost their balance and fell together in the snow, which sobered them. Altogether my would-be pensioners are most amusing and most varied. I had visits from robins, thrushes, starlings, blackbirds, tits, a green lintie, a chaffinch, and of course sparrows. Indeed, I was told, if I continued to offer hospitality, I should have all the birds of the Borderland a-begging. It is really the victory of strength and impudence. But, alas, the house-cat sometimes brings about a tragedy: as one time, Puss, who thought such a congress of birds interesting, came round the corner and darted on a robin, coolly bringing it to me as an offering; but, seeing he was not going to be praised, Puss retired and disposed of his victim under the laurels. Among the regular pensioners I noticed a most wretchedlooking blackbird, whose head, being almost entirely bald gives him a most curiously aged look.

John says he is afflicted with a disease that comes of over indulgence in beechmast, reckoned a delicacy by blackbirds (and by some children too)! Poor Mr. Blackbird! I heard of a white blackbird being seen somewhere near here lately. I should like to have seen it. There is, or was, some French château held by the presentation, once 


\section{Stray Leaves from a Border Garden}

a year, of a white blackbird by the owner to his feudal superior.

March 14.-The Romans called this month after the god of war, Mars: was it because of the warring of the winds? The Anglo-Saxons called it the wild or stormy month, Hlyd monath, and also the spring month, Lenct monath. Perhaps that is the reason why the daffodil used to be called Lent lily.

March 20.-I found on a sheltered bank to-day in the "plantin" (plantation) some tiny blue stars of periwinkle; "sorcerer's violets" is the quaint old name for them, also "pervinkle," from Pervincere, to overcome, because it is not vanquished by the cold of the winter. Pervinca is the Portuguese name. I have also discovered a colony of winter heliotrope or sweet white coltsfoot (Petasites vulgaris) growing on the bank above the snowdrops. I believe it is rather capricious in its choice of a haunt. I am glad it likes to live with me. "Son afore the father" is the old Scotch name for it.

How beautiful are the Snowdrops, a perfect sheet of white, nodding their drooping heads in the wind and literally scenting the air! My correspondents must think me mad. I can write no letter without singing the praises of my "White Babies," as Boy calls them-Schneetropfen or Schneeglöckchen, as the Germans call them: little snowbells. In Sussex it is said to be unlucky to bring the first snowdrop into the house, as it is thought like a corpse in a shroud. Here is a little snowdrop song I wrote in the book called "Ye Booke of Ye Baby" I have gathered of Rhymes and Jingles for Boy. How he loves to be sung to! When it grows too dark to see to play, a tired wee laddie comes creeping to mother's knee, and the fire is poked to give us "Queen's light."

"Sing, mammy":

Dark, dark, dark, Down in the soft warm earth Naked Baby sleep cosily, Jack Frost can't catch 'ee! 


\section{Martinmas to Ladyday}

Sun, sun shine,

Warm on White Baby's bed,

Greencoat Baby come up see

Jack Frost won't catch 'ee!

Peep, peep, peep,

Out of dry leaves and moss

White Babies run all over the brae, Jack Frost he's gone away!

March 23.-In spite of the fall of snow, which lay two whole days, our flowers and buds are still coming on. The snow has been gone some little time; it fell on the thirteenth, and it does not seem to have done much harm. The way in which the snowwreaths linger in sheltered corners reminds me of a pretty Russian legend I am fond of, the Story of Snygurka:

Poor and lonely, a childless life

A moujik led with his gentle wife,

Round other men's boards fair children flocked,

Other men's wives full cradles rocked.

Only, alas, to poor Ivan's home

No little lad or lass had come ;

Alone to the field or wood he went,

Alone the long hours poor Masha spent.

Somewhat apart their small izbà stood

Upon the edge of a great pinewood,

The village children many a day

In a joyous troop came there to play.

And when once they made a Snow child,

The childless couple look'd and smiled,

And said, when the children homeward went,

"With all God sends should we be content.

Let us no more repine and moan,

But take the Snow child to be our own."

Softly a tear from Masha's eyes

Dropt down, and oh! the glad surprise!

The little snow figure smiled and stirred,

The snowflakes fell, as from a bird

New hatched, the eggshell falls away,

A little girl stood there fair as May!

With hair as gold as the fresh flax flowers,

Eyes blue as the sky after summer showers, 


\section{Stray Leaves from a Border Garden}

Her skin as white as new fallen snow, But a flower face paler than lilies e'er show.

The village children many a day

With sweet Snygurka came to play ;

She was as a sunbeam in the life

Of the poor old moujik and his wife.

Winter ended, the Spring sun smiled On the earth, but, alas, the fair Snow child Pined, as the sunshine waxed warm and strong, And hid away from the childish throng.

About the fields the children sing :

"How did you come to us, sweet Spring ?

Didst come a-riding harrow or plough ?"

But Snygurka will not play with them now.

As the Winter's snowwreaths failed, Snygurka daily pined and paled, And Masha feared the Evil Eye Had doomed her little Love to die.

The last of Winter's snow had fled; Winter, grim conqueror, lay dead, The brooks and streams ran free and fleet, 'Twas easy to track Spring's scented feet.

The nightingale and all birds sang, Thro' all the world Spring's joybells rang, The gloom of Winter had passed away, Yet Snygurka became more sad each day.

She loved to play in the chilling shower, Or under the trees-a timid flower, From the sun in sheltered nook would hide By the green willows, by the brookside.

The feast of St. John was now at hand, The cornfields were golden throughout the land, In the woods the children spent many hours Playing and weaving wreaths of flowers.

As the sun set they made a fire, Danced and sang round the glowing pyre, Crying: "Snygurka, come, do the same." But only a sigh in answer came.

For many a day, by wood and wild, Men sought in vain for the gentle child. With aching heart poor Masha cried : "Surely Snygurka has not died!" 


\section{Martinmas to Ladyday}

But, alas, nor Ivan nor Masha heard

What was only known to the wild woodbird,

How, when the fire waxed strong and high,

A small grey mist arose to the sky.

Thus, at the eve of the summer's day,

Snygurka, the Snow child, passed away.

And long were the hearts that loved her sore,

For the well-beloved who was seen no more.

March 24.-The roses continue to bud under my very eyes. In a few days both the red and white or rather cream-coloured ribes will be full-flowered. I wonder who was the flower-loving soul who with such a liberal hand seems to have scattered bulbs about these banks. I see daffodils, or crowbells, as some people call them, uprising their grey sheaves and gold bells in all sorts of out-of-theway nooks, among the laurels and mahonia under the beeches. I like the meaning of daffodils in Flower Language : "Regard" ; Lent Roses, and Saffron Lillies are nice old names for them. I shall try to leave a flower mark also behind me. Already I have put in sweetbriars and columbines (culverworts or doveplants) and narcissus in the plantation, and inserted roots of arabis and hoped the insatiable rabbits would let them grow! But the rabbits here are models of decorum compared to some I have heard of in a place in Kent, where they not only ate up everything in the garden, but were actually found frisking in the hall, and sitting in the drawing-room chairs! "Brer Cottontail" is so pretty, I think, especially when he is young, a round brown ball of fur. Yet it is a very unwilling admiration one accords when one sees, as I didto-day from the window, a tiny brown marauder calmly "taking his tea" off one of the topmost shoots of a newly planted rose in what I proudly call the Rose-garden, a small enclosed terrace where I am trying to acclimatise some roses from the Orlêanais.

The little sinner actually stood on tiptoe to reach the topmost sprout! A "Jameson's Raid" at once took place. Father and daughters rushed outside, mother and son 


\section{Stray Leaves from a Border Garden}

"hurroo'd" them on to victory from the window above. Baby Cottontail looked wildly round. Wire enclosed the Paradise on all sides, except one. Here was a drop down amongst laurels to unknown depths, but better this than to be caught. He leaped wildly into the laurels and escaped! At least, never was his little body found.

How attentive, too, are the birds to my softly greening flower-beds, where pinks and iris and tulips are to look beautiful some day in the midst of the square grass lawn! A bold blackbird continued his grubbing under my very nose, flirting the freshly turned earth calmly over the grass

Was he eating seeds, I wonder, or worms?

Worms let us hope. The mice are said in this garden to be hard upon crocuses. I have heard this is so, most particularly in Berwickshire and East Lothian. I have not dared to plant any in the open, but I have several pretty window-boxes gay with them and earthen vases standing in the rose-garden, large white crocuses with golden pistils, purple, and tiny purple and white striped; these are cuplike; then I have also quaint little brown star-shaped ones lined with yellow ; "cloth of gold," I think, is their name. But, on the whole, I think I like the oldfashioned golden cups best. I saw a tuft of these last in flower a few days ago in an empty vegetable-bed in the kitchen-garden, and on inquiry of Gardener how it was they came there, he said: "They rats had nae doot ta'ed the bulb awa'!" I should have liked to have seen Herr Rat carrying his bulb home. How disgusted he must have been on reaching his abode to find he had dropped his loot by the way! It is curious, considering how pretty the crocus is, how little celebrated it seems to be in poetry. Hannah F. Gould, the American, however, has a pretty little poem about the crocus, too little known I think. I wish I knew what to think about moles. The other day, when walking with Boy in the tiny railed-in crescent of grass I call the lily garden (because of a bed of these dear things in the centre), we saw several molehills. The 


\section{Martinmas to Ladyday}

beautifully sifted earth I hastily began to remove to a border.

"There it will be useful," I said ; "here it is a mistake, on the grass." "What a pity! " said Wise Four-year old. "Mr. Mole did not know where to put it. I think we must tell him. Of course he did not see where he was putting it, as he is blind!" In Gloucestershire molehills were called " nootie stumps." I wonder if this word has anything to do with the Shetland word noup, meaning a roundheaded eminence, or with the Icelandic knaus, a lump of earth, or the Anglo-Saxon knoop or cnoep, meaning a button or round knob, which survives here in the Lothians as knoost, meaning a large lump. There was an old belief once upon a time, as the fairy tales say, that molehillocks were for the lambs to rest upon. But though I have seen many lambs of all sizes in the field with the molehills, never yet have I seen a lamb using a hill as a pillow or seat, or the "moudies" asking them to sit down! In Fife they are called "mowdie hoops." Hoop means a " heap" in old Teutonic. Some people say the dear "moudies" eat wireworms, and therefore should not be destroyed, but the gardeners and gamekeepers say "vermin." What a holocaust of the poor little things I saw in a field the other day; the little black velvet bodies with tiny outspread hands looked so pathetic! I knew a lady who had a moleskin jacket, but though very soft it was not very pretty, as the unavoidable joins were too obvious.

I found a pure white periwinkle the other day among the blue ones-Vinca minor alba. Like most albinos, more curious than pretty. Long ago the periwinkle used to be called the "ivy of the ground." A rather nice term, I think. Vinca minor is, no doubt, Chaucer's " fresh pervincke rich of hew." Nothing equals the blue stars, to my mind. I want to try and introduce here the large grey periwinkle (Vinca media), which grows so thickly in damp shady corners near old ruins in the South of France, and blows at Christmastide.

- In Tuscany, periwinkles are called " death flowers," being 


\section{Stray Leaves from a Border Garden}

grown on graves. They are sometimes planted on graves in England and Scotland, though the practice of planting flowers on graves does not seem so common in Scotland as in England. There is a pretty variegated-leafed periwinkle. I must get it ; also an old-fashioned Vinca minor with a tiny mauve flower, not, I think, very common.

There is also a double Vinca minor, rather pretty. Like my namesake, Mary Queen of Scots, I should like to leave a flowery souvenir behind me. I heard the other day that the French sorrel still grows in the ruined precincts of Craigmillar Castle, where she used to love to live quietly. Poor thing! she is said to have been very fond of gardening. It is curious to think of her, with her stormy life, in connection with such a quiet and tranquil pursuit, wandering up and down amongst her flowers or embroidering wonderful floral patterns!

There is a tradition that, when imprisoned at Chatsworth, Queen Mary tried to while away the weary hours by planting a flower-garden within a dreary walled enclosure shaded by a couple of yews and a sycamore, and called Queen Mary's Bower. Whether any trace of it still remains I do not know. But, indeed, one can have untranquil moments in a garden, as when with budding roses there is fear of frost; and as this week, when the heavyfooted woodcutters have been tramping around with designs upon the tall beeches, and crushing the starting Primroses and peeping Swallow-worts. The Golden Mahonia is beginning to bud. I used to deem this glossy-leaved shrub only fit for villas, for suburban abodes, on either side of trim approaches, up which rolled the carriages of Madame, late ironmongeress, or Monsieur, retired baker or butcher, on country joys intent. But now that I see it amid other shrubs on a wild bank in the dear plantation I take back my strictures, and will love its shiny stiff leaves and trim pre-eminently tidy flowers. I was reading the other day Mrs. Ewing's pretty little sketch called " Mary's Meadow," in which she tries to interest children in old John Parkinson's idea of every one trying to acclimatise flowers in odd 


\section{Martinmas to Ladyday}

corners. A pretty enough idea, but, in the present hurried swing of the world's daily life, will many folk find time to follow up this idea?

In a newer book, called " The Daybook of Bethia Hardacre," Ella Fuller Maitland touches rather on the same thought, dwelling more especially on the odd and varied names of flowers. I have often thought how curious it is to see how sometimes they are just translations of one another: for instance, the pretty flower called in England Meadow-sweet (Spiraca Ulmaria) is here Queen of the Meadow ; in Spain, Reyna del Prado; in Italy, Regina degli Prati ; in Portugal, Rainha dos Prados; in France, Reine des Près; and in Germany, Wiesen Königin. Bridewort is another pretty name for it. Crane's Bill is Bec de Grue in France. It is also curious to note how sometimes the old names keep green the memory of those who introduced them into English gardens: as Camellia, derived from Kamel, the German botanist; Dahlia, from Dahl, the Swede ; and Fuchsia, from Fuchs, the Bavarian herbalist. I like, too, the story of the fuchsia's first arrival in England: the sailor bringing home a cutting from Chili to his wife. It is also very interesting to supply vacuums in one's garden from one's friends' domains ; the sight afterwards of the flower brings pleasant memories. I found on arrival here that there was only one tuft of Lily of the ValleyMay Lilly, or Lily Constancy,as is the delightful old nameso I begged and have now received a sturdy clump from a kindly neighbour, and another clump from Devonshire, from an old garden where I spent many pleasant hours. That garden is now, alas, no more; it passed into the hands of a jerry-builder, who swept away the ancient lily bed to put a smart new greenhouse in its place to attract tenants to the old house. Neither were there Violets. These I also procured, also Hepaticas, sometimes called Herb Trinity, Liverwort, red, blue, and white, also called Poor Johnnies, without which no garden can be, I think, complete. Then from Devon some roots of a somewhat dwarf Daffodil, which brings back to me a brown trout-stream, and 


\section{Stray Leaves from a Border Garden}

an old bridge where, in the low copsewood on the damp banks, Daffodils flourished so freely and beautifully. Close by I remember was a quaint little red-brick Baptist chapel, built over the stream, so that the humble worshippers could conveniently carry out their rite of immersion. From yet another friend in Devon I got Daylilies (Hemerocallis), a souvenir of as pretty a garden as one would wish to see : an old quarry turned by cunning direction of Nature's hand, not by forcing it, into a lovely natural-looking collection of flowers at all seasons; Tulips and Narcissi in the grassy banks, and Daylilies with their orange flags making dull corners beautiful with their unchecked luxuriance. Then from France I have the big grey-eyed Periwinkle of Provence, and Anemones, which I hope will condescend to grow in this cold and damp northern clime. So will each flower bring its souvenir.

There is a charming peculiarity about the begging of gardeners. You know that the recipient does not leave the giver the poorer for his generosity; on the contrary, there are very few plants that are not the better for being relieved of their offspring. So I have no scruple in being a Border raider. 


\section{CHAPTER II}

\section{LADYDAY TO WHITSUNDAY}

March 25.-Lady Day, sometimes called Marymas. Although a house term in England, it is not so in Scotland, the house-flittings usually taking place at the end of May, which is the term of Whitsunday, and has nothing to do with the Whitsuntide of the English Church. Although probably it equally arose out of the White Sunday, when in the earlyChurch times newly baptized persons were supposed to go to church in white garments, yet now in Presbyterian Scotland Whitsunday Term is nothing else but a term, it is no longer a Church festival, and seems only to be a festival with the rent collector. It is possible also that Whitsunday may be a corruption of Witan Sunday, as Witanagemote, the Anglo-Saxon for Wisdom Sunday, meant "meeting of the wise." They called this month sometimes Rhed monath, from their goddess Rheda, whose feast-day fell at this time; Rede meant "council," and this was the time of year at which warlike expeditions were debated by the Saxons. Rede is an old Scotch word and has many meanings-i.e., to counsel, to settle, \&c. It still survives with this last meaning, I believe, in Pennsylvania beyond the sea. Boy and I saw from the window to-day the infant marauder among our young roses. Quoth Boy : "It's a pity Master Rabbit's parents did not tell him it was not polite to go in a garden and eat other people's roses." I was then treated to a long and elaborate dissertation upon the advisability of laying a trap for the intruder in the shape of a pitfall, evidently a reminiscence of some story about lions 


\section{Stray Leaves from a Border Garden}

and confusion in the small man's mind. The following day a springe was set and the hole in the hedge blockaded, and no more has been seen of Master Rabbit-at least nothing authentic. There is a rumour he was seen on the farther side of the wire-netting, sadly peeping in at the paradise he could not enter, a little Woodland Peri at the gates.

April I.- I hope Spring is not going to make an Aprilfool of the too confiding buds and leaves, and send Jack Frost later on to nip them ; they are all hurrying out to greet her : the whilome broomlike syringas are now covered with green tufts and the lilac is promising early bud (Laylock, Lilyoak, Pipe-tree, what quaint names this old favourite has, to be sure !). I watch daily a certain slim young poplar, as branch after branch seems to cover in an instant with tufts of the loveliest golden-green leaflets. I am rather partial to poplars. I always liked the long, white, far-stretching, straight as a die French roads, bordered with rows of tall poplars-l'arbre de Liberté as the French sometimes call the peuplier. Bitterweed is an old Border name for the poplar, on account of its bitter bark, and there is an old saying, "Oak, ash and elm-tree, the laird can hang for a' three. But fir, saugh and bitterweed, the laird may flyte but make naething be 'et." Now the old grey bushes of ribes are fast covering with their quaint grapelike bunches of red or white flowerets; Siberian Currant is its other name, and perhaps the prettiest and most quaint. What a contrast the quiet homely avenues of these northern homes must be to any of these currant-trees who may chance to cherish any recollection of their native Siberian steppes, snow covered, wind swept and lonely to a degree! By the way, our unromantic and homely black currant also hails from Siberia, I believe.

\section{THE COMING OF SPRING}

Yonder he comes, across the snowy plains,

The darling Prince, by Nature look'd for long,

Circled by breezes, and soft April rains,

Upon the air the echo of his song 


\section{Ladyday to Whitsunday}

Rises and falls, the early primrose peeps

From sheltered nooks, for if indeed 'tis he,

The banks and braes and all the woodland deeps

Look for her stars to deck their braverie.

Before him, Winter fainting, falls and flies,

And Spring's retainers whisper $\mathrm{He}$ is dead !

Triumphant onward Herald Swallow hies,

Proclaiming Spring abroad in Winter's stead.

The banners of the nut-tree are unfurled ;

The shooting grasses haste their Prince to greet,

While Pussy Willow stealthily uncurled

Lays all her silvery softness at his feet;

The courtier butterflies, who bear his train,

Spy out the country on light idle wing,

Woo the shy wildflower, swear to come again,

And promise boldly many a fairy ring.

The unbound brooks run singing thro' the woods,

Forgetful of their hardships that have been ;

The little buds discard their winter hoods,

And burst out gayly in their brightest green.

Now comes the Cuckoo, gleeman of the lane,

A vagabond without a household care,

The wildwood minstrel and the young birds' bane,

No house nor family cares has he,

Who flits from home to home in each green tree.

Mavis and Merle Spring's praises vying sing,

And vestal snowdrops now start forth to meet

The gay young Prince, the long-expected Spring,

Before whose face the snowflakes beat retreat.

The passing clouds leave blue the archèd skies

A canopy for Spring, who reigns at last.

Upon the earth he beams with sunny eyes.

Fair captive Nature, freed at last, with smiles,

Doth greet her gallant with a radiant look,

With wayward kisses and sweet winsome wiles.

April 4.-The woodcutters are gone, but the carters who succeeded them are still at work. It is rather nice to watch them, the big gentle horses understand their work so well, and seem to take quite an intelligent interest in "trailing" the prostrate tree-trunks down the bank on to the green haugh below, where they lie like wounded warriors ready for the cart and departure. The Ojibway Indians had a quaint fancy that trees had souls, and did not like to cut them down lest they should hear them lament. I remember hearing in Jamaica that the silk cotton-trees (Bombax ceiba) are known as Jumbi trees, and any one cutting them down 


\section{Stray Leaves from a Border Garden}

incurred the anger of the Jumbi, or evil spirit. One is tempted to wish this persuasion more widely prevailed when one sees the wholesale clearance of trees made in some places. An unwise proceeding too, for there is a persuasion among some scientific arboriculturists that the change for the worse of the climate of the Riviera is due to wholesale deforesting. I have at last got to know that "haugh " means a grass flat by a river. Although written " haugh" it is pronounced something like "haw." In Northumberland, though written " haugh," it is pronounced "haaf." "Haugh" is said to come from the Norse, and in Icelandic there is a word hagi, meaning "pasture." The Icelandic is said to be the language extant resembling most nearly the language of the old Vikings, who have left their mark in so many places. There seem to be a good many local words hereabouts of Scandinavian root, and I think I will note them (see Glossary) whenever I come across them, to my knowledge. This interesting subject is cleverly handled in a book by Professor Veitch, called "History and Poetry of the Scottish Border," well worth reading. One of the wood-carters' horses, by name Jimmy, has been at wood-hauling in the same hands "ever sin" he was a little yen" (one; Danish, een) says his master, who seems both proud and fond of him, and, though shouting rough-sounding directions very loudly, never fails to pat the good beast whenever he has pulled to the desired spot some troublesome long bole. "I like to see how everything is done," says Boy, standing with his feet far apart, and his red cap well on the back of his golden head, and the stalwart carter smiles approvingly; such a laird would commend himself to the keen Scot's mind, no doubt. The quaint old-fashioned auriculas are beginning to be plentiful now. "Dusty millers" the Scotch call them, and indeed one is very dusty after picking a posy of the dear little dowdy brown blooms, whose delicious smell makes one quite forget and forgive their plainness. Bear's-foot and Primrose Bear's-ear are old-time names for these, probably translated from the French oreille d'ours or the Italian orechio d'orso. Bear's-foot is also applied to the 


\section{Ladyday to Whitsunday}

Stinking Hellebore. In Yorkshire--I think in the Holdernesse district_auriculas go by the odd name of Wrecklesses, but what it means I do not know, nor even if I spell it rightly. Alchemilla, or Lady's Mantle is also sometimes called Bear'sfoot; Padelion is a curious old English name for this. It is curious that in the Greek, Latin, Italian, and Spanish, Lion'sfoot is its name, while in French, German, and Dutch it has both names of Lion's-foot and Ladies' Mantle, a corruption of Our Lady's Mantle being one of the many plants associated with the Mother of our Lord.

It is rather nice the way in which the Bear's-ears, and indeed all the flowers in this old kitchen-garden, are hailfellow-well-met with the vegetables. I suppose it is owing to the old fancy that plants affected each other for good and evil, and nice plants gave of their virtues to their neighbours, and were in consequence often planted side by side. I have heard that in America, in Virginia, the oldfashioned way of planting vegetables with flower-borders round them in enclosed gardens has died out, and the present American gardener prefers flowers and vegetables grown quite apart. I don't think it can be so pretty. But there is nothing new under the sun. This would seem to have been the custom in the days of Henri IV. of France, since the Seigneur du Pradel, called the "Father of Agriculture," describes kitchen-gardens, called le potager, as apart from le bouquetier, for flowers, le médecinal for the herbalist's benefit, the old-time Physick Garden, and le fruictier or orchard.

To-day Boy and I saw a tiny crimson spider. I like the old Scotch name for a spider-Ettercap. It seems to be quite gone out of use, at least here. In Jamieson's Dictionary I find a cross-grained, evil-disposed person used to be called an Ettercap or Capper. It is curious the derivation, from the Anglo-Saxon Attercappe, meaning "cupful of venom." Leyden, the old Border poet, wrote a curious poem called "The Lay of the Ettercap," in which he makes allusion to Ritson, the antiquary, as 


\section{Stray Leaves from a Border Garden}

That dwarfe is a fell Ettercap,

And liven aye on nettlesap,

And hath none other fode.

Ritson was a vegetarian, and had written spitefully about Leyden's friend, George Ellis, of " Early Metrical Romance" fame, and Leyden resented this, and while abusing Ritson thus, gives in this fragment a pleasant description of my kinsman as that "Squyere hizt Ellis with his eyen grey as glasse, and his Fairy Dame"-Mrs. Ellis being a very little woman. Here the village children greet a red spider with this verse :

\section{Redcoat, redcoat, fly away,}

Gie us to-morrow a bonny die.

"A bonny die" is a little present.

In Devon there is a saying, a red spider is a money spider, and brings wealth to some one; the person who first sees it, I suppose. I told this to a little Scots lassie, and she pondered thereon awhile, and then remembered solemnly how it was certainly after seeing a red spider one day a luck penny had come her way! I need scarcely add she had further cause to believe in it. There is a dislike to kill a spider in Scotland, especially on the part of a Bruce, for the sake of the good turn done to The Bruce by a spider.

How pretty the Italian name for gossamer spider's web isFilamenti di S. Maria! The Scotch term is "mooseweb" or " mouseweb," from the old Teutonic mos, meaning moisture. In the West Indies spiders bear a bad character, yet it is deemed unlucky to kill them, especially the big ones called Anansi. "Anansi " means "evil spirit," and I think comes from a West African term ananisem, to spin. Spiders used to be put into old-time medicines : a spider in a nutshell hung round the neck was deemed a cure for fever. Longfellow alludes to this as a fancy among the Acadian peasantry. My old Herbal is full of quaint recipes against the "poysonous bitings of Spideres"; indeed, to read this old Queen Anne book, one would imagine English spiders were 


\section{Ladyday to Whitsunday}

as venomous as some of their tropical cousins; yet who can forget the sad fate of 'Tom Thumb, slain by the spider's "poysonous breath?"

April ro.-This is the budding or opening month, Aprilio. The Saxons called it Oster monath, as it was the time of the feast-day of their goddess Eastre, whose name has clung to our Church festival of Easter.

April I 7.-We had a hail-shower the other day, but to our joy it did not lie long. The distant Cheviots looked to-day, with the stray patches of white, just as though the wandering shepherds had been hanging out their sarks to dry on the whin bushes. "Broom thorney" was a quaint old English name, and an old Scots name was "Carline spurs." In this neighbourhood "carline" used to mean a witch as well as an old woman. It is from the Anglo-Saxon keorl, Icelandic karl, which still survives in English as "churl." The addition of In made these words feminine. A Tom-cat used to be called a "karl-cat," which, I think, is rather nice. The kitchen-garden is quite gay now with its tufts of yellow narcissus- "eggs and bacon "some people call them, a name which has also been given to the Crow-toe and to the little wild Toadflax. There are also budding wallflowers. How much prettier was their old-time name of Cherisaunce, meaning "comfort," in Spenser's day and Chaucer's! Blue forget-me-nots, white globe anemones are now flowering, and Solomon's Seal (Sealwort), so called, it is said, because the markings on the root resemble a Solomon's Seal, as the Arabs called a star with six points, often mentioned in Eastern fairy tales, especially the "Arabian Nights' Entertainments." It was also called Our Lady's Signet, and Ladders to Heaven, and David's Harp. There was an instrument called a "gliew" in Anglo-Saxon days which was shaped like the Sealwort, with a lot of little bells. This is sometimes drawn in old monkish books as the harp David played before Saul.

The Delphinium and Monk's-hood clumps are rampant with green feathers, but as yet no flowers. I must try and get the Yellow Helmet flower. It is curious Monk's-hood 


\section{Stray Leaves from a Border Garden}

was its name as far back as Shakespeare's days. If I plant new plants in the garden in autumn I forget about them during the winter, and they come as a surprise to me in the spring and summer. Pleasant but sometimes inconvenient. The pears and the plums are covered with pretty white artificial-looking bloom. Boy was eager to present me with ready-made bridal bouquets, and had to learn that he must not pick off the blossom lest he lack fruit later on. The wild violets, purple and white, are beginning to show now, and tiny white potentillas, the "fairies' strawberries," and blue-flowered comfrey. The trout-river is very low now, and the flags are beginning to show their green shafts by the bank. Here they call them "segs" or "sag," and there is a tradition that it was amongst such Moses was hidden. Segge or Saeg, "little sword," is the old Anglo-Saxon name for the flag (Iris psendacorus). It is curious there is yet a verb in New England to "sag," meaning to "droop down," which is said of dress skirts, and also applied to thatched roofs. It is certainly true that many words now obsolete hereabouts, or nearly so, have survived beyond the Atlantic. I remember words and expressions in Jamaica which I was surprised to meet in common parlance here. On the haugh by the water the Swallow-wort, or Celandine's Golden Stars_Earthstars, as somebody prettily calls them-are rampant. Eclaire is the French name. "They are the fairies' gold pieces," I tell Boy. "What do the fairies do when there are no more flowers on the plants?" asks the practical youthful Scot. An unanswerable question. I wonder there are not more songs in praise of Celandine. I only know of Wordsworth's pretty praise. Gerarde notes a pretty fancy that it is called Swallow-wort because the mother swallow uses it to cure any imperfection in her nestlings' sight. Dr. Schallern (1790) has left on record he used Celandine successfully in many diseases of the eye. But nowadays its virtues, if virtue there be, are forgotten, and it is only remembered that its juice is poisonous. It is also said to be called Swallow-wort because it blooms when the swallow comes 


\section{Ladyday to Whitsunday}

(which it don't here), and withers when she goes. To-day we had some cowslip roots sent us from the meadows near Weymouth, where they grow in abundance, some actually in bud, though it is only April I8! I wonder how they will thrive transplanted to rich garden soil after their lush meadowland. They will be quite travelled monkeys to their next-door neighbours in the border, some humble brown Bear's-ears, which have been in the same place for years. A nice old name for the cowslip is Our Lady's Keys, and they are called Ladies' Fingers in Fife, and Fairy Caps, I believe, in Lincolnshire. I like the German name of Himmelschlüsselchen-"Heaven's little keys"-and the legend that one day, when St. Peter was told people were trying to get into heaven by a back way, so as not to have to enter by the great locked gate he was in charge of, he was so distressed he dropped his keys. They fell on the earth, and where the bunch fell a posy of cowslips appeared. Parkinson, among the variety of cowslips in Queen Henrietta Maria's garden, mentions one called the Franticke, or Foolish Cowslip, or Jackanapes on Horseback. Among the many uses formerly made of cowslips, it seems a balsam, "sovereigne for green wounds," was concocted long ago, of which it is asserted by my Queen Anne Herbalist "that 'tis a medicament which every good Country Man ought to keep in his houfe." Primrose Day will shortly be here. I feel deeply thankful the favourite political deity of the Scots is Gladstone; we may hope to keep our primrose banks unrifled by the primrose-hunting Tory. Still, I think I will mount guard over my beloved "lilye flowers," lest they be reft away: May's Pinks, as they used to be called. I heard the other day of a decoction called "Primrose Vinegar." I must try and find out how it is made and what it is good for.

The birds are preparing their nests now. The sparrows and others who elected to build on the house among the ivy must have been rather disturbed in their operations a few days ago, when Gardener clipped the ivy, or, as he said, "switched" it, leaving the house woefully bare and naked- 


\section{Stray Leaves from a Border Garden}

looking. But I see the building work now going on as fast as ever, hurried small birds perpetually on the wing to and fro with straws and feathers. I believe the widespread belief ivy is bad for walls if allowed to grow on them is incorrect; at least, if the wall be strong and well-builded, ivy is useful, as its roots suck up any moisture, and thus keep the walls dry. On thinly built "jerry" walls, however, the moisture can soak through, and then the ivy tangle as a harbour for snow and raindrops is a bad friend to the building. I was told the other day that ivy such as ours (hedera Helix) is not known wild either in Australia or in America. Old trees covered with ivy, and ivy growing in wide beds on the ground as it does here, always excite the admiration of Americans. It is strange that ivy is first cousin, so to speak, to the tropical aralias. Its name seems to come from the Celtic word $i w$, meaning green, or the Anglo-Saxon ifig. Hedera is said to be from the Keltic also, from Hedera, a cord. In Italian it is Edera; in Portuguese, Yera; and in Spanish, Yedra. But the yew and the ivy seem to have been much muddled up in old days as regards names.

Ivy was dedicated to Bacchus in old days, and there was an opinion amongst the ancients that it was an antidote to drunkenness, which may be the reason why an ivybush was often hung over the door of a Tavern; and this also may be the origin of the talk about "owls in ivybushes," and "good wine needs no bush." Wine-cups were sometimes made of ivywood, and I have heard that the wood called " bentwood," out of which little chairs are sometimes made, is said to beivytree. Ivy is called " bentwood" here sometimes. Ivy berries were said to have been useful as a powder in the Great Plague of London, but I do not think they are much used now in medicine. The birds seem to eat them when there are no more haws to be had. A pair of pretty grey woodpigeons have chosen a tall beech-tree covered with ivy, and are to be seen sitting at eventide in sweet converse together on a bough, presumably discussing their household arrangements. Another pair haunt a fir-tree in the avenue, and 


\section{Ladyday to Whitsunday}

coo continuously. The growths in the birch-trees called "birk knots" or "Witch knots" are thought by some people to be the nests of the cushat, cuschette, or cushie doo. This name comes from the Anglo-Saxon cusceote. "Birk" is from the Anglo-Saxon byrc; Danish, birk; Icelandic and Swedish, biörk. It has also been derived back to a Hindoo word birchk, a tree. It was also called "bark-tree," because its bark was used in many different ways. The robins are delightfully tame and hop quite close to any one at work in the garden. How is it they should be called "redbreasts" when the colour of their breasts is really orange? Physals Alkengi, the ,plant that has such pretty orange-coloured seed-vessels like Chinese lanterns (whence it is sometimes called the "lantern plant"), is also sometimes the "redbreast plant." I pursued it through several catalogues under this name, thinking it was something new, and was rather disappointed to find it was just the Winter Cherry I knew quite well. A handsome larger variety has lately been introduced from Japan. There is, I am glad to say, a feeling in Scotland against taking robins' nests, as evinced by the old nursery rhyme:

The Laverock and the Lintie, the Robin and the Wren,

If ye harry their nests ye'll never thrive again;

while another version declares that

Robinet and Jenny Wren

Are God Almighty's Cock and Hen.

Him that harries their nest

Never shall his soul have rest.

I think a pair of robins are building in the laurels by the house.

I like the old legend of the Robin, how he tried to pull out the nails when Christ was crucified, and his breast became bloodstained in consequence. How bold the sparrows are; more audacious, I think, even than the robins! A sparrow comes every day to the nursery window, where Boy puts crumbs in the hard weather, and out of which window I fancy Nurse still shakes the breakfast-cloth. He taps at the glass with apparent indignation if he does not find crumbs, 


\section{Stray Leaves from a Border Garden}

evidently greatly to the anger of Boy's smart Canary-bird "Sweet," swinging within in a gorgeous gilt cage. The little aristocrat flings himself against his golden bars and pours forth a perfect flood of vituperative song at the intruding vagrant. The Bird Cherries (Scottice, gean; French, guigne) are beginning to show their light graceful tufts of white flowers in the lane, so pretty I do not wonder the festivalloving little Japanese have a special merrymaking at cherryblossom time. I long to do the same. They seem to cultivate cherry-trees for the flowers, and call the cherry the Queen of Flowersand make small account of the fruit. The cherry-tree is one of the many floral beauties dedicated in old days to the Virgin Mary, and there is a quaint old Christmas carol known as the Cherry Tree Carol.

To-day Boy and I gathered'a lovely bunch of cherry bloom and sweetbriar-Chaucer's Eglantere-which grows so freely by so many of the quiet roadsides hereabouts, and sundry small branches of the larch becoming daily more laden with green tasselkins. Sweetbriar, I heard the other day, is delightfully called the " missionary plant" by the Maoris in New Zealand, as it is said to have been introduced there by a homesick missionary's wife. It is now almost a weed there. An old Scotch name for the sweetbriar is "hepthorne," the fruit being heps or hips. There is a promise of broom also, and budding hawthorn, pink and white, down by the river and by the brae. "Mony Hawes, Mony Snawes," is a common saying here. Bacon writes: "It is an observation amongst country people that years of store of Hawes and Hips do commonly portend cold weather, and they ascribe to God's providence that as the Scripture saith reacheth even to the falling of a sparrow, and much more is like to reach to the preservation of birds in such season." Burns seems to have been very fond of hawthorns, he mentions them so often in his poems. There are the prettiest small birds now in numbers in the lanes, "Coaly hood," the bullfinch; "Yeldrock," the yellow-hammer, and yellowy-green finches. The yellow-hammer, whose odd name comes from the German ammer, meaning a bunting, 


\section{Ladyday to Whitsunday}

has a great many curious local names-Yeldrock, Yorlin, Yite, Yeldring, Yowley and Goldie, which last he shares with the Goldfinch, Thistlefinch or Gowdspink. These names are old, and are to be seen in the antient ballads. They have a common origin in the Anglo-Saxon word geole, "yellow ring "-yellow ring probably from the bird's colouring. It is curious that the poor Yorlin never seems to have had a good reputation in Scotland; he is called a "Devil's bird," and there is a local rhyme which runs thus :

Yellow, yellow yorline

Drinks a drop of Deil's bluid.

Ilka Monday morning, or May morning, according to another version. The devil in the shape of a toad was supposed to hatch the little yorlins, and there was an old saying,

Quarter Puddock, quarter toad, Half a yellow yorlin.

The devil was further said to fly away with any one who shot a yorlin, but even such powerful protection did not always avail to save its nest from being harried, and its rather melancholy little song is sometimes given thus :

Deil, deil tak ye

Me to big a bonny nest an' ye to tak' it frae me ;

though some say he is merely calling for "a little bit of bread and no cheese!" a humble hedge-beggar. The Devonshire version is "Little bread and no cheese," by which name he sometimes goes. The greenfinches used to be called "grene serenes" long ago, and are so termed in Lindesay's "Complaynt of Scotland." "Green lintie" seems the commonest name here. "Grene serene" is probably from the French serin, a small finch. An old Scotch term for a person in charge of a granary was a Graineter, from the old French grenetier, and grain or grane was the Scotch word for a twig, so perhaps "grene serene" meant the graineating finch. Wordsworth has a pretty address to the green linnet, calling him brother to the green leaves. I 


\section{Stray Leaves from a Border Garden}

think he must have meant my pretty green lintie. In Germany he is the millet-bird (Hirsenvogel) and also Grünfink, greenfinch. In Italy he is the Verdone, and in Spain Verdecillo, the "little green one." There are blue and yellow saucy little tits too ; several kinds of tits hereabouts, marsh-tits, great tit and long-tailed tit ; the most common is the blue tit, called Bluecap and Oxeye. There is an old song, called "Lennox's Love to Blantyre," where Bluecap is mentioned as the lover of Jenny Wren.

" Where's the ring I gae thee

Of yellow gowd sae fine?"

"I gae't to my love Oxee, A true sweetheart of mine."

The great titmouse is said to eat bees, but I have never been lucky enough to see him do it. It seems, he taps at the hive-door, and when the poor bees hurry out to see what is the matter he snaps them up. Gardener says swallows and sparrows do the same, and mice also. Here is a delightful old ballad, dating back to 1575 :

\section{I have a pretty Tytmouse Come picking at my to Gossip with you I purpose To drink before I go.}

The Italian name is Cinci allegra; the Spanish, Alionin; and the German, Meise. Wordsworth's description of the titmouse as a harlequin is so pretty, in the "Kitten and the Falling Leaves," I must note it here.

Lithest, gaudiest Harlequin!

Prettiest tumbler ever seen,

Light of heart and light of limb,

What is now become of him?

Where is he, that giddy sprite?

Bluecap, with all his feathers bright,

Who was blest as bird could be ;

Feeding on the apple-tree,

Made such wanton spoil and rout,

Turning blossoms inside out,

Hung with head towards the ground,

Fluttered, perched into a round,

Bound himself, and then unbound. 


\section{Ladyday to Whitsunday}

There are fat handsome Chaffinches too, wonderfully tame. But I don't know the birds well; I wish I did. The Blackbirds seem to have an extraordinary pleasure in nipping off the heads of primroses, especially coloured ones. I was told it was to get at the drop of water in the neck of the flower, and I was advised to try putting a vessel of water handy among the plants. Certainly, whether it is the earthen water-vessels or not, my poor primroses have as yet escaped.

Lines of black thread, which I was also told was a good preventive, failed utterly to save my primroses, or the crocuses on which sparrows-the avian rat, as somebody delightfully calls them-are equally hard. Over seed-beds it is said to be a good thing to tie cross rows of string, with potatoes stuck with feathers, or bits of lookingglass. The birds are afraid to come near. We are trying this.

April 22.-My tulip-bed is very gay now with the plain red tulip, Van Tholl. Tulips are called "fairy cradles," somewhere, I think. "Tulipase" is the old"Scotch name for a Tulip. Parkinson says of them, "Tulipase do carry so stately and delightful a form, and do abide so long in their bravery, that there is no Lady or Gentlewoman of any worth that is not caught with this delight." With this I do most cordially agree.

Violets and forget-me-nots are out in the sheltered kitchen-garden, and the pretty Lyre-flower (Dielytra or Dicentra spectabilis), Bleeding Hearts, and Clocks and Watches, are quaint old names for this. In America I have heard it is called Lady's Eardrop. I have found in a shady corner of the plantation, under an old crooked cherry-tree by the wayside, a regular little self-sown bed of a dear little old-fashioned bright blue flower (Omphalodes verna), sometimes called Winter or French Forget-me-not. It was probably planted long ago by that same sweet soul to whom we owe so many nice flowers here. Still it may be wild. I have seen it growing on the edge of a lawn in, however, less profusion, in a garden some six or eight miles 


\section{Stray Leaves from a Border Garden}

away. It is said to have been a favourite flower with Marie Antoinette, the unhappy Austrian, and I have heard that it grows in great blue patches in the Hungarian woods, so it may be she saw it in the old happy days before she journeyed far away to France, and perhaps when she was in prison, in the murderers' hands, she may have remembered the sunlit woods where the dear little flower looked like a bit of blue sky beneath the trees. There is still, I believe, to be seen somewhere in Austria a little old miniature of this poor Queen, representing her as a bright young girl with a red velvet ribbon round her neck, looking like a bloody line on her fair white throat, painfully prophetic. The French forget-me-not is an old plant in English gardens. Parkinson mentions it for one, and there is a white variety, not, however, so pretty. There is a big New Zealand forget-me-not I should like to see, but I believe this climate does not suit it. Boy brought me two bluebells to-day, in grey tightly folded bud still; wild hyacinth it is here and crowflower. Tannahill writes of the "bluespreckled crawflower." St. Dorothy's Flower it was also sometimes called, because it blooms about St. Dorothy's Day. A little later there will be masses of them. I remember a wooded ridge in Wiltshire where

The sky overhead was blue and bright,

The earth underfoot one blue delight

With bluebells-the fairies had passed that way.

The ground ivy is out now in the "plantin" and also in the Dene. Grund Davy is its name here and Ale-hoof. This was also its name in Queen Anne's days, as also Tunhoof. Chaucer talks of garlands crowning alestakes, and this plant was used to clarify ale. Its name is derived apparently from hufe (A.S. crown), Ale-crown, and Tun-hoof Garden Crown. Its Latin name was Corona terrce. Its name was at one time usurped by the Periwinkle. Why it was sometimes called Devil's Candlestick I cannot find out. The tiny purple dog violets $(V$. de Chien $)$ are to be seen on every bank now; they look so pretty among the creeping 


\section{Ladyday to Whitsunday}

trails of brown-veined ivy, and the sycamore-trees are nearly all green; the beeches, too, are bursting; while the old lilac is a mass of softest emerald leaves and purpling amethystine buds. If you cut a branch just at this stage, and keep it in a warm room in warm water, $I$ am told it will bud and bioom. I must try this. Some people carnot bear its smell, and others call it a vulgar flower because no cottager's garden seems ever without it. But I think it shows Hodge's good taste. The snowberries and dog-roses are tipped with green. In Devon, rosehips are sometimes called Pig's Snouts, and here Dog-hips. In Sussex the fluffy excrescences sometimes found on the briars and wild roses (the nest of a fly, I believe) are called Robin Redbreast's Cushions, and said to be a cure for whooping-cough. It is curious that in English, Dutch, German, Spanish, French, Latin and Greek the wild rose is called always the Dogrose, probably from the widespread belief that the root cured hydrophobia. Thus: English, Dog-rose; Dutch, Hondsroos; Germany, Hundsrose; Spanish, Rosal canina; French, Rosier des Chiens; Latin, Rosa canina; Greek, $\kappa v \nu o$ o odov. There is a pretty old legend that the Crown of Thorns was made of briar rose branches, and wherever on the earth fell blood-drops there lay Roses.

I saw the other day in some paper how an old labourer had died from the prick of a dog-rose thorn; "cankerbush" it is called in some places, and also by Shakespeare. The chestnut leaves are beginning to uncurl their green fingers out of their sticky brown gloves. I think it must be the lively squirrels who strew the avenue with tufts of leaves from the chestnuts and beeches. But why, I wonder; or can it be birds? There is a legend that once upon a time there were no squirrels in all the Borderland, and then some-Duke of Buccleuch imported a pair from Norway to Dalkeith, and thence they spread all over the Merse, which accounts, I think, for their looking different to the common squirrel as I have seen him in Yorkshire and elsewhere, and having very often lighter-coloured tails. I saw one with quite a white tip to his tail the other day, and one 


\section{Stray Leaves from a Border Garden}

almost black. I remember seeing a completely black squirrel once in a cage at Biarritz. I do not know if they are common in that part of France. Boy asked Gardener to catch him a squirrel for a pet, but Gardener said they were not nice as house pets, and I told Boy I was sure Master Squggie would prefer a wild life.

We were asked a few days ago if we had heard the chiffchaff yet. He is supposed to come earlier to these woods than anywhere else in the neighbourhood, and is, I believe, rare in Berwickshire. I must look out for the tiny green gentleman. I have not yet seen any kingfishers on our little river, though I know they have been seen on the Tweed-the King's Fisher, as he used to be called, the "sea-blue bird of Spring." I heard a most extraordinary story the other day, how an angler left his rod hanging over the water, fixed by the handle to a tree-bough, and came back to find a kingfisher on the hook! A majestic grey heron (" herne "they call it on the English side of the Border) was on the haugh by the water yesterday, afterwards winging his way in the direction of the Castle Loch, or Hen Poo' (Pool) as it is commonly called. There he will have the aristocratic society of swans and a variety of ducks. A white heron was seen one day on the Tweed. What a beauty he must have been! I think swans must be very clever birds. A pair from this very loch were once located on a pond in the close proximity of the Tweed, but not within sight of that river. They were fed at intervals, and apparently had plenty of waterweeds, \&c. But remain they would not. Being pinioned, they had no means of locomotion except their feet, and, in spite of constant watching on the part of the gamekeeper and his family, it was a common cry, "The Swans are away to the Tweed!" In order to leave the pond they did not follow the burn down to the river, but took a direct line across a field to the Tweed, which river, though not far distant, was completely hidden from view by a steep ridge.

Fearing they would stray and be lost, they were removed to two larger ponds farther inland, close to each other. 


\section{Ladyday to Whitsunday}

Here they consented to stay awhile, but eventually marched off to the river, finding the shortest road.

Towards nesting-time they seemed to try various retreats on the river. but apparently were not suited, and they went back to the two ponds. Here they made a nest on an island in close view of a well-used footpath. While the hatching was going on the male bird was never off sentry, showing a fierce front to all intruders except the man who came daily with their food. At last three cygnets were hatched, and when they were so far grown as to be up to the journey the whole family set off to the Tweed, and were met marching along, Papa leading the way majestically, then Mamma, followed by the three fluffy grey swanlings. How I should have liked to have seen them! On arrival at the river the party separated, and wandered far and wide, up and down, till Queen Swan was somehow killed and one of the cygnets disappeared. The other two were given away, as the fishermen complained the swans did mischief. King Swan was afterwards provided with a second consort, and again set up housekeeping at the Two Ponds. But when the second family were sufficiently grown they again travelled in a body off to the river. This time, however, the keeper, meeting them, drove them back to the ponds, but carried King Swan to the river. $\mathrm{He}$, however, shortly returned, with the evident intention to get his family. A second time he was taken to the river, and a slight weight tied to his foot, which prevented him walking any distance. $\mathrm{He}$ then contented himself with the river and became quite a pet with the fishermen, being allowed to visit the Queen at the ponds at nesting season. But, alas, one day poor King Swan was found dead on the banks of the Tweed, in all probability slain by some loafer with a gun calling himself a "sportsman." Queen Swan is still keeping house at the ponds alone.

April 28.-We are beginning to find nests now in the bushes. To-day, as I was cutting out some dead wood from a box-tree grown into an enormous bush, there are several such here, I nearly dislodged a nest with three blue eggs 


\section{Stray Leaves from a Border Garden}

speckled with black, probably a thrush's. I do like the quaint old Scotch names of throstle-cock for the thrush and storm-cock. There is something quite astonishing in the number of birds and nests after the terrible scarcity of both in places like France, for instance, where the peasants and, indeed, every one who can handle a gun makes a point of shooting down the poor little cockyolly birds. The woodruff is beginning to carpet the woodland with its soft green tufts and tiny white stars of flowers. I like the old legend that the woodruff was said to have been the Virgin's bed. Hépatique Etoilée is the pretty French name; Sternleberkraut (Star Liverwort) and Waldmeister (King of the Woods) are the German names. Matri sylva was one of its old Latin names, which, I suppose, may be rendered Wood-mother. The Anglo-Saxon name was Wudrofe.

A showy gold-coloured Doronicum is coming out alongside the Woodruff. It is a case of Una and the Lion-the harmless sweet innocence of little Matri sylva beside the bold Pantherbane, so called because it is such a violent poison. I have heard that in the Tyrol the hunters used to poison the wild beasts long ago with the juice of this plant, yet an old name for it was IVoolfsbane Antidote, as it was said to be a cure for people poisoned by Monk's-hood, and to be effectual against the "Poysonous Bitings of Shrew Mice and Toads!" Its Arabian name of Doronicum is said to be derived from the Arabic Durungi, from its use by Arabian physicians, who in the days of King Richard the Lion Heart were supposed to be the cleverest people in the matter of medicine. A nice name for this flower is Goldenstars. Mort-aux-Panthires is the French name. Gesner, the botanist, is said to have met his death experimenting with Doronicum as a medicine. I wonder if it were really this plant. Wallflowers of all colours are now in full bloom; there is a deep purple one I much admire. In Palestine, I have been told, the wallflower is called "Christ's Blood Drops." This name has also been given to the red anemone.

The rhubarb plants are high and bushy now. I remember a little garden where an old cobbler had utilised the Rhubarb 


\section{Ladyday to Whitsunday}

in his flower-borders as a beauty plant among Pinks and Roses. And really it did not look amiss.

May 4.-The trees are nearly all out now. What a difference it makes; the contrasts of green are too lovely! The honeysuckle or woodbine suckers are beginning to carpet the ground. I do like the local German names so much -Specklilie and Hahnenfüsslein: "Little hen's-claws." "Ladies' Fingers" is a more elegant Scotch local name.

The Italian, Spanish, and Portuguese are just variations of wood-mother, Madreselva, while the German, Dutch, and French, Geisblatt, Geitenblad and Chêrrefenille, seem to be just synonyms.

The white Bellbind is looking for support; soon the holly hedge in the Rose-garden will be the prey of the graceful parasite. I never have the heart to wage war with it, it is so pretty. Ladies' Nightcaps and Hedge Bells it is sometimes delightfully called. The lily of the valley is showing flower, and we look for Rain to help the increase. One of the old English names for this charming flower was Lily Convally, probably from the Latin Convallis, a valley. It is curious that the Dutch name is Lely Convally, and the Polish Konwallia. Local English names are Ladders to Heaven and Our Lady's Tears.

I have heard it is found blooming thickly in Lapland and Norway, close up to the line of the eternal snows. It is such a pretty fairylike flower, like tiny lamps, but rather difficult to please with its habitat. There are places in England-Lancashire is, I think, one-where it grows very freely, and near Cheltenham, I believe, also, and in St. Leonard's Forest in Sussex, where, the story goes, it sprang from the drops of blood shed by St. Leonard during his three days' fight there with a mighty dragon.

The Snakeshead Fritillary is out now-Checkerlily, as it is sometimes called. There used to be a variety called Queen of Spain's Fritillary. I have not seen this in any modern catalogue. It is rather a nice name. I saw a white variety the other day in Dr. Stuart's garden, very pretty, prettier, I think, than the draughtboard-patterned one. 


\section{Stray Leaves from a Border Garden}

There is an old Scotch word, "dambroded," meaning marked with square figures, and a draughtboard used to be called a Dambrod, from the ancient Swedish Dambrcede. There is a so-called Golden Fritillary. I think I must try and get it. As it is rather more delicate, I will try it in a pot, as I have seen fritillaries make very pretty pot-plants. I should like to see a field full of fritillary; it must be a pretty sight. I believe they grow freely near Oxford, and also in old days near Bury St. Edmunds. It is curious that the name Fritillary comes from fritillus, meaning a chequered board (a game). Jeu de Dames the French called the game of draughts, anciently known as "chequers." The German name for the fritillary is rather nice: Kiebulzerblüme, or the Lapwing Flower.

The Broom (A.S. brom) is golden now in the lanes and on the banks and braes. There is an old song about the broom of the Cowdenknowes, well known in the Merse. The slopes of the Cowdenknowes used to be celebrated for the wonderfully high and thick growth of broom, through which tradition declares a man could ride on horseback and not be seen. Certainly the broom grows pretty high in these parts still, though not in such abundance as it did in old days; here with us it is sometimes nearly nine feet high. The name Cowdenknowes is said to be derived from a Gaelic word Choille Dun, meaning the "wooded hill," and there is an old mansion-house and tower called Cowdenknowes on the river Leader, where Mary Queen of Scots is said to have once spent a night in the course of one of her circuits of justice among the Border towns. Broom bushes were supposed to be favourite steeds with witchwives when they rode forth to their midnight revels, though they did not disdain hemlocks, ragworts, or bay-trees either. Hogg, the Ettrick shepherd, describes the witches' rides very finely. It is curious that a Spanish grandee, the Duc d'Aliaga, takes his title from the broombush. Aliaga means "wild broom" in Spanish, Gênêt is the French, Genistre the Latin, Genistra the Italian, while the German is Pfriemen Kraüt. 


\section{Ladyday to Whitsunday}

The strawberries are in flower now and the currants-how I like their old name of Garnet Berry! - while tiny little gooseberries, looking just fit for fairies, hang on all the bushesthe "berry bushes" as they are called here. The gooseberry used to be called in old days the "feaberry " or "fepeberry," supposed to have come from pfebe, the German name for a melon, perhaps because it is like a tiny melon. The name feaberry lingered in East Anglia. "Grosart" is the old Scotch name, probably from the old Swedish Krusbaer. Parkinson says amusingly of the gooseberry: "It is of much use to bake into tarts or otherwife after many fashions as the cunning of the Cook or the pleafure of his commanders may appoint."

May 5.- The London Pride or None-so-Pretty is out now in profusion, mixed with Blue Speedwell (Birdseyes). Oddly enough, I have heard that in New England it is the pansy that is called None so Pretty. Desespoir de Peintre the French call London Pride ; and no wonder, it is an impossible flower to paint. It is just like a tiny slim candelabra fit for a fairy's table. The syringa is budding, and promises to be lovely ; the poets' narcissus, sometimes called Pheasant's Eye and Sweet Nancy, is out now in masses in the lilygarden. Violas-tufted pansies, I believe, is the more correct name-and pansies proper are out now. Boy and I love Pansies. Tickle my Fancy they used to be called, and they do tickle my fancy exceedingly. I have one looking as if cut out of black silk which is much admired. Stiefmütterchen, or Little Stepmother, the Germans call the pansy, and Unnützesorge. Menues Pensêes (Little Thoughts) is the prettier French name. Spenser talks of the Pawnce, and Prior gives a delightful list of quaint names: "Jump up and kiss me, Pink of my John, Herb Trinity, Three Faces under a Hood," and others. But I think the American names are very delightful too: "Kit Run About, Ladies' Delight, Johnnie Jumpers or Jump-ups, and Heart's Ease." The Italians called pansies Pensieri menuti. Old English names are Heartsease, Herb Constancy, Bird's Eye, and Love in Idlesse. An old Saxon name was Banwort or Bone- 


\section{Stray Leaves from a Border Garden}

wort. In Cumberland I believe the Primula farinosa is still called Bird's-eye, and there used to be a quaint little child's rhyme which asserted that the "lockety gowan and bonny birdeen were the fairest flowers that ever were seen." The "lockety gowan" is the globeflower or trollius, which used to be called "locker goulon" long ago, according to Parkinson, who also calls it the "globe crowfoot." A Border name for it which still, I think, survives in some places, was the "lucken gowan" and Trollflower or "witches' gowan." The Italians call it, I think, Pie corvino or Ranonculo, and a delightful Dutch name in Parkinson's day was Hanenvoet, though I should rather imagine this more appropriate to the Crawtaes smaller species. The pretty Star of Bethlehem, sometimes called Eleven o'clock Ladye (Dame d'onze heures), is now in bloom. Starflower is another nice old name for this, and "feld onion" it was also sometimes called. The Arabian Star of Bethlehem has a very quaint name in Spain : "Oyoz de Christos," or Christ's eye, from its black centre. There is a pretty legend that the Star of Bethlehem was unknown till the Nativity, when on the following morning it was found starring the ground around where the young Child was born. There is a very pretty variety of this flower with backs to the flower petals like green satin. Columbines are beginning now, and lupines. Columbines or Culverworts, according to Parkinson, are "flowers of that respect as that no gardener would willingly be without them that could tell how to have them." They were sometimes called "pigeon grass," and I have thought that the culverkeys in Isaak Walton's pretty description may have been columbines, since I have seen them growing thickly in fields. Lupines I also delight in, and have planted both the white and yellow tree lupines; it is such a graceful shrub! The tall yellow asphodelline is showing its pretty yellow flower-spike. Here I found it went by the name of "fuller's teazle," and had wrongfully enjoyed for a long time the credit of being of use in cloth-making.

A curious old name for it is King's Spear, with which I have rechristened it here. The African marigolds 


\section{Ladyday to Whitsunday}

are also in flower, but I do not care much for ces belles tigrêes.

May 20.-Boy and I found the nest of a little bird, which, I think, must be that of a sandpiper or water laverock. A neat little grey and white quaker of a bird with "a lang neb," as Gardener says - he calls it a waterouzel-which flirts its tail and hops from stone to stone about the low water in the river, crying, "Pwee pwee." It has many curious local names, such as Kittie Needle, Willy Wicket, Weet weet, Kittie Leepsie, Summer Snipe and Water Craw. At first the nest, which was merely a depression in the grass of the river bank, only contained four brown chocolate-splotched eggs, rather like a plover's egg; but the following day we found four downy black and white long-billed bright-eyed tinies, with a dark stripe down their backs like Arab donkeys. And such was their spirit of enterprise, that the very day they came out of the egg in the afternoon we found the nest empty and the four little rovers afield in the neighbouring grass, while "Mammy" was out by the river! Said Boy, "Naughty sandpipers to run out while their mammy was away, and no one to see to their house. They ought to have servants."

"Servants," I said; "what kind of servants ?"

"Bird servants, of course!" The next day they were all away together.

May 2.5.-The Yellow Day-lily (Hemerocallis flava) is out now, and purple and white Iris, old-time Flower de Luce; down by the river, the marsh-marigolds are in clumps. Soucis is the French name, meaning also "cares," and there is a pretty old French carol in which there is a mention of this flower, sometimes also, I believe, called Fleur de Marie. I amused myself once translating this carol, and a pretty girl-cousin set it to music, and used to sing it to her guitar.

\section{CAROL}

Between the ox and grizzled ass

Softly sleeps the little Son ;

A thousand angels in the sky,

A thousand seraphs hover nigh 


\section{Stray Leaves from a Border Garden}

Flying round and round above O'er the mighty God of Love!

Between the Marigold and Rose Softly sleeps the little Son, A thousand angels in the sky, A thousand seraphs hover nigh, Flying round and round above, O'er the mighty God of Love!

In Mary Mother's two soft arms Softly sleeps the Fruit of Life, A thousand angels in the sky, A thousand seraphs hover nigh, Flying round and round above. O'er the mighty God of Love

Upon this holy solemn day, Softly sleeps Emmanuel, A thousand angels in the sky, A thousand seraphs hover nigh, Flying round and round above, O'er the mighty God of Love!

French version (from Noels "Français et Béarnais ")

Entre le bœuf et l'âne gris,

Dort, dort, dort le petit Fils,

Mille anges divins ;

Mille séraphins

Volent à l'entour,

De ce grand Dieu d'amour.

Entre la rose et le souci,

Dort, dort, dort le petit Fils.

Mille anges, \&c.

Entre les deux bras de Marie, Dort, dort, dort le fruit de vie. Mille anges, \&c.

Entre un jour si solennel, Dort, dort, dort l'Emmanuel. Mille anges, \&c.

Entre deux larrons sur la Croix, Dort, dort, dort le Roi des Rois. Mille Juifs mutins,

Cruels assassins, Crachent à l'entour, De ce grand Dieu d'amour. 


\section{Ladyday to Whitsunday}

They are mostly called Kingcups here, not Marsh Marigolds; Wildfires is an older Scotch name, Meadow Bootes is an old English name. A Booite used to be a Lanthorn. Is meadow boote just a field lanthorn? There are lots of blue forget-me-nots now down by the river, and white ones in the garden. I like the Yorkshire name for white forgetme-nots so much-"Think-me-on." A "think-me-on" also means a cheap little present bought at a fair, a fairing. The old story of the German knight who lost his footing gathering blue forget-me-nots for his Mädchen is well known, but I don't think the legend of the origin of the forget-menot as told by the poet Shiraz is as well known, though Mr. Thiselton-Dyer tells it prettily in his charming book of "Plant Folk-Lore." I think it ran somewhat thus, if I remember right. An Angel wandering over the Earth saw a fair daughter of Earth sitting by a stream, decking her hair with forget-me-nots. He lost his heart to her, and fell from his high estate in consequence, being forbidden to enter Paradise till the woman he loved had planted the fatal blue flower all over the earth. So hand-in-hand they planted it everywhere. Then the Gates of Paradise opened to admit them and, without tasting of death and its bitterness, the Daughter of Earth, become immortal, entered the Garden of Paradise with her angelic lover.

May 28. - There is a blackbird's nest in a snowberry bush. First I saw blue eggs in it, and now it has several strong-billed hobgoblins in it, with bits of short black quill appearing on their skinny wings. An old name for unfledged birds in Scotland was "gorblin, gorbet, gorblet," or "gordlin," and the down on them "gorblin hair." In Yorkshire I believe they are still sometimes called "gorbals." In the Lothians a young person used sometimes to go by this name. I took my little chair into the thicket and drew a picture of the gorbals yesterday afternoon. How odd it is young flying birds should be such frights, when young chickens and turkeys and ducks are so pretty! I believe the young of the woodpecker do not even have down on them, but are naked as little worms! But perhaps 


\section{Stray Leaves from a Border Garden}

in their snug nests they don't feel the want of any covering.

The roses are beginning. A crimson dog-rose, which I believe is Rosa turbiniata, has been out some days, and looks quite lovely with its bushy straggling branches spotted with flat crimson flowerets. Rosa spinossima, the Burnet rose, found on sandy seabanks not very far from here, and called locally the Cat Hep, is said to be the only rose which grows wild on Holy Island (Lindisfarne). In all probability it was introduced by St. Aidan and his monks. A similar little rose grows wild in East Anglia, in the neighbourhood of Dunwich, remarkable for the extreme smallness of its leaves. James Bird, the Suffolk poet, writes prettily of the "Dunwich rose with snowlike blossom, soft pure and white as the cygnet's bosom." The tradition is, it was planted by the Grey friars, whose ruined church and monastery still overlooks the sea that has engulfed the town of old Dunwich. The fennel which I noticed growing wild in the same neighbourhood was probably a stray from the Greyfriars' herbarium. Here the dog-roses are called Dogheps. "Hep" is an old English (and Scotch) word for " hip," from the Saxon. The Gloire de Dijon-Glory, as it is called here, which grows on the kitchen-garden wall-is covered with buds blooming fast. I do not think I care much for this rose ; to me it is rather coarse and uninteresting. Sir John Mandeville (that charming old myth !) gives such a pretty legend as the history of the birth of the rose, I must note it here: "At Betheleim is the Felde Floridus, that is to seyne the Feld florisched; for als moche as a fayre mayden was blamed with wrong and sclaundered, for whiche cause sche was demed to the Dethe, and to be brent in that place, to the which she was ladd; and as the Fyre began to brent about hire, she made hire preyeres to oure Lord, that He wolde helpe hire and make it to be knowen to alle men of His mercyfulli grace. And when sche had thus seyd, sche entered in the Fuyr; and anon was the Fuyr quenched and oute; and the Brondes that were brennynge becomen red roseres, and the Brondes that weren not kyndled becomen 


\section{Ladyday to Whitsunday}

white roseres, full of roses. And these weren the first roseres and roses, botte white and rede that evere any man saughe."

The delphiniums are in bud, and it is amusing to find our Scotch gardener calling the white delphinium Elijah's Chariot; why, I do not know. I like the old name, too, of Helmet-flower. How beautiful the laburnum is !-Pea-tree or Peascod-tree, as it used to be called hereabouts.

There is a small croft lying between the brown river and a high bank covered with beech-trees; here the laburnums form a perfect golden fringe. Goldregen (Golden Rain) is the pretty German and Swedish name. The Dutch call it Goude Keten, and an old English name was Gold-chain. I always think it so well suited. And here, in the lush meadow-grass, I found purple orchis, Shakespeare's long purples (unless he meant loose-strife or willow-herb, which perhaps he did), kingcups and the loveliest turquoise-blue forget-me-nots. There are three kinds of orchis here-Mascula, Maculata and Latifolia, and they have very queer local names : "Cockskames," " Dead man's thumb," because the root is said to have that shape, "Addergrass," "Hens," "Henscombs," "Deilsfoot," and "Adam and Eve." Testicule de Prêtre and Sabot de Vénus are the French names, and Mannliches Knabenkraüt the German. Foolstones was an old English name. There is a Border belief that if a village maid desire the love of any particular swain she must hide an orchis root in his pocket and he will lose his heart to her. The Marsh-marigolds, too, have quaint local names-"Kingcups" and "Yellow gowans." There is a saying, to an invalid: "Ye'll get round again gin ye had yer fit on the May gowan."

But I am not sure that in this case "gowan" does not mean a daisy - "daisy little," sometimes called "ewe gowan." The big oxeye daisies the children call here " horse gowans." In Norway they are called Praste, meaning "priests," from their resemblance to the ruff worn by Lutheran pastors. Allan Ramsay, the old barber-poet (what connection is there between barbers and poetry, I wonder ?), sings of "burn banks where the yellow gowan grows," meaning marsh- 


\section{Stray Leaves from a Border Garden.}

marigold (Caltha palustris). His quaint old timbered house with its projecting window was still standing when last I wandered in the "Auld. Toun," but was menaced with destruction, I - believe, by the improver (hard be his bed!), whose hand is as heavy in Auld Reekie as elsewhere. I have heard there is a Scottish society which aims at saving old buildings of interest, and makes protests against the erection of eyesores. Here is, methinks, a grand opportunity for a protest against Vandalism. Wildfire, pronounced "Willfire," is a local name for the marsh-marigold, also called "King-cobs," and Willfire is also used for the marsh-flame, known as Will o' the Wisp and Jack o' Lanthorn. "To go wyll " was an old Scotch term for losing one's way. I saw a lovely double variety of this pretty flower the other day in a garden which I must get. Boy and I were much amused to-day to see a large Rat hunting a terrified young Blackbird along the path. The blackbird seemed quite to have forgotten he could have escaped by taking wing !

There is a pheasant sitting by the path to the kitchengarden within a foot of where people pass daily. She looks so quaint with her speckled body in among the doronicums' golden stars and the thick primrose leaves under the lime-tree bush! I went and drew her to-day. She sat perfectly still. I could see her quite plainly, although some of the lime-tree branches mask her nest. Still, if one stands exactly in front of her, one can see her as if it were framed in a leafy picture. Oddly enough, it was not the gamekeeper who first spied her, but, as he put it, "a town lassie, who was just here for the day like, had the sharp eyes." 'There is a tame hen pheasant who has haunted the gardener's cottage for several seasons now.

Yesterday we found a wren's nest in a tall raspberry cane, with one egg in it.

May 29.-Boy went privately to see if there were more eggs in the wren's nest, and, alas, by accident pulled it down, and the one egg, anointed with salt tears, lies broken beside the pretty little snug habitation. I believe these birds are fairly common hereabouts, but I never saw any nest before. Boy 


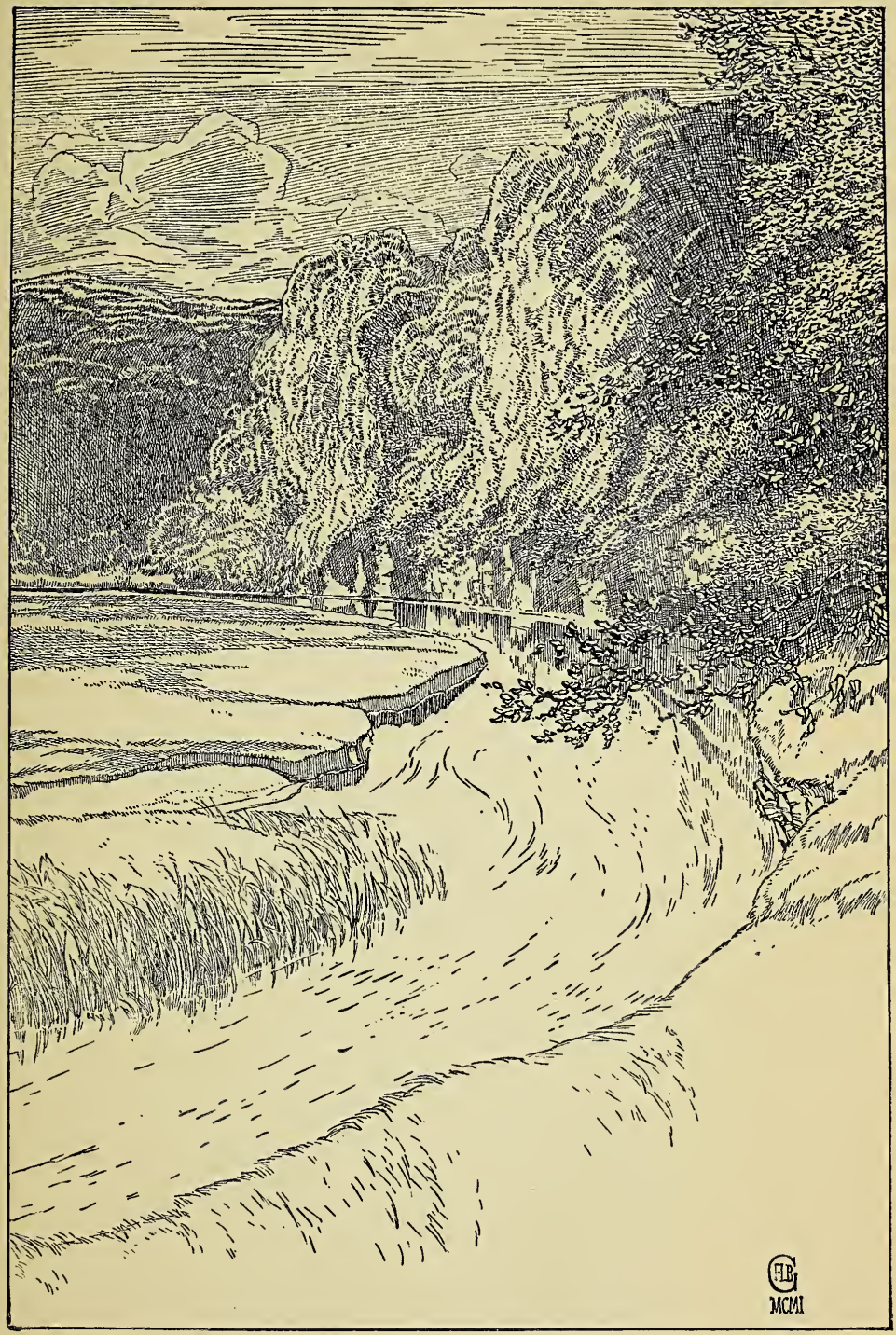

The Waterside Croft. 



\section{Ladyday to Whitsunday}

had to hearken to a sermon on being kind to the birds. Is it inherent in small boys to rifle nests, I wonder?

I have heard that in some parts of Scotland the Wren was long thought to be the wife of the Robin, which may have come from the old nursery rhyme of Cock Robin and Jenny Wren. There is also a quaint Scotch curse on birdsnesting :

Malisons, malisons, mair than ten,

That harry our Ladye of Heaven's hen.

I do like Kingsley's song about the wrens so much"Juventus Mundi "-about the poor little Arab children who were carried off by the slave-traders and ill-treated till they died and were changed into wrens.

This place seems a very Paradise of Birds. "God's Poets hid in foliage green," the air resounds with rival songs all day. Our birds are so fearless and bold, they build anywhere close to the paths. A nest of young Sparrows is in a low fir, quite close to the Church Walk, and they do not seem in the least perturbed when we stop as we go by and look at them all squeezed up close together in the nest. In the thickly matted rhododendrons there is a nest of Green. finches, and if one stops to look at them, they all open their mouths simultaneously. I think some day I shall put in some bread. "Green linties" is a name for them I rather like. There is a suspicion a pair of Brown Owls have a nest, either in the big variegated holly or in a beech close by the house, since their hooting sounds quite near at night.

The evenings are so light now, at 7 P.M. one scarcely needs a lamp. David went out fishing after dinner and actually caught some trout.

May 30.- The first bits of syringa flower were found to-day in a sheltered nook; very shortly the bushes will be white. White Pipe-tree is a nice old name for this pretty tree. . . . But I never saw the syringa in full flower. Circumstances uprooted me the old Cabbage; and my Roses and Lilies bloomed for others that year. 


\section{CHAPTER III}

\section{HALLOWE'EN TO CANDLEMAS}

October 31.-All Hallows Eve. I don't think Hallowe'en seems to be much kept hereabouts in these modern days of progress ; one does not hear of people gathering together to crack nuts on Nutcrack Eve and make merry like the Vicar of Wakefield. Romance seems to be dying on the Border, choked by civilization and Board Schools. All Hallow Fair, however, still survives; an old custom, but not very romantic, as it is nothing but a large cattle-fair held near Edinburgh. Bonfires used to be lit in villages, called "Hallowe'en bleezes," and the young folks used to dance and sport round them. There was an old belief that Witches and warlocks held a sort of assembly at this time, called a Hallowmass Rade, as they were said to ride thither on the traditional broomstick transformed into a steed. There is a quaint old saying, "Eat an apple before the looking-glass on Hallowe'en and you will see the face of your True Love." Burns alludes to this in one of his poems.

November 2.-Jour des Morts (All Souls Day). Beans were blessed to-day in England in old times. I remember on the Jour des Morts that, as a child, I used to watch our old Provençale cook Génévieve laying out roasted chestnuts before the fire and explaining, as she did so, that they were for "Les Morts," who would eat them in the night. Certainly they were always gone in the morning, when I went to investigate. This is also, I believe, a Piedmontese custom. 


\section{Hallowe'en to Candlemas}

In India there is a weird Mohammedan festival called Shub'rat, or the Night of Record, a sort of All Souls Day, when little earthen plates of food are set out at nightfall and dedicated to lost loved ones, and candles lit around to do honour. The ghosts are supposed to come in the night and partake of what has been set for them and it must be a wretchedly poor household indeed where something is not prepared. October the Saxons called Wyn monath, or the Wine Month, and Winterfulleth the Fall. It is curious our American cousins still talk of the fall where we would say autumn. October, the eighth month of the Romans, is, I think, the month when one sows in hope. We have been very busy putting in bulbs and trying vainly to clear away the endless leaves.

Gradually the last of the flowers have slipped away from us; several successive frosts have mown down China-astersQueen Margrets, as the Americans so prettily call them, and Reine Marguérites the French; godetias, those lovely flowers like satin; chrysanthemums, delightfully called by an old Chinese writer the "flower of culture and retirement"; cornflowers (Cyanus), " ragged sailors," a quaint American name I like; and rockets, the Queen's Gilloflowres, and even the much-enduring Russian wallflower, Erysimum Peroffskiamum, or Treacle Mustard, a great favourite of mine. Even the holdfast Michaelmas daisy, called "Good-bye Summer" in Scotland, and the fiery marigold have now succumbed, and only a few late China rosebuds still linger. I do not wonder that a Silver Marigold was one of the prizes at the Floral Games of Toulouse, it is such a beautiful flower to my thinking! I love to see a blue bowl full of these warm glowing flowers on a dull grey day. In a certain little old china shop, where I like to poke around, there are delightful bright yellow milk basons lined with blue, and blue china tumblers for milk, and blue mugs. I found a bunch of marigolds in one of these mugs on a kitchentable one day, and it did look so pretty and cheerful! I even found a Blue Rabbit which delighted Boy. Other prizes at Toulouse were a' Silver Violet, Wild Rose, and 


\section{Stray Leaves from a Border Garden}

Golden Amaranth. There is a Mexican legend that marigolds sprang from the blood of the old Mexicans who fell victims to the lust for gold of the Spanish Conquistadores. The snowberries and the hips and haws are abundant just now, and the hollies positively gorgeous, but I should admire them all much more did I not feel they are the heralds of Winter, that dreary season when one has to live on Patience and Hope. The rockets are well named by our American cousins "Farewell Summers." Hollies seem to do particularly well in Scotland. I know of at least two places where the holly hedges are said to be fifty feet high. In Pliny's days holly was planted near houses to keep off lightning, it is also said to keep off witches, while a decoction of bark and leaves was good for bruises. Holly crowns were presented at weddings by the old Romans in token of congratulation, and possibly with the view of averting illluck from the married pair. Butcher's-broom, which is used as a substitute for holly at Christmas in the English churches on the Riviera, grows in some gardens hereabouts ; an old name for it is Kneeholly; I suppose because it seldom grows higher than one's knee.

How pretty chrysanthemums are-the "golden flowers"! There is a quaint legend current in the Black Forest how a poor woodcutter coming home one evening in the snow found a poor little child. He took it home and cherished it, and his family gave it a share of the scanty Christmas Eve supper. Before lying down to rest the little wanderer prayed aloud for the people who were so kind to him. In the morning, lo and behold, it was the little Christ-child who was among them! The woodcutter and his family fell on their knees, and when at last they looked up the Christ-child had disappeared. The next day the woodcutter, passing the place where he had found the little lost child, saw in the snow a cluster of golden flowers which he took home. I read the other day an interesting description by Alfred Parsons, the flower-painter, of some curious chrysanthemums he saw in Japan. At Tokio, in a street of chrysanthemum gardens, enclosed each with a high bamboo 


\section{Hallowe'en to Candlemas}

fence, there were groups of "life-size figures, mainly covered with chrysanthemum flowers and leaves. They represented scenes from history, the drama, or Buddhist mythology, and were constructed with a framework of bamboo, inside which the flower-pots were concealed, the shoots being brought through the openings and trained over the outer surface. The heads and hands were made of painted wood, and swords and other accessories added to make them more lifelike; the draperies, of living leaves and flowers, were skilfully arranged in large folds, and, as in most of the popular shows, they depicted the costumes of Daimio and Samurai of the past." I told Gardener about these wonderful flower-statues, and he was much interested, but said he thought it would be difficult to compass here. Certainly, without a model, it would be impossible.

The trees have been gorgeous with red and yellow leaves, there is a yellow glow over all the "plantin." But the branches are fast getting bare, and the squirrel "Adjidaumo" is no longer hid as he scuttles gaily along the boughs of the big beech by the drawing-room window or peeps at me round the bole of birch or fir. I watched two squirrels today for half an hour playing a sort of hide-and-seek in the old beech; it was wonderful what slim boughs seemed able to support their weight, and how they jumped and skipped about, springing such distances! Curious to say, a squirrel was seen sitting one day side by side with a portly brown owl on a branch of this same old ivied tree! The Red Indian name for a squirrel is so nice, "The little one who sits under his tail." We have only had one very slight shower of snow here, though elsewhere in the neighbourhood they have not been so fortunate, and indeed the air has been comparatively so soft and damp that actually a pink anemone or two, and some auriculas, have peeped out, and some ill-advised crocuses are showing their tiny white teeth above the ground. The lovely ferns are all sadly draggled by the wet and frost, only the moss is fresh and green and beauteous under the fallen leaves. 


\section{Stray Leaves from a Border Garden}

Here is a little what I may call "Poème de Circonstance":

Yonder the turret where my Lady sleeps, Under her Casement see a Gardener sweeps

The fallen yellow leaves as fast they fall ;

The year is ended-they do but recall

Past golden hours when the small birde's song,

In the now leafless branches echoed long,

The memories of fled Summer strew the way

The little gardener sweeps them all away.

Beneath his blouse of blue methinks peep wings,

A little Love, whom Time, the old man, brings

Sometimes to help to make the garden fair,

For Time has much to think of, many a care.

He trims the eglantine with dimpled hand,

Binds wayward sprays with softest withy band :

The pruning-knife of Love who doth not know,

Some trace of it must every garden show.

The heart-shaped beds set deep in lush green grass

He rakes with care.-My Lady loves to pass

By there, when sunbeams flicker in the trees

And softly whispering comes the summer breeze.

His work all done, he spreads his little wings,

Taps at my Lady's casement, sweetly sings :

"Joys and sorrows

Bright to-morrows,

All the pages of the Year

With proud bearing

Velvet wearing

See in glittering train draw near!

A gay young knight

In armour bright,

With a shield without a stain-

Wake to greet him,

Rouse to meet him,

Coming o'er the whitening plain!"

How pretty the Christmas-roses are when well grownthe Christmas-flowers, as they are sometimes called! I think they are some of the loveliest flowers we have, whether it is the white variety with its pale green shadows or the dark pink. I have heard that at Christmas-time Covent Garden Market is just a show of them. I should like to see it.

There is a legend-German, I think-about the black hellebore, that it bloomed first of all in Eden, where it 


\section{Hallowe'en to Candlemas}

was called the "Rose of Love." But, after Adam and Eve were cast out of the Garden, their grief was such at leaving all the flowers, that the angels were allowed to give them the "Rose of Love" to take with them into the flowerless waste white with snow. This is the Alsatian Legend of the Hellebore :

A little shepherdess, 'tis said, When the shepherds came to pray

By the Infant Saviour's bed,

Came along with them that day.

When the Magi Kings drew nigh, With their gifts from Eastern land,

Little shepherdess did sigh, That no gift she had in hand.

Soft unnoticed rain her tears Down her little wistful face ;

No one sees her, no one hears, Sobbing in that crowded place.

From the far-off purpling sky To her Angel Gabriel came.

"Little maid, why dost thou cry ?" And he called her by her name.

"To the Infant Jesu there Nothing can I bring; I'm poor ;

But for Him yet do I care, I can only love the more.

Flowers at His feet I'd lay, Roses would I bring, but now Spring is very far away, And the ground is white with snow."

Softly on the saddened child, With her sorrow-clouded eyes,

Then the Angel Gabriel smiled,

"I am come to help thee. Rise."

Forth into the gathering night, See, he leads her by the hand;

Round him glows a halo bright, Lighting up the snowy land.

Speaks a word to frost-bound earth. Wakes the flowers where they rest, Straightway then there spring to birth Roseate flowers on her breast. 


\section{Stray Leaves from a Border Garden}

Overjoyed the small maid now

Hastens to the Saviour's side,

While the Angel o'er the snow

Wings his way where Angels bide.

It is also called St. Agnes'-flower in Germany.

December 31.- - New Year's Eve. We gathered the first bunch of snowdrops to-day, about a dozen, the earliest bunch known. Truly the little "friend in adversity," for this is what the snowdrop means in flower-language.

January 1.- The custom of "First Footing" seems to be dying out here. Old people tell me it used to be an invariable custom for folk to go round paying visits, or, as they put it, "calling for" their friends and neighbours on New Year's Day, being made welcome with cake and wine, ginger cordials and homebrews of various kinds. Children were wont to begin quite early in the morning, running round from room to room, paying visits to the different inmates, with shortbread as a gift in hand. This same custom of paying visits of ceremony on the first day of the year prevailed in Germany, and is still the custom in France, where I remember a species of Christmas-cake and "Vin cuit," a sort of thick, sweet home-made wine, being offered by poor people. New Year's Day altogether always was of more account in Scotland than Christmas Day, though of late years the Episcopal Church reverence for Christmas Day seems to be gaining ground with the Presbyterians, and Christmas Day taking the place of New Year's Day in the way of holiday and present-giving and prevalence of Christmas-trees. Watch Night services are not infrequent now in Edinburgh at Yuletide, though I believe they have prevailed in other parts of the world for some time; at least I know they are much frequented in the West Indies. Hogmanay, as the last day of the year used to be called here, was a time for present-giving, and a special cake was baked in honour of the night called a Hogmanay.

December was called the Winter Month by the heathen Saxons, but the Christian Saxons called it the Holy Month, 


\section{Hallowe'en to Candlemas}

or Heligh monath. It was also called Guil erra. Guil was the term for the feast of Thor, the thunder-god, and the word "yule" is said to have come from this word. It meant the gathering in of all, the harvest of the year.

January 6. - Twelfth Night. We crowned no King of the Bean, but Boy had a little Christmas-tree, and we gathered, to enjoy it with him, a number of little neighbours. It is wonderful how far some of these sturdy little Borderers will plod for a "ploy," a "cake-walk," as a gathering of the sort is delightfully called in Jamaica. We introduced to their wondering Presbyterian gaze the Christmas tableau called in France a Crêche, and in Spain a Nacimiento, such as delights yearly Italian, French, and Spanish children. I felt a little as I imagine Mary Queen of Scots must have felt when she introduced her Scottish Court to the gay French pastime of the Feast of the Bean, and the grim Scots lords looked on wide-eyed and solemn at the sport around the fair Maid of Honour who drew the Bean in the Twelfth Cake, and appeared resplendent in a dress of cloth of silver and so many jewels (lent by Queen Mary) that "more in our whole jewelhouse," writes enviously the British ambassador, "were not to be found." I used to love making a Crêche in my childhood, and now my wee Scots laddie has taken kindly to the pretty old Provençal custom. He toiled like a little beaver for days before, bringing along in his little cart moss-covered stones, branches of laurel and box, and ivy and holly, the "Women's Christmas herb," as old Bullein calls it, which, cunningly blended, and powdered with flour and cottonwool, do duty for the lentiscus, myrtle, and rosemary branches which, similarly bepowdered, make the winter's landscape around the thatched shed and Virgin and Child. Then out of the box, wherein they repose all the summer months, come the dear little earthen figures, veritable gens de la Crêche, come all the way from the far-off shores of the Mediter ranean. The Kings with their gaily painted blue and red robes and gilt crowns-how fascinating was Baltasar, the 


\section{Stray Leaves from a Border Garden}

black king, and his armed attendants with camels! How tiresome the Camels were! I shall never forget, losing their heads, which we had the utmost difficulty in sticking on again with sealing-wax, and a host of little dear shepherds with big shady hats, and villagers each bearing an offering for the Child. There was the old woman and her basket of eggs, the man with the giant pumpkin or melon, the little boy with the black cock under his arm, and others. These all were set in procession among the rocks and trees, and sheep were cunningly disposed on the miniature heights and in the valleys, and by the side of the lookingglass lake. Then the silver Star was fixed above the shed, and how proud we were of the two tiny waxen angels, with outspread wings, who hovered (at the end of the two black threads) above the thatch! By the door was St. Joseph"in a dark purple robe, and St. Anne within, a kneeling figure with a white cap, and Mother Mary in her invariable skyblue dress. How we cherished the little Bambino! he was so small he was easily lost, and then where would our Crêche have been? In Germany they make what are called "Christgartens," and whole little villages are set forth, and churches, and even churchyards, the white tombstones being represented in one case I know of by Almonds !

By rights the music of pipes and carol-singing should be the accompaniment to a Crêche, but, in default of these accessories, Boy insisted upon setting an ancient music-box a-going, which reeled forth " La Grande Duchesse," "Romeo and Juliet," and "Vie Parisienne," winding up with "Scots wha hae wi' Wallace bled" as the most appropriate finale, somewhat to the amusement of the elders present, but entirely to the juvenile contentment. The following carol from the Spanish is such as is often sung at a Nacimiento, and is a favourite one with Boy:

See, the Redeemer of all Souls

Is born to-night in a stable shed;

He lies between the ox and ass, With hanging cobwebs overhead. 


\section{Hallowe'en to Candlemas}

Thus Melchior.

Come, play the pipes and blow the horn,

Be joyful, 'world, that God is born ;

This night the wondrous Child was born

Who should, my little one, have been

Not laid amid the hay and straw,

But clad in gold and velvet sheen.

At Bethlehem, before that door,

Sun, Moon, and Stars bowed down,

St. Joseph and the Virgin Mother

Knelt to the King without a crown.

Such light shone from the stable-door

That "Fire" was around the cry ;

But hidden in the humble thatch,

It was the Star from the far blue sky

I am a poor little Gipsey

From Egypt come I here,

And to the Child of God I bring

A little cock and hen.

I am a poor Gallegan

From Galicy I come here,

And to the Child of God I bring

A little linen sark.

To the newborn Child

Gifts all are offering,

I am of no account so I

Have only a heart to bring.

The Day of the Kings, or Epiphany, in Spain. This is the story of Luisito and Serafina written for Boy:

Luisito and Serafina were orphans; their father, a shepherd, had been drowned one night, crossing a mountain stream in search of a lost lamb. Their mother had died of grief. Now they lived with old Aunt Ana, in the last house of the village, where the yellow plaster was peeling off, under the old chestnut-tree. They were very poor. Serafina used to carry water for Aunt Ana from the well, tripping along on her bare feet with the great green earthen pitcher on her head. Luisito helped old Uncle José, the village goatherd, to keep the brown goats on the mountain side. At the first sound of his pipe the small boy would run off and go with him through the village, and drive the goats, as one by one they joined the procession. Then, in the evening, as soon as Serafina heard the distant sound of the pipe she knew the goats were returning home. As 


\section{Stray Leaves from a Border Garden}

they entered the village, each one would go to its own home, and Uncle José would arrive at the end of the village with one goat only-that of the neighbour, Tia Manuela. Then Luisito and Serafina would sit under the chestnuttree and eat their little mess together. Christmas-time was now at hand, and it was cold weather. Serafina used to pick sticks in the wood, and in the evening they used to sit round the old brasero, with its glowing charcoal heart, and try to feel warm. Christmas did not bring much joy to Luisito and Serafina. Tia Ana was a lonely friendless old woman, who could do but little for them. But she did make them a cake with flour and raisins given to her by the wife of Don Benigno, the richest farmer in the village, who had much money to spend. She also took the children to see the new-born Child lying in state in the village church. Oh! the beautiful waxen Christ-child lying on the straw, with the Holy Virgin in her blue robe bending over Him, and San José looking on, and the little ox and mule just like the real ones! Luisito was delighted. "But," said he to Serafina, "why are there no pigs?" And the church smelled of incense and of the rosemary bushes stuck round about the altar. All the villagers were there in their best clothes, and they sang carols,

Oh the glorious, the great high day,

Three kings came by the king's highway,

One with incense, one with gold, One was black, as I've been told,

and litanies to Our Lady the Blessed Virgin, till the oil burnt low in the lamps and it was time to go home. Now after Christmas Day, as they were sitting one evening before going to bed, Serafina said: " Do you know, Luisito, Uncle Curro's Tita told me that on this Day of the Kings the sister of the Curé is going to dress up some of the children as angels, and they will stand in the church to receive the Kings. Oh! it will be fine; and Tita says they do not know as yet who will be the children chosen. Oh! if it could be you, Luisito!" "Nonsense, silly child!" cried 62 


\section{Hallowe'en to Candlemas}

Tia Ana, "they do not want poor children like you. It will be the boys of Don Benigno they will take. What would the lady do with a little dirty one like thee?" The next day Serafina met Tita again, and Tita said: "The Curé is going to give the children who do the angels each a cake and half a peseta (about sixpence)."

"Who are they?" asked Serafina.

But Tita did not know.

"Oh! if we had only a half-peseta, what could we not buy ?" thought Serafina; and then she had a good thought. "I will go," she said to herself, " to the Curé's sister and ask her to take Luisito." So she went and hung about the door of the priest's house, and Aunt Rosario, the Curé's old housekeeper, saw her and ordered her off. But the Curé's sister, the widow with the town clothes, who had come to stay with Father Anselmo, came out and said in her sweet soft voice: "Child, what is it?" and Serafina took courage and said all in one breath: "Please, take my little Luisito to be a little angel!" At first the widow did not understand, but when she did, she smiled, and Serafina thought she looked very beautiful, like the picture of Our Lady over the altar of the village church. "Bring me Luisito," she said, "and we will see about it." "He is with the goats now, but he will be back in the evening." "Come, then, my child," replied the lady, "I shall be looking out for you." Serafina went home in high glee, but she did not say a word to Aunt Ana, who chanced to be very cantankerous that day, "because she is so old, I suppose," thought Serafina. When Luisito came in that evening his little sister told him all, and hand-in-hand they went to the house of the priest. Tia Rosario this time did not drive them away, she told them to come to the fire, and gave them each a pancake. And the Curé and his sister came into the kitchen, and when she saw Luisito, that he was a pretty boy, with red-brown cheeks like apples, and eyes black as the sloes in the hedge, she said, "My Anselmo, do you not think he would make a fine little angel?" 


\section{Stray Leaves from a Border Garden}

The Curé was a meek man, who always agreed with every one, so he raised no objections. Luisito was to be a church angel. And the widow measured how tall he was, and said: "Come to-morrow evening, that I may try on the clothes that I shall make for you." Imagine the joy of the two children as they went home to tell the whole story to Tia Ana! The clothes were very fine. Luisito longed for the Day of the Kings to come, when he could wear them. But the other children jeered, saying, "Truly the widow has found a fine angel, all in rags!" But the child who was to be the other angel did not jeer, he was the son of Don Benigno, and belonged to a good house, where no one laughed at the poor.

The Day of the Kings came at last, clear and cold, with bright sunshine. All the children ran up and down the village singing carols:

He is come, the little Christ-child,

From the heavens far away ;

So they come, the Eastern Kings,

Come and meet them by the way.

Luisito was at the house of the priest almost too soon, but he was afraid of being late. Serafina helped to dress him; the Curé's sister let her come in. When all was done she thought he looked beautiful. He wore a short white tunic, trimmed with silver braid, and a silver girdle, on his head a crown of artificial roses, and fastened to his shoulders pretty white wings. Miguel, the little son of Don Benigno, was dressed the same. Then they went to the church. At the foot of the altar lay the Child upon new clean straw. The two beautiful images of the Virgin and San José were placed on either side. Then Father Anselmo told the little boys to take their places at each corner, kneeling on their knees with crossed hands. The church filled gradually with people; Serafina stood with Tia Ana and looked on. Then came some men of the neighbourhood. José Ibarra, Pedro Ximenes, and Alfonso Allegro, these represented the shepherds, who brought 


\section{Hallowe'en to Candlemas}

small offerings, which they laid before the altar, bowing as they did so. They were followed by three elders of the village, dressed as the Magi Kings, and mounted on handsome horses and attended by their train. They were greeted with loud acclamations, and a shining star was borne before them. As soon as they arrived at the church they dismounted. The first who entered was an old white-haired man with a long beard. This was Baltasar. He knelt before the new-born Child, and making his offering, said: "I bring thee Frankincense as God." The second, representing Gaspar, said, as he put down his offering: "I bring thee Myrrh as Priest." Lastly, the black king Melchior offered gold, saying: "I bring thee Gold as King." Then, while they knelt before the altar, a litany was sung in which everybody joined. Afterwards Father Anselmo gave a short address, and the function came to an end. Then the procession of the kings departed as it had come, whilst all the people gathered at the church door and discussed the show. Luisito went back with the widow to the priest's house, that she might take off his angelic garments, and was given the half-peseta, and in addition a Twelfth Night cake.

"There are two beans in it," said the widow, as she gave it to him. " Share it with thy little sister, child." Luisito promised and departed overjoyed. When he and Aunt Ana and Serafina ate the cake, they found in it the beans, and they were made of china, and had little faces on them. Ah, how pleased Serafina was! "I will keep them for ever," she said, "in memory that you were an Angelito, Luisito mio." But the half-peseta was kept by Tia Ana.

Boy is very anxious to give the birds a Christmas-tree. I have a pretty little Christmas-card of a barefooted Love in a little blue shirt decking a tiny fir-tree in the midst of a snowy glade for the birds. I think it is still the old custom in Scandinavia to hang out at Christmas-time in the barn-yard a sheaf of corn at the top of a long pole for the birds, as their share of Christmas good cheer. It 


\section{Stray Leaves from a Border Garden}

used to be put out for Sleipnir, Odin's horse, to feed on, but it is now put for the birds of the air. Luckily it is mild just now, but, should it turn cold, I have promised Boy he shall be little Love and feed the birds :

"Not even the birds should forgotten be At Christmas time," little Love says he, "So I will deck them a Christmas-tree," And the birds come flocking around to see. Over the slippery upstanding rocks And the frozen snow in cold icy blocks, On each berryless bough that sadly mocks Their hungry souls-birds appear in flocks. Love stood on the tips of his small bare toes Hanging strings of red hips and haws in rows, For the little birds love such gifts, he knows And over the white surrounding snows Are prints of the tiny eager feet Of the birds, who all come in hopes to eat. With bursts of song little Love they greet. Says he, "Merry Christmas." They say, "Sweet."

\section{Jamuary 15.-Welcome little stranger!}

Boy and I went to pay our respects to a little stranger just arrived at the Gardener's cottage. I have always delighted in Hans Andersen's "Fairy Tales," and the story of the stork as a baby-bringer is familiar to Boy, being made clear to his mind by a tiny quaint silver cradle surmounted by a stork with a dear little swaddled baby depending from its beak, which I came across long ago in an old Dutch curiosity-shop. He also loves a little white sugar stork bearing a baby on its back, and likes to hear the story of how it was found in a little old "sweetie" shop on the German side of the Rhine, close to an old stone bridge with a boundary gatehouse in the middle of the centre pier.

He likes, too, the legend of the Lily Lake :

Where infant souls beneath their angels' keep

Do slumber sweetly. ... .

That lies where none may know, by Heaven's gate,

Each little soul dreams of the days to come

But some will never know an earthly home,

But sleeping still with sweetest smile will wait. 


\section{Hallowe'en to Candlemas}

Cometh a rustle in the tranquil air,

With level flight across the purple sky,

The birds of God, the storks, are drawing nigh.

They settle by the lake. The angels there

Lay softly on their feathered outspread wings,

Sweet little blinking souls, and bid them speed

To earth, to all the homes where mortals need

A fresh reminder of the heavenly things.

Endless and varied are the legends concerning babies. The Flemings say they are to be found in the parson's garden, while in different places in Germany hollow trees by ponds are likely spots. I have a charming set of little German pictures, one showing the stork standing in a marsh full of lily leaves with a baby nestling among the feathers on his back; and another, the baby being received at the diamond-paned casement by his guardian angel; and the third, installed in a quaint old dark wood cradle with the white-winged angel bending over him. I think it is in Sweden they are located in the heart of a cabbage, and an English version says the parsley-bed. But, appropriate as either cabbage or parsley bed would have been to our special little stranger, on Boy's interested inquiry if the baby had been brought down the chimney by the stork, he was solemnly informed it came down the river! "On one of the big burdock leaves, I suppose," commented Boy, quite satisfied; adding, "Well, he'd have got dirty coming down the chimney!" and then gave his attention to the shortbread which, as he was further informed, baby had brought with him. In Berwickshire a special bread used to be baked for weddings, christenings and funerals, and called Gude-bread. Another term used both for weddingcake and christening-cake was Dream-bread, as young people were supposed to put some under their pillows to dream of their future lovers. In " Marriage," Miss Ferrier alludes delightfully to this old custom. There are still kinsfolk of Miss Ferrier to be met in Edinburgh, but old ladies such as she describes are now rare.

Boy's idea that the little stranger came floating down the river on one of the big butterbur leaves reminds me of the 


\section{Stray Leaves from a Border Garden}

old Hindoo legend that after the death of Brahma the world becomes covered with water, Vishnu, as a baby on a fig-leaf floating on a milky sea, sucking his toe!

January 30.-We have been under snow for some days now, and it is quite curious to see the hardy snowdrops looking like a green-tipped cloud on the snowy bank. I gathered a big basketful to-day, and have all the beau-pots filled with them. It seems strange to me that among sweet-scented flowers so few people ever cite snowdrops, and yet, when one is gathering them, a soft sweet faint fragrance literally fills the air. I have heard of a snowdrop in which the green was replaced by yellow, being found in a Yorkshire park; it was called the Golden Snowdrop, but said not to be as pretty as the common one. In some parts of Switzerland the peasants call snowdrops AmselBlümen, or Blackbird's-flower, because when they appear the blackbird begins to sing. I asked Gardener whether he had ever known the blackbird sing at that time here. But he replied, evidently very much amused, "Gin the snawdrops waited on the blackbird they wud wait a lang while." There was a curious old custom on the Festival of the Purification of the Blessed Virgin Mary, February 2, of removing her image from the altar and strewing the place over with snowdrops. Tradition asserts they bloom now in commemoration of the Virgin taking the Child Jesus to the Temple. A few early primroses are to be seen, "the patient primrose" sitting, as Wordsworth so delightfully says, " like a beggar in the cold." I was given a small posy of pink and yellow "Primets" on New Year's Day by an old woman in the neighbourhood. She had lived many years in the shadow of the castle. I wonder how many times she had been able to pluck such a posy at New Year. Primroses make the most delicious sweet smelling nosegay. We can well apply to them old Parkinson's quaint remark, "There be some flowers make a delicious Tussiemussie or nosegay both for sight and smell"- the Little Ladyes of the Spring, as somebody called primroses long ago. A few days ago I saw some blossoms of Winter 


\section{Hallowe'en to Candlemas}

Aconite, and an early bloom of Wallfower-Beeflower as it is sometimes called-and a few buds among the Hepatica leaves. The poor Wallflower has, however, suffered from the frost, and the rose branches looked pinched and forlorn. It looks so odd to see the footmarks of the pheasants in the snow and the tracks of the hares and rabbits. There is something very desolate about the garden; it looks so empty and deserted, all covered as with a white sheet, the flowers' winding-sheet, and often a pair of little black and white waterhens, like mourning "Sisters," walking delicately, like Agag, to and fro. It seems as though it would be a long long time ere we see any flowers.

How tame the robins are in winter-time! There is a common saying, "The robins are too muckle aboot the doors for gude weather." Holland, who is, I think, the first Scottish poet who mentions the redbreast, and who lived about $\mathbf{1 4 5 0}$, calls him the Henisman, meaning "page" or "henchman." He certainly is a very faithful little retainer. I saw a lovely cock pheasant this morning high up among the snow-covered branches of the old copper-beech; he did look so odd and out of place, and flew away heavily when I looked at him. I am told they often roost high up in trees, but I never saw one do it before. Boy loves the snow. A fat little bundle in warm coat and red comforter, Master Redcap bustles out into the snow in his high snowboots, and snowballs audaciously every one who passes near him. He went with me to the village to-day, across the little high foot-bridge which spans the river on stiltlike legs-"fowl's legs" as the Russians would say. Down below us the swinging water-gate was decorated with long icicles, and they hung from the cliff by the river and from the old mossy roof of the thatched cottage where I had an errand. They looked very pretty, and Boy wanted to break them off and carry them home. There was a little fringe of ice along the river bank, and we have been hearing fine tales of our little river, how in really hard winters it freezes over, and then cracking breaks up and rushes by with young icefloes tossing on its brown bosom, overrunning the haugh, 


\section{Stray Leaves from a Border Garden}

carrying away the water-gate, and, indeed, threatening the stability of the bridge sometimes. A big tree-trunk was once brought down by the flood and wedged beneath the bridge, which was promptly attacked by a posse of villagers with axes, and literally carved out of its entrenched position, or it would certainly have done for our poor little chicken-legged brigg. Once, when there chanced to be enough depth of snow, a toboggan-slide was arranged in the stubble-field beyond the "plantin." Boy was all eager curiosity to go on the sled, but, alas, there was too little snow, and the inequalities and up-sticking straws were found very unpleasant when the final upset came at the bottom of the slope. Boy gathered himself up and with solemn dignity, slightly impaired by a very much bescratched nose, declined any more rides. "No more tobog, thank you!" I do not like cold weather. I should like to hybernate during winter, and only come out like a tortoise when the sun shines. I wander up and down the wintry paths, so hard and frost-bound, and watch the lazy sur, a red ball, disappear early to rest behind the black Scotch firs. Then we shut out the cold grey evening, pile on the logs, and poke the fire to make "cat's light," and try to believe we like winter. What a curious variety there is in logs ! - the snapping, brightly burning yews and arbor vitæ, tough cherry and crisp ivy-tree boughs, like fossil boa constrictors, beech and elm, and other local wood I do not always recognise at once. Whittier's description of a wood fire and winter fireside is unequalled, I think. I love a wood fire, there is such infinite variety about it! We burn our own wood, and it sounds very cheery, I think, on a dull day to hear saw and axe at work. The wind rises as the evening closes in and wails around shrilly. "Hark," says some one, "the Lammermuir pipes!" And, indeed, the weird music of the wind does at times resemble the sounds drawn from that magic instrument of music, the bagpipe, so beloved wherever the Scottish tongue is spoken. "Balloon music" it was once aptly described by a fair Hungarian. By the way, how curious it is that both 


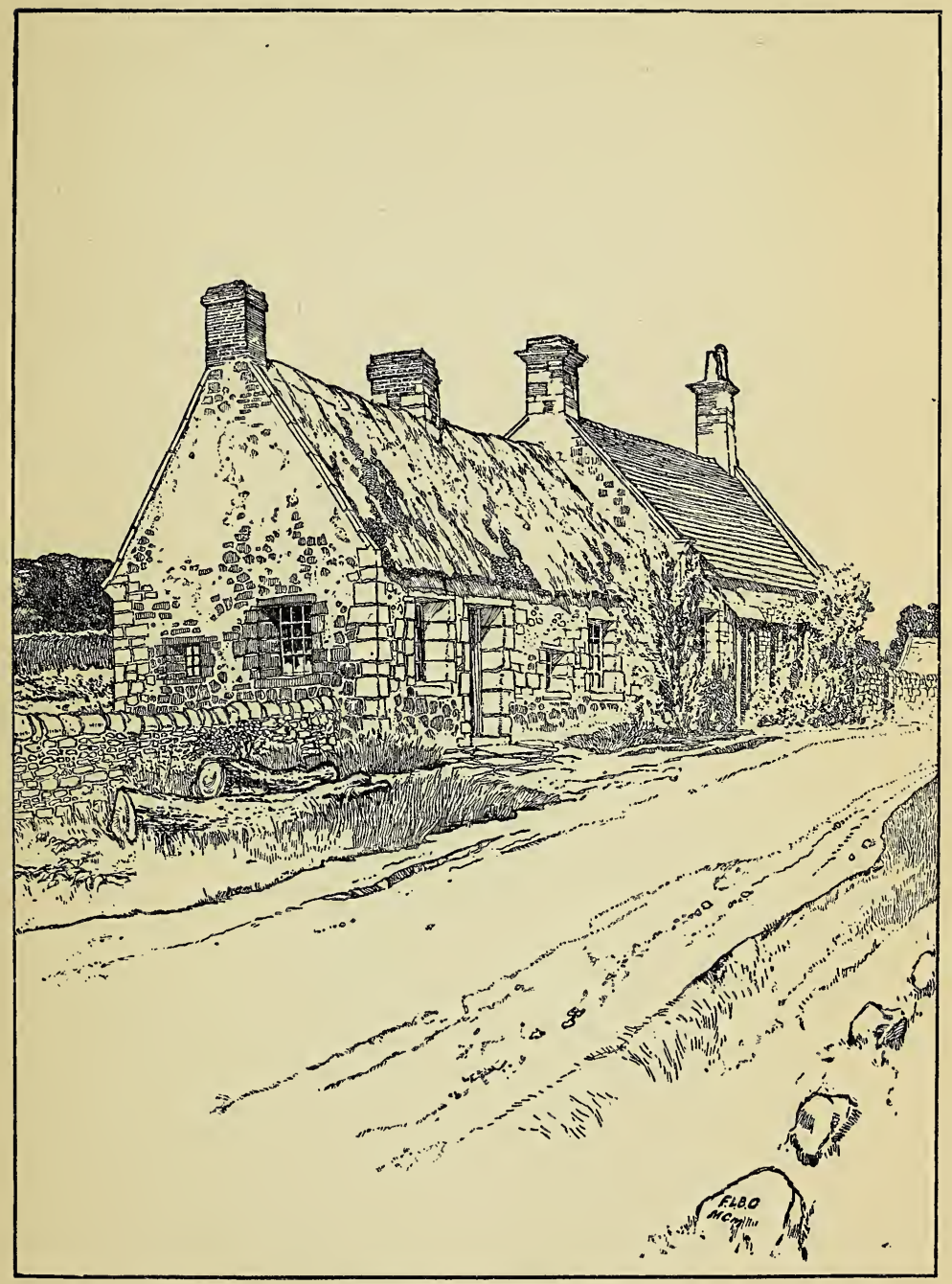

Cottages at Fogo. 



\section{Hallowe'en to Candlemas}

French and Italian mountaineers rejoice in the bagpipe under a different name! What a pity it is Carol-singing has died out. We do, indeed, have a visit once or twice in the winter, about New Year time, from folk calling themselves Guisarts or Gysarts. I wonder if this term was introduced in the days of Mary of Guise, the mother of Mary Queen of Scots, since I believe it was she who first made it the fashion for folk to disguise themselves and play pranks at Yuletide. There was an old Scotch word for "fashion"- "gyse," which, I suppose, is the same as the English word "guise." Our Guizards or mummers are generally farm lads, " hinds" with blackened or whitened faces in such guise their own mothers would scarcely know them, dressed in shirts inside out or flounced petticoats, and perhaps sunbonnets, playing melodies on teatrays and bones, and dancing, and singing comic songs, a sad come-down from-

God rest ye, merry gentlemen,

Let nothing you dismay,

Remember Christ our Saviour

Was born on Christmas Day ;

or,

Now is come our joyfulst day,

Let every soul be jolly,

With ivie let all things be drest.

And every post with holly.

Without the door let sorrow lie,

And if perchance he hap to die,

Let's bury him in a Christmas-pye, And let us all be jolly.

The term Carol seems to embrace much. I wonder if it comes from the old French carillonner, to ring out a peal of bells, or has anything to do with the old Scotch word to "skirl" or cry aloud. To "carol" meant formerly to sing a tune whilst others danced, and even the semjreligious carols were set to very secular tunes. I have heard that Thomas, Archbishop of York, in the days of William the Conqueror, never heard a popular song without instantly writing a religious song to the same tune. "To be sure," as somebody said in later years-Luther, if 


\section{Stray Leaves from a Border Garden}

I remember right-" why should the Devil have a monopoly of all the good tunes?"

In Perthshire I believe it used to be a custom for young people to go round on New Year's Eve singing carols, when they were given small sweet cakes. It was called in consequence "Caroleven."

In Ceylon an old custom is still kept up. The band of the Ceylon Volunteers go on New Year's Eve about the streets of Colombo playing and singing carols. And it is curious that among the native members of the band are sometimes Mohammedans as well as native Christians. The custom of carol-singing is now creeping into many Scotch churches.

Here is a curious old carol, which I came across in a MS. leaflet years ago. I do not know who wrote it, or indeed anything about it, and have never met with it in any collection. But it is pretty, I think, and I should like to know who wrote it:

\footnotetext{
Wake any, watch any, Here in this dwelling ?

Weep any, wait any, Lonely hours telling?

Moan any, pray any, Under heavy load?

Hope any, trust any, Looking up to God?
}

Flies the snow, falls the snow, white upon the wold :

Shines the glow, warms the glow thro' the midnight cold, Light within, dark without, rich and poor together, Bright within, cold without, here in Christmas weather,

Wake any, watch any?

Watch the angels too.

Weep any, pray any?

Angels pray for you.

Moan any, wait any,

Wearied out of life?

Fall any, faint any,

Beaten in the strife?

By the star, by the star, are our footsteps led,

Some from near, some from far, where our Saviour bled.

'Neath the Cross, 'neath the Cross, shelter seek we all.

One for us, one for you, Christ for one and all.

Wake any, watch any?

Ever wakes our Lord. 


\section{Hallowe'en to Candlemas}

Weep any, fear any?

Take His faithful word!

Moan any, strive any?

Breaking Satan's bands?

Watch and pray, hope and trust,

Ye are in God's hands.

There is a delightful book, called a "Garland of Christmas Carols," by Joshua Sylvester, published over fifty years ago, wherein, among other quaint carols, is the following, called "Nay, Ivy, Nay," dating from the time of Henry VI. :

Nay, Ivy, nay, it shall not be, I wis,

Let Holly have the mastery as the manner is.

Holly standeth in the hall fair to behold,

Ivy stands without the door; she is full sore a-cold.

Nay, Ivy, nay, \&c.

Holly and his merry men they dance now and they sing,

Ivy and her maidens they weep, and their hands wring,

Nay, \&c.

Ivy hath a lybe, she caught it with the cold,

So may they all have, that do with Ivy hold.

Nay, \&c.

Holly he hath berries, as red as any rose,

The foresters, the hunters, keep them from the does,

Nay, \&c.

Ivy she hath berries as black as any sloe,

There come the owls and eat them as they go.

Nay, \&c.

Wliile Holly he hath birds a full fair flock,

The Nightingale, the Poppinjay, the gentle Laverock.

Nay, \&c.

Good Ivy say to us what birds hast thou,

None but the Owlet, that cries "How! how!"

Nay, \&c.

I think the bird here meant by a popinjay must be a peacock, which was a familiar object in the gardens of the great. In Scotland it was sometimes called "papejay" or "papingo." Chambers, in his curious book, "Traditions of Edinburgh," alludes to Lady Marie Stuart's "Household Book," wherein (with reference to the early part of the 


\section{Stray Leaves from a Border Garden}

seventeenth century) mention is made of a black boy and a papingo, or peacock, belonging to Lady Drummond. In the "King's Quhair" poem, however, a parrot seems to be meant, as also, in a poem by Sir David Lindsay, the woodpecker has been called the English Parrot, and also Popinjay. So he may be intended. In the West of Scotland shooting at the popinjay was a favourite pastime, and a wooden bird something like a parrot was used. This game is mentioned in Scott's "Old Mortality." There was an old French word papejay, in Flemish papegeai, in German papegeai, and in Spanish papagayo, always apparently signifying a wooden parrot. The popinjay is mentioned in an old ballad as one of the birds in the fairy garden whither the "Quene of Elfland" conducted Thomas the Rhymer. It was flying in company with the merle. Here I am inclined to think a peacock must be intended, since peacocks were sometimes semi-wild in noble demesnes. In our family we have poppinjays vert in the coat-of-arms, evil-looking, hawklike birds, resembling neither peacock, parrot, nor woodpecker; so I cannot decide the popinjay's identity to my satisfaction. I was amused once to hear applied to a young woman fond of gay but ill-assorted colours, "Oh! she's just a regular popinjay!" In connection with the story that it is the dainty woodpecker who is the "Real Popinjay," and not these our fierce heraldic birds, I have a dim memory of having heard how the Muses and the Syrens fell out, and the Muses getting the best of it, the Syrens were turned into woodpeckers. 


\section{CHAPTER IV}

\section{CANDLEMAS TO LAMMAS}

February 2.-To-day is the old Scotch Spring Term day ; it is also an old Church festival day. Both in the Romish Church and in the Anglican Church Calendar it is the Festival of the Purification of the Blessed Virgin Mary. It used to be celebrated by processions bearing candles and by the lighting up of churches. The word Candlemas is from the Anglo-Saxon Candelmaesse, and comes from an old Christian festival commemorating Simeon's declaration that Christ was a light unto the Gentiles. This in turn is said to have sprung from an ancient Roman festival held in honour of Februa, the mother of Mars, the war-god, when, on the night of February 2, people went about in procession with lights. Pope Sergius is credited with trying to sanctify this old custom by ordaining that Christians should offer their candles to the honour of Our Lady.

There is a curious old rhyme still quoted :
If Candlemas Day be dry and fair,
The half o' winter's to come and mair ; If Candlemas Day be wet and foul, The half o' winter's gane at Yule.

The old Scotch spelling of February was Feueryher. There was also an old Scotch custom called a Candlemas Bleeze, when a bonfire of whins was made and folk danced round it and made merry. In Jedburgh a big football match is still, I believe, played on Candlemas Day. "On 


\section{Stray Leaves from a Border Garden}

Candlemas Day, if the thorns hang a drop, you are sure of a good pea crop," says the old proverb, and likewise :

On Candlemas Day, if the weather be clear,

Corn and fruit will then be dear.

There is sometimes truth in these old saws, though they vary sometimes curiously in different places, and sometimes their variation may be explained by the alteration in the calendar. How curious it is to go gathering snowdrops, as I did to-day, in snow-boots, each delicate head dropping under a weight of snow, and when brought in to the fires, all recovering and looking fair and fresh as ever! "The Snowdrop in purest white array, first rears her head on Candlemas Day," says an old proverb, but she often comes sooner here.

February 14.-It is very interesting to see the buds beginning on the bare black trees; but oh, what a long time off the real Spring-time seems! There is a North-country saying, "Spring has not come till you can set foot on twelve daisies." I am afraid she is a long way off.

To-day is the anniversary of the Martyrdom of St. Valentine, said to have been such a woman-hater.

\section{THE SAD TALE OF THE MARTYRDOM OF ST. VALENTINE}

Come, pity St. Valentine, kissed to death ! They smothered his last reproving breath, Those laughing maids, with a wilful shower Of heavy-scented sweet orange flower, And red and white roses, such as blow In the land where Summer's dallying now; And then the decent and venerable manLooking as only a Bishop can-

They crowned with roses, 'mid lawless mirth, And hid away in the warm red earth, To rest (if he could) in an orange grove, Where nightly lovers were wont to rove; And to the silence a sweet love tale Was told by the amorous Nightingale ; They bid the Turtledoves bill and coo All round about him, for well they knew 76 


\section{Candlemas to Lammas}

'Twould make him turn in his lonely bed

To hear the love-songs he always fled.

And flying swallows to far-off lands

Told of his death at the maidens' hands.

March 8.- "Marchwind wakes the adder (ether), and blooms the whin."

A real Spring day at last, a little bite in the air, but warm in the sun. The snowdrops are over now, and the Primroses are fast starring the bank in their stead, pink, yellow and purple. The Winter Heliotrope (Tussilago fragrans) with its curious white flowers, is also out in abundance. I gathered the first Daffodil two days ago. I saw daffodils in the flower-shops as early as February 8, but they were forced. I like the old rhyme,

\section{Daffy down Dilly's come up from town}

In her green petticoat and her gold gown

The Rush Lily, or Satin Lily (Sisyrinchium grandiflorum), like a delicate purple Snowdrop, has been out for some days. There is a white variety I must get. The Siberian Pink Currant (Ribes) is in bud, and a few more days will see it out. There is a sweet-smelling yellow variety I must follow up. Tiny blue Periwinkles and two or three Violets have also been gathered, besides Crocuses and some early Polyanthus. The Jasmine nudiflorum in the kitchen-garden is slow to cover itself with its lovely yellow bloom. How curious it is we should use the Arabian name Jâsemum for Jessamine still!

The Spurge Laurel (Daphne Laureola) is out in the "plantin" now, with its curious little bunches of yellowishgreen flowers, and the roses are showing little green and crimson budding leaves.

March 23.-The crocus-bed in the Rose-garden is lovely with its different varieties of flower, and there is a tuft of white violets under an apple-tree. The squills in the kitchen-garden are in bloom. How the busy bee folk throng to the "Little Vesper-bell"! (the Italian word squilla also means a vesper-bell). Squills are said to be powerful 


\section{Stray Leaves from a Border Garden}

against sorcery; but how applied I do not know. The Chionodoxa, or Glory of the Snow, in the lily-garden is trying to bloom, but I fear the spot is too shady for it. I never see Chionodoxa flowers without recalling how a certain dear old lady used to say it reminded her of my Boy's eyes, they were so blue! I saw some lovely tufts in a neighbour's garden a few days ago, also some dark purple Iris reticulata and some mauve Daphne mezereon-Bois gentil, as the French charmingly call it. It is not infrequent here in quite small little gardens; the draper and the police-sergeant have quite fine bushes.

March 30.-A sudden snowstorm has shrouded all my budding treasures, Ay de mi!

April 4.- - Hail and snow showers have continued on and off till to-day, when it has disappeared from the garden, though it is still white on the Cheviots. I have gathered several bunches of violets, both white and purple, and the Dog's-tooth Violet (Erythronium dens canis) in the kitchengarden is out. It is such a pretty delicate flower, I should like to see it in masses ; it must be lovely, covering the railway cuttings, as I hear it does, in Vancouver. The creamcoloured variety is, I believe, more delicate than the commoner purple, but is prettier, looking, when well grown, like a little orchid. The dog-tooth, as well as other flowers, grows, I am told, profusely on Vancouver Island, but not quite so freely on the mainland, where, however, there are quantities of wild roses, Spiræa, Maidenhair-ferns, a kind of woodbine, and in parts, up the line of rail to the "Rockies," masses of bluebells, and the most wonderfully big and blue harebells. Near the glaciers some very tiny lilies, and rhododendrons on the mountain slopes. I wonder if these last are the same as the Swiss Alpenrosen? Cultivated flowers also seem to flourish very well there, growing big and beautiful.

April 29.-The gean-trees are in full bloom near here, but only beginning to show bloom in our precincts. They are very abundant in this place, and what I particularly like about them is that even a veritable baby tree will mount its 78 


\section{Candlemas to Lammas}

spring bouquet of bloom. I fancy the name is corrupt Scotch for the French guigne, word used for wild black cherry in Normandy-Guienne, as it used to be called. It is curious that Guindo is the Spanish for a wild cherry-tree. There are so many French words to be recognised in local Scotch - "gigot," which is gigot (leg of mutton) and "ashet," which, meaning "dish," has doubtless come from assiette, a plate. It is quite a study for those interested in words (see Glossary). The fruit-trees in the garden are in bud, and Greenfinches are very destructive of them. These birds seem very abundant this year. They are very pretty, but it is difficult to admire them when one sees the wholesale destruction of buds which goes on.

April 30.-The beds of hyacinths in the rose-garden have been, and indeed still are, a perfect picture. How I should like to go to Holland in hyacinth-time; it must be quite too lovely, the fields of bloom! But I am told that the smell is quite too oppressive ( $\mathrm{I}$ can believe it), and that the expanse of flowers is cut up by hedges for wind protection and canals for transport.

The yellow mahonia is now in full bloom, powdering the paths with gold-dust. Some people call this a Barberry; and I believe the mahonias and berberis are all akin. In Selkirkshire the barberry is called the Guild-treemeaning the Yellow-tree. In some parts of Devonshire people preserve the fruit in sugar, I believe in the same way currants used to be done in France, by dipping the bunch in white of egg and then in powdered sugar. I have also heard of it being made into a wine, rather like port, said to be very nice. I wish we had more berberis here, they are so pretty!

I visited the garden to-day of Dr. Stuart of Viola fame. I found there White Fritillaries in flower-how pretty they are!-also beautiful Auriculas, red and yellow Crown Imperials, which also had been most curiously dwarfed by frost, not, however, impairing their beauty in my eyes, and blue Greek Anemones. By the way, I have heard these are to be found wild in Bedfordshire, Herts, Surrey, and Berks. But I am inclined to think they can only be garden strays. 


\section{Stray Leaves from a Border Garden}

There were also palest pink Robinsonian anemones, double and single wood-wind, anemones (Sylvestris), concerning which I am of Parkinson's mind, that they are "so dainty, so pleasant, and so delightsom flowers that the sight of them doth enforce an earnest longing desire in the minde of any one to be a poffeffour of some of them at the leaste." Also many varieties of daffodils, notably Emperor, Empress, and Maximus, blue gentians, and St. Brigid anemones. Curiously enough I have never found woodanemones in our "plantin," though they grow freely in woods not far from here. There were various violas just beginning, and Dr. Stuart has succeeded in producing one with a sweet smell, which is very delightsome, besides a most interesting collection of Alpines and some quite tiny daffodils, one I remember called Angel's Tears (Triondrus $a l b a)$ I think. The story goes this name was given because the little peasant-boy who gathered wild-flowers in Spain for Barr's collector was found in tears because he could not reach a certain fine tuft of this dear little daffodil ; it grew in such an inaccessible spot poor little "Angel " could not attain to it.

The beautiful and uncommon Columbine (Aquilegia Stuarti) we owe to Dr. Stuart, and for that alone I think he is due an "unco" debt of gratitude. His name is well known to flower-lovers, and his dear little garden, full of so many delightful things, is a joy to visit. His Crown Imperials, trained up against the house under the windows, were very effective. I like the old legend of the Crown Imperial, the Royal Fritillary, as I have heard it called, which declares it grew by Lazarus' tomb, and some of our Lord's tears fell upon it. Hence the drops of crystal clear water, or rather honey, it cherishes and never parts with. I think it must have been more popular in old-time gardens than it is now. Old Parkinson, Queen Henrietta Maria's gardener, praises it, and there is a delightful picture of it in one of his books; but one does not often see it in abundance in modern gardens. The finest specimen I ever saw wàs in a comparatively modern 


\section{Candlemas to Lammas}

Devonshire garden, where a plant of the yellow variety flourished in the angle of a buttressed garden-wall, sheltered by overhanging thatch, looking to the south, and had most lovely spires of bloom. I fancy it does well in Devonshire. I have heard of it being sold in bunches in the marketplace of Taunton. Was it among the flowers the Fair Maids of Taunton threw before the ill-fated Duke of Monmouth, I wonder? Perhaps its unpopularity is due to its association with Taunton and the sad fate of the Fair Maids. Or it may be only to its very peculiar scent, somewhat foxey, and to some people quite what the old herbalists called "a naughty smell." I believe it is called Crown Imperial because its seed-vessel is supposed to be like the crown of the Emperors of the East. Certainly it is one of the loveliest of old Mother Nature's seed-boxes-Mayday. This was the old Roman feast-day of the goddess Maia. It was delightfully called by our prosaic Saxon forefathers Trimilki monath, as at this date they began to milk their cows three times a day.

A few days ago we found a robin's nest on the ground among the branches of a thinly-branched rhododendron by the path. The little bird sat unmoved on four dear little speckled eggs, and did not seem to mind our passing to and fro. But, alas! to-day her murdered little body has just been found lying by the nest. Evidently she had fallen a prey to some of the many cats which haunt this place. We have tried an experiment. The yet warm eggs have just been transferred to the nest of another robin, which is better concealed in a heap of brushwood on the tennis lawn. I wonder how this will succeed.* I think Robins are such dear little birds. It is curious how there is quite a British feeling of friendship with the robin, and his nest is seldom harried. The poets have been his friends from time immemorial, from the early days of the "Babes in the Wood," whose little bodies the pitying robins covered with leaves, to later days, when Blake with a

* We found this nest later quite empty, so we hope they all hatched out. 


\section{Stray Leaves from a Border Garden}

sweet conceit said, "Robin in a cage sets all heaven in a rage" ; and Thomson, our own Border poet, describes him so delightfully coming to be fed. in winter. I wish there was the same feeling in France, alas! for the strings of ronge-gorges I have seen hanging at the poulterers. Our wood is beginning to look pretty, with its bursting beech-leaves and chestnuts, and the sweetbriars already scenting the lane. I like Shakespeare's name for it, Eglantine, from the French aiglentier, I suppose. In some of the old Border ballads it is called Eglenterre. John Brainard, an American, sings sweetly of the "humble sweetbriar, the little four-leaved Rose that grows along the poor girl's pathway by the poor man's door." Old writers say it promotes cheerfulness, so I have planted it by the house. It is said to make a fine wall climber. I have a small bush in the Rose-garden, and after rain it smells quite strong.

There is a legend the thorns point downward, because the devil cursed them. When Lucifer was cast out of heaven, it was said he tried to return by making a ladder of sweetbriar. But he failed, as it was only allowed to grow into a bush, and no higher. The woodruff is showing, and the barren strawberry (St. Hilary's berry), and many coloured primroses were with us before Primrose Day. Prime is an old Scotch word for the Spring, and I like Prior's explanation of the word "primrose," that formerly it was called Primerole, from the French primerole, from the Italian primeverola, the tender diminutive of primavera, from Flor di primavera, first Spring flower, the first ambassador of Spring. We have the most delightful variety of coloured Primroses here, all wild; all shades from purple, lilac, buff, salmon, crimson, pale pink, and, of course, the ordinary yellow, which I almost think the prettiest. In the grounds of an old house (Wedderburn Castle) near here they were planted in a diamond-shaped pattern

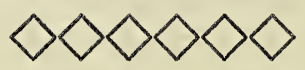

on either side of the avenue of beech-trees, and did look so pretty in the border, like enamelled bars on the dark 


\section{Candlemas to Lammas}

earth. No blue ones, however. I do not care much for these modern blue ones; they incline too much to magenta and purple to please me. I believe, however, I am wrong in calling the Blue Primrose modern. I think it is only a revival.

How pretty the lane is when the thorns are in bloom! And down by the river, on the common, the old gnarled hawthorns are so picturesque, all crooked and full of birds, who take flight when the milkmaid comes along and calls the black cow and her fellows into the shade to milk them. In Ireland hawthorns are called Fairy Thorns, and it is unlucky to cut them down. There is an old saying, which runs, I think, thus :

\section{Maid who on the first of May Goeth a-field at break of day, Wash thy face in dew off the hawthorn-tree And ever after a fair maid be.}

I am making a new little rockery in the kitchen-garden, in an angle of the wall by the red Victoria plum-tree. I have got some pretty blue creeping veronica on it, and a "lot of little things," but I shall get some more when I go to the mountains of Auvergne. I think it will be rather a success if only the rats will leave it alone, but they seem very fond of investigating rockeries. I found to-day my little bay-tree in the Rose-garden all wilted, and looking quite dead. There was an old-time belief, Italian I think, that the withering of a bay-tree meant disaster. I hope it does not in this case. Shakespeare makes an allusion to this belief in "Richard II.": "Tis thought the King is dead; we will not stay; the bay-trees in our country are all withered."

\section{June 10.-Mont Dore-les-Bains, Auvergne. I have just} come in from a visit to a most quaint little garden here, a series of tiny terraces on a steep hillside, where an old photographer with a taste for botany or "wort-cunning," as it was delightfully called long ago, has collected with patient perseverance specimens of the flora of his native mountain 


\section{Stray Leaves from a Border Garden}

valley. Mont Dore-les-Bains is a foreign thermal spa with a history, which tells how the Romans used to bring sick troop-horses to be cured of illness there when the legions were colonising Gaul. Thirty years ago it was almost an unknown spot to Britons. I remember when the sound of our English talking made people turn in the street of the little dingy Auvergnat town to look at the foreign barbarians. Now the renown of the virtues of the healing springs of Mont Dore have so travelled that all nations flock thither; men and women of many nationalities may be met with, drinking at the Wells in the valley or wandering in the pinewoods that clothe the surrounding mountains, gathering dewberries, wild strawberries or whortleberries-myrtilles, as the natives call them-or making bouquets of the upland wild flowers, golden arnicas, harebells, violets, and gentians, and sweet sultan. One couple we met often carried a tame white cockatoo and let him take flights in the fir-trees. Whortleberries are called Hurtberries in some parts of England and, I think, in old days, on the Border, though Blaeberries seems the present Scotch name. The old Swedish was, I believe, blabaer, and the Icelandic blaber. Bilberry is, I think, the English common name, while the American Huckleberry is an old English name. The German name is Heidelbeere.

In Devonshire I was told great quantities are yearly shipped from the Tor country to Bordeaux to be put into the red wine. He may believe this who likes! I certainly never saw larger and finer berries than among the Tors. Blue Corn-flowers (Cyanus) grow very freely here in Auvergne, and indeed have been adopted as the floral emblem of the place; they are painted on the glasses sold to the waterdrinkers, and on the varied souvenirs for sale in the little booths in the public park. The large blue Centaury too grows in abundance in the fresh meadows, and a lovely brown Geranium, Pheum, as well as a blue one called, I think, Sylvaticum, similar to the Blue Geranium of the Scottish Borderland. There are several very pretty species of Gentians, two blue, one of which is autumn-flowering. 


\section{Candlemas to Lammas}

Autumn Bells is a pretty old name in England for this last, but bouquets of these are disappointing, as the flowers close when in water. Yet the tints of plants found on mountain soil are so much more vivid in colouring than those of the same kind of plants at lower altitudes, that one is tempted to pick in spite of oneself. Beautiful, however, as is the Gentian, I have not come across much praise of it by the poets, though William Cullen Bryant sang of the "fringed gentian's sweet and quiet eye." There is a splendid tall yellow Gentian which grows freely on the hïgher pastures, and looks very handsome both when in flower and in seed-G. lutea. It is, I believe, used in commerce as the "tonic gentian." Fellwort (or Mountain Plant) was the English name in use in Queen Anne's days; the term "fell" still lingers on the Scottish border and in the British Lake Country, and an old Scottish name for Birdsfoot Trefoil (Lotos corniculata) used to be Fellbroom. Crawtaes is its more recent Scotch name, also Catsclaws. Milton also called it Crowtoes. Crowtoes is sometimes applied to Bluebells.

In the Rose season Cabbage-roses grow in every peasant's untidy patch of garden and by every evil-smelling crassly dirty hovel, and well do I remember a withered old "alte Hexel" of a woman who always came after me with her basket full of sweet temptation, once she discovered we could not resist buying of her daily, to make potpourri, since Cabbage-rose leaves are the best for that delectable mixture. Indeed, once she nearly came to blows with another old white-capped wife, who had been beforehand in offering us her Roses. I found in my old man's garden different kinds of Mountain Pinks-Sylvaticus Coesius, \&c. - Saxifrages and Martagon lilies, Astrantia, and a lovely yellow-flowered Aconite; also a curious feathery-green plant called Cerfenille musquêe, or musk-scented Fennel, very graceful and suitable for a wild garden, but requiring a good deal of elbow-room, as it spreads into a great bush. I shall take specimens of all these away to Scotland and try them in my garden. In the meadows the giant globe- 


\section{Stray Leaves from a Border Garden}

flower (trollius) is abundant ; one can gather perfect sheaves of it. I know this will grow with me, as it is still to be found in some parts of the Merse, where it used to grow wild in abundance, and was called Stocks, from a fancied resemblance to a cabbage-stock. In Wiltshire I think they are still called May-blobs. Allan Ramsay, that quaint old poet, calls it the Luckengowan. "Lucken" means "shut" or "locked up," and "gowan" is the old name of Caltha palustris, the Marsh-Marigold, so the derivation of Luckengowan is clear. In Iceland the Trollius is called the Troll's-flower, and it is said the evil-minded trolls go at night and unlock the Luckengowan and drop poison into its cup to poison the dairymaids and herdsmen. An old name in Herbals for this flower used to be Troll-flower and Cabbage Daisy.

June 22.-I never was one of those people who rave about the superiority of Alps over flats, but still there is a great beauty about a lush emerald-green valley set in a high setting of grim mountains clothed with beech and fir woods. Under the fir-trees, with their festoons of grey moss (I fancy it is the same species of Old Man's Beard that hangs the trees in the Southern States), in just such a valley by a tumbling mountain beck, the Dore, with the low green whortleberry bushes all around, with scented white orchis and masses of golden creeping broom, I was sitting, looking at the blue distance and across to the great mountain in whose flanks yawned the dark craggy cleft of the Val d'Enfer, listening to the faint far-off bells of the cows and goats. "What a halcyon day!" I said. "Do not say so," rejoined my companion. "Halcyon days are said to precede storms!"

It was Jubilee Day in Britain far away; loyal bonfires were dying down all over England and Scotland, and on the Border our poor little old mansion-house was burning, a victim to its own loyal illumination; uprising flames, falling timbers, frightened birds forsaking the old ivied walls, shouts, despair, and wild confusion. Folk at a 


\section{Candlemas to Lammas}

distance deemed it an " unco' big bleeze " (meáning a bonfire), as they said afterwards. And then what desolation! mouldering heaps of contorted rubbish, charred rafters and stones littering the once pretty Rose-garden, and nothing beautiful amid the ruins except a bed of rush-leaved Iris uplifting their graceful blue heads, not a whit the worse for all the turmoil. Seen framed in the ghastly gap in the wall caused by the total disappearance of the drawing-room bay window, it was Peace in the midst of Ruin. Then came the builaers to rebuild the wrecked nest, with all their noise and dirt, lime-heaps, chips, and cartloads of unsightly material dumped down anywhere. Yet the birds came back to the ivy and fly in and out of the empty windowframes. Curiously enough, I remember hearing that, when the Opéra Comique in Paris was burnt, little cries were to be heard amongst the ruins, particularly at nightfall. These were the small birds who returned to their nests after the fire, and were only driven away as the clearing of the ruins proceeded.

May 30.-Whit Monday. I have never seen many gipsies about here, and their delightful carts hung with basketwork do not often come this way. But still there are Border gipsies away in the Cheviots, and to-day, hearing there was to be a king crowned amongst them, some of us cycled over to see the coronation. I could not go, but this is what they saw, as described by one of the party: "The little village of Yetholm, which is picturesquely situated amongst the Cheviots of the borders of Roxburgh and Northumberland, was the scene of an unusual stir and excitement on Whit Monday. People from all the Border country round assembled in thousands to .witness the coronation of the King of the Gipsies, which ceremony took place at noon on Yetholm Green. Yetholm consists of two villages, Town Yetholm and Kirk Yetholm, separated by a valley, through which runs the Bowmont Water, a tributary of the Till. On Monday the weather was all that could be desired, and the village on the hillside was steeped 


\section{Stray Leaves from a Border Garden}

in the most brilliant sunshine. The roads, ever since early dawn, had been black with an endless stream of Whit Monday sightseers-the greater number of them on bicycles, of which there must have been several thousands. Kirk Yetholm is the gipsies' own particular village, in which they have had an encampment for nearly two centuriesever since a bit of land was granted to 'William I.,' of the royal line of 'Faa,' by Sir William Bennet, in gratitude for his services. I wonder what kind of services! The gipsies are generally believed to have come from Egypt; indeed, they are commonly called Egyptians, which name they are said to prefer. Their name for themselves is Romany (from the Sanscrit Rumamus, meaning "strong man"). They themselves claim that the surname of Faa or Faw, an ancient one among them, is derived from Pharaoh. But, from a curious likeness between the Romany and Hindustani languages, some authorities, among others Sir Reginald Burton and Grellmann, imagine them to be of Hindoo origin. The old English term for a gipsy was Gyptian, and the Hungarians sometimes call them the children of Pharaoh (Pharaonepek). In Hindustani the word 'snow' is hima, and the word 'bearer' is laya; in Romany the words are him and loya. In both languages the word 'Himalaya' means the 'bearer of snows.' The gipsy word Raunie, which means a chieftainess, and which has been adopted by the Scotch under the version 'Randy,' a scolding woman, is just the Hindustani Ranee, lady, queen, or woman. The Scotch word 'sorn,' to obtain food forcibly, is said to be a corruption of the gipsy choar, which is from the Hindustani choma, to steal. Indeed, it would seem pretty well proven that the original home of all gipsies were the slopes of the Himalayas, at least before 1417 , which is the time they seem first to have attracted notice in Europe. I have heard that in Hindustani the word ghudda is used for a donkey, and Jamieson, in his Dictionary, seems to think the Scotch word 'cuddy' (donkey) may be just a corruption of the gipsies' term for their favourite beast of 


\section{Candlemas to Lammas}

burden. The Hindustani kistie, for a chest, is also among them. Gipsies, however, when talking to strangers, are very reserved, and avoid as a rule using Romany words ; and if by any chance a word or term should escape, they do not like being questioned on the subject by a Gorgio. The earliest notice about the gipsies in Scotland is a curious old letter of King James IV., dated 1506, recommending Anthonius Gawino, Earl of Little Egypt, to the King of Denmark, as the gipsy chief was about to visit Denmark; while King James V. made a treaty of friendship with 'John Faw, Lord and Earl of Little Egypt.' But, as might be expected, the gipsies did not long retain Court favour. Among many different small ways of gaining their livelihood, the gipsies used to make the horn spoons once so commonly used, and were in consequence called Horners. Horn spoons tipped with silver are sold as Scottish souvenirs in Edinburgh at the present day.

"“'Wull' Faa I. died at Coldingham, leaving twenty-four children. His subjects carried his body back to Kirk Yetholm in state, with a mighty escort of donkeys, and buried him near his 'Palace' in the Cheviots. The succession of his son William was disputed by a man who was known by the unpleasing nickname of the 'Earl of Hell,' but this usurper was defeated in a battle on Yetholm Green, and Wull Faa II.'s authority successfully established. During his reign the tribe lived chiefly by smuggling, which pursuit they found very profitable, like their brethren in 'Guy Mannering.' 'Wull' Faa II. died in 1847, at nearly a hundred years of age, and was succeeded by his brother-in-law Charles Faa Blyth. Charles was well known to Sir Walter Scott. His reign was a short one, and when he died his son David declined the sovereignty, so the daughter of Charles I., the late Queen Esther, who had married a Rutherford, succeeded her father. The title has remained in abeyance since her death, which occurred some years ago, till it was revived last week by the coronation of her son, an old man of seventy, as Charles II. The new king and his wife have kept an inn at Yetholm since Queen 


\section{Stray Leaves from a Border Garden}

Esther's death. The prime mover in the restoration of a king to the gipsies was the parish minister, Rev. W. Carrick Miller, by whose exertions the function was got up. The proceedings were curious and amusing, in spite of the feeling of mockery about them. A small low platform, upholstered in red and yellow, and draped with flags, was erected up against the gable end of the Old Border Inn, and on it were placed about half a dozen chairs and a small round table, with a red velvet cushion for the crown. There was a small enclosure of reserved seats round the dais, consisting of planks, and they were soon crowded, and also the neighbouring cottages, from which a good view could be obtained, were covered with men sitting astride of the roofs. The first dignitary who appeared was the 'Lord Mayor' in the regulation scarlet and fur and big (brass) chain of office. Then came the Court (otherwise the Committee) in 'character,' and they were received with a great deal of laughter. Their clothes looked as if they had been supplied by a circus, and were of the most motley description. There was a man-at-arms in tin armour, a Robin Hood in Lincoln green, or more probably, a Scottish archer; Harry VIII., a cowboy; heralds and halberdiers in tinsel and velvet, and many others whose costumes were less easy to identify. At last the minister appeared in silk gown and trencher-hat, and after the assembly, at his invitation, had sung two verses of the Hundredth Psalm, to the accompaniment of the brass band from Coldstream, he opened the proceedings with a prayer, and then made a short speech welcoming the gathering to Yetholm. A brief address followed from Bailie Gibson on the history of the gipsies in Scotland (the more sympathetic that he, like the minister, is supposed to be akin to the Romany 'chals'), then the band played 'Rule Britannia,' and two heralds, in marvellous costumes, read aloud the Proclamation sentence by sentence, the one repeating it after the other. It began, as befitting a Royal Proclamation, with 'Oyez! oyez! oyez!' and it set forth that it having been found that the ancient people of Little Egypt 


\section{Candlemas to Lammas}

were becoming scattered for want of a leader, they had declared for a king, lest they should become a forgotten race, and having considered the hereditary claims of Charles Faa-Blyth, they had agreed that he should be crowned King of the Yetholm Gipsies with all the honours due to a prince of royal gipsy blood. 'Challenge who dare!' The Proclamation did not go unchallenged.

"After the laughter and cheering which followed the reading had subsided, Mr. Miller read aloud a letter he had just received, signed 'William Blyth,' protesting against the coronation of Prince Charlie, and claiming the crown for the writer, whose father was a son of the late Queen's brother David-the man who had not taken up the title. There was an exciting pause while the minister called upon any one to come forward who challenged King Charlie's right, but as no one came, the 'Archbishop' was summoned 'with all convenient speed,' and the band played 'Who'll be king but Charlie.' At this supreme moment the King arrived. He entered the enclosure with some difficulty, for his team of six donkeys suddenly became seized with obstinacy and refused to move! The rôle of Archbishop was filled by the village blacksmith, bareheaded, and attired in his working clothes, with his sleeves rolled up. He stood waiting with the crown (made of brass, and studded with large imitation stones) till the King made his way to him, when he placed it on his Majesty's head and made a short speech in Romany, of which the closing words were 'Long live King Charles!' The people cheered merrily, and the old King, standing up in his regal robes, with the crown on his head, waved his shabby cap and looked supremely happy. He then mounted the donkey chariot again, in which his Queen (wearing her crown) had remained during the ceremony, and the grand procession was marshalled to parade through the village, preceded by two halberdiers, and closed with a 'miscellaneous following,' as the programme put it. Their majesties held a Levée in the afternoon at their 'Palace' (a little whitewashed cottage); it was well attended, 


\section{Stray Leaves from a Border Garden}

and the day was further enlivened with a public dinner, sports, a selection of music, and Highland dances from the Buccleuch Pipe and. Drum Band. A grand ball in the evening closed the proceedings, which are memorable, as it is not likely anything of the kind will be seen again." For kind permission to reprint this I am indebted both to the writer and to the editor of the Border Magazine, a nice little periodical which takes note of Border worthies and Border local topics.

Sir Walter Scott, in his fascinating "Minstrelsy of the Border," notes that it was a common belief that gipsies had the power of throwing upon bystanders a spell . . . to make them see the thing that is not. This is alluded to in the old ballad of Johnnie Faa. He further tells of a gipsy who so bewitched a number of folk near Haddington that they deemed they saw a barndoor-cock dragging a big oak-tree. A man passing with a cart full of clover chanced to pick out a sprig of four-leafed clover, when the glamour was removed from the eyes of the onlookers, and they saw the oak-tree to be but a bulrush. Similar tales of gramarye are told of the Indian conjurers.

\section{NEW YEAR'S EVE.-CAROL.}

I cannot sleep, the sound of distant bells

Fills all the air, and bids me look abroad;

The Year is flying, fleeting from our earth,

To the far heavens by a star-strewn road.

He hath the horses of the resting Night,

" Grey Cloud" and " Stormwind," speedy in their tracks.

I see his hair streaming like lightning bright,

I hear the echo of the song he sings;

A weird lament for all the prison'd souls

He bears behind him in his sleigh from earth;

A wail of sorrow for the empty hearts

He leaves rejoicing at a New Year's birth.

Yet are there tears shed in this idle world, Because the Year to us at last is dead;

I see them on his mantle shine empearled,

I hear the sighing borne upon the wind,

I see high heaped the sleigh with broken hearts,

Reft joys and dead delights that came to some,

Day-dreams of youth, the sadder dreams of age,

$\mathrm{He}$ gathers all, for he is going home. 


\section{Candlemas to Lammas}

Around him flock the Angels of Mankind, The Guardian Angels bid the year farewell, Like flying swans against the sky outlined, Or falling snowflakes, to dull mortal eyes.

Dark is the night spangled with peeping stars, Yet by the lantern in his hand methinks, Though flecked with snowflakes, in the sleigh I see.

Roses and lilies, and sweet-scented pinks, Flowers and buds, the hearts that bloomed and died.

Sweet April hopes on whom no summer smiled, Tendril and leaf, desires sorely tried,

And mellow fruit for garners in the sky.

Lammas means the "feast of first-fruits," and is the Anglo-Saxon Hlaf-masse; "Hlaf" meaning loaf of bread, and "masse" feast. Now it is merely connected with certain rent collections. 


\section{CHAPTER V}

\section{THE CHRISSENMAS TO MAYDAY}

AT last a year has passed away, the house is built, the old thick ivied-walls have new partitions, a new more modern roof has replaced the old one with the moss-grown crow-stairs, and the birds may welcome back now any day of the opening autumn the hands that were wont to feed them in the winter. Oh! the despair of seeing the environs of a house ever look nice after workmen have been about. What evil relics of rags, paper, chips, stone, spars, iron, broken shrubs, trodden plants, rockeries buried under rubbish, they seem to choose such spots as preeminently suited for rubbish deposits, paths trodden "where nae paths suld be," destruction done apparently for pleasure. It is well that Winter should soon cast a pitiful white veil over it all till Spring comes with her revivifying wand to touch the outraged beauty. I think one's only consolation for the long weariness of the winter is the looking forward to the spring, and what the people do in the countries where a really long winter prevails I cannot think. President John Adams is said to have wished he were a dormouse, to escape the bitter New England winters.

I should hate to live in North America or Scandinavia, I am sure. I was reading rather a pretty book the other day about curious Russian folklore superstition, called "Russian Folk-Tales," by W. R. J. Ralston. One legend I Frticularly liked, the tradition that during the evenings 


\section{The Chrissenmas to Mayday}

which elapse between Christmas Day and Twelfth Night the Infant-Saviour wanders on the earth, and also that on Christmas Eve and Epiphany Eve the gates of Paradise are thrown open, and on the earth all the frozen springs and rivers run with healing wine, and the bare leafless trees bud and bloom. The peasants, particularly those of Little Russia and White Russia, sing what they call Kolyadki or Christmas songs. The term for Christmas Kolyadka is said to be derived from the Roman Calendar, and the Christian festival was grafted on an old-time festival in honour of the Sun, called a goddess, and worshipped with dance and song. The following is a sort of specimen of these songs I wrote on one of these legends :

\section{THE DYING CHILD}

Hark ! little Mother, the rain beats wild, See the snowflakes flying across the sky,

Is $\mathrm{He}$ out in the storm, the White Christ-child, Hast seen Him yet, Mother, passing by ?

O Duschinka, work no more this e'en, For Father Kouzma says 'tis a sin

To work when the Christ-child may be seen, For we should be watching to ask him in.

He wanders o'er earth at Christmastide, When the red sun sinketh in the west;

Over land and sea, and far and wide, Calling the sufferers to their rest.

My bones are aching, and so is my head, My cheeks are burning, my eyes are dim;

I am so weary, I wish I were dead-

Oh ! I wish to-night I might see Him !

The wind howls wider, the door flies wide, In the blackness of night is it snow shines white?

Little Mother, what do I see outsideThere, out in the pinewood-a golden light?

Say, is it the moon that shines so fair

Or the red sun peeping thro' black tall trees,

Or the silver stars I see shining there?

I hear the far sound of the summer bees,

I smell the scent of the limetree flowers,

I see the brook running free as in Spring,

Where I remember, in happier hours,

"The Birds of God" * upon the wing.

* Swallows. 


\section{Stray Leaves from a Border Garden}

It is running dark with blood-red wine,

$O$ give me to drink of the healing stream,

The stream that cures the aching head,

O say is it Paradise or a Dream?

By the sweet waters, o'er the green plain,

Gold apples of life in His open hand,

Cometh the Christ-child to ease my pain,

He calls me away to the Heavenly Land.

Jamuary 26.-Gathered to-day the very first snowdrops, only half a dozen, small and very short-stalked. Praise to Priapus, God of Gardens. Something at last! I heard the other day they were called Fair Maids of February, because the maidens who walked in the Candlemas processions used to wear white, and decked the Virgin's altar with snowdrops.

February r.-The snowdrops now cover all the southern banks, and do look so funny with patches of snow interspersed. I like the quaint German name for them-Schnee Glöckchen (Little Snowbells); the French name is Perceneige. The legend of the Snowdrops is so pretty, I must just note it here, I think :

Upon the dreary unknown wild,

Mourning her fate, by Sin beguiled,

Eve cowered, 'neath the driving blast,

Wretched and homeless, poor, outcast.

The whirling snowclouds hid from view

The Paradise that once she knew

Where she no longer might remain.

Her white soul was not free from stain.

Yet when in fulness of her grief

She prayed far Heaven to send relief, A mighty Angel stayed his flight, Abroad, upon the wings of Night, And bending o'er her prostrate form, Gathered some snowflakes of the storm, And bade them flowers become, to show That she despair no more need know:

"Pure as these snowflakes," then said he,

"Shall you again, O fallen, be,

Not always shall you outcast wait, Sin-stained before the sealèd gate."

He spake, and where his foot had trod A ring of snowdrops starred the sod. 


\section{The Chrissenmas to Mayday}

February I4.-To-day was the most delicious Spring day. February Filldyke is belying its name. Unless February is wet, it does not seem satisfactory to farmers however, so I am alone in my rejoicing at this delicious weather. It is a real St. Valentine's Day, especially down by the little brown river, where the dainty black waterhens were haunting the banks and making sly predatory investigations through the beech-hedge into the kitchen-garden, after cabbages, I suppose. The snowdrops are thick throughout the "plantin"; they look just like snow, now it is all gone. I gathered a boxful to-day and sent them to a soldiers' hospital, where I know they will be appreciated. I remember how pleased the sick soldiers used to look if I happened to have any button-holes for them, or a posy for the Ward-table on visiting-days :

Children, St. Valentine haste to greet !

Let us hurry down the dull muddy street,

For now we shall find the wayside grass

Besprent with daisies where'er he pass.

The Lambs to each other call and say,

"Now cometh St. Valentine this way.

His crozier wreathed with the earliest flowers

Born of the first two sunny hours."

The kind old Bishop! 'twas said he smiled

Whenever he met a little child.

He called them buds of the human race,

The Bairnwort that glads each poor worn place.

Around him a train of little Loves

To keep in order a flock of Doves

That circle him on silver wing,

And luck to lovers, who see them, bring.

On banks behind him the gorse is gold,

Before him have fled the snow wreaths cold,

The sky is no longer dark and grey,

The Loves have swept all the clouds away.

Then one small Love a sparrow's egg breaks,

And a catkin brush he then quickly takes

And paints the sky a beautiful blue,

Perfumes the air at the same time too,

St. Valentine smiles and says," Well done!"

And goes away thro' the woods alone,

That wake and bud as he passes along,

While the Birds in greeting sing him a song.

I took a careful detailed inventory of the contents of the 


\section{Stray Leaves from a Border Garden}

kitchen-garden borders to-day. I found four coloured primroses, three yellow ones, and two sprays of the lovely yellow-stars of the Jasmine nudiflorum, which somehow does not seem to flourish on my wall with western aspect. In some places it is so lovely; I remember it a perfect "wig" over an old doorway in a Yorkshire garden. Finally, I visited the clumps of Winter Aconite, and found six little golden befrilled flowers. I think they look like tiny flower fays with their green ruffs. They are pretty, too, in seed. I do not like their name of Wolfsbane, it sounds such a wicked name for such little Dears. I also found a sprig of Arabis. In Sussex it is called Snow in Summer and Snow-on-the-Mountain. Mine grows in amicable union with a cushion of Wild Strawberry. They look so pretty together! Then I paid my usual visit to the greenhouse. It is very small, but invaluable as a tonic when one's spirits are depressed by long continuance of cold and bare flower-borders. It is so delicious to come in to it on a bitter cold day, such as we had last week, and look at each pot, from the magenta-flowered Cactus to the dear little fly-catching Dionea muscipula, a sort of glorified sun-dew. I love scented Geraniums too, the pepperminted scented, oakleaf apple, and all the tribe, even the now despised Pelargoniums, beloved of the evil greenfly. But how well these last do grow sometimes in cottage windows; they make me quite envious. The receipt, as given by an old cottager, "Never open the window on them, and put them out when it rains."

I find the dear little Hoop-petticoat Daffodils (Bulbocodium) are easily grown in the greenhouse, and last a long time in flower in my colder sitting-room. They always remind me of the place where I saw them first, wild in a damp field near Biarritz, looking so pretty, like golden dots in among the green herbage. The tiny Rush Daffodil Jonquil is also very nice in pots for the house; 'Tulips and Roman Hyacinths, of course, no one need be without. The “Angels' Tears" Daffodil is also quite possible. I grow Sarracenias, or Side Saddle flowers-Huntsman's Horn 


\section{The Chrissenmas to Mayday}

some people call them-but, of course, just now they are not very ornamental. How lovely they must be in their native Canadian swamps! Snowdrops, though they won't force, can be lifted out of the border the moment they show their heads, and then last a long time in pots in a room that is not too hot. I have heard of Crocuses being grown in hyacinth glasses with water. I must try this; it sounds pretty, but impossible. At present, I only grow "Joss Lilies," Polyanthus Narcissi in water, and, of course, Hyacinths, in glasses, for I am old-fashioned enough to grow hyacinths in blue and green glasses. Doctors differ about the best mode of procedure after the bulb has undergone solitary confinement in the dark for upwards of six weeks. I always find that not changing the water, except in such small modicum as comes from keeping each glass filled, seems to succeed well. A small bit of charcoal lives at the bottom of each vase and keeps all fresh and sweet. Certainly the results are beautiful. I buy my bulbs of English providers, generally of a man named Sydenham (Tenby Street, Birmingham), who sells all kinds of bulbs, and I do not think they could have more lovely flowers, even the second year planted out they are beautiful. A Bermuda Cedar, about two feet high, is a lovely room decoration, and so is a Life Plant, a Myrtle, or a Eucalyptus. Coix Lachryma, "Job's Tears," is also a pretty room plant. But I must admit these do not stand long visits to the house, and have to retire periodically to the greenhouse; when Boy comes with his little cart, and they are solemnly packed side by side and carted away in state by Master Redcap. I think a greenhouse can be so pretty. I wonder no poet, except Cowper, to my knowledge, has ever sung its charms ; but, then, there must be taste in the grouping of the flowers; not dull rows of plants all the same, like a regiment. Even a regiment of Tuberoses or Carnations can be dull. People are trying now, I believe, to grow Orchids on tree-fern stems instead of always in wire-baskets. It will look much prettier, and will probably be a success, since the more the tree-fern will rot the better the parasite 


\section{Stray Leaves from a Border Garden}

will like it. I believe this method is often followed in Australian greenhouses. There is an interesting new theory -French, I believe-that it is a good thing in summer to paint the glass roof of your greenhouse reddish-orange, as this stimulates the plant-growth, but prevents them being burnt up by the sun, and is as good as blinds. It is not supposed to be good to paint it white, or green, or blue ; indeed, blue is said to kill the plants. There is a most interesting greenhouse near here containing a mighty myrtle-tree, grown from a sprig of a young lady's bridal bouquet in the last century, I think. It grows so, the roof has to be made periodically higher for it.

The last time I saw it, I was asked to admire how beautifully it was cut : exactly like a monumental cypress! Tastes differ. I sighed inwardly as I thought of the branching luxuriance Mr. Myrtle would have shown in his native land.

February 16.- The Roses have tiny red and green leafbuds on their bare stalks, and the Ribes is beginning to think it is indeed Spring at last, and the ground is all carpeted with St. Patrick's dear little cabbage, while the nut-trees are showing a few stray "lamb tails"- - Hazel Palms, as they are called on the Border, perhaps from the old custom of carrying branches to church on Palm Sunday, which prevailed on the "English side." There is a delightful Scotch superstition that if you find a cluster of nine nuts, called a " ninesome bobbin," you should dream on it, as a Love charm.

I always think of the Queen of Spain's daughter when I see the nut-trees in bloom all along Church Walk, as Boy calls the path where they grow so freely, because by it we go to the little old church on the hill the "Kirkis of Foghow."

\footnotetext{
I had a little nut tree, Nothing would it bear But a silver nutmeg And a golden pear. The Queen of Spain's daughter Came to visit me, And all for the sake of my little nut tree. 


\section{The Chrissenmas to Mayday}

This Queen of Spain's daughter is said to have been Joanna of Castile, who, with her husband, Philip the Fair of Austria, visited her sister, Katherine of Aragon, in 1505 , at Windsor.

This old nursery song was illustrated in a charming manner by Walter Crane, showing the princess of Spain in a mob cap and a lovely orange brocade, and the singer as a dear little rustic maid in a lilac sun-bonnet. By the way, there are still sun-bonnets, lilac and otherwise, to be seen on our Border in summer-time, and also worn by the women in winter when sorting potatoes in the bleak windswept fields. How pretty a nut alley is! I know an old garden where there is a lovely verdant bowling-green sheltered by a nut alley so old that the trees arch over one's head, and one can quite imagine plots for the restoration of the well-beloved Chevalier being laid in its seclusion. The hazel, used as a divining-rod for water, is now becoming well known on the Border, but it was not so formerly. I have several times known instances of travelling diviners coming this way from the South, and it is not so very long ago that the diviner had to be introduced on the sly, to save him, and likewise his employer, from being torn in pieces by the indignant country folk, who declared that all such persons must be emissaries of the Devil. There is no doubt the wand does turn in the hands of some people and not with others, but hitherto there is no real explanation of the wherefor. Holly, willow and thorn have all been used, but hazel is, I think, preferred, though it is said the virtue does not lie in the wood. I have tried myself with orthodox forked hazel-rods but all to no purpose, while with other people the rod has been most active, turning up at once. Water was certainly found where the prophet indicated, and he also foretold correctly the depth down and the amount. But he could not explain the curious mystery. In one case the diviner claimed that the power had been in his family a long time and descended from father to son. He showed with pride testimonials that he had found water in many different 


\section{Stray Leaves from a Border Garden}

parts of England. He did not seem educated enough to be a fraud. I think the belief in the divining-rod dates back a long time; the Chaldeans are said to have dealt with it, but it has never been satisfactorily explained. Even the wood-wise Evelyn was puzzled by it.

The owls hoot now in the daytime as well as at night, a sign, I believe, they are meditating house-building. I think they are mostly about here Hornie Hoolets, or Long-eared Owls (Asio otus), or Brown Tawny Owls (Strix aluco). White Barn Owls used, I hear, to be common in Berwickshire, but seem to have died out. I heard a delightful ghost story about a white owl the other day.

There was an old house, and a man-servant slept all alone at the top of it. Three nights in succession he saw a white ghostly face at the window, and at last he began to ask himself what sins he had committed. And since he did not remember any sin in particular, "he being a good man," my informant said, he summoned up courage to look closer at his visitor. And lo and behold, a Barn Owl!

I like the Hindoo term for a booby-a Wooden Owl !

February 19.-Picked a little bunch of primroses to-day and some Jasmine. How curious its name in Persian should be Jâsemin and in Arab Ismyn! The French term Jasmin must come from the same.

February 27.-To-day we heard the Wood-pigeon imploring "Do! do! do!" (build) for the first time this Spring. And no wonder, it was such a lovely Spring day! The little Vesper-bells(Scilla) are beginning to show in the garden. How fond bees are of them!- the bed seems alive with them; and the Primroses are multiplying fast in the plantation. The Spurge laurel (Daphne laureola) is beginning to show its graceful tufts of green flowers. It is a pity it is so poisonous, yet it is curious that in very hard winters rabbits seem to eat it with impunity.

March 4.-A lovely sunny morning. What is the old saying about March? "He comes in with a viper's head and goes out with a peafowl's tail," while another version 


\section{The Chrissenmas to Mayday}

is, "March comes in like a lion and goes out like a lamb." "March, the Master of Hounds," Luiders calls him in a pretty little poem I delight in. Boy picked a large bunch of Primroses to-day and some crocuses, "Flower of Love." In the afternoon there were two smart snow-showers and it turned bitterly cold. I came across the following little poem the other day; I think it is rather pretty. I do not know who wrote it. It reminds me of Smetham's youthful efforts :

O little birds that all day long

Carol on every tree,

What is the meaning of your song,

The meaning of your glee?

You are so very, very glad-

How loving God must be!

Dear flowers that blossom round my feet,

It fills my heart to see,

Your smiling faces, when you meet

God's wind upon the lea:

You seem to laugh for happiness

How loving God must be.

And all day long our hearts rejoice, God cares for you and me.

We are but children; yet our voice May praise him merrily,

And we can sing like all the birdsHow loving God must be.

March 6.-Wild scuds of snow and cold, bitterly cold. . . . A weary day to start off wandering. How I pity the poor tramps one sees in the muddy roads as one whisks by warmly ensconced in a snug railway car at the "tail of a lively tea-kettle," as somebody phrases it! They always seem to be burdened with tiny dirty babies and never to reach their destinations.

March 7.-A visit to Teapot Land.

Teapot Land-the words recall a little grey fishing town by the sea, which looked really blue that day, which it does not often, I think, being a cold northern sea, brown- and orange-sailed boats, sturdy blue-clothed fishermen, and the bonniest apple-cheeked bairns tumbling about up and down the outside stone stairs of the dingy mossy houses, and up 


\section{Stray Leaves from a Border Garden}

a rickety wooden stair in a secluded court, Boy and I travelling after Teapots. Yes, there they were in endless array, the dear tiny brown glazed teapots, with bowl and cream jug to match, so ideal for dolls' tea-parties or the elders' early breakfast-tray. Shelves upon shelves of them, it was a veritable nightmare of teapots. A hamperful of charming scarlet hens, purporting to be money-boxes, caught Boy's eye, and a basketful of earthenware apples of most tempting reddish-yellow, likewise penny-savers. There were also endless rows of pale yellow pudding dishes, which, when I admired, I was told were bought by the fisherwives, "the leddies they want white. But the yellow aye last the longest." As we stood in open-mouthed speculation and wondering surprise as to the need for so many teapots, our guide cheerfully added: "We sell a goodish ew in the summer for seaside lodgers and picnic-parties, also to the Dutch merchant-ships." Surely a very quaint cargo. But not so odd as the curly china poodle-dogs of Kirkcaldy over the water, which are taken to Holland by many a Dutch sea-captain as presents from Scotland for their vrows. But I found there was a fashion in curly poodles as in everything else ; the real old variety is hard to get. One is put off with dogs with lockets!

March 2 1.-Easterday in Devon. So bright and sunny, all the hedgerow leaves in the little lane down which we went to church covered with white dust, which even seemed to have alighted on the blackthorn, so white was it with profuse bloom. In the cottage gardens Golden Rush Jonquils coming out, and Primroses.

whe quaintest little brown barn of a church with a thatched roof and tiny wooden belfry, old carved pews decked with moss and bunches of primroses. Two or three real dried palm branches mixed with soft catkins, the English Palm or Gosling, as it is sometimes called, with a few bunches of daffodils, and on the communiontable a tight nosegay of hothouse Calla lilies, evidently the pride of the churchdeckers' hearts. Sunday-clad folks with flowers in their hands coming down the lanes and passing 


\section{The Chrissenmas to Mayday}

the time of day in soft Devon at the door. Within, a veritable Boanerges of an Irish priest preaching with a fervour which should surely land him some day in a bishop's-carved throne.

I cannot forget that little wayside house of prayer among the budding orchards. . .

\section{EASTERTIDE ON THE BORDER}

Down by the water the kingcups are blowing,

On every brae see the primroses glowing,

Soft little pussies on slender saughs showing

In the brown furrows the sower is sowing,

Over the rigs soar the Laverocks sweet singing,

Like a black cloud see the nesting crows winging

To and fro ever their sticks homeward bringing,

Soft in the silence the kirkbells ring, ringing.

Of all sweet flowers the air is sweet smelling,

Springtime is coming, the lambs are all telling,

No longer frostbound the burnies are swelling,

All their brown coats see the chestnut-buds shelling

Now is Earth's Easter, she is now awaking

From her long sleep, she is turning and taking

Unto herself the bright sunrays that, breaking,

Lie on her breast all quivering and shaking.

I left my little Border garden to itself till April I 7 ; when I returned the young lambs were gambolling in the fields and the wild roses snd sweetbriars were in leaf. Primroses, both pink and white and yellow, are now in great profusion, and the hyacinths in the Rose Garden in a few days will be a dream of beauty. But there was wild weather and grim days during my absence, snow and frost. I saw a nest-the first nest of the year to me-a robin's, hid among wood-sorrel leaves- "Hearts" as they call them sometimes here-in a wayside bank in Northumberland, where I was staying, at a charming place where the art of man has coaxed the shy Himalayan primrose to bloom in most artistic and apparently unstudied patches on woodland banks by a lovely brawling brown beck, and where the profusion of many-coloured primroses and daffodils, large and small, is renowned. But I loved the Himalayan primrose best of all with its purple balls of blossom like 


\section{Stray Leaves from a Border Garden}

tiny guelder-roses, and Sikkimensis too, with its pale drooping yellow bells like a cowslip's bells. Art masquerading as Nature has had there a delightful success. I remember yet in my dreams a perfect rivulet of squills blue as the sky which succeeded a shining ocean of golden crocus. I remembered when I awoke these joys were only to be attained by a very open hand in the matter of plant-food. These terraces were irrigated with liquid manure !!!

April 19.-Primrose Day. How curious it is the primroses should now be bound up with Lord Beaconsfield, when I question whether to the great statesman a primrose was really ever anything more than just a primrose by the river's brim! The quiet of our woods is undisturbed by primrose-gatherers, no doubt because all around is thickly sown with Radicals, a weed that springs apace. I am thankful, however, I am encompassed by Radicals, because in England the craze for primroses has ended by almost exterminating the poor primrose in places around London. At one riverside place I know of not a plant can be kept in the shrubbery, but only in the walled garden, a prisoner, but secure. I wonder, by the way, why gardeners are so often Radicals, and even Red Republicans, as was an old Provençal nurseryman of my childish acquaintance, though it always seemed to me somewhat improvident on his part to wish to see all the aristocrats hanging from the lamp-post, since such are generally most appreciative of expensive flowers.

April 21.-A beautiful warm sunny morning, which I spent wandering in the garden counting my treasures. There were several white globe anemones out, rather small perhaps, but we must make allowance for young plants. The Polyanthus, that dear old favourite, "Jack behind the garden gate," as he is called in Suffolk, would have been a brave sight, but, alas, those weary birds will not allow a single bloom to remain in all the border. Gardener complains of the Wild Birds Protection Act as being the despair of gardeners and ruin of gardens. "It was all very I06 


\section{The Chrissenmas to Mayday}

well," said he, "to protect the birds; he was not one to have them exterminated, but he did not see there was any harm in a gardener just taking one or two eggs in any nest he came across, and in those days he had some satisfaction in his borders. It was poor work now!" As I looked at my border with every bloom neatly nipped off and laid beside the bereft parent as if in mockery, I felt inclined to agree when he proceeded to enunciate his idea that gardeners should make laws about gardens and birds rather than folk that have " naething ado wi' them." The pale purple Dog-violets are out now on the woodbanks, and the tiny white Potentilla, St. Hilary's Strawberry, with lots of blue and white Pervinks. A conserve of young Periwinkle tops is said to be good for curing nightmare. The gorse has been out all winter; "when the gorse is out o' bloom kissing's out of fashion." Certainly hereabouts one can always find a sprig of gorse or whin. It is said that whoso brings Whin into the house brings Death. In old days, at Easter, country children used to dye hard-boiled eggs yellow with furze-_ "furres" as it was sometimes delightfully spelt (A. S. Fyrs)-and assemble on Easter Monday to roll them down the steep banks of the River Whitadder. Easter is not kept in the Scotch Church, so these children probably came from the English town of Berwick, but I won't say that many a sturdy little Scot did not join in the revel. Easter Egg rolling is, I believe, still common in America, but seems to have died out in England. The only place where it is practised on a large scale still on Easter Monday is, I have been told, Avenham Park, near Preston, in Lancashire. Onionskin is a capital thing to boil with hard-boiled eggs to make them gold colour. Alum makes a rich purple and cochineal red, and pink if added sparingly to the water. These dyes have the advantage of being quite harmless in case the eggshell should happen to crack. Boy loves the ceremony of Easter Egg boiling, and delights in preparing a basketful of different-coloured eggs for distribution.

Russians are great givers of Easter eggs, I believe, from IO7 


\section{Stray Leaves from a Border Garden}

the Tzar to the moujik. There is a delightful story current about some distinguished personage that he was given an Easter egg from which a mysterious ticking noise was heard proceeding. For fear it should be an anarchist bomb, it was put in a pail of water awhile. It was then cautiously opened, and lo and behold, a harmless and beautiful watch!

Blue grape hyacinths-Jacynths, as my old Queen Anne Herbalist calls them-and squills, yellow wallflower, yellow narcissus and red daisies are all to be found now as well as the French forget-me-not. I also saw a few early lilac violas or tufted pansies, which now, I believe, is the more correct name. But, alas, this afternoon it has turned very cold, and a small steady shower of tiniest snowflakes has begun to fall. A rueful prophecy is being whispered about that we are to have snow all the summer. Alas! alas! how about the budding hyacinths and coyly opening tulips ! Certainly the one charm said to be eternal, that of "the unexpected for ever befalling," is never absent from a garden. There is a legend that when a maiden finds a sixpetalled primrose she will see her lover. I found one the other day, also an eight-petalled one, but they are not so pretty as the common kind, I think, though curious.

\section{THE SIX-PETALLED PRIMROSE}

Granny sat spinning by her fireside,

Birr, birr, birr.

Her bonny brown hair young Lilias tied At the glass, with a little dimpling smile Flitting over her face the while.

"Where are you going now, Lilias dear ?" Birr, birr, birr.

The cracked voice whispers, the dim eyes peer.

"Down in the dell where the primroses dwell, Down by the fell, by the Fairies' well."

Granny looked gravely up from her wheel, Birr, birr, birr.

Lilias stept softly, she wished to steal Thro' the open door and get far away Before old Granny could bid her stay. I08 


\section{The Chrissenmas to Mayday}

Fortune was friendly, she snapt a threadBirr, birr, birr-

Poor Granny's misfortune and her dread.

Lilias was over the fields and gone

To the Fairies' Well, so deep and lone.

The "simmer" clocks they filled the air, Birr, birr, birr.

In clouds here, there and everywhere.

Lilias cast herself down and sadly cried:

"O that my love were by my side."

The water drops in the Fairies' Well, Birr, birr, birr.

Countless her teardrops as fast they fell, 'Mid the primrose stars like diamonds shone,

Glittering upon each mossy stone,

Whispered the aspen leaves o'er her head-

Birr, birr, birr-

"Dost not remember, old Granny said,

If a six-leaved primrose a maid doth find

Cometh a lover upon the wind."

The rustle died in the aspen leaves, Birr, birr, birr.

At last the seeking Lilias perceives The magic flower she longs to find. Afar in the valley uprose the wind,

In her slim fingers she turned the flowerBirr, birr, birr-

The wind grew higher, within the hour Round the rock came a little sailor lad, Lilias met him with eyes grown glad.

Granny sang at home to her busy wheel, Birr, birr, birr.

The couple a march upon her steal,

"Here's Jamie, Granny, come home from sea,

The six-leaved primrose brought him to me."

April 22.-A beautiful sunny morning. Boy and I gathered quite a big bunch of white violets from under the apple-tree in the kitchen-garden, also some lovely purple auricula. Boy says he thinks it must be called "Bear's Ear," because the leaves are the shape of a bear's ear. $\mathrm{He}$ has such a large acquaintance with bears, no doubt he knows! But is the calm assurance of children's 


\section{Stray Leaves from a Border Garden}

assertion so very different to that of philosophers of later years? Are we not always being solemnly assured the moon is indeed made of green cheese, and as solemnly our grand.children are told (and some of us live to hear it) that indeed and indeed 'tis but sweet whey consolidated ? We waged war energetically this morning against the pig-weed's feathery green sprays. Bishop-weed our Presbyterian gardener calls it. An old name for it was Herb Gerard and Gout-wort, from the high opinion old "poticaries" had of its medicinal virtues.

April 25.-A pouring wet day. I begin to wonder when the earth will dry, it has been so wet lately. Boy's birthday. He had planned picking primroses with some little friends, and had even dreamt of picnicking in the "plantin." But, alas! April in the North is scarcely a month for picnics.

April 26.--A lovely summer's day; why did it not come yesterday? I picked primroses nearly all day, and grudged coming indoors even to eat. How convenient it would be sometimes to be like a Boa-constrictor, able to take a meal to last for a Week!

April 29.-Rain again. We planted some seedlings of white Spanish Broom - "Portugal Broom " some people call it-and hope they will take. I have a dim recollection of seeing as a child lovely bushes of this broom in the neighbourhood of Bayonne. I think it must like rather sandy soil. The Osmunda Regalis fern, too, grows profusely near there in the ditches on either side of the way leading to the English Soldiers' Cemetery. Such a pretty, quaint little spot! I remember it still.

\section{THE GUARDS' CEMETERY AT BAYONNE}

Beyond the town a sign-post bids you turn

Off the highway, along a country lane,

Shadowed by trees, and high banks fair with fern.

Under the shadow of the wood they rest,

No whispers waken and no cannon rouse

These-folded to Earth Mother's quiet breast.

"Killed in the sortie, buried where they fell,

After the furious fighting at day dawn."

Thus to all time these few grey tablets tell. 


\section{The Chrissenmas to Mayday}

Beside them, pointing upward to the skies, And evergreen, to mark their names should live,

Tall cypress stand, as silent sentries rise,

And, for a brother's sake who shared this lot,

A woman's tender hand was found at last

To rail around and mark with stone the spot, And tho' the dust of rank and file could not

Be gathered in from all the slopes around,

Where'er they fell-yet they were not forgot.

Amid the rest a "Sixtieth Rifle" lay,

Buried among the Guards by some kind hand ;

$\mathrm{He}$ too had fallen on that fated day.

And-in a corner, stands a little stone,

In memory of a Colour-Sergeant, placed

By some one of his comrades, now unknown!

His name and corps, and then "Adue, my friend,"

Thus quaintly spelt, in black old letters carved,

And faltering somewhat, near the bitter end,

A few steps further, on the moorland slope,

Three of the gallant Scots Guards fell on sleep :

Left in an alien land, to rest in hope,

Until a louder trumpet call shall sound

Than that which woke them from their well-earned rest,

To a death-struggle o'er each inch of ground,

Here and below by yonder chain of lakes,

Weedy and willow-grown and wet and wild :

Give one poor thought to all their gallant sakes,

They whom these loved are dead or waxen old.

The echo of their deeds grown faint and far,

For these all love and sorrow hath grown cold.

$\mathrm{Oh}$ ! while ye honour soldiers of to-day

Forget not quite these soldiers passed away.

Waiting the trumpet call!

Sleep, silent soldiers, sleep!

Rest ye in Hope until a fairer morn

Than brought you Death shall surely dawn.

April 30.-Grand fishing weather. Nearly every one of these wet days some trout has been caught in the little river; lovely little spotted trout, which remind me of speckled beauties in the Italian mountain streams. How I should like to be like Thoreau, who is said to have had only to put his hand into the water to be able to bring out a fish lying cosily, and quite undismayed, in the palm of it! The rain turned to snow this afternoon; but, luckily, did not last long, nor did it lie. But the rain has beaten down some of my lovely hyacinths ; happily the tulip-bed of mixed beauties does not 


\section{Stray Leaves from a Border Garden}

look a whit the worse. The Tulip has been said to be a flower without a soul ; but of the small size, pale pink and yellow ones, I think this is scarcely true, though the Giant Greigi and others are rather coarse-looking and soulless, perhaps. The birds are beginning to nest. There is a blackbird's nest in a laurel-bush. Merle they call him here, and Garden Ousel. The Welsh namefor a blackbird is rather nice -Goldbeak (Pig felyn). I am sure there is a starling's nest in the ivy just above my bedroom window. A starling preens his speckled beauty daily on the little balcony; indeed, one day, when the window was very wide open, he investigated the bedroom. I wonder what he thought of it! I was interested the other day to learn that starlings are largely exported to America as cage-birds; I suppose, on account of their talking capabilities. 


\section{CHAPTER VI}

"ALL IN YE MERRIE MONTH OF MAY"

A merry time it is in May,
When springeth the summer's day,
And damisels carols leadeth
On greenwood fowls gredeth.

Romance of Merlin.

May 1._-"The rain it raineth every day." Such a Mayday, everything dripping, and so cold! The morning opened with a snow shower, which ended in rain which never ceased falling all day. There is a Scottish tradition fairies may be seen of mortals on May-day. I hardly think the "Good Neighbours" will be abroad to-day, though this morning I did see a good many Pixy-stools, as the Devon folk call toadstools or fungi. Fairy-tables, the Welsh call them : a name which Boy also gives them. Here they are called Paddock or Padick-stools and Paddystools; Paddock or puddock meaning a toad or frog, probably from the Icelandic podda. I remember being told of a person who was much worried by many worries: "He's as comfortable as a puddock under a harrow." Herrick, many of whose words I have recognised hereabouts, has a charming little "Grace before Meat" for a child, as follows :

\footnotetext{
Here a little child I stand

Heaving up my either hand,

Cold as paddocks though they be,

Here I lift them up to thee,

For a benison to fall

On our meat and on us all! Amen.
}

Boy asked why Toadstools had that name. "Do toads sit 


\section{Stray Leaves from a Border Garden}

on them? Did you ever see one sitting on a toadstool ?" He was much disconcerted when I said I never had, and declared he would watch carefully for the sight. When I told him they used to be called also sometimes "Todes-hattes," the big ones do for stools and the little ones for hats, he decided. Americans call them Frogstools. Spenser talks of the "grieslie Todestoole and loathèd Paddocks lording on the same." In Roumania toads are called " witches' servants." In folklore, though toads are of evil repute generally, yet they sometimes bring luck. In Tuscany it is unlucky to kill a toad; it may be an enchanted prince or princess. An old Scots term for a fat little child used to be " a fat Podle," which was also used for a tadpole. There is a delightful Indian proverb which says, "A tadpole caught by one's own child is deemed a fine fish." Grimm has an amusing folk-tale about an old fat frog who befriended a younger son on his travels, and when she heard he was in search of a beautiful princess to take home, gave him a small frog. I told Boy how the toad was said to carry a precious jewel in his head, called a Toadstone or Bufonite, and he was much interested and all agog to find a toad. But they are not very common here, though I did see one the other day in the Rose-garden. A Toadstone used to be thought a preservative against poison, and was set in jewellery; it was generally yellow and green in colour or sometimes black. It was worn sometimes set in rings. Erasmus mentions a Bufonite dedicated to Our Lady of Walsingham. It has now, I believe, been discovered that Toadstones are the fossil teeth of some antediluvian fish. Paddockstanes was the old name. Toads are said to make interesting pets. The legend that they are venomous has probably arisen from the fact they exude a sort of irritating liquid if touched. Dogs are said to get swelled mouths if they seize toads. I knew a lady who had a toad as a pet, and used to keep it in her room and let it hop about on the table and eat out of her hand. Boy found some dear little grey Pezizas in a niche among some fallen branches; he calls them fairy Tam O'Shanters. In 


\section{"All in ye Merrie Month of May"}

Wales the Peziza coccinea is called "Fairy Hat." The fairies are associated with so many things! In the waters of the River Teviot odd little stones are sometimes found, called "fairy stones," which are said to bring luck to the finder. Wise men, however, declare these are concretions of a fossil worm covered with sand. Such, I believe, was the opinion of the late Mr. Milne-Home, Fellow of the Scottish Geological Society. Small stone hatchets, sometimes found in Scotland, go by the name of "Fairy Hammers"; while "fairy greens" or "fairy rings" have long been deemed the spots whereon the fairies dance at night. Fairy hillocks, some people say, conceal their dwellings.

A sort of fungus (Tremella arborea) found on the roots of old trees is in some places called "Fairy Butter," because after rain it looks rather like butter, and the fairies are supposed to make it in the night. The following is an old recipe for "Fairy Butter." As it is well known that fairy gifts, if the recipient betray their origin, promptly disappear, I may not further divulge whence my recipe came, except that it was found by me in a turretroom full of lumber, in the old Castle, the home of our clan. "Here be," as Boy used to say: "Take the Yolks of four Hard Eggs and half a Pound of Loaf-sugar, beat and sifted, half a Pound of fresh Butter. Bray them in a clean Bowl with two Spoonfuls of Orangeflower Water; when it is well mixed, force it through a Corner of a thin canvas Strainer in little Heaps on a Plate. It is a very pretty Supper dish." I wonder it is not among the menu of the feast set before the King of the Fairies as described by Herrick. There is a Border superstition that the fairies flit whenever the plough and harrow turn up their country haunts :

Where the scythe cuts and the sock rives

Hae done wi' fairies and beebykes.

And no wonder; the long straight "rig and fur" is not as pretty as the grassy field with their beloved thyme and harebells and Peeseweep grass (Luzula campestris) and 


\section{Stray Leaves from a Border Garden}

one can well imagine the Queen of Elfland and her maidens not caring to tarry among the upturned stones and heavy earth-clods, but clad in their gowns dyed elfin grey, as tradition declares, with lichen, or green as grass, mounting their faery steeds, which to dull earthly eyes, untouched by fernseed, are but branches of broom or ragwort, and away, shrilly piping on their hemlock and oaten pipes, to the

Land of love and land of lychte

Withouten sonne or mone or nychte;

through the rivers of red blood which bar the way to bonnie Elfland, since, as Thomas the Rhymer tells us,

$\mathrm{A}^{\prime}$ the blude that's shed on earth,

Rins thro' the springs o' that countrie.

Dark was the malison which protected the lands the fairies loved. There was an old rhyme, once well known, which warned any would-be upsetting churl that

He who tills the fairies' green,

Nae luck again shall hae,

And he who spoils the fairies' ring

Betide him want and woe :

For weirdless days and weary nights

Are his till his dying day.

This and many other curious and popular Border rhymes, sayings and proverbs, have been saved from oblivion by Dr. Henderson, whose interesting little book is now, I am sorry to say, out of print. In a bundle of quaint rhymes by the Ettrick Shepherd, known as "A Queer Book," the origin of the Border fairies is given, a tale of glamour and mystery, describing the elves in the gold and green, who frolic in the moonbeams or on the bridge of the rainbow, and haunt the woodland bowers, and live in the heart of the wayside rose.

In olden days Brownies or House Elves are said to have haunted the Borderland, for there is an old saying, when a child gets something good to eat, "Here's a piece wad please a Brownie!" Scones and heather honey were 


\section{"All in ye Merrie Month of May"}

said to be the Brownies' favourite food, and bowls of cream.

It was said that Heaven had ordained Brownies to help man after the Fall, so they were forbidden to take any guerdon except food, which had to be set out overnight on the hearth. Report declared they were like tiny little mortals, but naked. And there is a story that some kindly soul once laid out for the Brownie of the house, along with the customary cream and cakes, a little suit of clothes, and heard in the night Brownie departing, singing:

A new mantle and a new hood, Brownie, Brownie, ye'll do nae mair guid.

Brownies are sometimes identified with the Swartalfar or swarthy elves of the Edda, as the Liosalfar or fair white Elves are with Fairies.

There is a delightful Danish belief that if you hide under an elder-tree at midnight on Midsummer Eve you will see the King of the Fairies ride by with a sparkling train. But, alas! all these quaint old-time fancies are wilting before the fierce light of civilization, as the fairy steeds of old time turned to leaves at the sign of the Cross, and all inquiries about any bit of folklore are apt to be met with a dignified disclaimer of interest therein; such as I well remember meeting with when I tried to elicit sundry West Indian folk-tales from ancient negroes: "Dat foolishness; wonder missus car to har dat!" Romance seems, however, to have been better treated in olden days, since it is on record that in the reign of King James IV. (I 488-1 513 ) money was paid to one "Widderspune that tauld tailis to the King," evidently a sort of Scottish Troubadour. Rain again to-day! It is Christina Rossetti, I think, who sings the praise of winter rain.

Selkirk, a too little known Border poet (Poems of J. B. Selkirk, published by Blackwood), calls the spring rain

The baby drink of the firstborn flowers.

Yet surely it is only after living awhile on the edge of the 


\section{Stray Leaves from a Border Garden}

Sahara or on the African veldt one would appreciate rain properly. I can never give an enthusiastic welcome to rain when I see my beloved roses hanging heavy heads and scattering sweet petals on the sodden earth, and the river coming "down" in swollen sulky brown spate, and a steady downpour of rain prevents one going out.

Yet, I suppose,

Were all the year one constant sunshine wee Should have no flowres ;

All would be drought and leanness, not a tree Would make us bowres.

Henry Vaughan.

George Herbert's Proverb is rather nice :

Although it rain, cast not away thy watering-pot.

In India, I suppose, one would welcome Mme. la Pluie with open arms, at least in some parts of it. Mark Thornhill, in his interesting book of Indian Mutiny experiences, describes beautifully the coming of the rain in India. . . . "The sky was thick with dust and the air motionless, hot, and stifling as that of the Black Hole. Looking towards the horizon, it seemed to us as if the bank of dust were becoming thicker and that real clouds were mingled with it. As we gazed there came a movement in the atmosphere, and presently a gentle wind began to blow cool and fresh, as if it had come through water. As the wind blew, the bank of dust advanced towards us, it rose and spread, in a few minutes the heavens were concealed in a canopy of rolling clouds. Presently there came a flash of lightning, a crash of thunder, and then the floodgates of the heavens were opened and the rain descended-at first in heavy single drops, then in streams. For two hours it continued to pour. When it ceased the face of Nature was changed. The dust had gone, the clouds had vanished, we gazed on a sky of azure brightness . . . as the rains fell a delicious coolness pervaded the air; it woke ... all Nature to life and enjoyment." 


\section{"All in ye Merrie Month of May"}

\section{THE ANGEL OF THE RAIN !}

Who comes? With a sound of rushing wings,

Of waterspouts across the arid plain,

Of waterfalls and wakening springs,

The Angel of the Rain!

With silver feet across the darkening sky,

And all the clouds of heaven in his train,

Girt with the Rainbow-veiled to mortal eye,

The Angel of the Rain!

A Breath unto the thirsty ground,

Afar, abroad, earth growing pure again,

Obeying stormwinds circling him around,

The Angel of the Rain!

May 2.- The rain has brought out all the wonderful pervading scent of the sweetbriar bushes just beginning to be in leaf; it is delicious to walk in the lane to-day. Sweetbriar Lane is said to be haunted. Down in the hollow by the tall firs, where there used to be a ford, but where now the burn is bridged, I am told a phantom dog wanders. Did he lose a beloved master there in some winter spate? I do not know, and I cannot even find out what manner of a Doghe was, but I should fancy a Collie with fluffy feathery tail and clever canny face, like old Toss at the farmsteading; collies are so 'cute and attached to their masters. They are very difficult to get, as shepherds never like to sell collie pups for pets, but only for shepherds' work. In the Highlands they go to church with their masters, but apparently that is not the custom here. Toss is not a dog who gives his friendship to all comers, or indeed quickly to any; he is a true canny Scot. We hunted in the beech hedge to-day for nests ; it was still brown with its winter's leaves. We only found last year's empty bird-homes, some so ramshackle and tumble-to-pieces, just like cheap unlet tenement houses. The squirrels are very busy in the "plantin" ripping off the chestnut-buds. They are so tame they will sit still in the grass as we pass, or scurry a few feet up the bole of a beech, and peep at us round the 


\section{Stray Leaves from a Border Garden}

trunk, making a curious gobbling noise, no doubt scolding us. Some people abuse squirrels as mischievous, alleging they eat birds' eggs and are very destructive to trees and shrubs, but I should be very sorry to be without them. But they never let us get very close to them, tame as they are. Thoreau had such an attraction for wild squirrels, and indeed for all wild animals, that I have heard the squirrels used to come and nestle to him. He is said to have been the original of Hawthorne's Donatello. Thoreau's knowledge of Nature was such that R. L. Stevenson says he could have told the time of year within a day or two by the look of the plants.

There is an old saying you should think twice before you introduce one friend to another; surely you should think twice before introducing a new animal or plant to another country. Squirrels, once unknown here, now overrun the Border, and Scotch settlers, it is said, introduced their beloved Thistle into Tasmania, and have been only sorry once. Likewise with those who made the Rabbit acquainted with Australia, and the Indian Mongoose a denizen of Jamaica. As to the Hanoverian Rat, he has long been the curse of Britain. I remember, too, it has been said that the dwellers on the banks of the River Exe suffer in summer time from Mosquitoes introduced unbeknownst by Spanish onion-ships which came a-trading to the little Devon seaport of Topsham, once, by the way, a rival port to London! sending a greater number of ships to combat the Armada. I will not vouch for the mosquitoes, I have not seen them, but I have seen picturesque black-eyed lads ashore from the onion-ships with strings of big Spanish onions for sale!

It is curious to think that some of our long-established plants have first, it is said, been found on ballast-hills, having come amongst the stones and rubbish brought from outland ports by ships unfreighted. One alien seems so far to be a success; the little creeping yellow Broom from the Highlands of Auvergne, trained up a wall here, has taken kindly to its new home in the Scotch kailyard and has burst out into a mass of golden bloom; the French 


\section{"All in ye Merrie Month of May"}

sorrel, too, has done well. It is not, however, a foreign vegetable likely to become very popular; I fancy not like the tomato or love apple or gold apple which has had the most extraordinary popularity in a comparatively short space of time with all classes of English and Scotch. The Cowslips, Paigles, as they used to be called long ago, a name which still survives in East Anglia, (and there also means a "spangle,") are out now, but do not seem to be doing very well yet in my garden. There is an old Scotch word, a verb, to be "paigled," meaning "to be drooping with fatigue," from the Icelandic piackur, drooping. I wonder if the Cowslips gained this name from their habit of drooping their heads? Primel or Coucou is their French name, perhaps because they come with the Cuckoo. They, too, are colonists in a small way here, from Weymouth, where the fields are full of them. They occur but infrequently about here. Boy can never know the pleasure of a Cowslip Ball.

I always wondered what the name Cowslip, pronounced here Cooslip, came from, and I heard the other day it was a survival of the Anglo Saxon Cuslyppe. Doctors seem to differ very much as to the meaning and derivation of it. Cockayne says Cu-cow and slyppe-lip. Ben Jonson talks of Dayseyes and the Lips of Cows. Prior goes off to the Flemish Kouss-hose and Lopp-flap, and thinks it reached the Cowslip by a confusion with the Mullein, also a Verbascum. An old name for breeches was "slops," and to me there seems no difficulty in thinking the flower got its name from its similarity to the full hose or slops of the olden days. Not a very romantic derivation, but I think old-time folk were more practical and coarse than sentimental and daintyfancied. Cowslip wine used to be made in the Borderland, but it seems a lost art now. I believe that Cowslip tart used to be a favourite dish with our forebears. I wish I had the recipe for it, though, indeed, I do not know where I would find enough of flowers to try it, as they do not seem a common flower in this neighbourhood; though a few miles from here I know a field where they grow, and also 


\section{Stray Leaves from a Border Garden}

on the seaside heights near St. Abb's Head. Although they are generally deemed a flower peculiar to pastures, I remember seeing them under trees on a hillside of the Riviera; it seemed as though they had found the heat of the open field rather much and had run into the woods of the old Carthusian monastery for shelter.

Boy is asking every one a funny riddle just now : "Why is it dangerous to go for a walk in Spring? Because the bull rushes out and the cow slips about!" I recollect a dear old garden where they grew in lovely selfsown clumps under the old gnarled grey apple-trees, their Fairy Favours very apparent. Boy loves the Fairy's Song out of the Midsummer's Night's Dream ":

Over hill, over dale, Through bush, through brier, Over park, over pale, Through flood, through fire, I do wander every where, Swifter than the moon's sphere ; And I serve the Fairy queen, To dew her orbs upon the green. The cowslips tall her Pensioners be : In their gold coats spots you see; Those be rubies, fairy favours, In those freckles live their savours : I must go seek some dewdrops here And hang a pearl in every cowslip's ear.

"I remember, I remember, an old garden fair and sweet." These words come to my memory whenever I think of that garden. It was on a sunny slope, and on three sides stretched moss-grown, old red-brick walls, up which crept aged pear- and plum-trees, which in their season were literally bouquets of bloom. It was divided down the middle by a grass walk, with a low holly hedge on either side, which ended in a round stone bason with purple Flower de Luce, where in old days there had been a fountain and shining water. Now it was dry. Along the bottom by this bason ran another grass walk, bordered by "Snow in Summer" and "None so Pretty"; and beyond the low wall, thick with lichens and oak ferns, was the delightsome old grey 


\section{"All in ye Merrie Month of May"}

orchard full of Giant Cowslips, yellow and tan-coloured; and in one corner, under the ivied wall, nestled a clump of Rhubarb, with its beautiful red stalks and mighty green leaves. People talk of Acanthus. It is beautiful, but I think the Rhubarb quite as beautiful, and I always have a fellow-feeling for the old Scots cobbler who put it as an ornamental plant in the forefront of his wayside garden. The old monks were very fond of copying natural leaves and flowers in the carving they put in churches, and in some cases, notably at Melrose Abbey, were very successful. There is a pillar in the south transept where the carving is particularly fine, representing the curly greens or Kale to be seen to this day in every Scotch garden or kailyard. This word Kaleyard is derived from the Danish kaal, cabbage, and gaard, garden or yard, pronounced yaird. They also excelled in cooking, it would seem, since the old song says they

Made guid kail

On Fridays when they fasted,

Nor wanted either beef or ale

As long as their neighbour's lasted.

There is a cloister, too, at Melrose, beautifully carved with a variety of flowers-Lilies, Roses, Heath, Ferns, Oakleaves and Thistles.

A beautiful modern example of this nature-carving may be seen at Wellington College Chapel, where there are carvings of Fir-cones, Polypodium, Foxgloves, Heath, Waterlily, and Osmunda Fern ; and in the ante-chapel such plants represented as are to be found in wild and desert places beyond the pale of the Church-Thorns, Brambles, Figs, and Apples, emblems of the Fall. In the apse every capital has special reference to the window. For instance, the Ascension window has evergreens and the Baptismal one, a water-lily. Thanks are due for all this to the taste of Archbishop Benson, who was headmaster at the time. Certainly thistles are very ornamental. A small railway station near here often has its strip of garden along the back of the platform full of Giant Thistles, planted in a double row like 


\section{Stray Leaves from a Border Garden}

Soldiers; truly a grim phalanx few would have cared to face. I think they were of the kind in the old Herbal called Thistle Melancholy, from an old belief it drove away melancholy, if, according to Dioscorides, that delightful old ancient,

The root was borne about one.

Another kind was "Thistle Hartichoaklike," which certainly resembles! an artichoke in the matter of its leaves, and is a handsome ornament to a waste corner. Thistles are called Thrissells here. This is a very old name, as it is mentioned in Dunbar's poem, "The Thrissell and the Rois," on the marriage of James IV., I503. They were formerly used as food for cattle ; "cattel," as my old Herbalist spells it, and, in consequence, no tarmer waged war against thistles, but rather they were considered a crop. In the archives of the Priory of Lindisfarne, or Holy Island, r 344I 345 , there is a note of thick leather gloves required for the gatherers of this crop! I have heard gloves of this kind were manufactured within the last hundred years-I do not quite dare write "century." The round cakes of shortbread, which appear in Scotch baker-shops at New Year time, have often thistles in pink and white sugar on them, and the motto, "For Auld Lang Syne." They have certainly not ceased to be the national emblem, though it is curious that Scotchmen never seem able to tell one for sure which kind of thistle is the national emblem. But a thistle which resembles Our Lady's Thistle (Carduns Marianus) is figured on the money coined by James $V$., who was the first king to put thistleheads on the Scotch coinage. In old curiosityshops I have sometimes found cut-glass wine-glasses and decanters cunningly engraved with thistles, or even fashioned in the shape of thistleheads, and the horn spoons sold in Edinburgh have often the dearest little silver thistles on the end of the pointed handle. In the Inventory of King James III.'s jewels there are some ornaments fashioned as thistles. The insignia of the most ancient and noble Order of the Thistle are very pretty; the Star especially, 


\section{"All in ye Merrie Month of May"}

with its thistle of green on field of gold. But $I$ have strayed far afield from the old garden; there were no thistles there. I suppose the flowers had once been in prim single tufts in these borders, but when I knew them the rich red, purple and white Globe Anemones were encroaching on the pink Dogtooth Violets and elbowing the Crocus and Double Primroses, while the bright little Grape Jacinths had spread till it seemed a patch of blue sky had come down from earth. Then there were clumps of literally giant Cowslips and Polyanthus among the parsley, and dear "Dusty Millers." There were Violets, too, under the wall, the "Choice Flower of Delight"; and Double Wood Anemones, Windflowers or Flawflowers, from the idea that even a flaw of wind moved them; and patches of Alyssum and bee-haunted Scillas, white Honeyflower, lying in pink tufts along the border ; and last, but not least, the dear little old-fashioned Canadian Puccoon or Bloodwort, looking like a tiny white Waterlily strayed from the water. The paths were all inlaid, in a curious fashion, in a mosaic of stones. How painstaking must have been the gardener who worked out that intricate pattern, or how fanciful the master! "And how cheap labour was in those days compared to now!" remarked a prosaic soul to whom I made the above comment on my paradise. I had a vision of the master, a grey recluse loving his garden; like Dionysius, more interested in the fate of his cabbages than the welfare of the empire; and I felt the man who rides a hobby should be envied of those fellow-creatures who have none, since for him the sometime dull web of life is shot with iridescent threads-iridescent to him though invisible, in some lights, to others. 'Then I heard of a gay family of daughters who had played about that garden long ago, and gathered primroses and daffodils in the surrounding neighbourhood, and lived in the old tumble-down mansion-house with its ivied turrets; and, as I gazed down the beech avenue into the blue distance, I became aware of a tall grey woman disappearing through the old blue door into the garden. And I remembered how I had heard tell of one sister of all the merry band, yet 


\section{Stray Leaves from a Border Garden}

surviving, who was wont to come and wander, a ghost before her time, in the haunts where she had been happy. The place was very lonely. No one ever seemed to come or go but an ancient gardener in charge, who kept the walled garden in a sort of order. Outside, however, he made no sort of attempt to stem the tide of neglect. The dead branches lay wherever winter's winds had dropped them, and the birds, unmolested, literally swarmed. It was a paradise of birds-Birdland indeed. In the spring the bird concerts were surprising, and every corner hid a nest. The starlings crowded the ivy on the old house, and even flew inside through the broken windows. Within all was desolation. Faded curtains and hangings, the once brightly polished tables and chairs dull and dirty, an occasional lovely china bowl or plate, recalled that the place had once been inhabited by people of taste; and an old spinet, with notes long dumb, testified to some one having loved music. In the bedrooms were quaint old worm-eaten, cobwebby fourposters, the stairs creaked ominously when one ascended them, the pretty old oval mirrors reflected one's face so altered, one might almost fancy one beheld the face of some long-departed owner of the old home. There had been children there long ago-a tall old-fashioned fender bore witness to that-and a little quaint pair of tiny black wooden elephants looked curiously out of place in that unmistakable English home. I wondered if they had been brought from the far mysterious East by the officer whose black silhouette still hung in one of the bedrooms, and given perchance to the little lady whose small faded white satin dancing-shoe lay on a table by a bowl of potpourri whose scent had long since departed! Speculation, all idle speculation; no one to tell, no one who knew; no one left who cared.

The heir was an officer in India, a Bengal Lancer, who probably had never set eyes on his inheritance, such as it was, and the only visitors the old place ever had was that lonely woman and my unnoted self. But I was only a bird of passage, a summer swallow who departed, and the old 


\section{"All in ye Merrie Month of May"}

garden knew me no more. Is it still there, I wonder, in its quiet stillness, with its long avenue scented with white thorn and eglantine, at the end of which was a little slated gardener's cot under a spreading sycamore-tree, where on the doorstep played a tiny blue-capped imp who knew no world beyond that iron garden gate, and whose highest dream of bliss was a very occasional visit with grandad to the "big hooss"? I doubt it; little imps grow big and the Board school will have engulfed that tiny one and planted seeds of knowledge. He will have learnt to rob the birds'nests in spite of Government protection, and the hand of the modern "improver" will have come down on the oldfashioned house and improved it-save the mark!- off the face of the earth. One should never revisit a beloved haunt, but rather keep it enshrined in one's memory. The gardens of memory they never fade . . . . (Note.-I have been back and found it cleaned up! restored! The old gardener and little imp gone; the hand of the "improver" has been heavy upon it ; its charm has flown.)

May 3.-My Checkerlily-Fritillary some people call itis out to-day. Checked Daffodil White of Selborne calls it. How pretty it is! I must try and get the white and yellow Armenian forms. The yellow Goosebill Tulips, too, are out. These last came from Devon, from an old friend's garden where they grew in lovely abundance, mixed up with yellow Crown Imperials and purple Satinflower or Bulbonack. My friend first found them in a cottage garden, and was told by the old cottage dame they were called Goosebills because "why they arched their necks same as the geese out yonder." They are most graceful, and, when once established, prolific; when overblown they look like golden stars, and remind me of the little wild yellow tulip of the Riviera, which has been almost exterminated by the plantgrubber. Loudon writes: "One of the most beautiful tulips is the wild French tulip Sylvestris, which is most elegantly striped of a beautiful yellow and fragrant white ; is occasionally found wild in England." I have heard of it being seen wild in Northumberland, also in a plantation 


\section{Stray Leaves from a Border Garden}

some miles from here. I fancy it must be the same with the Italian tulips described, but not pictured, in my old Queen Anne Herbal. In both France and England it is evidently the wild form of tulip. Our Garden Tulips are said to have come originally from Turkey and Dalmatia, and their name Tulip is from Tulipan, Thoulyban, Turban or Turkscap, whence they were formerly known as Turkscaps or Dalmatians. Old Thomas Fuller calls "the Toolip a well complexioned stink, an illfavour wrapt up in pleasant colours," wherein I think he is sometimes hard upon the "Painted Lady" of the parterre, since it cannot be expected all flowers should be blessed with a sweet scent any more than all women with beauty. An odd old name for the tulip was Satyrion.

May 7.-I spent the afternoon howking at the Bishopweed in the Rose-garden borders. Verily one would need the cast-iron back with hinges, of which discourseth pleasantly good Master Warner in his book, "A Summer in a Garden," to do real good work against this inveterate nuisance. It does seem very difficult to know of what good are weeds. Wordsworth calls them "flowers out of place." Malerba, or bad root, the Italians call them so graphically. Certainly they seem gifted with a most marvellous power of reproduction, and to have more lives than the proverbial cat. It has been said in America of that most troublesome "planten" (Plantago Major), or wabret, that it always springs up wherever the white man penetrates. The Indians call it White Man's Foot, and in Hiawatha, Longfellow sings :

\section{Wheresoe'er they tread beneath them \\ Springs a flower unknown among us, \\ Springs the "Whiteman's foot in blossom."}

The worst of grubbing up the wabret is that it leaves such pits in the grass, and I have not sufficient faith that it will not resurrect, to follow the old receipt, and bury it upsidedown in the hole. Boy brings great energy to weeding, camps solemnly in the Rose-garden on his housemaid's mat, provides himself with a grype, better known, perhaps, 128 


\section{"All in ye Merrie Month of May"}

as a three-pronged fork, and then carefully devotes his attention to old Grundyswallow, Chickenwort and such small deer, leaving me the tall Sowthistles and the indomitable Bishopweed. I think Sowthistles are particularly troublesome from a little playful way they have of breaking off sharp in one's hand, leaving the root hard and fast in the ground, which, I think, goes down to the Antipodes. There is an old belief that, if properly invoked, they will lay bare hidden treasures. But the secret seems to be lost in these prosaic days. They are called Swine Thrissells here, and an old name for them was Hare's Palace (French, Palais de Lièvre; Ger. Hasenhaǔs) and Hare's Lettice, from a fancy, chronicled by some bygone herbalist, "that if the hare come under it he is sure no beast can harm hym." In Topsell's veracious Natural History, it is alleged that the Sowthistle is a cure for every disease a hare is liable to; while Askham says, "Yf a hare eate of this herb in somer when he is mad he shal be hole." Now there would seem to be no beast so melancholy as the hare according to ancient sagacity. Water distilled from Sowthistles is an old cosmetic said to be good for the complexion, and the young tops in spring have been recommended as a dainty dish. I confess I have never yet tried this. There is further a pretty persuasion that Sowthistles were among the grass and herbs gathered for the Virgin's bedding in the manger, whence it comes that they are sometimes used to deck the crêches in Italy along with holly and moss. Chickweed or Chickenwort follows in the track of the white colonist, and in New Zealand the Maoris call it the "Mark of the Paleface." It has long been in repute as a barometer, for if fine weather is coming it opens, but if it closes, rain is in the air. It also has medicinal virtues. Here is a receipt, from my Queen Anne Herbal, of compound oil of chickweed, which should be most useful after a prolonged tussle with obstinate weeds: "Take Green Chickweed, fresh Red Rose leaves, of each 2 handfuls; Oil of Trotters 2 pounds. Boil till they are crisp and strain out. Repeat this boiling with fresh Chickweed, and red 


\section{Stray Leaves from a Border Garden}

rose leaves, twice, strain out and keep it for use. Being anointed warm and well rubbed in upon sinews which are strained it is a most Excellent Thing. Let it be used morning and evening, and in a little time the Patient will be cured." Centonchio is the Italian name and Hühnerdarm the German. Groundsel, called hereabouts sometimes Grundyswallow, a corruption of the old Anglo-Saxon groundswelge, "ground eater," was supposed to be a good cure for ague, and "a groundsel poultice sovrain for sprains, likewise for Jaundice" ; and in my old Herbal I find the following: "Pliny has a Relation for the Cure of Toothache which though it seems fabulous we shall here relate. You must dig up the Plant without any Iron Tool, and then touch the acking Tooth therewith 5 times, spitting 3 times. After every such Touch, which done Plant or Set the Herb again in the same Place so that it may grow, and the Toothach shall presently cease and be perfectly cured." Delightfully easy recipe to follow! A Chinese cure for toothache is to lance the gums in order that the tiny worms which are said to cause the pain may be extracted. In this connection it is strange that an old Scotch term for toothache used to be "the worm," because it was said the gnawing of a little worm caused the pain. Newly plucked groundsel laid to the smart left by the sting of a bee is said to cure it at once. Groundsel is one of the plants cited as forming the Virgin's bed along with thyme and woodroof and sowthistles. Here is a quaint old local rhyme:

$$
\begin{aligned}
& \text { Storm and wind, } \\
& \text { Sun or shower, } \\
& \text { Still you find, } \\
& \text { Groundsel in flower. }
\end{aligned}
$$

Dandelions I can never bring myself to wage war with, they are so pretty, both in seed and flower. Boy, too, loves the downy blowball, and hastens to see what's o'clock by the time-honoured process of blowing at the seed-puff. Indeed, I cannot look upon them as wholly useless weeds, since their root used to be made into coffee, and in spring fresh young Dandelions make a very nice salad. But I30 


\section{"All in ye Merrie Month of May"}

although this is a common dish with the French, and I believe also with the Dutch, and used to appear on English tables in the last century (or, in order to be certain of being correct, let me say one hundred years ago), it seems now to be unknown to most English people; at least I remember taking the trouble once to collect the tender leaves and mix an oil and vinegar salad according to an old French family recipe, only to find the outlandish dish looked at askance. Although it has lovely flowers it is of no use to pick them, as they wilt directly, as I found out when, on first coming to Scotland, I plucked them eagerly, and thought them such a find in the lack of flowers in early spring. In "Hiawatha" there is such a pretty word-picture of the south wind, "Shawondasee," longing silently for the maid with hair like sunshine and, finally sighing such portentous sighs, he puffed her away for ever. "Blowballs," sometimes children call them ; while "Priest's Crown" was an old name with their elders. It is unlucky to dream of a Dandelion, but why I do not know. The Dandelion, also, has pretensions to being a weather-prophet, as there is an old belief that if the down fly when there is no wind it means rain is coming. It is curious how in far-off lands even weeds attain to honour. I have heard a story how in some Antipodean flower-show a wandering Englishman was surprised to see a humble Dandelion in a place of honour as a distinguished stranger, carefully labelled Leontodon taraxacum. After that the unhallowed reputation of Witches' Gowan, as a name it bore some time in Scotland, is scarcely worth noting in these sceptical days. Only it is curious how often yellow flowers are of an evil repute; yet yellow, the primitive colour, is the first spring tint to show. "And that's food for Hugi," or Thought.

May 8.-A real spring day; warm and sunny. We spread ourselves over the woodland banks after Primroses, and then had tea in the Rose-garden, sitting up among the Hyacinths and Tulips. There was a delicious scent of newmown hay, as the grass had just been mown. The sound of the mower sharpening his scythe is almost a lost sound 


\section{Stray Leaves from a Border Garden}

nowadays ; but in our little garden, so behind the times, it is easier to mow than use a machine, so I often hear the pleasant summery sound of the denzil or sharpening-stone. In East Anglia scythes seem to be used a good deal still. I saw a basketful of denzils in a village store one day. Boy blew bubbles all tea-time, and the iridescent soap-bells looked so pretty sailing high up in the air, and breaking in the branches of the variegated Holly-tree oragainst the house, and once on the tip of Boy's nose, to his vast bewilderment.

May 9.-Rain and, oh! so cold, one can scarcely believe it was only yesterday we sat in sunshine, in the garden now dripping and running with water in every little drift and crevice.

May I o.-A grey mist. The distant Cheviots shrouded altogether from view, and so cold I expected snow, and went out walking in a great fur-coat. It is curious to think that this is the very day when, according to the calendar, the Indian Mutiny broke out; that terrible storm out of seeming clear sky which brought such desolation to so many. Such a number of Scottish cadets of good family had wandered East to seek their fortune, the Indian disaster brought mourning to many a Border peel ; and many are the weird tales of bad omen connected therewith. I know of an old house, not so very far from here, where an old, old woman is seen to wander on the stairs, and if she point with her skinny finger at a certain door, the inmates of that room do not outlive the year. There was an officer and his wife once inhabiting that room when she was seen on the stair. The mistress of the house did not tell them about the saying, but made a note of the episode. And it is alleged that the couple were both killed in the Mutiny within the year.

May I I.-I found to-day a young rook, who had apparently fallen out of his nest in the top of a tall elm-tree. He did not know how to use his wings, so only walked away from me in a stately fashion in the grass, where I easily overtook him and stroked his head. He opened his beak to remonstrate, but apparently thought better of it, said nothing, and submitted to be caressed for a minute or two. He looked 


\section{"All in ye Merrie Month of May"}

such a curiously venerable baby with his grey head! Rooks have increased so much of later years hereabouts; they are being shot and harried mercilessly. An American tourist, seeing a flight of crows in a field near here, inquired it these were birds we preserved! A thrush has built in the wood-shed, and does not seem to mind the coming and going after the wood. I wonder if she will rear her family, or get nervous and desert them? The Blue Forget-me-not is out in the Rose-garden. It looked so pretty, Boy and I were in admiration. Boy was full of the pretty legend that, when all creation was being named, the lowly Forgetme-not, fearing it night be overlooked, called out "Forget me not." I like this name much better than the old one of Mouse-ear, or Scorpion-wort.

There is a lovely double yellow Wallflower out in the kitchen-garden, which I believe came originally from Palestine. I am not sure whether it is not identical with an old-fashioned kind called Fairy Wallflower, from the smallness of its dainty flowers ; or it may be "Harpur Crewe." Conserve of wallflower is said to cure apoplexy and palsy. The Thrift or Sea Pink is beginning to show pink buds. "Our Lady's Cushion" is a nice old name for it. I have two clumps; one came from the ruins of old sea-worn Dunbar Castle and the other from the very Hartland Point mentioned in "Westward Ho !" I had a little Linaria from the ruins of Berry Pomeroy Castle, but unluckily it died. How curious twin-flowers are! I have been busy painting a twin Daffodil and a twin white Fritillary. I saw a twin Primrose the other day. The old-fashioned Hose in Hose Primroses are rather curious too; there is a lovely clump of these in the border under the window of the Gateway Farm. I must make a raid on it. Each perfect primrose rises up out of the middle of another. There is a Hose in Hose Polyanthus. I must get it. The Gean-trees are coming into bloom everywhere, but they seem to be rather later on our banks than elsewhere. I do not know that any use is made of their fruit hereabouts, but I think in France a sort of rough cherry brandy is sometimes made 


\section{Stray Leaves from a Border Garden}

from them. I remember hearing of some nuns who devoted themselves to this industry-a somewhat curious one surely for the holy sisters, though perhaps scarcely more so than Chartreuse-making for monks, as described by Daudet in his most amusing little "Contes Choisies." I have also heard of an attempt by some old-time Scottish dames, but I fear it was not appreciated, as the recipe has not become an heirloom.

The Blackthorn is out in abundance now ; I think it is rather late. In England in old days a sort of wine was made out of the berries, called "Winterpick wine." It must have been very sour. Village children sometimes pick and eat the berries. I think it is in "The Farmer's Boy" Bloomfield describes a bird-laddie roasting the berries. Country mothers here sometimes make preserves out of sloes and scrog-apples, and the children like it. It is always cold here when the Blackthorn blooms. "Blackthorn winter" we say. Yet how pretty it is !-like a light fall of snow all over the banks or a lingering snow wreath. The Stockdove is nesting now in the woods by the Castle Loch. Cushats they call them here, a very old name for the Woodpigeon. I have heard this bird was quite unknown here twenty years ago. The Woodpigeons have been cooing about this place. I saw one prospecting the other day around the big beech. They used to be shot a good deal hereabout formerly, when they came in flocks as visitors from Norroway over the foam, thirty years ago; indeed they became such a pest that the present flourishing Agricultural Society owes its origin to an association formed for the wholesale destruction of Woodpigeons.

May I 5.-I saw the most charming border of goldcoloured and dark red Wallflowers-Bloody Warriors as they are called, I think, in Sussex; they were in the highwalled garden of an old house near here, and looked quite beautiful. There was also a row of lovely many-coloured Oxslips (Ang.-Sax. oxanslyppe) and Polyanthus. I delight in any flower of the Primrose tribe, they are so fresh and sweet and countrified, one cannot imagine them in town smoke. 


\section{"All in ye Merrie Month of May"}

The lanes are quite lovely now with Gorse and Sweetbriar (Pimpernel Rose!) and the red buds of the Golden Broom. In the Highlands I believe it is reckoned a love-charm, though how administered I do not know. It is in Ireland I think that it is called the Devil's-flower, because of the legend that whenever, during the Flight into Egypt, the Holy Family took shelter beneath the branches, the Broomtree betrayed their whereabouts by bursting into gorgeous bloom. There is an old saying-

If you sweep the house with blossomed broom in May, You'll sweep the head of the house away;

and another which declares that if the Broom is full of bloom there will be plenty corn. As to the virtues of healing with which my old Herbal credits the Broom, they are endless, and since they deal with ailments like the King's Evil, which would seem no longer to be known amongst us, there is small profit in chronicling them.

May I 7.-Rain and cold, and yet it is not very far off summertime! The Blue Comfrey, of which I found a bit in flower to-day, is exactly a month later than last year. The pale grey-blue Cushion Iris is showing its pretty dwart flowers and Solomon's Seal is slowly coming out ; there are two delightful clumps of this last in the kitchen-garden, planted in circles that have been there for many years. It is no wonder there is such a bounteous supply of this plant, since in olden days it was supposed to have singular virtue: an infusion of it in wine sodders and "glews together broken bones very speedily and strongly, though the bones be but slenderly and unhandsomely placed"; moreover, the root of Solomon's Seale, says Gerarde, "stamped while it is fresh and greene, and applied, taketh away in one night, or two at the most, any bruise, blacke or blew spots gotten by falls or women's wilfulnesse in stumbling vpon their hasty husbands fists, or such like." It was introduced into England a long time ago, before 1597. The glory of the hyacinths is departed. I nearly broke my back to-day digging up all their roots (they 


\section{Stray Leaves from a Border Garden}

seemed to stretch to the Antipodes) in order to leave the bed free for some other loveliness.

May I 8.- Rain. I am not surprised. The Cheviot Hills looked so clear and distinct and lovely in lights and shadows last night! - too lovely by far.

May 19.- There is a Tit's nest at the bottom of the old disused pump by the garden with, as far as I can see, four eggs in it. The gardener's wife says there was one last year, and it was so far down that the young birds were unable to get out, and she first fed them for a while and finally had to help them out. This was achieved with no little difficulty. There is a Hedge-sparrow's nest in the beech-hedge by the pottage-garden. This old word is probably a corruption of the French potager. An old Scotch term for broth with vegetables in it is "pottage," probably also from the French. In this nest there are several eggs. The ditch below is full of water, and the bank is marked by what Gardener expressively terms the "padding" of the children's feet as on their daily walk to school they take a peep at it. This is a very old Scotch expression. I have not seen any Swallows yet, though I believe some Sand-martins, sometimes called Bank-martins, were seen a few days ago hawking by the river. Gardener calls them Cranes, which is a curious misnomer I cannot find any explanation of. They inhabit the bank of the river under the overhanging trees. Odd old names for the Swift were "Deviling" and "Squealer," and the ancient Britons called him "Martin Du." Does that mean the Black Swallow? Certainly the Swallow has a very black back and wings, while the Martin is rather dark blue. In the "Tales of the Alhambra," Washington Irving describes delightfully how the ragged "Sons of the Alhambra" amuse themselves by angling from the battlements of the old palace for the Martlets who circle round the towers, building unmolested everywhere. Golondrino is the Spanish name for a Swallow, also the cant name for a deserting soldier.

The Arabic name for the Swallow is El Hadji, or the Pilgrim. There is a German legend, I think, that long 


\section{"All in ye Merrie Month of May"}

ago the Swallow was as sweet a woodland singer as the Nightingale. But she grew weary of being only admired occasionally by stray country folk and departed to the town, hoping to be made more of. She found, however, men were too busy to listen to her, so she gave up singing and took to building under the house-eaves. Longfellow alludes to a quaint old notion that the Swallow seeks on the seashore a wonderful stone wherewith to cure defective sight in her nestlings, and those who find it in the Swallow's nest will be lucky. There is an old Border superstition the Swallow drinks a drop of the Deil's blood every day. Still it is unlucky to kill a Swallow. I am told some of the weakly Swallows never go abroad but spend the winter here. I wonder if they remain torpid in the depths of their holes? Bank Swallows are said, if a cold-weather spell comes after they have arrived, to gather in clusters in the holes in the bank where they put their nests. I am not sure if this can be the trutb, as White of Selborne, who seems to have been a most careful observer, positively asserts they "do not make use of their caverns as hybernacula." It was certainly a belief in olden days Swallows hybernated either at the bottom of ponds (!) or in clefts of rocks, or, in America, in hollow trees, called Swallow-trees. I have tried in vain to investigate the Bank Swallows' homes; here they run in too far for me to see anything.

There is an old Border saying, which runs thus :

\footnotetext{
Seven sleepers there be,

The Bat, the Bee and the Butterflee,

The Cuckoo and the Swallow,

The Kittiwake and Corncrake,

Sleep a' in a little hollie.
}

And it is often a matter of speculation with gamekeepers what the "paitricks dae wi' themselves all winter," since a certain number of partridges yearly escape being shot, and are never seen about afterwards.

The Bluebells, or Wild Hyacinths as they are called here, are beginning to show, and the sweet white Woodruff is in bud. 


\section{Stray Leaves from a Border Garden}

The Bluebells are sometimes called also Crawtaes. I think this is a Galloway name if I remember right. I planted some seeds of the grey-blue Asperula last year, but apparently they have not come up. Next year, I think, I shall try putting out grown seedlings. Woodruff is from the Saxon word Wuderofe, or Woodrow, meaning woodsweet. Woodrowel was a name in use in Queen Anne's time, probably from the likeness to a spur rowel. People used to put little dried flowers of Woodruff-Sweetgrass as it was called hereabouts-in old days inside their watches. The song "Bluebells of Scotland" is said really to refer to the Blue Harebell, of which there is abundance later in the year; Hairbell(Campanula rotundifolia). CarolineSymmons, in 1788 , wrote such a pretty poem about the Harebell.

Sir Walter Scott calls the Harebell, Bluebell. Here they are sometimes called Ladies' Thimbles and Our Lady's Thimble. A pretty French name for the white Harebell is Nonne des Champs.

I like an old story I once heard that they are called Harebells because the Haresring them to tell eachother which way they have passed. Certainly I have seen the tiny bells quivering. Witches' Thimbles is another name for the Harebell, which, however, in Teviotdale is given to the Foxglove. And, alas! whether they used them or not, witches are said to have haunted the Border; and not many miles from here, near the Castle Loch, is a Beech-clad hill where, tradition declares, the Last of the Witches was burnt to death. To dance a reel was at one time considered a sign of a witch. This seems curious when one considers how fond Scotch people are of dancing and of reels. "Cummer goe ye" is the name of a reel known as the "Witches' Dance." There are many dark stories about witches, and more than one hamlet hereabouts is credited with having been inhabited by witches. The "Ill Man " must, however, take but poor care of his "ain," since his votaries always seem to have been very poor and miserable. There is a hill I know of, still called the Witches' Knowe, where in the last century two wretched old carlines were burnt to death, 


\section{"All in ye Merrie Month of May"}

while the fierce and credulous bystanders looked confidently to see the Deil come in the form of a Corbie Craw and fly away "wi' his ain!" It is curious to look at the quiet, sober folk gathered every Sabbath in our little ancient grey kirk, and think how their forebears could be so cruel and lawless. The worst one hears now is of mole-catchers stealing bicycles, or poachers and water-bailiffs having frays on the banks of Tweed.

About I 634 there was a most celebrated witch called Betty Bathcat. The story of her indictment may be read with other curious matter in a book called "Pitcairn's Criminal Trials." They were said to use many strange charms, some of them not unlike those of the Obi women of the present day in the West Indies. There are documents, I believe, still preserved on the heavily-laden shelves of the Advocates' Library in Edinburgh, showing that the Privy Council were in the habit of granting commissions to gentlemen and to ministers of parishes all over Scotland to examine, try, and execute witches. But I suppose we should not judge too hardly the old-time justices who passed sentences or the villagers who carried them out, since within the last ten years, in spite of all the muchboasted enlightenment of this nineteenth century, a poor old wife was accused of witchcraft in Ireland by her own folk! And a case somewhat similar occurred in Galloway, and, I believe, many a cottage cradle may be found in Wigtonshire and Galloway with the big ha' Bible hidden under the pillow when the baby has to be left awhile alone, that the baby may be there when the mother returns, and not have been spirited away by "those we dinna mention." The fairies seem to have frequented here in the same neighbourhood where the witches were rife, if the tale of the herd's wife of "Little Billy" is to be credited, who was carried off in a sheet by the "gude neighbours." She had forgotten, when her baby was born, to put either the big Bible or her husband's breeks (an equally effective safeguard apparently) on the shelf in the box-bed, and so was stolen away. The Scotch fairies, as also the Cornish 


\section{Stray Leaves from a Border Garden}

fairies, seem to be partial, by all accounts, to mortal nurses for their infants, and lose no opportunity of stealing newmade mothers therefor. In this case the wretched husband rushed after his Maggie, crying on the fairies to let her go in Heaven's name. They were obliged to drop her, but her spirit remained "mazed." She took " no interest ever after in any mortal thing, not even her own bairns"; she just "dwaumed away," and died shortly afterwards.

At Billy, the burn called the Drædan Burn, over which the fairies tried to carry Maggie, is said to have been named after the Druids, and there were granite blocks there within the memory of man which wise men say formed part of a Druidic temple. The Cowslips I got from Weymouth have now taken to their new quarters wonderfully; they are throwing up giant spikes of bloom. Petty Mulleins is a nice old name for them; they are also called Herb Peter ; and Cowslip wine, which does not seem to be made nowadays, is said in my old Herbal to be "Cordial and Confortative, and refreshes the Spirits," and a Cowslip tincture is recommended as excellent in Palsy and divers other ailments, whence the Cowslip is also called Palsywort, a mere translation of Herba Paralysis. My other colony of Devon Daffodils, called Lent Roses in Devon, have never come up at all, nor has the big grey-eyed Provençal Periwinkle: I suppose it found this climate too cold. I planted last year a row of Grape Hyacinths, sent from a vineyard in Southern France, where they grew beautifully under the old crooked Olive-trees, and one tiny solitary bloom has come up, looking like a fairy flower, so very small is it. A few yards away there is a splendid bloom of the same, but this plant is home-grown, having been transplanted from a neighbour's garden-plot. The ferns are beginning to sprout; their curled-up leaves, looking like green Bishops' Croziers, are to be seen under every bush now. A quaint old scotch expression for sunburn or freckles is to be "fernitickled," because of the likeness to the seed-spreckled back of a fern.

In the "West Country" there is a belief that the first 


\section{"All in ye Merrie Month of May"}

fern seen in spring is a sure cure for toothache, provided you bite off the top. Shakespeare and Ben Jonson have curious allusions to an old fantaisie that fernseed carried in the pocket rendered the bearer invisible. This belief also prevailed in Scotland and in Germany. I gathered a great beaupot of Wild Cherry blossom to-day, and a perfect sheaf of Sweetbriar; it quite scents the house; so, if we are not cheerful we should be, as it is said to promote cheerfulness. Anchusa Italica (Alkanet) is in flower. I wonder how it came into this Scotch garden. With us it has escaped from the kitchen-garden out on to the riverside haugh. I have seen it in one farmer's garden near here and in an old churchyard, but I do not think it is common. It is probable that some of the plants which seem to be naturalised foreigners or garden escapes, may have been introduced by the Saxon monks, who seem to have cultivated a variety of medicinal and potherbs in their gardens. It has been asserted that more than three hundred kinds of medicinal plants were in use by the monks, and that many of the names they gave have been changed for other names, sometimes less appropriate, just as if the Protestant iconoclasts, to whom we owe the destruction of so many beautiful church buildings, had extended their destroying rage to the herbs whereby the maligned religious orders benefited the sick. In the British Quarterly Review, I85 I, may be found the following list of plants cultivated in the garden of a Saxon convent : Peppermint, Pansy, Sage, Rosemary, Rue, Pennyroyal, Cummin, Watercress, Fenugreek, Cornflag (our Gladiolus), Loveage, Fennel, Savoy, Roses, Kidney Beans, and White Lilies, Poppy, and Coriander. At Coldingham Priory, about eighteen miles from here, there was a large flower-garden before I259. Judging by the plans of other early monkish gardens, the vegetables were probably grown in a separate part from the flowers and herbs, this part being generally known as the Herbarium, or Herbere by the common Scots people. King David I. is said to have taken great pains to encourage gardening amongst the monks, and was no mean gardener himself. 


\section{Stray Leaves from a Border Garden}

Another mediæval royalty who was fond of gardening was, it is said, Charlemagne, who liked visiting the Abbey of St. Gall, on Lake Constance, and gardening with the monks. The plan of this Abbey, dating from the ninth century, is still to be seen, showing the different gardens. Oddly enough, this plan of separate flower and vegetable gardens seems to be favoured in Virginia at the present day, where the kitchen-gardener apparently does not care to work among the flowers. There is a tradition, I believe, noted by Camden, that in the neighbourhood of the Picts Wall the Roman soldiers quartered on the Border introduced plants good for healing wounds. In this category surely the Soldier's Herb, or Sideritus (Ironwort), should be included, for herbalist lore declares that "it did cure Wounds made with the Sword or with Iron," and, indeed, seems to have been a thing no surgeon should ever be without.

The monks of the Middle Ages were practically the only chirurgeons, and this is why the herbs were generally to be found under the shadow of monastic walls, though sometimes in secular precincts. Brithnod, Abbot of Ely in I I07, took great interest in plants and trees, so did Erasmus and Luther. Abbot Neckam (I213) fosterbrother of Richard Cœur de Lion, was also noted for his interest in gardenage, and has left a list of the things he considered should be in every good garden, quoting particularly a long list of " pottageherbs" and Roses, Lilies, and Peonies. But since it is much the same as the Saxon conventual list I will not note further.

The purple spires of Honesty form the principal beauty of the garden borders just now. Such a number of quaint names this plant has-Satin Violet and Sattin-flower, names it bore in Gerarde's time; Lunary, Moonwort, Pennyflower; while the French call it Lunaire and Médaille du Pape. There is a white kind not so pretty as the purple, which is certainly handsome if a trifle coarse, like the beauty of a storm-tanned gipsy ; but it is not to be despised, this backward season especially. There is a delightful old saying 


\section{"All in ye Merrie Month of May"}

that, wherever Purple Honesty is found, the cultivator of the garden is an Honest Man! It was also recommended as keeping off evil spirits. In winter the silver seed-vessels make pretty bouquets for the empty flower vases, along with the dark green of the yew. How pretty the old Apple-trees look with their pink buds and opening flowers! They are the ladies of the kitchen-garden, as the Birch is the Lady of the Woods. Merlin, that most ancient Scottish poet and warrior, describes beautifully an orchard given him by the king as a guerdon for his prowess.

"Seven score and seven are the fragrant Apple-trees, equal in age, height, and magnitude, branching wide and high as a grove of the forest, crowned with lovely foliage, growing on the sunny slope of a green hill, guarded by a lovely nymph with pearly teeth." Although, for fruit-bearing, I fancy very elderly Apple-trees are not so much appreciated as younger ones, yet the hoariness of age given by the lichens to the gnarled old ancients is very beautiful. I heard of a lady who went to Court the other day in a white brocade trimmed with bunches of Apple-bloom. It is so inimitable in painting. It must have looked lovely if the wearer's face was at all in keeping.

May 22.-There is a Swallow's nest over the top of the coach-house door ; it is so funny to see the Swallows peeping out of the clay-built lumps, all the little heads with open mouths! I like the pretty Roman legend that Swallows are the spirits of dead children come to revisit their homes. Certainly House-swallows seem to love to be near men. Do Swallows sing? It would seem a vexed question. There was a curious controversy the other day in the paper, but the question was not settled. White of Selborne says the Swallow proper is a delicate songster and sings both perching and flying, but that House-martins only twitter. I don't quite agree in this last, since I have been awakened in the early morning by such sweet twittering as almost to merit the name of song.

The Swift squeaks and shrieks, whence he is sometimes called the Squealer, and the little Bank-martins hardly make 


\section{Stray Leaves from a Border Garden}

any noise at all. Certainly I have watched the latter often and never heard a sound. It is curious that the old saying, "One swallow doesn't make a summer," seems to have been current among the Greeks, only I think their wording was, "One swallow does not make springtime." The Spanish version, according to Cervantes, was, "Una golondrina no pace verano," while the Italians say, "Un fiore non fe primavera." The Swallows were hawking very low over the river to-day, so it will probably rain to-morrow. This as a sign of rain is noted by Virgil in the "Georgics," as also by the Greek poet Aratus. One can count on fair weather when they fly high. In Rhodes it used to be the custom for children to go from door to door in the early days of Spring carrying a Swallow and singing a little song which ran somewhat thus, I think:

See here the Swallow,

See here the Swallow

With dusky wing and breast snow white,

She brings the Springtime young and bright.

I believe, in a charming prose book of Longfellow's, too little known, he alludes to this custom, and, I think, has given a poetical version of this child's song. The old Greek poet Athenæus in the "Song of the Swallow," gives a pretty version of it.

There is an old saying here :

Quick, quick, the Swallow comes,

Keep your arms close,

For if she touch them wi' her wings,

You their power will lose.

There is a quaint old Provençal poem called the "Virgin's Cradle Song," which shows that in Provence the Swallow was not always a welcome guest-le bien venu:

O sleep soft, my Jesu,

From the mountains to-day,

To rest in thine arms

The Dove wingeth her way.

I have brought thee fresh straw,

Thy poor sheets I've washed white,

Thou'lt sleep softly, my Bird,

In thy cradle to-night, in thy cradle to-night, 
"All in ye Merrie Month of May"

I would sing thee to sleep,

But no strength my voice knows,

And under my hand

Will thine eyelids ne'er close.

$\mathrm{Oh}$, little dark swallow,

What dost thou want here,

Thy black robe bringeth fright

To the soul of my Dear.

Like a dark gloomy pall

Thy wing shadows His bed,

And my heart groweth sad

With each circle o'erhead.

My child, art thou wakeful?

See, the Swallow flies away ;

So sleep softly, my Jesu,

The Dove comes to-day.

It is curious that in Virgil's mention of the Swallow he uses the same epithet of "nigra" or dark, as follows :

Nigra velut magnas domini cum divitis ædes

Pervolat, et pennis alta atria lustrat hirundo.

As a child I remember once being highly delighted with a young Swallow falling down the chimney of an old Italian house where I was staying. I took it into my bed (I did not know much about the natural history of Swallows!) and tried, by warming it, to recover it of the shock. But in vain; it died the next day, and had to be buried with honours. Dr. Hardy, a well-known Border naturalist, gone from among us, alas! now, is credited with the following story: A man who wanted to know where the Swallows went in the winter, caught one and tied round its neck a card with the words "Kimmerghame Mill " on it. He then let it go. The following year the bird came back with the addition: " River Nile, Egypt."

Fay went fishing to-day, and I attended her with the creel and landing-net. Cold, very cold by the river; I found it difficult to believe it was really the end of May. A dear little Willow-wren attended us along the bank, hopping on the leafless branches of some Ash saplings by the water. Surely a curious day to choose for shearing sheep, 


\section{Stray Leaves from a Border Garden}

but I saw some had been shorn and, looking like sheep out of a toyshop, were spreading themselves over the fields beyond the river. The purple and white Lilac is almost out; a few days warm sun will bring the flowers forward. It is curious we should use the Persian name for it, Lilag, scarcely altered. The French Lilas and Italian Lila is almost the same too; so is the Spanish Lila. The German name is Spanische Flieder. The Leopard's-bane (Doronicum) is beginning to star the wood with its golden stars. It is said to be a desperate poison, and gets its name from having been used formerly to poison wild beasts, a use to which it is not very likely to be put in England. Panther-bane is another old name for it. The French name is Mort aux Panthères. Ben Jonson, in his "Masque of Quenes," mentions Leopard's-bane or Doronicum, spelling it, however, Libbard, the same quaint spelling used by Shakespeare.

May 25.-A fairly fine day but cold, with an easterly wind. I can never feel in sympathy with Kingsley's praise of the East-wind. Rather would I sing

When the wind is in the East, 'tis neither good for man nor beast. The Nettles seem the only things which flourish apace, and do not appear to mind the backwardness of the season. And yet such weather has not been known for upwards of thirty years. The Spring vegetables are so few and small, I should think seriously of trying to boil young Nettles, but that I fear no cook would consent to cook them, and I very much doubt finding any one to eat them when cooked. Even Soyer tried in vain, I believe, to make people see the excellence of young Nettles as a dinner dish. It is curious what odd romance and fancies there are about the apparently prosaic Kailyard, unsuspected, I imagine, by most people. For instance, the homely Onion used to be an object of worship by the Egyptians somewhere about 2000 B.c., probably for its virtues. Even now it is sometimes recommended as a cure for divers maladies-a roast onion in the ear for earache, and for deafness the juice, while to dream of onions warns one of "Strife in Thy I 46 


\section{"All in ye Merrie Month of May"}

Domestick Scenes." In Roumania I have been told there used to be a practice called the Onion Kalendar. Overnight twelve onions hollowed out were put in a row and salt dropped into each one, they being named during the process after the twelve months of the year. In the morning those onions wherein the salt has melted show which will be the rainy months. A cooked onion is said to bring back voice lost from cold; it is also "good for the Biting of a Mad Dog, Serpent, or any other Venemous Creature, being laid thereto" ; while " the liquid Juice will cure Baldness" ; and many other medicinal virtues the humble Onion would seem to have, even to "the causing of Crocodiles" tears when desired." Peas were held in high repute, and there is an old saw advising us to eat peas with the King and cherries with the beggar. Water in which peas were boiled was deemed a cure for measles, while Pease-broth, " made good and strong with Knuckle of Veal and Legs of Pork, wonderfully Restores in Consumptions." Peascod-wooing used to be practised long ago, and is mentioned by Gay in his poems. If a maid shelling peas happened to find a pod with nine peas in it, and laid it on the threshold of the kitchen-door, the first man who stepped over it would be her future lover. Codde is an old Anglo-Saxon word for " bag," in Icelandic Kodde a pillow ; a pillowslip used to be called in Roxburghshire long ago a Codhule; and Codde, indeed, survived in Scotland for a long time, so a Peascod is just a bag of peas. Stow describes delightfully a City of London madam as having dyed red hair, decorated with a hood of muslin and gold threads, and open peascods with pearls doing duty as peas. Peas were considered rather uncommon dainties in Queen Elizabeth's time. I am not sure they were not introduced then, which may account for Queen Elizabeth's odd fancy for having a white satin spencer all embroidered with green peapods left open to show the peas within. There were Butterflies, too, on this lovely garment. There is something very fascinating about a peapod. I was once given a China one, of delicate green, half open, disclosing a row of tiny children's heads. "Made in Germany" 


\section{Stray Leaves from a Border Garden}

was the legend; I would rather have thought Denmark, since in Andersen's "Fairy Tales" the peascodis so pleasantly introduced. I always liked the story of the five brothers who lived in the one codd. The French Mange Tout Pea does not seem to have travelled this far; I am going to try it this year. (Note.-It has been a great success, and recommends itself to the cook by not requiring husking, and to the gardener by reason that a smaller quantity is required to content the cook.) Mange Tout Peas are not to be found in every one of the many attractive nurserymen's catalogues, but under the name of Tall Sugar may be obtained of Sutton, the well-known king of seedsmen, at a fair price. Beans (Ang.-Sax. Bean) are a nice vegetable, and so pretty! I love the arbours of scarlet and white Runners to be seen in cottage-gardens. Both Haricots and Broad Beans make most delicious soup. Beans seem to have played a part long ago in love-charms, and the pretty fantasy of King of the Bean was introduced into Scotland by Mary Queen of Scots, and, I think, was a practice at Queen Elizabeth's Court likewise. Lucky Beans may still be seen on watchchains and bracelets, and I remember as a child cherishing for a long time a tiny white china bean with a face upon it, which came out of a French Twelfth Night Cake. I used to delight in the old German story of the Bean, the Straw and the Coal on their travels, so cleverly illustrated by Walter Crane, relating how the Bean was so amused at the misfortunes of his fellows he laughed till he burst, and had to be compassionately sewn up by the kindly tailor, but with black thread-hence the black mark in the Bean, and the old saying, "Every bean hath its black!" which is much the same as the old saying, "A thornbush grows by every man's cot." In Leap Year it is said all the Peas and Beans grow the wrong way in their pods, as it is the Ladies' year, and women are supposed to do all things contrariwise. The Bean is dedicated to St. Ignatius Why, I do not know.

It used to be considered very unlucky to sleep in a Beanfield, and there is a Leicestershire saying, "If you $\mathrm{r} 48$ 


\section{"All in ye Merrie Month of May"}

want to have bad dreams or go crazy, go sleep in a beanfield." There was an old belief that in Bean-flower time people were more apt to grow crazy. Certainly an acre of Beans in flower fills the air with a very strong smell, almost too delicious. Some people dislike it. I like it. Water distilled from Bean-flowers is said to take away freckles and sunburn, and as to the virtues of the Bean as food, "they are so many I will refrain from setting them down lest I weary me." The Potato in its neat rows does not look very romantic, and even less so in heaps preparatory to being stacked and covered over with earth. But if you carry a potato about your person, it is a Scotch belief you will not suffer from rheumatism. Curiously enough, it was a poor pedlar called Prentice who is said to have started growing potatoes in fields in Scotland. He died in $\mathbf{I} 788$. It was deemed at first a vegetable of evil tendencies, and was not always a persona grata in consequence in everybody's vegetable-basket. There is a curious mention of potatoes as being half-a-crown a peck in an old accountbook of the Duchess of Buccleuch and Monmouth, I 701 . I believe this is the earliest known mention of potatoes in Scotland.

There is a quaint old saying about folk who look for impossibilities : "Wad ye hae taties grow by the potside?"

It is curious that Potato is said to be a corruption of Patatas. I suppose old Spanish, as they were introduced from the Spanish Main by Sir Walter Raleigh, and to this very day the sweet potatoes, a sort of yam, of the West Indies are called Patates by the French. Pataties is the Scotch name for the ordinary potato. There is an edition of Gerarde's Herbal, with a picture of Gerarde with a potato in his hand, I suppose because it was such a valuable find. It is said to be very good against consumption and many other ills. It has sundry funny local names, such as Red Eyes and Leatherjackets, also Blue Eyes, and, curiously enough, is cousin, as Boy would say, to Tomatoes and my beloved Winter Cherry, with its orange seed-vessels, and to the Petunia. The Potato-flower is very pretty, and at a 


\section{Stray Leaves from a Border Garden}

pinch fills a flower-vase, I think, very prettily, and is not always recognised. I have tried fried Parsley as a vegetable, much to the surprise of Cook and Gardener, and very good it is. A Parsley-bed, according to an old saying, used to be considered the place to find newborn babies, and among interesting family records of the Earls of Marchmont, still preserved, is the following verse written by a boy of seven or eight on the occasion of his elder brother's birthday:

This day from parsley-bed I'm sure

Was dug my elder brother Moore,

Had Papa dug me up before him,

So many now would not adore him.

But, hang it! he's but only one,

And if he trips off I am Sr John.

See "Marchmont and the Humes of Polwarth" by one of their Descendants, for further details. Persil as the Scots used to call Parsley, is very widely considered unlucky, and it is especially deemed unlucky to sow it or give plants away, though I believe you may steal it with impunity, the reason given being that the seed had to go to the infernal regions and back ere it could grow. It was used to deck graves among the Greeks, and there was a saying "To want parsley," which meant a person was at death's-door. The Romans believed it had the power of rendering the fumes of wine innocuous, so they used it in garlands at parties. The Greeks also crowned their victors with parsley. In Devonshire there is an idea that, if you transplant parsley, the fairy of the parsley-bed will be angered and ill-luck will overtake you, and there is a saying, "Where Parsley's grown in the garden there'll be a death ere the year's out."

It is curious that, long as it has been known in British gardens, there is no certain knowledge whence it came first. It must have been precious not only to cooks but to herbalists too, since there is a lengthy list of diseases it vanquishes in my old Herbal, and specially is it powerful against "Poyson and the Bitings of Mad Dogges." Our ancestors would seem to have been much troubled with serpents and mad dogs, since there is hardly a plant 


\section{"All in ye Merrie Month of May"}

which is not a specific against these ills. The Pasqueflower (Pulsatilla) is called Parsley Laughing in my old Herbal for this reason: It kills by making the Patient look laughing all the while, whence it obtained the name of "Apium risum." And yet, notwithstanding, the Standers-by may think the Patient is really a-Laughing or in a Laughing Humour, there is, indeed, no such thing. It only by its Poisonous qualities hurts the Senses and Understanding, thereby causing Foolishness, and Convulsing the Nerves, especially of the Mouth, Jaws and Eyes, draws them this way and that way, and sometimes in a manner all ways, making the Sick seem to the bystanders as if he continually Laughed, and so the poor Patient dying in this condition, the lookers-on Think he dyes Laughing and so report it; when at the same time there is no such matter, but he goes out of the World under the sense of violent Convulsions, vehement Pain, and the most extream Torment imaginable. But the chief use that is now made of these Flowers is for Ornament Sake, more than anything else, and to set off and Adorn a Garden, among such as are curious and delight in things of this Nature, they being very beautiful in their kind." It is called Pasque-flower because it flowers at Easter. It is delicate, but has been grown successfully in this neighbourhood out of doors, so I think I must try, though I fear the river-frosts will not be good for it. Carrots are rather nice vegetables I think, their Leaves are so pretty, and when they are brown look so graceful mixed with green, in flower-vases on the dinner-table, mixed with Marigolds or Zinnias, or with Escholtzias. I am so fond of Escholtzias - the Californian Poppy as some people call them. But I prefer the golden variety to all others. The Saxon name for Carrots was Bird's-nest, and I believe it is still a common German name, Vogelsnest. Bird's-nest is a Scottish name of old standing for the Wild Carrot. Gerarde says the reason was that "the whole tuft is drawn together when the seed is ripe, resembling a bird'snest, whereupon it hath been named of some Bird's-nest. It was also called Bee's-nest. He also says Carrots, more 


\section{Stray Leaves from a Border Garden}

especially wild ones, were good as love-charms. The present garden carrot was, I think, introduced in the days of Queen Elizabeth, and the ladies thought so much of it they decked their heads with its leaves. Carrots prepared in different ways were valued in medicine as "cures for Spotted Fever and the Bites of Rattlesnakes." But since neither of these ailments seem likely to come my way, I do not think I need note the recipes. Carrot soup is truly a most excellent thing, and Carrot and Tomato soup, though less well known, is also, I think, very good. The Turnip is called here Neeps. Turnip-juice extracted from the sliced root and brown sugar-candy, baked in an oven, used to be deemed a cure for coughs and consumption. An old name for Turnips was Knolles, probably from the Danish Knold, a tuber. But my wanderings round the Kailyard threaten to become interminable, still I cannot pass the Cabbage-bed without thinking of the old saying, babies are first found in the Cabbage; it looks such a nice snug nest for a newborn Baby; indeed, I remember once seeing a baby's smiling face shown peeping out of the greenleaf folds of a tiny china cabbage in an ancient china closet. I heard once of a Robin building his nest in the heart of a Cabbage. The Cabbage-stocks, uninteresting as they look, are said to be the horses on which the Scotch fairies ride by night. There is an old North-country superstition that, if a maiden wants to see her future husband, she must go alone into the garden on Hallowe'en and pull up a Kailstock. If she chance on a tall straight one, such will her lad be; but if she light on a poor crooked stump, such in appearance will the future husband be.

The Egyptians built altars to the Cabbage, and the Romans as well as the Greeks had a high opinion of its virtues. If I remember right, Cato sang its praises, while Diocletian's preference of cabbage-tending to empiretending is well known. I think it is Cats, the Dutchman, who says somewhere it cured all illnesses-a delightfully comprehensive statement, beside which the modern Irish notion that a cabbage-leaf is a cure for sore- 


\section{"All in ye Merrie Month of May"}

throat when tied round the neck of the sufferer, is nowhere. The Cabbage was introduced into England about I570; indeed, before then vegetables seem to have been little known; but whether it was actually known on our Borderland then I do not know ; very likely, since Mary Queen of Scots seems to have tried to improve the Scotch dietary on her arrival from France, and introduced sundry vegetables in use in France-chicory and French sorrel, for instance. In Lettuce-beds an old belief declared evil spirits lurked. The Saxons called this plant Sleepwort. Lettuce, especially Wild Lettuce, is said to be a sovereign remedy in one respect, it "resists the Poyson of the Spider." . . . I wonder what particular spider ; though, to be sure, all spiders are a little poisonous, yet English spiders I do not think are harmful to people of larger size than Tom Thumb, with whose sad duel with the spider we are familiar from our nursery days. It is recommended as salutary food, being cooling, for persons who are hottempered. Lettuce stewed in brown gravy is a very nice dish, not very commonly known, I think. Endive and purslane are powerful love-charms, and Gay talks of the "Endive blue" being used to deck graves along with Rosemary-Old Man as it is sometimes called; I don't know why.

Beetroot and Cucumbers were reputed cures for hydrophobia. The tall graceful Fennel has some curiously contradictory associations. The Greeks and Romans seem to have prized it, and crowned victorious gladiators with it. More modern folk deemed it unlucky, as there is an old saying, "If you sow fennel, you sow sorrow." It was dedicated to St. John, and was also credited with being a good tonic. The old-time monks appear to have used it largely; no herbarium ever was without it. But the Leek is the King of the Kailyard; ever since the days of the Saxons it has been a valued inmate of all gardens, and even gave its name to the kitchen-garden, while the gardener was called the Leekward. Leeks and barley and milk make a very good sort of Scots broth, improved, I 


\section{Stray Leaves from a Border Garden}

think, by a few dried prunes, an innovation which my Scottish cook regards with surprise. "Cocky Leeky," the apotheosis of an old cock, with Leeks (and prunes), \&c., is almost a world-famed dish. It would seem to have been thought a very hardy plant, since in the account of the great frost in 1608 it is recorded that " the Leek, whose courage hath ever been so undaunted that he hath borne up his lusty head in all storms, and could never be compelled to shrink from hail, snow, frost or showers, is now by the violence and cruelty of this weather beaten unto the earth, being rotted, dead, disgraced, and trod upon." I asked Gardener if the Leek was indeed very hardy, and whether it minded snow and frost, and he said he thought not, only it was not possible to get any out of the ground in hard weather, and if there was deep snow it could not be picked for fear of the leaves breaking off. The Jacobites sang of the Kailyard, of the wee wee German lairdie delving in his Kailyairdie, streughing kail and laying leeks, whose thumbs the Scots thristle was to jag. There used to be an old rhyme popular with Border Bairns :

\footnotetext{
Sunny shower, come on for half an hour,

Gar a' the hens cour,

Gar a' the hares clap,

Gar ilka wife o' Lammermuir

Put on her kail pat.
}

Kail, though applied indifferently, I think, now to anything of cabbagekind, properly belongs as a name to the Colewort. Curiously enough, in modern Swedish a Cabbagestock is termed Kaalstok. I rather like the Scots name for Catterpillar-Kailworm. Sproutkale the Saxons called February, while it was the old Dutch, I believe, who called it the Thawing month, Sprokkel maand. Barefoot Kail is rather an amusing term for a poor Scots starveling's broth made without meat. The far-famed Jenny Geddes was a greenwife or kailwyfe at the Tron Church in Edinburgh; in other words, a greengrocer with a stall. The pillar is still pointed out in St. Giles' Cathedral by which she sat on her creepiestool. 


\section{"All in ye Merrie Month of May"}

Artichokes, or, as the name used to be written long ago, Hartichoak, are, I think, such a lovely picturesque vegetable with their jagged grey leaves and the wonderful flower which comes if you leave the globe alone. It is strange how many people seem, like Hans Andersen's noble in the fairy tale, unacquainted with this splendid blue Lotus of a flower. I delight in the story: how the gardener, in despair for something effective, sent up to the Castle this big blue flower, and all the folks were agog to know what it was. The tall yellow flowers of Jerusalem Artichokes are also very decorative. Alas! the Jerusalem Artichoke never flowers here. And I am afraid my opinion may not be worth much, since I confess to having been found admiring a Cabbagestock when in full flower ; and for fields of Mustard and Charlock, looking like golden sheets, I have always entertained a deep admiration. I love a bright patch of anything, anywhere. Down by the tennis-lawn the selfsown patch of French Forget-me-not, which is generally like a blue cushion, is almost over; it seems scarcely to have had any flowers at all this year, owing, I suppose, to the lack of sunshine and warmth at the right time. I have only had one good bunch from beneath the Gean-tree, which is generally a preserve for the loveliest skyblue bouquets from March almost to May.

May 26.-On the topmost sprays of the old Lilac-trees, near the Rose-garden, there are purple and white plumes waving high above the laurels and quite out of reach, but looking lovely. It is quite light now at 9 o'clock in the evening. We watched from the window our big grey Tom Cat with a young Rabbit. It was just like the description one reads of some beast of prey. He let it go a little and then dashed on to it, and shook and tossed it. Finally, I could not bear it any longer, and sallied out, with a stick, to interfere. But, before I reached the scene of action, Puss and his victim were gone. I fear me it is not the first time Puss has so offended the gamekeeper. It is a pity he cannot turn his attention to rats versus rabbits. We are greatly plagued with rats; I believe they have 


\section{Stray Leaves from a Border Garden}

always been very plentiful hereabouts, and until now I have never discovered what use they are. But now I learn their presence indicates sound healthy surroundings : that there have been weil-authenticated cases where the rats have been seen to decamp in a body just prior to an outbreak of typhoid fever in the place they left. So we may look upon them as a sort of sanitary inspectors. Rats and nettles seem somehow always to go together. I heard the other day of a delightful tale of some fellow who is going about the countryside professing to charm rats away from any dwelling-house, but-there is always a "but"-report also says that this modern Pied Piper of Hamelin always leaves a few behind! If we continue to be so pestered with them as we are at present, I think I will try the Leopard's-bane on them. If it professes to kill a Libbard, methinks it will surely dispose of a rat. Briza Media grass, called here "Peeseweep grass," is known as Trenbling Jockeys in Yorkshire, and there is a saying

\section{A tremling Jock i' the house}

An ye weeant hev a mouse,

but I don't know if this applies to a rat. I am afraid it can scarcely be potent enough, as I have had bunches of it in the house often. Dried and hung up, it is supposed to keep off ague. Rats are excessively cunning, and it is very difficult to get quit of them. They are my despair in the garden and greenhouse. One year they ate a whole set of choice bulbs, and they riddle the rockeries with holes, and are afraid of nothing and nobody, actually getting into the pig's-trough and eating up the food before poor Chig's very eyes! By-the-way, I find we cannot keep any but white pigs; there is no sale for black pigs, they are considered so unlucky! I am rather sorry, black pigs are so much prettier. I remember the dearest little black pigs about the farms in Devonshire scurrying in and out of the Appleorchards. Boy showed me a Waterhen's nest, scarcely more than a depression in the ground among the dry leaves. Down by the river there is a Thrush's nest in a I56 


\section{"All in ye Merrie Month of May"}

Syringa bush in Middle Path, with four unlovely gaping goblins in it, and a bright-eyed mother who keeps a wistful look-out on all passers-by. I saw some Cuckoo-flower (Cardamine pratense) to-day-Ladiesmock as Shakespeare calls it-but it is not so plentiful here as to paint the meadows. Cuckoos, by-the-way, are called Gowks here, and Godscroft, where lived Home, the historian (not David Hume), but likewise a Border worthy, one of our Homes of Wedderburn, is said to have been originally Gowkscroft, because there were so many Cuckoos there. Woodsorrel, which grows sparsely with me, though freely in some of the woods about here, notably at a place called the Cats-stairs, is called also Gowksmeat, which local name curiously resembles the Swedish Giokmaal. In England it is called Cuckow's-meate and Cuckoo-sorrel, from an idea the Cuckoo cleared its voice when husky by eating it. It is sometimes called "Hearts" hereabouts. It is said in Ireland St. Patrick took a leaf of Woodsorrel, called in old days Shaenrog, to illustrate the doctrine of the Trinity, and in consequence it is sometimes called the Trinity-flower, though the Trefoil (Black Nonsuch) also claims the distinction of being the true Shamrock. The Sorrel is called also Alleluia-flower, because it blooms between Easter and Whitsuntide. It used sometimes to be eaten as a vegetable, but everybody is not partial to the acid taste of its leaves. A common French name is Oseille de Bucheron-at least in Auvergne, where it grows freely; and Pain de Coucou and Surelle. Juliola is the Italian name, and Kuckkuckslee the German. In Wales it is called Fairybells, because the fairies are supposed to ring them to summon each other to their midnight revels. In Jamieson's Dictionary I find the following curious notes concerning the Cuckoo or Gowk, as they call him here: "In some parts of Scotland he is called Gock and Gouckoo, and in Icelandic Goukr, in Danish Gjoge, and in the old Swedish language Goek. Cog was the old British name. In Fife, people given to vagaries and causeless changes of purpose are said to see the Gowk in their sleep, while a Gowkstorm is used both literally-meaning two or three days 


\section{Stray Leaves from a Border Garden}

of rough weather, believed to occur in the beginning of April or rather at the time when the cuckoo is first heard-and metaphorically, to signify an evil which does not last long. The earliest English song, I believe, known, dating back to the thirteenth century, is the old one:

Summer is icumen in, Loudly sing cuckoo, Groweth seed and springeth mede, And springs the weed anew.

It is curious how many plants are associated with the Cuckoo beside the Woodsorrel. Ragged Robin, called also Cockskaim and Meadow Pink (Lychnis flos-cuculi), is sometimes called Cuckoo-flower, a name more often given to the Cardamine pratense, or Lucy Locket. Canterbury Bells are sometimes called Gowkshose, a name given to the Bluebell or Wild Hyacinth in Dumbartonshire. In Ayrshire the Polytrichum commune, or Great Golden Maidenhair, goes by the name of Gowksbear, while in Lanarkshire the Yellow Rattle (Rhinanthus cristagalli) is the Gowks-shilling. Gowk is also a term for a fool, and to "hunt the Gowk" means to go on a fool's errand. I heard a Cuckoo calling in the Devonshire lanes at Eastertide, but have not heard one here yet. It is such a nice cheerful sound, so full of Spring ! but Spring as she should be, warm and fair and bright, not Spring as she is at present, cold and dank with snowshowers.

\section{TO A WET SUMMER}

Welcome Summer, come at last Over seas from some far land, Where her flitting footsteps pause, Tyrants rise and bid her stand.

Wet with rain her gauzy robesHear her tell her sorry tale, How, when trying to escape,

on her flowerlike head beat hail.

Flooded streams she had to wade, Once was nearly swept away; Sank her small bare feet in snow In the field instead of hay! 


\section{"All in ye Merrie Month of May"}

Cold and weary, round her head, Wraps a rainbow, seeks to rest

In her dripping cloudy robes Somewhere on earth mother's breast,

Homeless Gipsy, wandering still, Weep for Summer, poor Sun Maid,

In the far land whence she came Surely she had better stayed.

Welcome Summer, come at last, Over seas from some far land,

Where her flitting footsteps pause, Tyrants rise and bid her stand.

The Cuckoo is a popular bird on the Border, and different birds have been known to enjoy the doubtful honour of fostering him. There are many local legends about him. $\mathrm{He}$ is one of the seven creatures thought to hybernate, and there are stories about Cuckoos flying out of hollow logs as they crackled and burnt on the fire. Some people say he then turned into a Hawk! If the first time you hear the Cuckoo you are careful to kiss your hand towards him, and then count the successive cries, you will know how many chances you have of wedding. If you have money in your pocket when you hear the Cuckoo for the first time, you will have plenty all the year to come, but ill-luck if your pocket be empty. Gay makes allusion to an old belief, which used to prevail hereabouts, that if a girl, on hearing the Cuckoo for the first time, took off her left shoe she would find in it a hair of her future husband. Just about here he is, unluckily, rather rare, as he prefers the Lammermuirs and the real uplands, which I am sorry for, as I love hearing him. In Devonshire we had so many near us! I remember, when Boy was a tiny baby newly come, I heard Cuckoos calling all around the house; so much so, I used to tell him he came from Cloudland with the April Cuckoo. The time of the Cuckoo's departure hence seems rather uncertain, but there used to be an old rhyme which declared :

In April come he will, In May he sings all day

In June he changes tune, In July may fly away; 


\section{Stray Leaves from a Border Garden}

But in August fly he must,

For a Cuckoo in September

$\mathrm{Ne}$ 'er a fool can remember.

May 28.-A lovely warm day! The white Star of Bethlehem is out, both in the kitchen-garden and in the plantation on the grass bank down where the Grosarts grow so freely.

Boy and I went to get Kingcups to-day in the fieldsWater-dragons as they are called in some places and Jonettes. There was a patch of marshy ground, thick with rushes, Kingcups and Cuckoo-flower, where a big black carthorse was roaming, making deep footprints in the mire (Icelandic, myrr). We filled Boy's little cart with black muddy roots and golden flowers and he dragged it faithfully homeward through the fields; it was somewhat difficult to hoist over the fences, but the little kilted man stuck to it manfully, for Scots never say die. There were Peewits flying all over the field. They are sometimes called Lammermuir Whaups, though I believe this name belongs more properly to the Common Curlew, also a Lammermuir bird. We were lucky enough to come upon two little ones. They run about after their mother, and if people come near them the mother flies off, trying to decoy the intruder away from the spot where the young crouch in hollows and inequalities of the ground, and hope to escape notice. We almost trod on these two before we saw them, lying curled up in the deep dry footmark of a cow, where they looked just like black furry caterpillars or hairy oubits. I took one up in my hand, a dear little long-legged " lang nebbit" creature with white and downy underside, and a sort of white ruff round its neck, and no sign of a crest as yet. Underneath it was all covered with "paddy hair," and black and chequered looking on the back, like an Arab donkey. "Paddy-hair" is an old local word which has come down from the Saxon padden hayr. It is also used for the down on little babies' heads and for boys' budding moustaches. In Fife the term is "Cat's hair." In the North of Scotland, Jamieson says the Devil is sometimes called "Auld Whaupneb," 


\section{"All in ye Merrie Month of May"}

and in Roxburghshire, near here, a person with a long nose was called Whaupnebbit. The dear little Whaup, it curled itself up quite snugly in the hollow of my hand, and looked at me fearlessly with its little bright eye, like a little black bead; I longed to take it home, but feared it would be difficult to rear, so refrained. I never heard of any one rearing a Whaup. I believe they feed on worms and insects, which are not always easily procured. We found the deserted nest some little distance away, in the same field, just a few straws with some chips of brown spotted eggshells, lying, very flattened in appearance, in a cart-rut.

Peewits are very common about here from March to October, and are very pretty birds, dark brown and white, with an elegant upstanding crest, which Burns calls green, but which looks more dark brown. This crest is said to have earned them their old name of Teuchit, from the French toquet, a little cap.

The storms which often occur in March are often called Teuchit storms, and there is a saying, "A Peesweep storm maks a fat Kirkyard," meaning the bad weather often kills off old people. I have heard that Peewit babies, if startled before they can fly, run and hide their heads like Ostriches in any handy tussock and think they are all hid. This may be their habit, but I have never seen them do anything but just squat in the inequalities of the ground, tucking their long legs away under them in the most marvellous way. They run very fast, even when tiny. They seem most to congregate in grass-fields, but I have seen the old birds circling over the brown furrows, where they look very pretty. I think they are not much beloved on the Border by the country folk, because in old days, when the fugitive Covenanters took refuge from their pursuers in the marshlands and bogs, the erratic flight of the disturbed Peeseweeps often led to the capture of the Religionists. The old Scotch term for a complaining person was a Peesweepy creature. Pliny said the sight of a Lapwing was a cure for the jaundice. I wonder if he meant just this particular bird ? There is a delightful Russian legend which says that 


\section{Stray Leaves from a Border Garden}

long ago, when God made the world, the birds were all told to carry the drops of water in their beaks to the spots appointed for lakes and rivers and seas. All obeyed except the Lapwing, who complained and declared it did not want water. So then God forbade the Lapwing to live near any stream, and its only drink is the water that collects in pools. The Russians say they cry, in consequence, "Peet, peet; water, water"; but the French explanation is "Dixhuit"; while the Scotch say they say "Peeseweep."

May 29.-Jean and I went to-day to try and get photographs of the Peewit babies. I think we must have walked about that field at least an hour before I saw at a distance some dots moving. Making a crow-line for them at once, I found my little friends. But it was very difficult to get them to pose properly. I tried to draw them lying in a hollow, all curled up together, but produced only the effect of a nest of caterpillars. Then they were too low down for the camera, and had to be installed on a high mossy stone by a tuft of grass ; finally they escaped, and we had the utmost difficulty in catching them again, as they run like lamplighters, looking most comical, like tiny Ostriches. I do hope the photos will be a success after all our exertions.*

May 30.-The Rhododendrons are beginning to show their lovely bouquets now in sundry avenues near here; with us they are a little late to flower, I suppose because they mostly grow on the north side of the house: they never seem to grow into as giant bushes here as I remember seeing in Devonshire. It is difficult, however, when one sees them apparently happy here, to realise their native home is India. The Red Daisy border is very pretty just now; I do not think I will ever be without one again. I like the Daisy, still bearing its old-time Saxon name of Dayseye, by which Chaucer loved it. In my old Herbal it is called Margret's Herb; it was dedicated to St. Margaret of Cortona. Bairnwort is a nice old North-country name for it, but I do not care much for its German name of Gänse

* They were not, the subjects were too lively. 


\section{"All in ye Merrie Month of May"}

blüme, or Goose-flower. It is odd the Dutch, Italians and Spanish should all call it Margarita, meaning Pearl. Daisyleaves boiled in asses' milk used to be thought good for consumptives. I must get some Hen and Chicken Daisies, they are so quaint ; but I think they must be gone out of fashion, one never seems to see them anywhere now. "Jackanapes on Horsebacke" they have also been called, which is also an old name for the Cowslip. In Thuringia an old cure for toothache used to be, to pluck and eat three Daisies after the tooth was taken out; this secured you against future toothache. Here the Red Daisies are "Bachelor's Button"; this name is also given to the double white and double yellow Ranunculus, while Parkinson calls the Red and White Campions "Batchelor's Buttons." I heard a charming legend the other day accounting for the presence of flowers on the earth. After Adam and Eve had been turned out of the Garden of Eden they had to work for their living hardly amid briers and brambles. They wept and lamented the lost flowers of Eden, and at last the red-winged Angel of Love was permitted to come and turn the tears they had shed, which hung on the thorns, into flowers of many colours. Waste patches of ground full of briers are called the Devil's Garden, I think, in Germany; and long ago there was prevalent a curious custom in Scotland of setting aside, by the inhabitants of many villages, a plot of land as an offering to the Devil, called the Gudeman's Croft ; it was supposed he would fly away with any bold soul who dared

To rive his croft $o^{\prime}$ the birk and brier,

Or the flowers that flourish there all the year.

May 3r.-The Crab-apple is making the lane lovely now, combined with Broom and Whin. It is sometimes called "Scrog-apple"; a "scrog" is a stunted bush, and is a very old word, I think, of Saxon origin. The German word is Hagapfel, or Hedge-apple. I found a Pheasant's nest in a furze tussock the other day with quite a number of eggs in it. It seemed so strange she should elect to sit actually on 


\section{Stray Leaves from a Border Garden}

the roadside at a corner where a stone-breaker came daily to work at a mighty heap of unpleasant-looking flints. It looks so curious to see bicycles by these stone heaps, as one so often does nowadays. Boy was missing the other day, and was at last found sitting by the hedge having a crack with this old man. Boy takes such an interest in stones, and was quite loath to part company with the stone-cracker, as he calls old Fairbairn. I heard of a keeper to-day who found a Partridge's egg and a Pheasant's in the same nest. I believe this is not very uncommon. I was told the other day of a curious use to which Partridges' claws had been put. In an old church not far from here, I hear there are some ancient altar-hangings of, I think, faded green velvet with a raised pattern of rather conventual sprays on it. In this the "stuffing" of the little sprays is over Partridges' claws. I feel I must make a pilgrimage to inspect this. In the meantime I shall ask the Cook to preserve all the Partridges' claws for me. The Thrush who built in the woodshed has reared her nestful and taken them away out into the Birdworld. What a pleasant world it must be! How pretty May is!-one of the prettiest, most delightsome months in all the year, I think. "Le joli mois de Mai, semblable à Paradis," says Gower, "car lors chantait et merle et papegai. Les champs sont verds, les herbes sont fleuries. Lors est Nature dame du pais." The plantation is quite delightful now, all alive with birds-the "new betrothèd birds" as Surrey calls them--and the fresh green leaves making a perfect tent overhead, and the white and green Woodruff a sweet carpet underfoot. In my old Herbal there is a delightful variety of name-spelling for this flower-Woodrowel, Woodroof, and Woderowe; and it is said to "chear the Heart and make a Man lightsome and pleasant." There are, I believe, still to be seen old churchwardens' accounts of the Church of St. Mary-atHill in London, in the days of Edward VI., showing that the clergy on St. Barnabas' Day were in the habit of wearing wreaths of Woodruff and Roses during the service, while the churches were decked with Woodruff, Roses, 


\section{"All in ye Merrie Month of May"}

Box, and Lavender. The birds are quite indefatigable in singing, they never seem to leave off. I wish I knew their many notes better apart. There is one bird which seems to say, "Give it her, give it her." What ? The freedom of the greenwood?

The Blackbirds are very noisy, and are such bold birds, and here are particularly well fed and portly, like bird aldermen. There is a Blackbird's nest in an old Cherry-laurel on the Primrose-bank; a scolding mama flutters out whenever we pass. Gardener calls the Merle the "terrible blackbird," because he is so destructive, a sort of avian Neso or Ivan the Terrible among crops. The Blackbird is celebrated as the Merle in old Scottish songs and ballads. $\mathrm{He}$ is also called the Ousel or Oszil. This comes from the Saxon word for the bird, which is osle. There is an old expression in Orkney " to ouze," meaning to "pour forth," so, perhaps, he gained this name from the flood of melody he pours out. An old local term for "swarthy like a blackbird" here was "ozelly." This may be the reason why, in the old Jacobite song, Prince Charlie is called "The Blackhird," from his dark complexion. The song is called "The Blackbird," and the refrain is :

Good luck to my Blackbird, wherever he be !

The following is a curious coincidence of terms, to say the least. The English spelling of Oszil was generally Ousel, and Jamieson declares that in Peebles the "Sacrament of the Lord's Supper" was called Ousel ; the old English word was Housel, and the Anglo-Saxon term for the Mass, Husl, the same as the Icelandic, while to die "unhouselled" was to die without the Sacrament. In Roxburgh, an old name for the Sacrament was "Hoozle," which was also used there to mean a band tying loose papers together; it was also used for the handle of an axe, or rather the part into which the axe was fixed. "To hoozle" in Ayrshire meant "to puzzle, to make things dark or perplex." This confusion of terms and meaning is curious. Can it be possible that it arose out of the impulse there was, after the Scottish 


\section{Stray Leaves from a Border Garden}

Church Reformation, to desecrate religious terms and belittle what before was reverenced? - as to this day, for instance, if the brose be singed, there is talk of the Pope's toe or the Bishop's foot.

There is a Squirrel's nest in the Dene, but too high up in the old Larch for me to examine it, or, indeed, distinguish much more than a mass of sticks. The nest is called a Drey in Hampshire, but has no distinctive name here that I can find.

I should like to see it close; Squirrel-babies I should fancy delightful, but perhaps they are as unlovely as most bird-babes in early youth. I know Rabbit-babies in very early blind childhood are very ugly, just like tiny Hippopotami, but they are very pretty when big enough to skip about. There is nothing prettier than to see, as I did the other day, when cycling home over Laverock Law, hosts of tiny Rabbits sitting out, enjoying the cool of the evening, on the grass by the roadside in the shadow of the Beech hedges, and at the tinkling sound of the cycle-bell scurrying off on either side through the hedge into the field where the sleepy sheep were feeding, or into the deep shadows of the firwood amongst the bracken fern. Once a very small Rabbit did not scoot across the "causey" quick enough, and he was sent flying by the cycle. It is curious how, when one is cycling, Rabbits come out of the hedge and invariably cross over just in front of the cycle, when it would seem they would be so much better hidden by just remaining in their tracks. Once I saw a small Weasel cross the road before me, closely followed, to my great surprise, by a large Rabbit! It is curious that, though Scotch people do not misplace the unhappy letter $\mathrm{H}$ as Londoners, and I believe Northamptonshire folk do, yet these Borderers sometimes insert it. I have heard it in the word "weasel," pronounced "wheasel."

A Hawk was seen the other day pursued by a Crow, and then suddenly the Hawk wheeled round and pursued the Crow. I should like to have seen it. 


\section{CHAPTER VII}

\section{A THIRSTY JUNE}

June 1.-The Primroses are still with us, a few lingerers at least, though their great beauty is over. Their place is being taken in profusion by London Pride, the well named None so Pretty, which lies like a soft pink cloud all along under the trees. There is also in abundance with it Germander Speedwell, called here Eyebright, Brighteye, and Milkmaid's Eye. I do not know if this is the same Eyebright which the Linnet is supposed to clear its eyesight with, or if it be this plant a conserve of which strengthens a dull brain. In Andrew Lang's pretty version of the old love idyll of Aucassin and Nicolete, Nicolete is said to take a herb named Eyebright, and anoint herself therewith, after having stained her fair face when in disguise as a jongleur, and then she "was as fair as ever she had been all the days of her life." The French call this flower The des Jardins, while the pretty German names are Studentenliebe and Männertreue with reference to the fleeting nature of its blossoms, also Ehrenpreis. A Devonshire name is Angel's Eyes. We went to-day to see a ruined tower on the Lammermuirs, supposed to be the original of the Castle of Avenel in Sir W. Scott's novel "The Monastery." It might well be, since the house, in a small room of which he is said to have written this novel, I saw lately near Melrose. This tower is remarkable as being the one Border peel which has a rounded corner instead of square corners, like most of the Border fastnesses. But there is not much 


\section{Stray Leaves from a Border Garden}

left of it, merely two sides indeed, and it was only tenanted by Daws and Bunnies. It stood on a little knowe with a few scroggy trees near it, and was surrounded by a mire, almost dry, which in old days was probably full of bogwater. The purple hills, scarred with brown plough-rigs, rose around, and one could easily imagine Julian Avenel's burly mosstroopers hurrying home after a successful raid in some far green valley on the "English side."

The men of the Merse were said long ago to be famed for bravery and boldness, and the women of the Merse for beauty. The word Merse is sometimes said to have come from the old Teutonic word Mersche, a marsh, and certainly some parts of the neighbourhuod are known to have been nothing but marshland. The Merse proper is said to lie between the Lammermuir hills on the north, the Tweed on the south (the English dividing-line), and Lauderdale on the west.

But, although the men of the Merse are law-abiding enough now, the innate love of fighting awakes whenever the Empire calls to arms, and Scottish regiments never lack Border men. But now the only raiders to be seen were sundry Blackheaded Grey Gulls called Pickie Maws, or sometimes Pictarnies. In "The Antiquary," Sir W. Scott calls them Pictarnies; the Farsearchers, as! Hurdis calls them, and Greycoated Pensioners. They were following the distant ploughmen and "lifting" the insects and worms turned up. They had their home over the brow of the hill beyond a great firwood, in a tiny loch surrounded by marshy ground, and nearly choked by reeds and rushes, called the Pickie Moss, or Mire, where we saw their nests, like untidy bundles of straw, floating out of reach in the very centre of the bog. A widespread tradition calls Gulls the souls of shipwrecked seamen, and says they cannot stay long away from the sea. True it is that, like the Vikings of old, the Pictarnies at times completely disappear from their inland rests and wing their way back to the sea. In September and October the myr is deserted, we are told, not a grey feather to be seen. But since the I68 


\section{A Thirsty June}

souls of lost mariners are said to become seabirds, it is perhaps no wonder they want to smell the sea sometimes. Unsteady younglings, however, were now trembling about on the rushes at the edge of the quagmire, while the agitated parents in hundreds filled the air above, looking like a veritable snowcloud, or Mother Hulda plucking her Yuletide geese. The noise they made was indescribable, like hundreds of penny rattles all going at once, or sharpening of saws. It has earned them the name of the Laughing Gull, which is, I think, a very poetic way of describing their intolerable din. I believe this haunt of the Blackheaded Gull is about the only one left in the district, since they were driven away from the Castle Loch by the expedient of lighting fires on the little islets they frequented, the owner, it is said, disliking the noise they made. Other "mosses" they liked have been drained. They have deserted a place just over the Border, in Northumberland, rather to the vexation of the owner, as their flitting is regarded as an evil omen. There is a similar superstition about Crows, as Rooks are popularly called hereabouts, and it is alleged the Crows all departed hence just before the burning of our poor little mansion-house. Certain it is there are none nestling here now, though they pass over the place morning and evening cawing. Virgil and Chaucer both say, if Crows caw much and hoarsely, it is a sign of rain. Does this apply to Rooks, I wonder ?

June 3.-The Woodroof is out in abundance, along with Bluebells and Ferns. I think it is in Germany the Woodroof is put with white wine with slices of peaches and the liquor drunk under the name of Maitrank. I am very busy picking it to-day. In muslin bags it is delicious for putting amongst linen, having an indescribable sweet scent rather like hay. Sweetgrass is a nice old Border name for it. In Johnston's curious old book on the Eastern Borders he says people liked to have a flower " neatly dried laid in the case of their watch." In one of Miss Wilkins' New England stories, she mentions baskets made of Sweetgrass. I wonder if this would be our Woodroof? It is curious 


\section{Stray Leaves from a Border Garden}

that the fern Polytrichum commune, called here Hairmoss, or Great Golden Maidenhair, also had the name of Laverock's Lint. Laverock, by-the-way, is real old Anglo-Saxon for Lark. In Orkney, a quaint name for the Lark is Our Lady's Hen ; somewhere else it was called Heaven's Hen.

I saw some Butterflies to-day, White and Red Admiral, I think, but I am not learned in Butterflies, though I love them. I remember as a child being taught to mount Butterflies by drawing the bodies and antennæ with a fine pen or brush, and then sticking the butterfly's wings flat on the paper. I have heard that, if you want Butterflies in abundance, you should cherish Nettles-or rather, since they need no encouragement, leave them undisturbed-so many species feed on them, especially Vanessa urticaria. They are certainly fond of Giant Sunflowers; some one told me they saw a Sunflower Disk quite covered with Red Admirals. But not here; on the West Coast, which to us dwellers on the East Coast is the Land of Envy, for the mildness which coaxes forth the flowers and allows Fuchsias to grow into trees and palms and gum-trees to grow out of doors. Sunflowers do not seem to be a generally popular flower or to grow very freely here, not as they do in East Anglia, where none of the little gardens round the thatched cottages ever seem to be without a row of splendid Sunflowers. The Sunflower is sometimes called St. Barthelemy's Star, I suppose because it flowers about his day.

There is a story of an ancient Border dame whose ideal of ornamental gardening was to fill the parterre in front of her great mansion with a regiment of Sunflowers. This fancy earned her the local character of a great gardener!

James Montgomery, whose poems are now, I think, unduly neglected, has written very pretty verse in praise of the Sunflower, but it is not a flower taken much notice of by poets in general apparently. Yet I have always liked Sunflowers ever since I read Mrs. Ewing's pretty little child's story of the Rushlights and the Sunflowers.

There is a Chaffinch's nest with several eggs in it hidden in the Rhododendrons near the Thrush's nest. 


\section{A Thirsty June}

It is in Wiltshire, I think, the Chaffinch is sometimes called the Chink, a dear little name, which seems so suited to his here-and-there liveliness. Madam Thrush's young ones are nearly fledged, and look prettier than they did at first discovery. In Sir Walter Scott's " Minstrelsy of the Border," in the old garden where the Queen of Elfland takes True Thomas the Rhymer, they meet with the Throstly Cock. The name Throstle probably comes from the German Drossel. The Dog-rose in the "plantin" is beginning to show its purple flowers. It is thornless, and loves growing under trees-even under Beech-trees, where, as a rule, no plants seem to like living, a pleasing and rare peculiarity.

I have only once seen a similar Rose, in a neighbouring garden, and such a big bush! It must be very old. But it seemed to me that that bush partook more of the character of a Sweetbriar. My Rose has curiously long red narrow heps. The Columbines are out now (Columbos, as the old Scotch poets call them). I have abundance of old-fashioned kinds-black, dark purple, crimson and white, with small turbanlike flowers, besides a few long-spurred white and cream-coloured ones. In my old Queen Anne Herbal there is a quaint picture of a Double Columbine, just like what has grown in this garden for years. I must get some of the scarlet and yellow foreign kinds. William C. Bryant sings the praises of Columbines, but, as a rule, the poets seem to have neglected them.

The big white scented Iris Florentine, I think it is called - La Flambe Blanche-is out too, and is so beautiful I do not wonder it was one of the many flowers dedicated long ago to the Virgin Mary. "Italian Flower de Luce" is the old Herbalist's name for it, and "Florentine Orrice." Among other good qualities ascribed to it by old "poticaries," it is a remedy administered in a potion against laziness, wherefore all good housewives should make a point, methinks, of growing it in their gardens for the benefit of their household.

As it grows easily here, I rather wonder some enter- 


\section{Stray Leaves from a Border Garden}

prising Scotch gardener does not plant a lot of it and sell the roots to the perfumers for orris root. The Florentines are said to make a good thing out of it, and I believe it is rising in price every day at Florence, as the amount grown is limited, and the demand for it grows daily. Certainly it is a delightful perfume.

I have planted the Gladwin Iris down by the river where the Yellow-flags grow-the Myrtle-grass of the old Herbals-and I hope I shall have a large crop of its pretty seed-vessels for winter decoration. Its root is said to be a cure for the King's Evil. It was sometimes called Roast Beef-flower, from its smell. The bed of Sweet Nancies, or Narcissus Poetica in the Lily-garden is a perfect sight, and fills the air with perfume, while the Columbines in the border round it will soon be looking lovely; they come into bloom later than elsewhere, because they are so overshaded by the Beech-trees of the plantation. How I love Ladybirds, the Bête $d u$ Bon Dieu as they are so prettily called in France! Lady Landers is an old Scotch name for them, as dedicated to Our Lady. In the West of Scotland they were called Clockleddies. In Sweden, Klock-a means an earwig. Perhaps this has something to do with it. In this part of the world there used to be an old rhyme:

King King Coll awa',

Tak' up yer wings and flee awa'.

Ladycow and Bishop Burnabee were other old names. And then there is the old song:

Ladybird, Ladybird, fly away home,

Your house is on fire, your children all gone,

All but one, and her name is Ann,

And she's hid under the pudding-pan.

I tell Boy to say this, and the Ladybird generally departs before we come to the end. The Apple-trees are in pink and white glory, and the Plums and Pears are lovely. June 6.- My French Columbines are now in flower. Ancolie is such a dull name for them; they should have 


\section{A Thirsty June}

been Belles de Jour, as Marvel of Peru is Belle de Nuit. I call them French Columbines, because I collected the seed in a dear little old terraced French garden, where they grew in semi-wild profusion along with Scarlet Flax. There were hedges of Lavender, and Roses, and Aloes, and Medlar-trees there, which made white bouquets of bloom, by the square tank full of water, and the garden melted away into a wild hillside thick with Myrtle and Rosemary, Lentisk, stunted Firs and Ilex. Along the fringe of the woodland grew purple Star Anemones and tiny little Arums or Friars' Cowles. . . . But, alas! that garden, like so many others, has since suffered from a desire to improve on the part of the present owners. "You cannot paint the Lily" is not sufficiently borne in mind nowadays, I think.

June 7.--How pretty the kitchen-garden is just now, with its Red Peonies, or Pionies, as old people here call them, and white and blue Centaurys! This pronunciation still lingers in America. I really must get the salmon-pink Centaury, which grows in the Castle garden. I have heard that in Sussex the village mothers, when their babies are teething, used to make them wear necklets of beads turned from the Peony-root as a preventive of convulsions. A bit of the root hung round a child's neck was formerly deemed a cure for epileptic fits, and also sovereign against nightmare, and, according to Mathiolus, a powder of the seeds would restore speech to such as had lost it. The Peony was called the Flower of Wealth by the Chinese. There is also in the garden red Geum, like glowing scarlet Rosettes, some Monkshood (but the glory of the old Helmet-flower is not yet at its zenith), and some Lily of the Valley, the May-lilies of some of the old Herbalists. We have only a small bed of this delightful flower; I wish we had more. But, apparently, the ancestor, who loved bulbs, did not care about May-lilies. I wonder he did not, as it is said to be a cure for the gout, an ailment the hard-drinking gentlemen of the last century seem to have suffered from in no small degree. The German name is so pretty-Maiglöckchèn (Little Bells of May). The French name, Muguet, is rather 


\section{Stray Leaves from a Border Garden}

quaint; it used to mean "Little Dandy." In old Herbals they are sometimes called Muggets, and the Italian name is, I think, Mughetto. Some of the old superstitions connected with May-lily are very quaint. I like the idea that a decoction of it distilled in wine is a cure for a bad memory. Surely a bottle of this would be a nice present for many of one's friends and neighbours, and should certainly be on one's own toilet-table. There seem to be some places still in England where it grows wild. Boy's nurse talks of a wood, I think, near Lancaster, where she went to gather May-lilies. And I believe, in the Sandringham woods, pseudo-wild Lilies of the Valley are cherished; and I know of a wonderful modern Flower Wizard in that neighbourhood who is able so to retard the blossoming of Lilies of the Valley by artful refrigeration that we may, if we please, enjoy them in bloom all the year round! (Messrs. Jannoch, King's Lynn, Dersingham.)

June 6.-I heard a Nightjar this evening, after dinner, "churring" or "purring" away in the ivy-covered Beech, the first time this year. I do not think they are very common in this neighbourhood, though I believe they have been sometimes seen about the Lammermoors. Gilbert White calls it the Churn Owl, another name is the Fern Owl. It is sometimes also called Goatsucker, Puckeridge, and Dorhawk.

June 7.-I was awake last night about 2 o'clock, and it was comparatively light ; there were actually birds singing, while an Owl was hooting weirdly; I suppose the Brown Beech Owl, who lives in the old beech near my window. I fancy our ancestors rather liked Owls, since in old Barns there are sometimes found what are called "owl-holes," places made especially for the Owls to get in to the barns ; stone perches even were sometimes provided. I believe they are rather maligned birds, and it is a pity gamekeepers dislike them so much. I think it is cruel to keep Owls in captivity. I saw one once in a small box; he looked such a melancholy captive and yet so dignified, a sort of owlish Napoleon. The young Thrushes have flown; 


\section{A Thirsty June}

the nest was empty to-day when I passed by and took the usual peep.

June 9.-The Yellow Asphodelline-King's Spear is the old name-is in great beauty just now ; its golden spires are so effective in the border, but not much worth cutting for the house. It does not seem common in other gardens round about-at least I have not seen it. Great Valerian or Spurflower is out now in the old quarry, and looks very pretty mixed with Burdock. I never see Burdock without thinking of Andersen's delightful story of the little Black Snails who lived under the Burdocks, and were served up on silver dishes. I wonder if Andersen meant Butter-burs by-the-way, not Burdocks? I have never seen people eating snails here, though in Devonshire I have seen people picking snails out of old walls and eating them like periwinkles, as they do in France: and I used to delight in an old story about a mother, during the Irish famine, who was haled before the sheriff accused of witchcraft because her children looked healthy when others were dwindling for want of food, and who confessed at last that the food in a mysterious barrel was just Snails! In France it used to be a common sight during the vintage to see the grape-pickers, while they plucked the bunches of grapes, picking snails at the same time into the big pockets of their wide blue aprons. Pâte d'escargot is deemed good for consumptive people. I well remember as a child noticing the round boxes of this medicine in the French chemists' shops, with the picture of a snail on the outside. Snail broth used, I believe, to be an old English South-country cure for consumption; while in the North country a gruesome cure for warts used to be hanging a snail on a thorn, and as the poor thing wasted away so would the warts depart. That picturesque old Jesuit, Rapin, in his garden poem, says that when Rhodanthe was changed into a Rose by Apollo her lovers were changed into Butterflies and Snails. The Devonshire name for a Slug was a "Dewsnail." Apparently, our common Black Slug is not an inhabitant of America, since I once found some Americans marvelling at his queer appearance, and 


\section{Stray Leaves from a Border Garden}

still more so when they were told he carried his shell inside instead of out. In the garden now both Red and White Valerian is coming on, and a plant of the pale pink variety, which grows wild in the South of France, and also freely on railway cuttings and old walls near Dawlish, Dartmouth and Torquay. Catslove is a nice name for it. It is an old belief that cats love eating the root. The Red Valerian is called "Red Lightning" in some places. William Allen Richardson, Prince of Roses, is showing two or three lovely auburn buds, and there are some pink Monthly Roses out now. The Waterside Croft is full of Purple Meadoworchis and delicious Pink Clover. The Humble-bees are about, full of noisy fuss. It is odd that the Scotch word Bumbee should be so like the Italian Bombare, a humblebee. The nest is called a "bumbeebyke" ; and to " bum " means to "buzz." Burns writes of a "Bum-clock," meaning a humming-beetle; and a Ladybird is called in some places a "Clock-leddy. There is also an old Scotch word, Bumbard, meaning "lazy." A blundering fellow used to be called "a Bummeler," and certarnly, a Humble-bee does look a very blundering fellow as he goes bummeling about. At the far end of the croft, where I was to-day, the Laburnums tapestried the cliff, and did look so pretty!

An old Scotch name for the Laburnum was the Pea-tree, and an English one, Gold Chains. They grow particularly well hereabouts; there is one road which is quite an avenue of them. A flower I brought from Auvergne is now looking lovely-Achillea millefolium, I think, is its name; its cloud of tiny dainty white flowerets reminds me of London Pride. The yellow Iceland Poppies and big red Oriental Poppies are beginning to come out. I think there is nothing lovelier than a bed of white and orange "Icelanders" with the sun on them, or a bed of pink and white Shirley Poppies-Himalayan Poppies some people call them. They are splendid for table decoration, in spite of their frail and ethereal appearance. There ought to be a fairy tale attached to Poppies. Common Poppies were used as love-charms long ago, and a cataplasm of PoppyI76 


\section{A Thirsty June}

heads applied "to the Crown of the Head (being first shaved), is said to be profitable against Dotage!" The Poppy was one of the flowers sacred to Venus; they were also supposed-at least the Red Poppies-to have sprung from the drops of the blood of the Dragon slain by Saint Margaret. A nice name for the White Poppy in German is Schlaf bringender.

Cop Rose, meaning "red button," was an old Anglo-Saxon name for the Red Field Poppy. How pretty the Nigellas are!-Katherine-flowers, so called because they resemble the spokes of St. Catherine's wheel. And saith my old Herbal, "The Fumes from this Herb being burnt drives away Flies, Gnats and Musketoes out of the Room in which it is used in Summertime." Fennel-flowers they used also to be called, Love in a Mist, Love in a Puzzle, Bishopwort, and Devil in a Bush, the last because of their horned seeds. They grow wild in the loveliest profusion on the hillsides on the Riviera, all shades of blue, and pure white, looking like china flowerets. I saw some the other day looking very pretty as a thick border on each side of a garden-path. They never seem to grow very large flowers, however, here.

June II.-The Water-hen has taken her young family away down the river. A few days ago we paid her a visit, peeping over the field-paling at her chicks tumbling about among the small branches of the decayed Larch bough which masked her nest-such beloved little dark soft-looking balls with reddish beaks! She was not at home, we saw her walking afar off in the grass. To-day they were all gone, save one solitary egg, which, I suppose, is addled. I found a dead Hedgehog yesterday. I have not seen one dead or alive for a long time; either they are rare, or else the gamekeepers kill them, as they bear a bad character in regard to eggs. An old Scotch name for the Hedgepig is "herison," probably from the French hêrisson. In Italy his resemblance to a Chestnut-burr (Riccio) has earned him the name of Riccio spinoso. In German he is the Igel, and in Spanish Erizo. 


\section{Stray Leaves from a Border Garden}

June 13.-The Holly-trees are all covered with their dear little white flowers. There is an amusing local saying about an inveterate liar! " $\mathrm{He}$ only lees when the hollens are green." We are suffering a good deal just now from drought this last week or ten days; the flowers are hanging their heads and wilting. The Sweet Nancies are all over and the Rush Iris are small and puny looking. My Roses in the Rose-garden are covered with buds, but, alas! also with orange-coloured blight. I picked some lovely Moss-roses to-day and some commoner pink Monthly Roses. China-roses is a prettier name for them, I think ; they always look as if made of china. I love Roses, and it seems difficult to believe in people disliking to see a Rose, even in a painting, as is recorded, I believe, of Catherine de Medicis, while Cardinal de Guise was said to faint if he smelt a Rose.

I like the German

\section{LEGEND OF THE MOSS-ROSE}

Under a rosebush asleep one day,

Behold the Angel of the Flowers lay,

He to whom Heaven hath given command

To care for all flowers throughout the land ;

He was aweary with the summer's heat,

Under the Rose-tree the shade was sweet.

After enjoying this sweet repose,

The grateful Angel said to the Rose :

"What gift, O Rose, can I give to thee

In return for the shelter thou gavest me ?"

Hanging her head with blushing glow,

The Queen of the Flowers murmured low :

"I would thank thee for another grace."

The Angel paused with thoughtful face ;

What charm was there the Rose had not,

What could he add to her peerless lot ?

Then looked where he had lain to rest

On moss as soft as mother's breast,

And a veil of moss he lightly throws

O'er the blushing beauty of the Rose!

Our Gloire de Dijon Rose is rather backward this year,

I have seen other trees in bloom elsewhere a week ago. I 78 


\section{A Thirsty June}

The yellow Daylilies are struggling up, but they seem to find the sun rather hot for them. Yellow Lilies are delightfully called Gold Lilien in Germany.

June 14.-The double pink Rose Campion, "Rose of Heaven," is looking so pretty now ; truly "Gardener's delight!" The double white one is like a small Carnation. I love all Campions, from the wild wayside pink and white ones to the tiny white-flowered one which grows on the seaside cliffs. "Plum-pudding flower" it is called somewhere, I forget where. I am trying yellow Verbascums, or Mulleins, as pot-plants, or rather as standards, by the entrance door. I think they will look rather handsome with their grey velvet leaves and Aloe-like spires. But it may be they will look too plebeian. They are also called Hag-tapers, or Hedge-candles and Witches'-candlesticks and High-tapers, very appropriate names for their tall yellow-flowered columns. I believe this name came from an old custom of dipping the dry flower-stems in tallow and using them as links. They were also called High Aloes; the German name was König Kerz. The muchpruned Laurels in the undergrowth are sprouting vigorously. Our great grey Tom will no longer be seen skulking in the underwood seeking what he may devour of rabbit or bird. The fiat went forth yesterday: Death or banishment. So he was caught when he came indoors to take an innocent nap, and forthwith packed in a basket and despatched by train away to the great city, to keep a friend free from mice and such small deer. Nemesis overtakes all, even cats. No doubt the birds are now rejoicing; the usual inquisitive Robin-I never did know such curious birds ! was looking on from the Holly-tree as Puss was carted away, proclaiming the injustice of his sentence at the top of his voice. I am sure Robin Red has carried the news abroad, there was such a chattering of birds in the Hollyhedge this evening.

Boy paddled to-day, to his intense joy, in the river, grown very shallow, and actually he and some little comrades caught with a jar a Minnow! They looked so comical, all 


\section{Stray Leaves from a Border Garden}

hopping about, half in and half out of the water, from stone to stone, balancing themselves like little "dippers," or sailing "fairy boats" of flower-petals. One little fellow, with sunbleached pow and merry little brown face, nearly as brown as his rather elementary garments, looked just like a water-baby; I almost expected to see him sail away on one of the big Butterbur-leaves he was setting afloat with shrill squeals of delight; while a sweet little curly-haired lassie, holding up her little red petticoat with one dimpled hand, was quite a Birket Foster picture, as she set sailing on leaf-boats, flower fairies of Crowfoot flowers, Daisies, or purple Vetchling. There was quite a forest of big Butterburleaves along the bank, and the bairnies plucked them and waved them proudly as parasols, and then cast them into the water to sail down the stream. The Spanish name is Sombrera. Under the Beech-hedge there were still red and white Archangels or Dead Nettles in bloom, called "Our Lady's Hands " in France, and large Docks-Dockens, the children call them, saying, "In Docken, out Nettle," when they chance to get stung by the "stingy" nettles, an old charm alluded to by Chaucer.

In Wiltshire the saying used to be

Out 'ettle in dock,
Dock shall ha' a new smock,
Ettle zhant ha' nanum.

June I4.-Boy went out to-day armed with a green gauze Butterfly-net, with which he intended indifferently to catch Butterflies and Minnows! He looked so quaint in his loose blue blouse with his golden head and bare feet ! he will not wear stockings in hot weather. He reminds me of the Scratlings said to haunt the depths of the Norway forests, especially in winter, when he wears a red Tam o' Shanter cap, and looks like a little red mushroom on the bank, when he squats in the snow. 


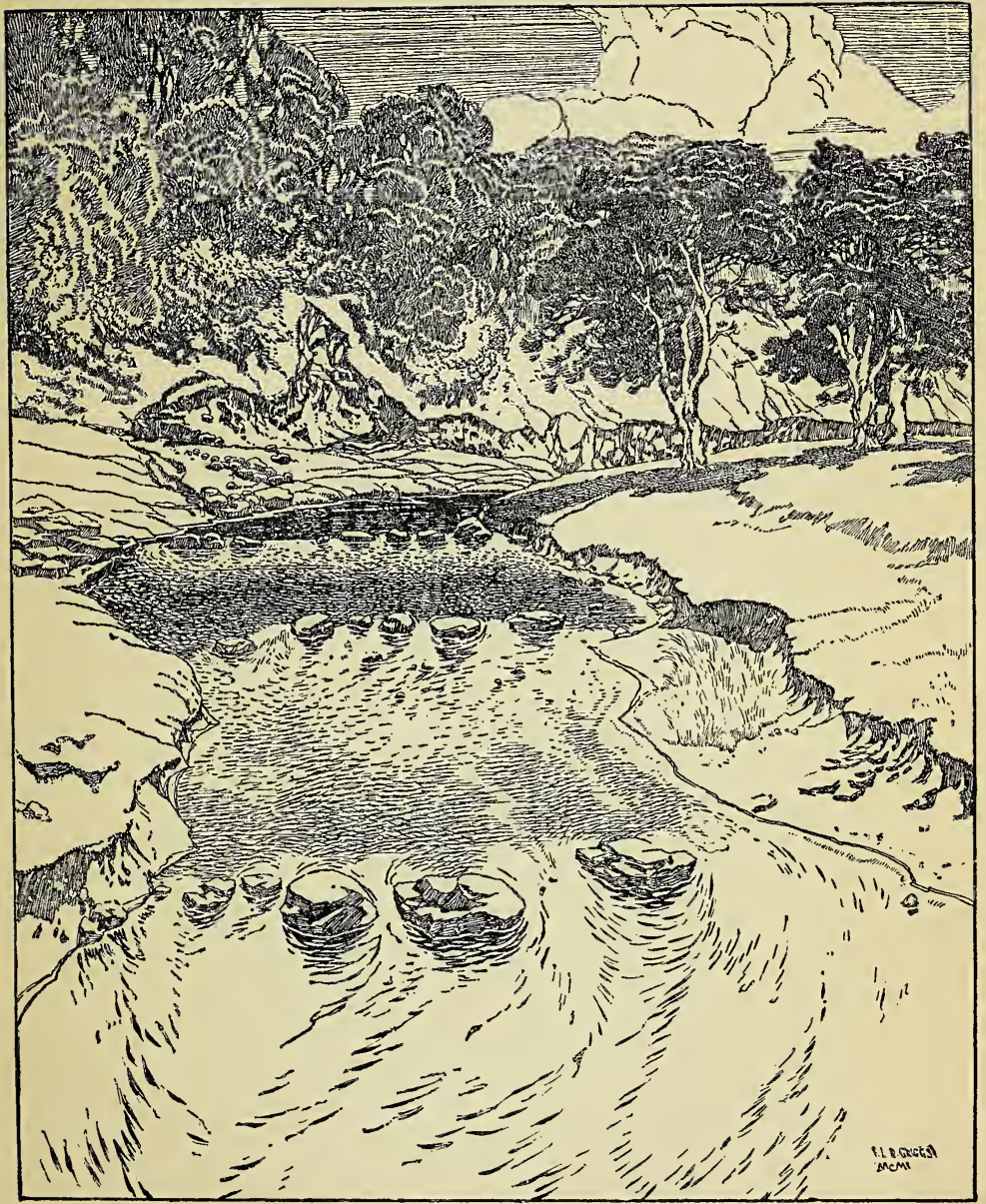

The Blackadder, from the Footbridge. 



\section{A Thirsty June}

\section{SONG OF THE SCRATLING}

Oh! where and oh where do the Scratlings live,

Where and oh where do the little Scrats live?

Scrat lives in a cave tucked under a hill,

He comes out at night when all is still,

He runneth about in the lush green grass,

O say, have you seen a little Scrat pass?

A little red pointed cap he wears,

For nothing on earth or sky he cares,

He sings a little weird birdlike song,

As he right merrily skips along.

He chaseth the owls as they fly by night,

He plays about in the white moonlight,

It shines on his curly golden hair

And little brown feet for ever bare.

He sings the little Bunnies to sleep,

He helps the Fairies night-watch to keep

As they dance by night on the dewy grass,

O say, have you seen a little Scrat pass?

He feeds deserted birds in the nest,

He rocks the rooks to their airy rest,

He robs the bag of the Bumble-bee,

O say, did you ever a little Scrat see?

Whenever the winter wind doth blow,

And drifting comes the weary snow,

The little Scrat skippeth out to play.

By field and forest and lone highway,

You may see afar off something red-

That's the cap on his bonny head,

And a laugh like a far-away sheep's bell

Betrays a Scratling by moor or fell.

Iune I6.-I saw a Guelder Rose-tree with pale pink flowers the other day; it was curious, but I do not think as pretty as the old white kind, which last grows wild in some parts of the Merse. Snowball-tree it is called here ; "Tistytosty" is a rather nice Wiltshire name; and Rose-Elder was an old Herbalist name for it. The Elder in Sweetbriar Lane is full of flower. I pick great bunches of it to put in my water-jug, and in the bath it makes the water delicious and soft. In some countries it is said one should take refuge under an Elder in a thunderstorm, as the Cross was made of Elderwood, and therefore the fire of heaven will not strike it. Luckily we do not have many thunderstorms here, though I remember one curious 


\section{Stray Leaves from a Border Garden}

instance when I heard thunder and saw snow at the same time. A Danish cure for toothache is to put an Eldertwig in the mouth and then poke it into a wall, saying, "Depart, evil spirit." I think it was in a copy of Andersen's "Fairy Tales" I once saw a gruesome picture of the Spirit Toothache, gaunt and thin and white, like a clawfingered skeleton.

June 1 7.-Still very hot. The pink Pyrethrums are all out, and look so pretty ; also the French turban Ranunculus, like the daintiest and freshest cream-coloured rosettes. The lane I call Sweetbriar Lane I sometimes think I must rechristen May Lane, it is so gorgeous with sweet white bloom. Gawin Douglas, the delightful old Bishop of Dunkeld, in his too little known lovely description of May, says, "the bloomèd Hawthorn clad his pykis all." The Greeks had a pretty fashion of decking the altars at weddings with Hawthorn-blossoms, and the bride generally wore a wreath of Hawthorn. I remember being told it was unlucky to bring May into the house- - Bring May in, bring Death in "; another reason against it urged to me was, that out of a house whereto Hawthorn-bloom is brought no daughters will be asked to go. This last superstition also clings to Peacocks' feathers. In India it is thought very unlucky to bring them into the house at all, yet I love them, and have great bunches of them.

June 1 9.-It is twenty-six days to-day since we have had a drop of rain - the longest successive period of drought for fifty-four years, except in the year 1869, when it was twentynine days. The farmers are all lamenting they have had to sow Turnips three and four times over, and the fruit-blossom is all dropping off. This evening we heard faintly across the little river the sound of a violin and concertina, evidently labourers dancing reels at the far-off farmsteading. It sounded so pretty in the evening quiet!

June 20.- Between 2 and 3 o'clock this morning a Thrush was singing beautifully in a far-away, sweet trilling voice, but in the extreme stillness of the night I heard every note that the "throstly cock" sang. With the waking I82 


\section{A Thirsty June}

of the workaday world came the welcome sound of raindrops, and we have had showers all day and a heavy mist. I never thought to be so glad to see rain in Scotland. Just a little more of this rain and we shall have an abundance of flowers and vegetables. In our late straits I ventured to broach the idea of Nettles to the Cook. To my surprise she met me halfway, and willingly consented to cook them, saying she well remembered in her young days in Dumfriesshire how the earliest Nettle-sprouts were used both in soup and as a vegetable prepared like Spinach, and equally good she averred. The well-grown Nettles were given to the cows, who were passionately fond of them. It was thought the flavour of the milk and butter was improved by this diet. Here is an old recipe for Nettle-beer. I think some day I shall try it, though our Nettle-broth was, unfortunately, rather tasteless, owing to the Nettles being too far advanced. Nettle Beer: Take one gallon of spring water, boil in it 2 quarts young nettle sprouts. Strain the liquor. Put to it $\frac{1}{2} \mathrm{lb}$. sugar and $\mathrm{I}$ teaspoonful ginger. When nearly cold, ferment with yeast and bottle securely while in a state of effervescence. It will be ready for use in a few days. Nettle-tea is an old remedy for nettlerash. In an old family receipt-book, over two hundred years old, I have the following recipe for a Syrup of Nettles: "Pick the youngest Nettles in April, and put them in a Pintstoup; put the Stoup in a Pot of Water, and let them simmer for twelve Hours, then squeeze out the Tincture and put it in a clean Pan, break the Whites of two Eggs and mix with it ; and when it boils skim it, and to every Mutchkin of Tincture put a Pound of brown Sugar-candy. When it is dis. solved, set it on the Fire and boil it up to a Syrup, then let it cool, and bottle it ; put no Water to the Nettles. They are good for Consumptions." One never hears now of Nettles being used to make linen, and yet they were long ago, since Thomas Campbell, the poet, writes of sleeping in Nettle-sheets and using a Nettle-tablecloth; and in Andersen's delightful story of "The Wild Swans," the king's daughter wove the Nettles into shirts for her brothers, 


\section{Stray Leaves from a Border Garden}

changed into swans. In Ireland, I believe, the Nettle is called the "Devil's Apron." An ill-tempered, peevish person was formerly called in Scotland "netterie" or " nettlie," and to be in " nettle earnest" meant not to be trifled with. In my old Herbal the virtues ascribed to Nettles are such I feel quite ashamed of the war we have raged against the Nettles which had overrun this place when we first came. In an essence they are good against the "Stinging or Biting of any venomous Creature, as of Serpents, Mad Dogs, Scorpions, Hornets, etc., and Resists the Poisonous qualities of Hemlock, Henbane, Mandrake, Mushromes, Nightshade, etc. Bathed upon overwearied Members, it refreshes them, eases Pains and Discusses simple Contusions. The oil by Decoction, made of the Juice or Green Herb bruised and boiled to crispness in Sallet oil and then prest forth, reiterating the operation three times. Being anointed upon a place stung with Nettles, it is said to be a perfect Remedy, to take away the pain and stinging. A Cataplasm made with equal parts of Green Leaves of Nettles, and Dwarf Elder Leaves, and applyed to the Gout, Sciatica, or Joint aches in any part, it quickly gives admirable ease, and in a little time Cure." This last modest assertion is quite delightful. Further, "the Pouder of the Leaves and Seed given to Hens in their Meat in Winter time is said to make them to lay Eggs all Winter more plentifully." This last assertion was received with polite incredulity by a hen-wife to whom I quoted it. An old Scotch rhyme says the Nettle must be pulled in June :

Ere it's in the blume

Pull it by the auld wa's,

Pull whar the sun n'er fa's,

Stoo it when the day daw's,

$\mathrm{Pu}$ ' the nettle early.

Ang.-Sax. netel; Danish, naelde; Swed. noetta; Ger. nessel. Till flax and hemp came into common use, the Nettle seems to have supplied all thread for weaving.

I was amused to find the other day that in the Gardener's I 84 


\section{A Thirsty June}

eye there is evidently an aristocracy of vegetables as there is of flowers. In the absence of the early Spring Onion the despairing Cook breathed the word Chives. But on applying to the artist in gardening: "Oh! Chives have never been in this garden yet. Ou ay, I ken it weel ; ye'll find it in all the hinds' gardens, but no in the Laird's. There's some Cooks wadna demean theirsels to cook them for the likes of you. They're just a common vegetable, common, common, no aristocraticlike. But I'll gie them a corner if ye wish." So little common Chives, the poor man's comfort, is to rub shoulders with Lady "Lettice" and Lord "Spinage."

June $2 \mathrm{I}$.- A Tree-creeper was observed to-day progressing in its curious circular way round an Oak-tree. They are not very common here, but have been sometimes seen. There seems to be a Tree-creeper's nest in a low tree near this Oak-tree, but it is now empty. I wish I had found it when it was tenanted. It looks like an untidy bunch of Oak-leaves and open at the side instead of the top. It rained again to-day, but cleared in the afternoon. Some of the flowers are a little cast down, but in the main the garden looks refreshed. The White Bride Gladiolus are in great beauty, also the white and lilac Dames Violets or Rockets-Night Violets as the Germans so delightfully call them. There is an old-fashioned double Rocket I must try and get ; it used to be common in old Scotch gardens. Rockets make the most lovely beaupot, helped with a little pink Ivy geranium. The Yellow-flag Iris down by the river is in full bloom, and looks beautiful in a big bunch in a blue bowl. This Yellow-flag grows in great patches on the Isle of Iona, and it is very pretty to see the masses of yellow and green glory on the island shores from the decks of the summer steamers, with the long-horned furry Highland cattle standing knee-deep in it.

In the garden I have a Yellow-flag with lovely green-andwhite-striped leaves like an old-fashioned gauze ribbon, somewhat like the Ribbon-grass our grandmothers called Gardener's Garters or Mary's Garters, or, more prettily, 


\section{Stray Leaves from a Border Garden}

Canary-grass and Our Lady's Garters. This last I cherish on one of my rockeries. I saw it once grown as a pathedging; it looked very pretty. I do not remember where I got the striped Iris, but it is a treasure. Well, well, "More grows in the garden than the gardener sows," says the old Spanish proverb.

June 22.-The Syringa is beginning to come out. In a few days it will scent the whole place, so many old bushes grow here. There is a story that long ago, when the house was let, the tenants objected to the smell as being too strong. Can one have too much of a good thing ? Syringal the Gardener calls it; a delightful name. One thinks of Joringel, in Grimm's Fairy Tale, putting it in his flat cap as he goes in search of his bride. Mock Orange is another name for it. I know of a very small variety which is extremely pretty; I must get it. A charming yellow Turk'scap Lily, or Martagon, is out now, yellow turned up with green, stamens orange, most objectionable surely to witches, since they are said not to like either green or yellow. It is despised as common and old-fashioned hereabouts, but I have never seen it anywhere else, except at Fort William, where it seemed to be common. It has a strong scent, somewhat recalling Honeysuckle. This is probably the one called in Germany Goldwurz. Here I have also a vivid scarlet Turk's-cap (Pomponium verum), very pretty, the Lily Pompony of the old Herbal, I think, and a dark magenta one, more curious than pretty, which I have seen growing wild in Auvergne. Wallace, of Colchester, the famous Lily King, has published a most interesting little book all about Lilies, which should be in every bookcase.

The result of perusal is to make one long to give him an unlimited order for the many bewitching varieties. In the garden there is a pale pink Turncap with tiny dark specks all over it, which has, curiously enough, always borne here the name of Crown Imperial. There do not seem to be here any real Fritillaria Imperialis-the Crown Imperials of Parkinson. I must get some; no garden is complete without their beautiful stateliness, to my thinking. There was I 86 


\section{A Thirsty June}

an old belief Red Lilies were sacred to Trolls and Woodwomen; and in Spain and Germany it was said that the Red Martagon Lily-Herb of Mars-gathered with prayer, had the power of dispelling enchantment. Red Lilies were the badge of the Guelph, and White Lilies have been called Mary Lilies, after the Virgin, for many a long day.

I was very busy to-day training and trimming a hedge I have planted of Sweetbriar, Syringa and Roses ; it bids fair to be "very agreeable to both sight and smell," as somebody says. I am meditating a hedge of China-roses and Pyrus Japonica, called Fairy-fire, I think, in Ireland. The idea is not original, I must confess. During that oasis of peace in the uneasy life of the great Irish patriot, Lord Edward Fitzgerald, when he lived at Frascati, so pleasantly described in Moore's Life of him, as re-edited so sympathetically by Mr. MacDermott, when Lord Edward took his ease making a garden, among the pleasant plans he laid, with the little wife he loved, was a hedge of China-roses, mixed with Pyrus Japonica. Prince de Ligny, I think it was, who said plotting was incompatible with gardening.

I have heard that a pleasant conserve can be made of Pyrus Japonica fruit, but I have never met with it, or with any one who has tasted it. The purple Rhododendron is in great abundance and beauty just now, but $I$ wish we had the crimson kind; I so much prefer it. The Strawberries are beginning slowly to ripen ; one or two have already been "sampled." Strawberry is such an odd name; I wonder if it really does come from the Saxon word Streow berie, meaning "stray," because the runners stray so far? Another explanation is because straw is put under the berries to prevent them getting muddy. The different varieties have sometimes very quaint names ; I like particularly Strawberry Fillbasket. But in vain have I wandered up and down by the Strawberry-bed when the leaves have been dying, to try and smell the "most Excellent Cordiall Smell" which Bacon declares they have. It is a plant of great antiquity. Virgil and Ovid knew and delighted in it. According to my old Herbal it has many virtues, one of which is, it is said to 187 


\section{Stray Leaves from a Border Garden}

make loose teeth firm if the juice mixed with Mutton-broth be used as a Gargle! As for the "Ripe Berries, they refresh weak and Fainting Spirits." Some people eat Pepper with Strawberries ; this is said to be practised both by Mexicans and Scotch! Our American cousins have a recipe for a most attractive dainty, Strawberry Short Cake, which I must try. The dish is of New England origin, but the recipe sent me comes from Virginia. This is it. Strawberry Shortcake: Take I quart flour; I teaspoonful of salt; 2 teaspoonfuls yeast powder ; 3 tablespoonfuls butter ; I egg ; I tablespoonful white sugar; $\frac{1}{2}$ pint sweet milk. Sift the flour, powder and salt together rub in the butter cold, add the egg slightly beaten, then the sugar, and milk; mix into a smooth dough, just soft enough to be easily handled. Roll out in two pieces, thin to size required; lay one on top of the other, and bake in a hot oven in a well-greased pan, about fifteen minutes. Separate while yet warm, not hot, use one for bottom crust with a layer of nice ripe berries on it, well sugared, then lay on the other piece, and cover with berries as before, sprinkled well with sugar. Serve with cream ; whipped cream is preferable. The berries should not be cooked. Slice the cake in pieces about two inches by two and a half inches in size, before covering with cream and sending to the table. Ordinary spongecake made in layers can be used in this way, and blackberries or raspberries instead of strawberries.

June 23.-We have been very busy to-day weeding. It is extraordinary how swiftly weeds grow and how slowly in comparison flowers. I feel I should like to have a Frankenstein's Monster solely for weeding. I should never need to say the word that would stop its work, I should think. There is an old saying, "The frost hurts no weeds," and another, sadly true, "One year's seeding is seven years weeding." The Saxons rightlyindeed called June the Weed month.

I heard a most interesting description to-day of a Japanese miniature garden brought home by a lady, who had visited Japan, to her house in England. It was a garden in a sort of large teatray, containing tiny Azaleas I 88 


\section{A Thirsty June}

about an inch high, and small Maples and Stone Pines about a foot in height. There were little Oaks too, said to be about thirty-two years old, and no taller than the Maples. The tallies were written in Japanese, and must have looked very funny. This dwarfing is an expensive and somewhat troublesome process, I think, and in consequence these gardens are rather costly to buy. At Japanese flowershows I believe specimens of these Dolls' gardens may often be seen improved (?) for the popular taste by tiny houses or lakes with bridges. I have been told there is a wonderful Rock-garden to be seen at Lamport Hall, near Market Harborough, where the object of the owner has been to gather round a number of tiny caves and miniature mountains, vegetation in proportion. Here there are Cedars and Fir-trees not over $5 \mathrm{ft}$, and curious Alpine plants, one very old Aloe scarcely $5 \mathrm{in}$. high, and tiny miniature Ivies growing on tiny trees. Everything is growing, and it has taken years of trouble to bring the Rockery to the perfection it has attained. In the midst of the Rockery are some caves made of bits of sparkling quartz, and miniature Earth elves, about 3 inches high, with mining tools, are stuck about dramatically posed. But I question whether the effect can be improved by these manikins. Curiously enough, the clever gentleman who has invented all this bears two rather appropriate mottoes : "I show, not boast," and "On things transitory resteth no glory." This last assertion, however, I think, is open to doubt. I believe the only other outdoor garden of this kind in Europe is one belonging to the Emperor of Austria. But they do not seem, on a small scale, to be very uncommon in Japan. I should like to see one as a curiosity, but I doubt if I should really care about it. Japanese literature seems to be very rich in writings about nature and flowers. At the very time when old John Parkinson was writing in England about his garden of Pleasant Flowers for Queen Henrietta Maria's benefit (to whom, by the way, we owe so many of our pleasant fruit-trees, there was a man named Yekken writing about gardens in Japan. His book, "The Philo- 


\section{Stray Leaves from a Border Garden}

sophy of Pleasure," is said to be rather in the style of Ruskin. He writes, "It tends to edify the heart if we plant trees and herbs in our gardens and love them." I quote this from an interesting book on the History of Japanese Literature by a Dr. Aston, sometime attached to the British Legation in Japan. How lucky it is for vegetables such as I, who cannot leave their little homepatch, that there be folk, butterflies, and bees, and suchlike, able and willing to bring to the homebound, histories of the doings of similar earth-held ones elsewhere! The Bees in the old pottage-garden have been very busy all this sunny weather. There is a good deal of Bee-keeping about here and very good honey to be got. The Bees all depart to the hills when the heather is in bloom, cartloads of Bees journeying to the moors, summer's pilgrims, to bide awhile under care of some Shepherd in his lonely shieling, that the honey may acquire the esteemed heather flavour. Réaumur describes the Egyptian Bees travelling from Lower to Upper Egypt when the pink Sainfoin is in flower, journeying in boats on which the hives are high heaped in pyramids. Among the many enemies of Bees, they have here especially Tit-mice and Sparrows, who watch by the hive-door and often seize them coming in or out; indeed, I am told the wily birds actually tap on the door to entice the Bees out! Mice, too, are very fond of eating Bees. There are many strange stories about Bees, and I heard the other day a most curious one about a Snail who went into a hive, and as the Bees could not get rid of him, they actually plastered him up in his shell and made a sort of monument of him inside the hive ! I never look at a hive snugly ensconced under a sunny espaliered wall without thinking of my "aïeule's" quaint "devise," the little Beehive with the motto, Un asile et des fleurs. Poor Lady Edward! I am glad to think that in her sorrowfraught wandering life there were spells of rest and peace when this her prayer was granted. Bees are said never to touch the sweet clear drops in the Crown Imperial flower, 


\section{A Thirsty June}

and they certainly seem to have fancies in flowers, Scillas, Arabis, and Clover being evidently grateful to them.

About the Crown Imperials and Bees I am rather doubtful, however, as I watched a Bee the other day go up inside the flower and certainly stay there a long time, and I think he must have been taking the honey-drops. There is a local belief the stings of Bees are a cure for rheumatism. An old village elder told me he had applied this cure only a few days before to a man suffering very much. I inquired with interest if the patient was cured. But the doctor "had not seen him since!" An old Lancashire cure for rheumatism used to be Goose-grease. I think I should have preferred that to the Scotch cure. To dream of Bees is said to be lucky. I heard such a curious story about Bees the other day. A boxful of knitted helmets was sent to some soldiers in South Africa, and when opened one of them was found to be doing duty as an impromptu hive, being full of honeycomb and Bees! Bee-masters get quite knowing about their Bees, and say the Bees know people apart. I do not know whether any of the Border Beemen have their Bees in such good order as to be able to let them loose, like dogs, on people, and call them back, as I have heard some Soudanese mountaineers are able to do. Some Egyptian soldiers were once, so the story goes, sent to levy taxes for the Government on the Nubas, a set of wild mountaineers somewhere in the Soudan, and the tribe let loose their Bees on the soldiers, and only consented to call them off when the Egyptian commandant agreed to the terms of the Nuba Sheik. I was interested to learn recently that the old practice of banging tin pans, \&c., when Bees are swarming, originates in the old Roman law of Justinian, that any one was free to pursue a flying swarm provided he let all the world know it by ringing a bell or otherwise making a noise. It is commonly believed now that the din is a pleasure to the bee! In Cutwode's "Caltha Pœtarum" is the following delightful description of a Bee going on a pilgrimage : 


\section{Stray Leaves from a Border Garden}

He made himself a pair of holy beads :

The fifty aves were of gooseberries ;

The paternosters and the holy creeds,

Were made of red and goodly fair ripe cherries:

Blessing his marigold with ave-maries

And on a staff made of a fennel stalk,

The beadroll hangs, while he along did walk;

And with the flower monkshood makes a cowl,

And of gray dock got himself a gown, And, looking like a fox or holy fool,

$\mathrm{He}$ barbs his little beard and shaves his crown;

And in his pilgrimage goes up and down :

And with a wabret leaf he made a wallet

With scrip, to beg his crumbs and pick his sallet.

A Wabret-leaf is old Scotch for a Plantain-leaf, from the Anglo-Saxon waybrede.

William Lawson, that delightful old-time gardener, says, "Store of bees in a dry and warme Beehouse, comely made of Firboordes, to sing and sit and feede upon your Flowers and sprouts, make a pleasant noyse and Sight." Certainly a garden without Bees would be almost as bad as a garden without Birds. The other day, as I was leaning over the little gate by the Gardener's cottage, a man came by who told the Gardener's wife if she wished a fine swarm of bees, her husband would find one in the village poorhouse, which, for want of use, is nigh a ruin. To-day I find the swarm is snugly installed in a tea-box close to the Carnation-bed.

To be beeheadit was an old Scots term for being unsettled. 


\section{CHAPTER VIII \\ MIDSUMMER TO MICHAELMAS}

June 25.-Midsummer Day. This is the month of Roses. We should have plenty of Roses were it not that it is rather too dry, though I did not think to be saying so in Scotland, where foreigners think we never see the sun. I do love to have Roses everywhere, as I have seen them in some old French gardens, especially in my mother's garden, where a Thè Homère grew so high, and withal so heavy, I remember it had to be supported by massive stobs In Ritson's "Ancient Songs," in the Dead Men's Song the idea of heaven is so pretty:

\section{The fields about this city faire \\ Were all with roses set ; \\ Gilly flowers and carnations faire \\ Which canker could not fret.}

In my old Herbal, Gilly-flowers are figured as single sweetsmelling Pinks. Gilly-flowers are also mentioned in the Scotch ballad of "Clerk Saunders." They are sometimes thought to have been Rockets, or Wallflowers, not Pinks. The Italian word both for Pinks and Gilly-flowers is Garofano, while Sweet-williams (Dianthus Barbata) are Garofanetto salvatico. The word Gilly-flower is said to be a corruption of Carophyllus, meaning the "nut-leaved." This name began with the Clove-tree, and was transferred to the Clove-pink because of a fancied resemblance, I believe. In the "Winter's Tale," Shakespeare makes Perdita talk of Gilly-flowers and Carnations. 


\section{Stray Leaves from a Border Garden}

June 28.-I saw something small and black to-day moving among the grass-blades on the edge of the croquetlawn, and I promptly caught it in my hand. It proved to be a Mole, which struggled most violently. I put it down on the short grass of the lawn, thinking I could easily pick it up again. But I was mistaken. In a second it tore up the grass with its tiny-clawed pink hands and disappeared like a flash of lightning into the earth, darting down like a fish in water. We could trace its progress for a moment by the slight upheaving of the grass, showing where it was burrowing underneath, and then it was gone entirely. I never saw such a swift disappearance and, had I not seen it with my own eyes, would never have credited that so unwieldy-looking a little beast, like a soft black velvet sack, could move so fast. Boy sings a funny little song about the Mole. I don't know who taught it to him :

The Moudie warp, the Moudie warp,

Hackit a hole in the meenister's park,

And oot creepit a sma' wee Moudie warp.

I think this word is from the Saxon moldwarp-earthworker, and a park is a field, from the Cymric parwg, meaning an enclosed field. Moudieskin purses used to be thought a lucky possession by Scotch peasants. I think I will have one. I do like some of the local names of places hereabouts, they are so quaint-Swallow Dean, Pyat Knowe, or Magpie Hill, Catchapenny, Crawdene, Lint (or Flax) Mill, Green Knowe, Orange Lane, Corbiesha', and Houlet's ha', meaning Crow's hall and Owl's hall, Earn's heugh, Hartland, Laughing Law (Law being " hill "), Eagle's cliff, and Elfhole. They are generally of old date, too, these names, and of local explanation, as in the case of Earnsheugh, Eagles having frequented the place. Orange Lane is said to owe its name to the Oranges in the coat-of-arms of one of the local families, while of Velvet Hall, at present a little country station, I cannot find any explanation beyond that Professor Veitch says "hall" comes from "heal, a stone," and originally meant a house or enclosure of stones. 


\section{Midsummer to Michaelmas}

June 30.-The Sycamores are looking so pretty with their bunches of red keys! They are sometimes called Plane-trees, and tradition declares Mary Queen of Scots first introduced them into Scotland. In the grounds of Holyrood, I believe, the two Planes may still be seen which she planted on her return from France, called "Queen Mary's trees." She is said nearly always to have planted a tree whenever she stayed in a strange place. In the village of Little France, close by Craigmillar Castle, an old Sycamore, said to have been planted by her, used to be shown to visitors. In the West of Scotland, Sycamores are sometimes called Dule-trees. Dule means "sorrow." Dule-weeds are the garments of mourning, probably from the French devil, mourning; and the trees seem to have acquired this name because they were often used as a gibbet by the lord of the castle. I believe there is a notable specimen of a Dule-tree still to be seen near Cassilis Castle, on the River Doon, called the Dule-tree of the Kennedys. On the Border, if the Sycamore is found wild, it is generally a sign that formerly there must have been a house or village in that place, since it is said to have been the first foreign tree introduced, and consequently generally planted by some noble's house.

I wonder if Shakespeare's song about the poor soul who sat sighing 'neath a Sycamore-tree meant that any of her kin had been hung upon it? Border barons behaved in much the same way on either side of the Border. In Wilson's "Tales of the Border" there is a delightful story of a Border Laird who took his neighbour prisoner and offered him the choice between wedding his ugly daughter, Muckle-mouthed Meg, or hanging from the Dule-tree. The Syringa is in full bloom everywhere; the air is heavy with the scent; there are masses of Roses also. How I love Roses! I quite agree with Sappho, who so many long years ago called the Rose the Queen of Flowers. And yet it is the flower above all of the poor. Hardly a patched tumble-down cottage but has its gallant climber with drooping heavy heads, and a poor hedger may be seen at the 


\section{Stray Leaves from a Border Garden}

Kirk with a rosebud that might fit a king for a buttonhole. There is a time when the lanes near here are fairy highways with the china pink buds of the " Pimpernel Rose," the briar, and homeward-wending bairnies from the school break recklessly bunches of fleeting beauty that would be paid for with silver in city streets.

It used to be the custom, I believe, long ago in England, and I think in Germany and Denmark as well, for a White Rose to be hung up over any table where secrets were likely to be discussed; hence the saying that things meant to be kept secret were mentioned as being "Under the Rose." The Greeks consecrated the Rose to Harpocrates, God of Silence. I wonder if there was any connection between this and the Northern custom of "Under the Rose"? Roses were sometimes used as a form of rent. I remember hearing of an old place in Yorkshire, where the owners were supposed to send a Red Rose to the Queen at Christmas. There is, I believe, still to be seen an old Charter granted by King David II. in favour of one John de Raynton (Renton), burgess of Berwick, of the lands, \&c. of Bily, in the barony of Bonkyle, within the Sheriffdom of Berwick, in fee and heritage, therefor yearly a Rose at the Feast of St. James the Apostle, and to the Lord of Bonkyle 8s. for the ward of the Castle. Dated at Edinburgh anno regni 17 mo. 1346-7. Billie has long passed from the heirs of John de Raynton, and happens to be in our possession. But we pay no tribute of Roses; I could not bear to part with even one, I think. Such a lovely variety of Roses! - tiny palest pink Scotch Roses, yellow Ayrshire, bonâ fide Tea-roses, Allen Richardsons, Cabbage-roses sweetest of all, pink and white Moss-roses. What is the old saying: "Red Roses for joy, White Roses for comfort"? And why? There was a time, I believe, when to wear a breast-knot of White Roses meant you had Jacobite proclivities. In a pretty miniature of Flora Macdonald I saw once in an old curiosity-shop in Edinburgh she had a White Rose tucked in the folds of her plaidie. I afterwards heard that she is said to have sat for her picture Ig6 


\section{Midsummer to Michaelmas}

when she visited London, and the painter insisted upon putting a Jacobite Rose into the picture in spite of Flora's denial she had any Jacobite leanings, for it is said she and her kinsfolk were Hanoverians, and she only saved the Stuart Prince from an impulse of womanly pity. Alas, for the deadly dulness of the history-books of the future, when all the romantic stories shall have been thus weeded out of them. In an old book called "The Scotish Minstrel," arranged for the Pianoforte by $\mathrm{R}$. A. Smith in the simple style our grandmothers loved, there is a Jacobite air called "Carlisle Yetts." Mentioning the White Rose, the forlorn sweetheart laments thus :

My father's blood's in that flower tap, My brother's in that harebell blossom,

This white Rose was steeped in my luve's blood, And I'll aye wear it in my bosom.

The Lilies are now really lovely-scarlet Turncap, and a great orange-red Lily, like a glorified Orangeman-Lilium atrosanguineum, I think, is his proper name-stands like a king in the border along with white Canterbury Bells, like fairies' nightcaps. Coventry Bells they are sometimes called, and Viola Mariana and Mariets.

July 2 2.-We had a few Strawberries to-day, and are hoping for more to-morrow; also, at last, Green Peas. The following receipt for "Spring Soup" is out of my old family Recipe-book. It is curious to think it is over two hundred years old. To make Spring Soup: "Take I 2 Lettices, cut them in Slices and put them in strong Broth, get 6 green Cucumbers, pare them and cut out the Cores, cut them into little Bits, and scald them in boiling Water, and put them into your Broth; let them boil very tender, with a Mutchkin of young pease and some Crumbs of Bread."

The purple Gladiolus is out now, and the Golden Eschscholtzia, or Californian Poppy. I am so fond of it! The Giant Mullein are, indeed, High Tapers now, and look beautiful. In Lanarkshire they are called Shepherds'-clubs. 


\section{Stray Leaves from a Border Garden}

Fairies' Blanket-flower Boy and I call them. It is odd a North-country name should be Adam's Blanket. I am going to plant more. The Tansy in the garden is thicker than ever, though $I$ have had some rooted out, and put on the haugh. It is said to grow wild in places near here, but I have not seen it wild. I am not very partial to the smell. The Tansy cakes obligatory at Eastertide in old days must have been odious, though apparently they were considered a dainty, as "a Tansie" figures in a curious old bill of fare still preserved in the Marchmont archives as having been served before Patrick Home, Earl of Marchmont, when keeping house in Holyrood as Lord High Commissioner in 1698 . Here is a receipt for a plain Tansie out of my ancient Cookery-book which may well have been such as was set before his Grace the Lord High Commissioner : "Take a fine stale Penny loaf, and cut the Crumb in thin Shaves; put it in a Bowl, then boil a Mutchkin of Cream, and when boiled, pour it over the Bread; then cover the Bowl with a Plate, and let it ly a Quarter of an Hour ; then mix it with eight Eggs well beaten, two Gills of the Juice of Spinage, two Spoonfuls of the Juice of Tansy, and sweeten it with Sugar, Nutmeg, and a little Brandy; rub your Pan with Butter, and put it in it; then keep stirring it on the Fire till it is pretty thick; then put it in a buttered Dish; you may either bake it or do it in the Dripping-pan under Roasted Meat." Perhaps, however, the following was preferred: "To boil a Tansy, cut the bread as in the other Tansy, and pour a Mutchkin of boiling Milk on it, cover it up, then beat eight eggs with a little of the Grate of a Lemon or Orange, Nutmeg or Sugar; put to it some Juice of Spinage, and a little Tansy juice, stir all well together, then tye it up in a cloth, and boil it an Hour and a Half; when you dish it, stick it with Candied Orange and cut a Seville Orange in Quarters round it, send beat Butter, white Wine and sugar in a Cup with it to the table." Another recipe for a Pipin Tansy was pretty much the same, with the addition of "sliced pipins." This, however, instead of being tied in a cloth, was beaten, then with the 198 


\section{Midsummer to Michaelmas}

slices of apple was fried or baked in the oven. All these recipes are out of Elizabeth Cleland's "New and Easy Method of Cookery," and as set forth on the title-page, "Chiefly intended for the Benefit of the Young Ladies who attend Her School." It was printed for the author in Edinburgh in 1755 , and (I quote the title-page)

"Sold at Her House in the Luckenbooths."

Tansy does not seem in any request nowadays in the kitchen; I have never known a cook ask for it. But its virtues are still recognised beyond the seas. In Virginia the negroes make Tansy-tea for colds, and at a pinch Mas'r's cook will condescend to use it in a sauce.

It was also used as a Cosmetic long ago. "Soak some Tansy in Buttermilk for ten days, then wash ye Maidens faces," if you wish them to gain beauty. An old recipe for keeping meat used to be rubbing it with Tansy.

July 4.- - I found a lovely dark crimson Rose out in the kitchen-garden to-day, which Gardener says is the oldfashioned Scotch Rose, known as the Velvet Rose. There is also an abundance of a beautiful large-petalled single pink Rose like an old-fashioned Damask; its bushes are very low, and bright-green leaves. The old border of great Orange Lilies (Thunbergianum) and tall slim white Canterbury Bells is now a very pretty sight, looking down it from the garden-gate. Mercury's Violets is another name for these, also Our Lady's Nightcaps. The pink Cabbage-roses are coming out in masses, also Idéale and Niphetos, and plenty of old-fashioned single Pinks, very sweet-the Gillyflowers of the old Herbalists. In the legend of Sir Owain there is a delightful description of the Earthly Paradise, where the blessed are said to arrive after passing through Purgatory:

Fair were her erbers with flowres,

Rose and lili divers colours,

Primros and parvink ;

Mint, feverfoy, and eglenterre 


\section{Stray Leaves from a Border Garden}

Colombin, and mother wer

Than ani man mai bethenke,

It berth erbes of other maner

Than ani in erth groweth here,

Tho that is lest of priis ;

Evermore that grene springeth,

For winter no somer it no clingeth,

And sweeter than licorice.

(From Minstrelsy of the Scottish Border, by Sir W. Scott.)

July 8. - I heard the Cuckoo this morning calling several times. It is only the second time I have heard him this year; he is rather a rare visitor about here, and does not stay long, going farther north. I believe he is more often heard on the heights of the Lammermoors. The Japanese and the Finns both look upon the Cuckoo as a sad bird. With the Finns he is a sacred bird, and is associated with misfortune, and in particular with unhappy lovers. The following is rather a curious little extract from John O'Mahony's translation of the "Kalevala," the sacred book of the Finns :
When I hear the cuckoo calling,
Then my heart is filled with sorrow,
Tears unlock my heavy eyelids,
Flow adown my furrowed visage,
Tears as large as silver sea pearls.
Older grow my wearied elbows,
Weaker fall my aged fingers,
Wearily in all my members
Does my body shake in palsy,
When I hear the cuckoo singing,
Hear the sacred cuckoo calling.

The Japanese also think of the Cuckoo in connection with unhappy lovers. A poet named Akahito, who lived in the eighth century, wrote a poem on Spring and the Cuckoo, which appears prettily translated in Aston's delightful book on Japanese literature. To me the Cuckoo's call is such a cheerful sound, the "Messengere of Spring," as Spencer calls him. I think Mahomet must have been partial to the Cuckoo, for it is one of the selected ten creatures, he told his followers, were permitted to enter 


\section{Midsummer to Michaelmas}

Paradise. He could surely not have been acquainted with its evil behaviour towards its foster-brethren, or he would scarcely have honoured it thus, one would think. Near here there is a village named Gordon, and there is an amusing legend that the good folk of Gordon once proposed to build a wall round the Cuckoo to keep the Spring at Gordon. They thus earned for themselves the name of the "Gowks o' Gordon." Gowk means both a Cuckoo and a silly person.-We are very busy now making Green Gooseberry-jelly; it is odd it comes out pink! The only green jelly I ever saw was made of unripe green Grapes. Here is a curious old recipe, from mine ancient book, for what would seem to be a nice sweetmeat. I think I must try it. Gooseberry Paste: "Take them when full-grown, wash them and put them into the preserving Pan, with as much Water as covers them; boil them very thick all to a Pommish; then strain them through a Hair Sieve into a Pan, and press out all the Juice : and to every Pound of this Paste take I Pound and 2 Ounces of Sugar, boil it till it cracks; then mix in your Paste, and let it incorporate with Sugar over a Slow Fire; When it is well incorporate, skim it and fill your Pots, then skim it again, and when cold put it into the Stove. When it is crusted on the Top turn them and set them in the Stove again, and when a little dry, cut them in long Pieces, and set them to dry quite; and when they are so crusted as to bear touching, throw them on Sieves, and dry the other Side, and put them into Boxes. You may make them red or green, by putting the Colour, when the Sugar and Paste is all mixed, giving it a Warm all together." We have also been making Rhubarb-jam. This last one can never Buy, as it does not Travel. Some people put ginger in it, I think; a little improvement, certainly. Vegetable-marrow and ginger make a nice preserve, but it is not every one who likes it; a little goes a long way. The Strawberries are ripening fast, so we shall soon be making Strawberryjam. What an odd name for Black Currants, the old "Squinancy Berries!" I wondered for a long time what could 


\section{Stray Leaves from a Border Garden}

be the meaning of such a name, but found it was a corruption of Squinancia, the old term for Quinsy: Black Currant jelly being sovrain for sore throats. Another old name for these was Gazles, a possible corruption of the French Groseilles, and they have been also called Blackberries. Red Currants used to be called St. John's Berries and Garnet Berries and Raisins. I do not find any very peculiar names current here for either of these fruits, though they are popular, growing in every garden-patch, and known collectively as Berries. Oddly enough, though the bunches of Red Currants suffer from the attentions of the birds, and have to be picked before they are fairly ripe, the White are left untouched. The flame-coloured discs of Gaillardia are out now. I wish I knew a common name for this-it does not seem to have one. The pink variety is very pretty, and the first bloom of lovely pale pink large-flowered American Bellbind (Calystegia rosea)-Ground Swallower it should be called ; it is too free a grower to please Gardener. The Monkshood is in beautiful clumps of flowery spears all along the garden border, and a white blue-edged one, which Gardener calls Elijah's Chariot; why, I do not know: certainly the flowers do rather resemble Roman chariots. I have seen it in cottage-gardens sometimes, but it is not as common as the blue variety. The Crimson Gladiolus, called French Cornflag in old days, has been very beautiful this last week. I have the kind which grows wild on the Riviera in the Olive-yards, and another little larger, but the same odd Magenta colour. Although scarcely one of the prettiest colours on Madam Nature's palette, yet I love it for old sake's sake.

I picked the first bunch of Sweet-peas to-day; they are like butterflies caught in a green tangle. I prefer growing them in a mixed hedge to the plan so often adopted now, of patches of different hues. And I like better the Peas scrambling up sticks from the wood, than to see the vines tied formally on wire-fencing; a modern improvement! I think Cowper and Tom Hood are almost the only poets who have sung the Praises of the Sweet-pea, and yet it is so 


\section{Midsummer to Michaelmas}

pretty and graceful! The Quaking Grass has been lovely. I do like the old names for it so much!-Panick Grass and Ladies'-hair Grass. The French name is Amourettes tremblantes. The yellow Bartonia beside it in the border is not, I think, very pretty. The Syringa is beginning to go over, but the perfume of the Cherry-laurel is rivalling it in the air. Syringa is really the right name for Lilac, but has somehow always clung to the Mock Orange, which some people are trying to get called by its proper name of Philadelphus. As I was busy to-day raking dead leaves from around the roots of some laurels, which form a shrubbery in the deep shade of the old "Bloody Beech" (Scotticê for Copper Beech), where they do harm if they congregate, I unearthed a family of Hedgehogs, a mother and three dear little Hedgepigs. Of course, on being touched, Master Piggy promptly rolled himself into a ball and lay on his back in my hand, winking up at me with a cunning eye. So I put him down, and Boy and I covered them up again with the dead leaves, and I put a saucerful of milk near them. Boy was exceedingly delighted with them, and stood a long time watching them as they moved faintly and uneasily under the leaves. He has been reading Mrs. Ewing's charming story, "Father Hedgehog and his Neighbours," so was particularly interested in this little family. In Sir Thomas Browne's "Vulgar Errors," he mentions a curious receipt for seeing in the dark: "Boil the right eye of a Hedgehog in oil, and keep it in a brass pot!" Late in the evening I went again to look at the Hedgehogs, and saw two tinies rambling about under the Copper Beech. I put a handful of Red Valerian leaves and flowers close to the milk, in hopes they might fancy it, as Mrs. Ewing says they are partial to Valerian. I wonder if it is true they roll about on purpose in the dead leaves till they get all covered with leaves sticking on their spines, in order to keep themselves warm in winter? It is said Hedgehogs kill Adders, and never seem to suffer from the poison. It is curious that swine likewise kill snakes. I hope the Gamekeeper will not find my interesting protégés, as in that 


\section{Stray Leaves from a Border Garden}

case I fear they would have but short shrift. They are called Hedgaboors in Cornwall. I believe they eat slugs and snails, but the Gamekeeper says they are hard on the Pheasants' eggs. Some people say they eat mice, so perhaps it would be a good thing to keep one in the kitchen instead of a cat. We don't seem much troubled with slugs and snails here; I never see whole picnic-parties of them abroad in the garden as I used to do in Devonshire, ruining my flower-beds. I do like the Shetland name for slugs - "storey or large worm." Gardener says that sometimes slugs and snails trouble the Lettuce-beds and also the Strawberries, but "come a fine sunny day, and the hot sun shrivels them up like." I should like to see the process. Further, when I inveighed against them, he said there were troubles and drawbacks in all professions of life, same as the slugs and snails were those of the Gardeners. Herein I cordially agreed, and when retracing my steps to the house it did occur to me that the old Horticulturist was right who asserted that " a discomposed fancy was reduced to a more sedate temper by contemplation of the miracles of Nature a garden affords," since, in spite of Weeds, and Slugs, and Snails, I generally find a visit to the Garden soothing; and I think, in winter, why I find it more difficult to be even-tempered, is because visits to a bare dead garden are depressing. An old Scotch name for the Hedgehog was Urchin. In Leyden's picturesque poem, "The Cout of Keeldar," when the Wee Brown Man of the Moors is seen by the Border chieftain,

An urchin clad in prickles red

Clung cowering to his arm.

The sunset was quite glorious this evening; the sky seemed all on fire beyond the firs in the avenue, while the Lammermoors were very clear and dark blue, a bad sign with us, though the saying round here is :

Red in the morning, the shepherd's warning ;

Red at night, the shepherd's delight. 


\section{Midsummer to Michaelmas}

From the village across the river came the sound of a fife. I do not know who is the player; he was evidently not very accomplished, a simple, very simple rendering of "Robin Adair," and a reel or two, seemed all he could do ; still it sounded very pretty in the evening stillness.

July 9.-The Honeysuckle, which hung in such lovely masses among the dark Ivy on the walls of our little twelfthcentury Kirk, is all over now-no more "Ladies'-fingers"; but there is a beautiful bush of "Prince Charlie" White Roses in bloom by an old mossy tombstone, the White Rose which used to be so common in Scottish gardens long ago. We have a similar bush in the kitchen-garden, but when I spoke of it as "Prince Charlie's " Rose to the Gardener, he said it had always been called the "Colonel's" Rose, because an ancient beau who had lived in past days in the old mansion-house loved it for buttonhole bouquets. Many are the quaint stories about this old veteran : he had an invincible dislike to having a tree cut or bush pruned, a state of things which resulted in the "House in a Wood" or Palace of the Sleeping Beauty, which we found on coming to live here. He would go to Auld Reekie or London Town with the money he allotted himself for his jaunt tied up in an old stocking-foot, and when nothing remained but enough for the homeward journey, which indeed had been in a separate packet from the beginning, he would say it was time to be jogging homeward. He was in the habit of wearing a white satin nightcap embroidered with pink rosebuds, which indeed survived long after his death in some corner aumrie, where was also a Malacca cane with carved ivory dog's head and silver band, with which he used to walk in the garden, and which I now walk with in all his old haunts.

July ro.-Rain, no wonder to us after the too gorgeous sunset. The Hedgehogs have disappeared, to our grief. There is a lovely dark purple Summer Iris out now-Iris Xiphoides_and masses of tall pale pink Turncap Lilies. My blue Meadow Cranesbill Geranium Pratense, from Auvergne, is in lovely bloom, and there is also a beautiful 


\section{Stray Leaves from a Border Garden}

dark crimson variety wild by the river here, and a dark blue one. I have also a lovely white variety. The first Scarlet Lychnis is out; Summer Lightning is a delightful quaint name for it ; it used also to be known as Flower of Constantinople, Bristol Flower, Maltese Cross, and Nonesuch. Croix de Malte is the French name for it. My old Herbal says it is a "Glorious flower, being as Magnificent as it is Beautiful." I think it is a little late in blooming, as an old saw says :

The scarlet lychnis, the garden's pride,

Flames at St. John the Baptist's tyde.

But then it is so cold here, things always bloom later than the dates given in The Garden newspaper. A lovely white Galega-Goat's Beard-is also in bloom, and a giant white Vetch, called Goat's Rue, a great beauty. It rained heavily this afternoon; my poor Pyrethrums look rather the worse for their ducking. I have some lovely pale green Astrantia from Auvergne out now. I wish II had the minor Astrantia, a tiny little variety which grows in the Alps, but it does not appear to grow in Auvergne. I fancy it does not like a volcanic soil. My white Jacob's Ladder (Polemonium) is in bloom, also the pretty grey-blue variety. Pyrola minor, the dear little Wintergreen, is out in the plantation now, under a Beech-tree, looking like a fairy Lily of the Valley, so graceful and pretty. The old Herbals say Pyrola-leaves are good for wounds. My purple-crimson Dog-rose has done flowering now, and its bushes are all covered with the quaintest long-shaped Hips. In Devon, Hips are called Pixy-pears, but these should rather be Pixycucumbers, their shape is so peculiar, I think. Cattijugs is a funny Yorkshire name.

July I 2.-A thunderstorm, accompanied with heavy rain, was our portion to-day. The Rainbow was so pretty over the fields afterwards! There is a delightful old Border saying about the Rainbow:

Rainbow, Rainbow, haud awa' hame,

$\mathrm{A}^{\prime}$ your bairnies are deid but ane,

$\mathrm{An}^{\prime}$ it lies sick by yon grey stane,

$A n^{\prime}$ will be found deid ere ye win hame; 


\section{Midsummer to Michaelmas}

Gang owre the Drumaw and yont the lea, An' doun by the side of yonder sea

Your bairn lies greeting like to dee,

With a big teardrop in his ee.

Drumaw is a high hill near the sea in East Borderland. On the Drumaw there used to be a British fort, one of the few relics of the early Britons; it was also used by the Saxons, sometime occupants of the Border. In Kaffraria the natives call the Rainbow the Great Queen's Girdle, which is rather a nice name, I think. The Roumanians have a fancy the Rainbow is the bridge whereby the angels travel between Heaven and earth. But I like best the quaint conceit of the Algonquin Indians, preserved in "Hiawatha," where old Nokomis sings that the Rainbow is the heaven of flowers :

All the wild flowers of the forest, All the lilies of the prairies,

When on earth they fade and perish,

Blossom in that heaven above us.

But, after all, what is more beautiful than its being the visible token of God's promise to his creatures! The Funkia or Swamp Lilies are almost out now, and the Sweet-pea hedge is looking very pretty. The Lily Garden has been devastated by Moles, the grass has been torn up in every direction; it looks as though a herd of Fairy Cows had been romping wildly over it. He may be useful as a provider of pulverised earth, but he is a great trial to Gardeners ; the Demon Mole, as Keats, I think, calls him; the Little Gentleman in Black Velvet, as the Jacobites called him, drinking his health, after the death of William of Orange. Elder-leaves are said to drive away Moles if spread about where they haunt. I think I must try this receipt.

July 14.-A beautiful day. Boy and I have been busy superintending the upraising of an old Arborvitæ-tree which had been blown down by the gale of yesterday. Boy ran to and fro with a little hatchet, cutting off small branches and directing the men at work, and, like the fly 


\section{Stray Leaves from a Border Garden}

on the coach-wheel, thinking he did all the business. The Melon scent of the crushed branches quite filled the air. It is so nice to burn in winter, it gives forth such a delicious smell, but it is rather addicted to "sparking," which is a bore. One of the men came across a tiny Hedgepig in the path close by, and asked what he should do with it. "Kill it," cried the Gamekeeper in a bloodthirsty manner. But Boy and I protested, and saved the poor little tramp. I gathered him up in my leather-gloved hand. Even so small, his coat was somewhat prickly, like a little Chestnut-burr, and after persistently wetting the tip of his nose with milk, induced him to drink some out of a saucer on the ground. I kept him a little while in my lap, stroking his face and underside, and he partially uncurled himself, as if he liked the attention. White of Selborne says they cannot curl themselves up when very small. The appearance presented by a wee bit Urchin on his back is most comical. He looks like a tiny little old, old Manikin wrapped in a fur cloak, like a picture of an Eskimo elder. The Gamekeeper was indignant at my taking notice of him. "Wad ye gie milk to Jock Bell (naming a noted poacher), gin he cam' to yer ha' door, mem ?" "Yes," I said, "probably, if he was as attractive looking as this little varmint." Whether true or not, the Hedgehog has a very bad character as regards Pheasants' eggs, \&c., in the eyes of Gamekeepers, and he meets with small mercy at the hands of Gipsies. It is said they bake them in earth-ovens till their spiny coats come off in the clay they are rolled in, and reckon them great tit-bits.

July I 5.-St. Swithin's Day. If it is fine to-day, we shall have fine weather for a long time; but if it rains, it will rain for forty days without stopping-a dark outlook. I saw some lovely Hansoni Lilies, yellow, in bloom in a garden near here yesterday, and some most effective clumps of pale blue Larkspur Bella Donna. There was a lovely white Campanula, shot with lilac, coming out to-day in the kitchen-garden, in the border which is just "throng," as Gardener says, with rival beauties elbowing 208 


\section{Midsummer to Michaelmas}

each other; also a pretty scarlet seedling, Chelone Barbata (Turtlehead); it is so pretty, like a scarlet Solomon's Seal without overshadowing leaves. Coral-drops would be a good name for it. It is like a lady's old-fashioned eardrops.

In the Dene there are some Foxgloves. Dene is a word used here for a glen or a hollow, and is an AngloSaxon word. A Dane used to be called a Densman. In Norway the Foxgloves are called Foxbells-Ravebjelde and Fingerböl; and one of the German names for them is rather pretty-Waldglöckchen. They are also called Fingerhut, meaning Fingerstall or Thimble-flower, which is pretty much the same as in Holland and Denmark. Some rather gruesome old Scotch names are Dead Men's Fingers, Dead Men's Bells, Bludie-fingers, Dogs'-lugs, and Bloody-bells. But the prettiest name they bear is at a place called Green Law or the Green Hill, that of the King's Ellwand-I suppose the measuring-stick of the King of the Fairies. In Roxburghshire, Orion's Belt used to be called the King's Ellwand. In Wales the Foxglove is called Elf'sglove; and it is possible the word Foxglove may be just Folksglove, meaning the Gude Folk or Fairies, unless it is from the Anglo-Saxon gliew, the musical instrument. Some old English names are Fingerwort, Fox-finger, and Dragon's-mouth, while, from an old notion witches decorated their fingers with Foxglove-flowers, they were called hereabouts Witches'-thimbles. Fairy-cap is another name, of Irish origin I think, and our Border lassies call them Ladies'-thimbles. In France they are Gants de Notre Dame and Gants de Bergère, and in Italy Guantelli. To-day I went to see the baby Hedgepig in his retreat among the leaves. I found him lying just as I had left him, but cold, cold! I tried reviving him with milk and brandy in a spoon, as the old song says that is good for a swoon, and partially succeeded. But he seemed so ill and faint I took him to the kitchen, and rolling him up in flannel, installed him in a box on the kitchen-range. Presently, on getting warm, he seemed a little better, and 


\section{Stray Leaves from a Border Garden}

Cook and I tried to feed him with milk and sops in milk, but in vain. And late in the day, when I asked after him, Cook, who had taken great interest in the little deserted tramp of the woods, said, "Alas! he is dead!" I was in the Rose-garden; she handed me over the Holly-hedge the poor little body, stretched and stiff, as if he had tried to run away from Death the Destroyer, and "Jock Bell" found a tiny grave in the Lady's-garden under a Rose, with a bit of grey slate for a tombstone, with his name rudely scratched on it. Boy, unfortunately, could not be gravedigger. "Who'll dig his grave?" "I," says the Boy. "Because it's a joy, I'll dig his grave!" But Nurse swooped down on him just then, and it is not always advisable to defer funerals till a convenient moment.

July r6.-Fine day; good for the hay. The Saxons called July Heu monath, or the Hay month. I wish we did still, rather than use the Roman name. Certainly Julius Cæsar is said to have rearranged the Kalendar, so perhaps he might reasonably expect to have one month named after him. The Kirkyard presented a somewhat quaint appearance to-day, as the long grass between the graves had all been mown down, and was fast becoming hay. This crop is by law the minister's perquisite, and he makes it into cocks, which is a strange sight among the grey old stones.

I have heard tell of a minister who went so far as to manure the Kirkyard, with a view to improving the quality of his hay; but I believe the heritors objected, and no wonder. Our church boasts a history. It was given by Cospatric Home, Earl of Dunbar, to the Abbey of Kelso, somewhere about I I 59, and remained in possession of the monks till the Reformation. There is a curious old stone carving, representing two men and a woman, on one of the outside walls with the motto, "Vive Memor Lethi," which, being interpreted, seems to mean, "Live mindful of Death," or rather of the oblivion of death. It was overgrown by Ivy, so we have had it cleaned, also the carving above the figures, which runs thus : 


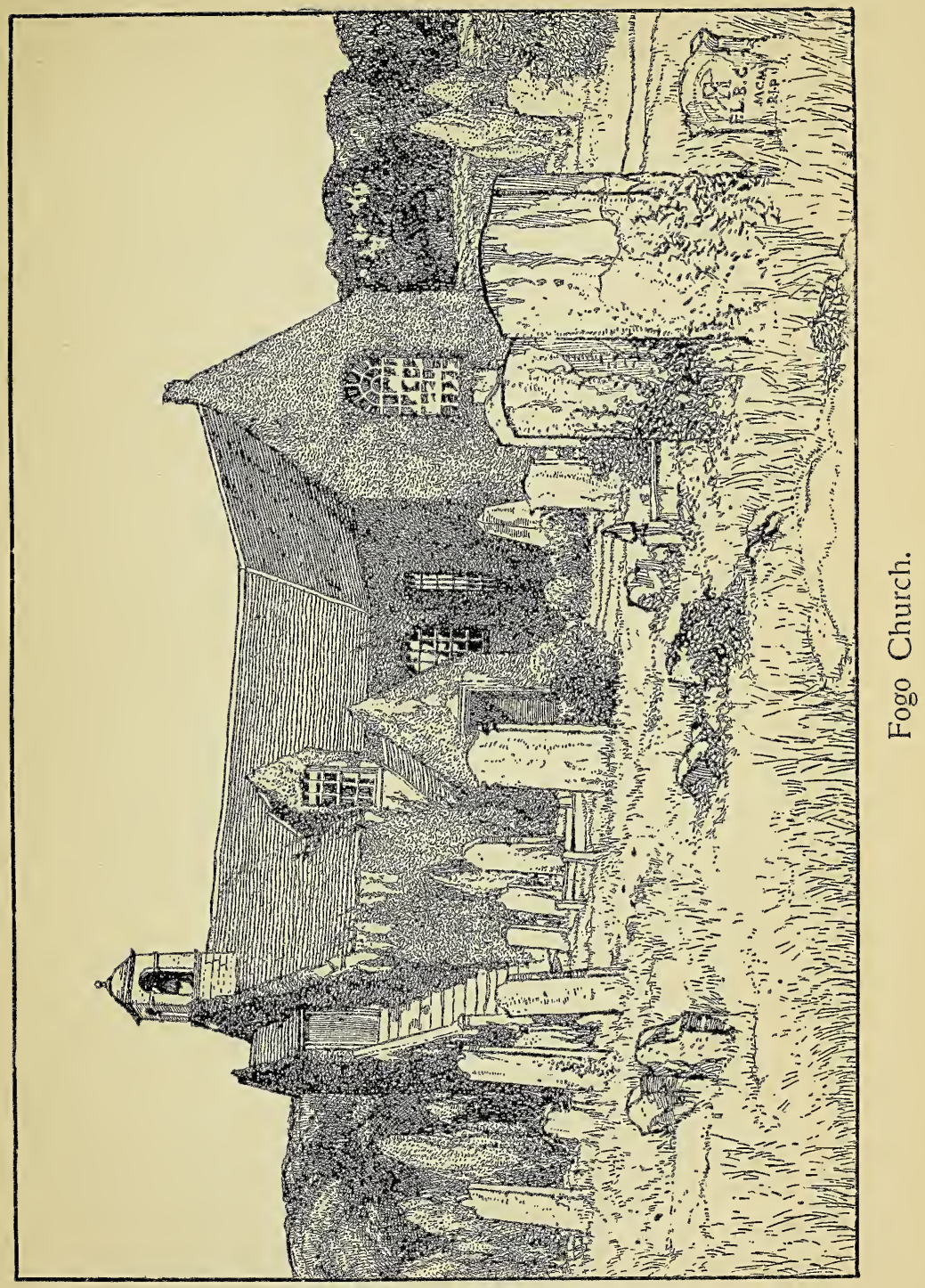





\section{Midsummer to Michaelmas}

We three served God, lived in His fear, And loved Him who bought us dear.

No expert, however, hitherto has discovered the history of this carving. We also acted amateur "Old Mortalitys" about the churchyard, and made clear sundry inscriptions, curious more by their quaint spelling than by their wording. The following one, long said to be here, I have not been able to find:

Here lies the Laird of Whinkerstanes,

The de'il has gotten noo his banes,

He had nae ither God ava

Than Rosybank and Charterha'.

These are places in the parish. Julian seems to have been a common woman's name in past days; it is on several tombstones. Ninian was an old name for a man. There are some of the old tablelike tombstones here. I heard a delightful story the other day of some one who left an order in his last will and testament that spikes were to be stuck on his table-shaped stone to prevent people sitting down on it! And I have actually seen such tombstones in Suffolk. Shall I own that when I spotted a place where a nail had come out I hastened to sit on it?

Some epitaphs are very curious. I came across the following in Melrose Churchyard, which, I think, is very quaint, on a Portioner of Melrose :

\footnotetext{
The Earth goeth

ON THE EARTH

GLISTERING LIKE GOLD

The EARTh goes to

THE EARTh SOONER

THAN IT WOLD

The EARTh BuILDS

ON THE EARTH Cast-

LES AND TOWERS

The Earth says to

THE EARTH ALI SHALL

BE OURS
}

I see the glass-covered painted tin wreaths under glass covers, with mottoes, so common on the Continent, are 


\section{Stray Leaves from a Border Garden}

creeping into use in these Border Kirkyards, which is a pity, as it gives them such a tawdry look. I feel tempted to emulate the English vicar who is said to have gone in the night and smashed them all, considering they desecrated the old God's-acre. Our little church has two galleries which can only be reached by outside stone staircases, and it is nearly smothered in Ivy. There is also a quaint Ivied excrescence which is an old burial vault no longer used, and there is a tradition there are vaults under the church too. In some of these old pulpits two ministers have appeared side by side, but that was in the olden days, and I have never heard that they spoke together. Collections are still taken up by the time-honoured Kirk Ladle, a square wooden box at the end of a long pole, and it would be a bold man who could refuse a "bawbee" to the wide-mouthed ladle, though he might, and perhaps does sometimes, allow the velvet bag in the modern town church to pass him, or puts it off with a sixpence where he could well afford a shilling, for such is the respect for the ladle, that every member of a family, down to the tiniest tot, "thinks shame" to come to the Kirk without a coin, and I have seen a laddie, who had forgotten his ha'penny, very nearly drop a salt tear instead thereof. Over the pulpit there is a sounding-board $(\Delta)$, like a triangular hat of honour, and a few square pews left, but an attempt to be modern is made by unlimited whitewash. At some churches a square box on legs stands outside the door, or a big embossed brass plate guarded by an elder, and never a member of the congregation dares pass in without dropping a small offering. This universality of donation by Scots much surprises other nationalities, and is a custom might be followed, I think, with advantage in other churches, where the duty of giving does not seem to be sufficiently understood. The origin of the word "bawbee" or "babie," is curious, and is explained by a Fifeshire tradition that long ago, when a very infantile Scottish King was shown to his lieges, they had to pay entrancemoney for the sight, and the piece of copper taken from the 


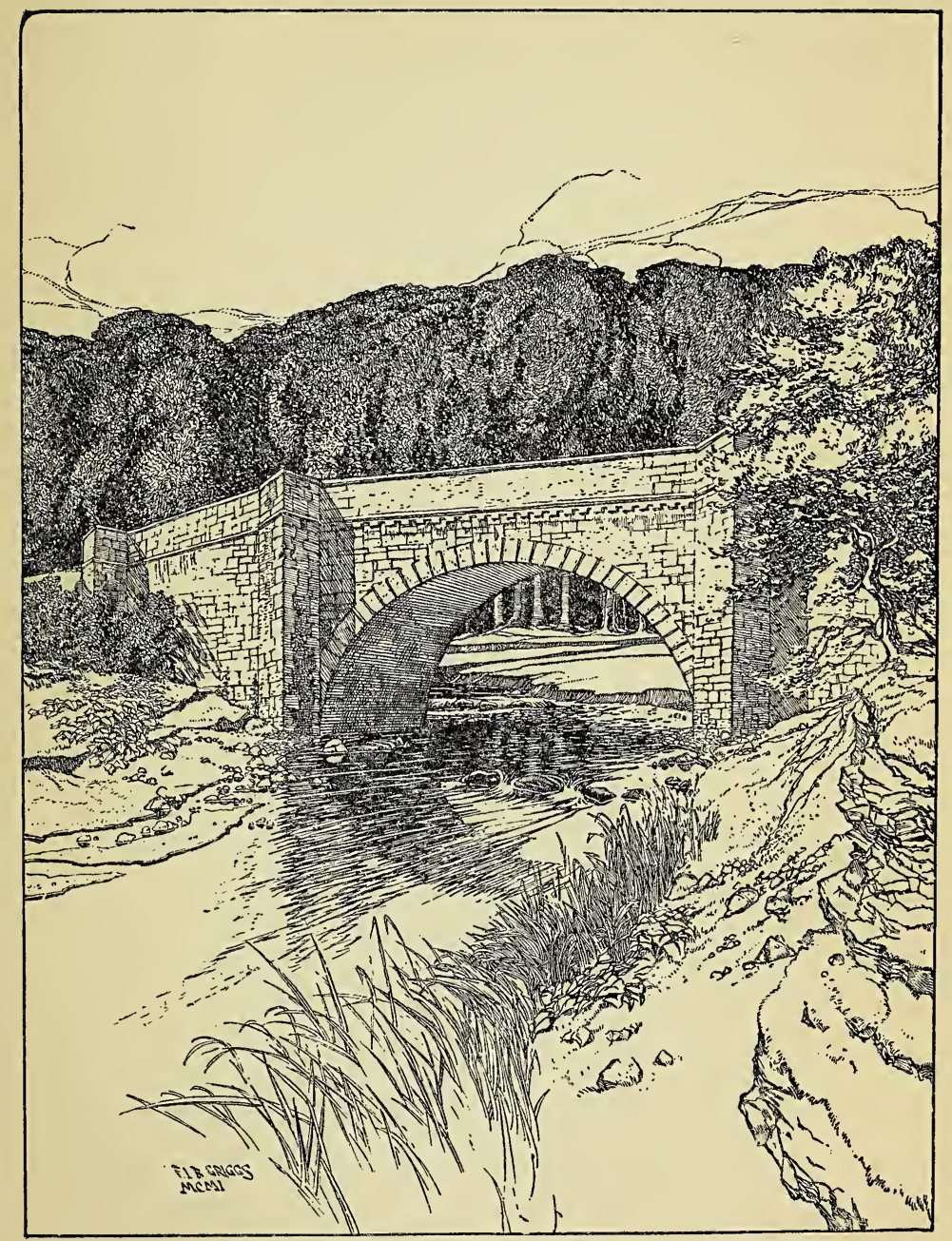

Fogo Bridge. 



\section{Midsummer to Michaelmas}

poorer classes was called in consequence a "babie." Even little babies of three and four have their coin to drop in the ladle, and go through the ceremony with faces of grave solemnity and unwinking eyes. As most of our churchgoers come from a distance, they seem glad of the opportunity of a weekly "crack," and on a fine Sunday I never climb the brae without seeing a number of men leaning against the Manse garden-wall discussing presumably the affairs of the nation, for your hind is a great politician. Then, when the last bell rings, called the "ringing-in bell," they will come hurrying in with their hats on, to get seated before the minister in his black gown comes marching along from the Manse through the Kirkyard (for we have no session-house, Anglicé vestry).

A stranger may think it irreverent to see the hats worn right into the church, but cannot fail to be struck with the otherwise reverent behaviour of all, even down to the tiniest child. Each person follows the Lessons with his own Bible as intently as if he thought to catch the minister omitting word or line, and the Scotch minister's "discoorse" generally gets more attention paid to it than the shorter sermon of the Episcopalian priest. Certainly I have never seen people get up and troop out just as the preacher prepares to begin his sermon!

Boy and I went for a walk in the croft down by Fogo Bridge this evening, and got a lovely bouquet-Crowfoot, purple and yellow Vetches, Grasses, Ragged Robin or Meadow Pinks, Water Avens or Herb Bennet, Queen of the Meadow, Lilac Orchis, dark blue Geranium and Clover, called Sookies, and Sheep-gowans here; the children say they'll be lucky if they find a four-leaved Clover. I remember I used to be told I should see the fairies if I could find one. An old name for the Clover was Meadow Honeysuckle. To dream of Clover meant a happy marriage and generally good-luck. The Clover was also an old love-charm, and there is an old saying :

Find an even ash or a four-leaved clover, And you'll see your true love ere days over. 


\section{Stray Leaves from a Border Garden}

The Scotch say Claver, and the Anglo-Saxon said Clafer. There were big gold-eyed Daisies, or Horse-gowans, as Ox-eye Daisies are called here. The Shetland name for a Daisy is Cockiloorie, supposed to be from the old Swedish words $k o k a$, the greensward, and lura, hid, what is hidden during the winter in the earth, or, as Sir David Lindsay charmingly sings :

Fled from the frost, the tender flowers I saw

Under Dame Nature's mantle lurking law.

We got Forget-me-not, too, on the bank, and Bur Reeds with bunches of beautiful green fruit like tiny Horse-chestnuts. There was a perfect hedge of Meadowsweet along the waterside under the cliff, and abundance of Yellow-flagsGold Sword-lilies, as the Germans so graphically call them. We saw, however, no birds or beasts, except one tiny dead rabbit.

July I 9.-Thunder and heavy rain. The flowers are all rather the worse. The Pinks are coming out at last. I pulled a small log of wood out of a very damp corner, where it had been laying buried in damp leaves, and on part of its bark coming off, a beautiful pattern of white mildew was revealed, looking exactly like white seaweed spread on the brown trunk.

July 20.-I saw some lovely white Turncap Lilies (Martagon album) in a friend's garden to-day, also some herbaceous Clematis in a small bush, very effective. There were some old bushes of Alstromeria or Peruvian Lilies, bright orange and yellow-Herb Lilies they call them here. Also a very pretty bed of Nemisia, an old-fashioned flower one does not often see now.

July 23.-Continual showers these last few days. The flowers are heavy with raindrops. There are some splendid upstanding spires of Giant CEnothera or Evening Primrose. How lovely they must look in their native Patagonian wilds in abundance! The pink Pentstemon border by the Lady's Bower is beautiful. The China Asters are in bud; I do not like to see them, they seem like Heralds of Autumn. The Germans call them Death-flowers. I have heard that 


\section{Midsummer to Michaelmas}

when the late ill-fated Empress of Austria arrived at the Swiss hotel she stopped at just before she was murdered, she found the hotel-keeper had decorated the rooms prepared for her with Asters. She thanked him for the attention with her accustomed grace, but made the remark afterwards to her attendants that the flowers were todtenblümen, such as the Austrians laid on tombs. And after the poor lady's sad death these very flowers were used to deck her lying in state! Boy and I saw a splendid grey Heron flying over the Cornfield to day; his long legs looked so funny stretched out behind him! It is said to be unlucky to see a Heron flying. He was probably going to fish in the river. How strange it is these shy birds are so often to be seen fishing peacefully, quite close to railways! I saw one the other day standing on one leg, as the Indian proverb says, "looking like a saint" wrapt in meditation.

July 24.-The Chestnut-leaves are beginning to turn yellow and litter the avenue. I was very busy to-day getting Linden-flowers, to dry for use in winter. They are delicious dried, and used as a tea when one has a cold. It is used in Germany, and called Flieder Thee. The air was full of their sweet drowsy smell and the Bees were humming in the treetops. In France it is a favourite remedy for colds, as Tisane de Tilleul, but does not seem to be known here. Barry Cornwall's song of the Linden-tree is charming. There are plenty of Lindens hereabouts, but no use seems to be made of them. I quite grieved the other day to see a beautiful avenue of young Lindens in full flower going to waste. There is a French drink, called the Tisane de Sept Fleurs, often prescribed by French doctors for cold and sleeplessness.

Bouillon blanc,
Tilleul,
Violette,
Coquelicot,
Pied de Chat,
Guimauve,
Mauve,

Mullein.

Lime.

Violet.

Poppy.

Tussilago.

Mallow.

Another sort of Mallow.

In Roumania, Lime-trees are sometimes planted in front 215 


\section{Stray Leaves from a Border Garden}

of houses to keep off witches. The beauty of the Orangelily border is over. Well, it has lasted a long time.

July 28.-At last the weather has picked up a little and it is warm. The hay is being cut in the waterside croft and on our haugh. Boy and his little friends were making nests in the hay and picknicking there to-day. It was so pretty " doun by," as they say here: the evening sunlight playing on the brown water where the "trouties" were jumping, and on the masses of brightest blue Helmetflower on the bank, the barefooted, sunburned imps hopping in and out of the water, courtseying on the unsteady stones like Water-wagtails, and shrieking and laughing all the time, the tortoiseshell-cat haunting the bairns' footsteps among the haycocks, probably for love, it could never have been in hopes of mice in the vicinity of such a noisy crew. Pussy's movements are so erratic, I don't wonder a hairbrained person of unsettled ways used to be called Catwittit. Then beyond the old wooden footbridge and rickety watergate a black-and-white cow on the bank, and a red cow meditating in the water, looked a perfect Cuyp picture. The air was full of the scent of the hay and the meadsweet. There is a little Scotch song about the Water-wagtail. I wish I knew who wrote it ; it is rather pretty, I think.

Merry water-wagtail $\mathrm{A}^{\prime}$ the bairnies know

How yer tail wag-wagging Gars the burnie flow;

And how wicked kelpies Tell the frettin' linn

If ye stop the waggin' Burnies winna rin.

Lammas, August r.-Boy is a perfect Waterbaby, he haunts the riverside indefatigably every free moment. $\mathrm{He}$ is not singular in his tastes. I saw a lot of small boys the other day frolicking in one of the burns, and one hot morning, cycling by on the dusty road, I saw two pretty girls in pink dresses sitting with bare feet in the same 216 


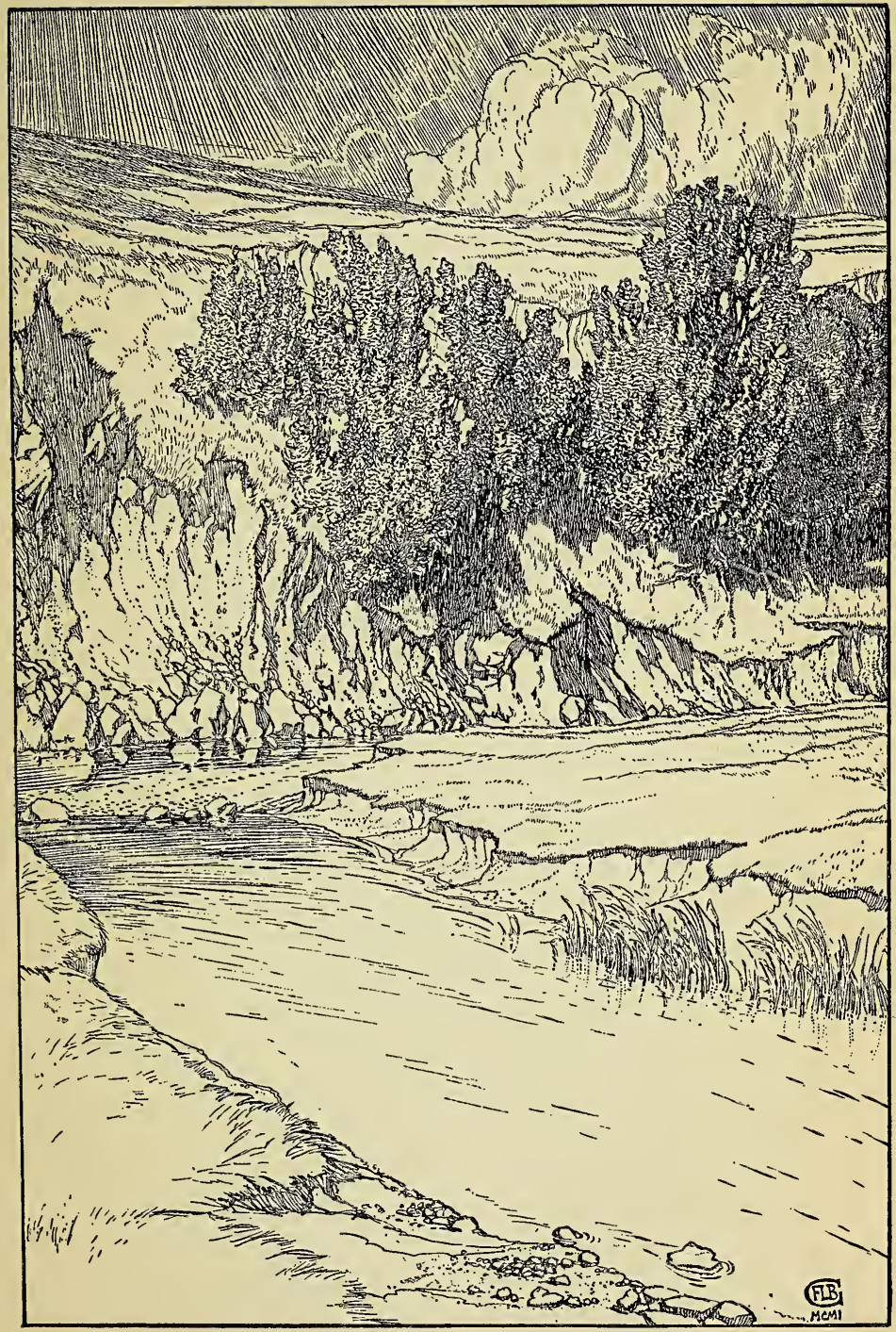

The Blackadder, below Caldra. 



\section{Midsummer to Michaelmas}

stream in the shadow of an old Lime-tree, with their long fair hair flowing over their shoulders. Theylooked like Dryads or Wood-nymphs. The Harebells are out now in masses by the roadsides and Golden Ragwort, called Fizzgigs in the Merse, purple Vetch, yellow Crowfoot, and wild Rasps. The smaller Canterbury Bells are now looking lovely, and I have a Pyramidalis with 2 I splendid blue spires. Clarkia elegans is in bloom, and is certainly a most elegant little bush. The Plume Poppies (Bocconias) and Ox-eyes (Bupthalmiums) are looking very handsome. The Strawberries are over; they do not seem to have lasted as long as usual this year. In Bavaria there is a delightful idea that to ensure plenty of milk the farmer must tie a basketful of Wild Strawberries to each cow's head, between the horns, lest the Elves cause the milk to dry up. The Strawberry was one of the plants dedicated to the Virgin in some places.

August 4.-The Phloxes are beginning; they are delightful old-fashioned flowers, but still, to me, too autumnal to be real joys. The Red Flax is in flower, rather late, I think, owing to the drought. Flax or Lint (Linum usitatissimum) used to be grown in the days of Turner (about r 550) "very plentuously in the north parte of England," and it was grown in the nineteenth century for use by the farmers, who paid some part of their retainers' wages in kind with it. There are places hereabouts whose name tells of this old cultivation, such as Linthill and Lintlaw. On the moors the Linum catharticum was called Fairy Lint, and it was said to be used by the Fairies to make linen. There are many curious superstitions about Flax. In Thuringia, if a maiden at her wedding puts a bit of Flax in her shoe she is ensured against poverty. Another German idea is, if you sprinkle a sickly baby with Flax-seed on Midsummer's Day, the child being laid naked on the grass, as the seeds rooting grow tall and strong so will the baby flourish. In Bohemia there is a fancy that seven-year-old children become beautiful by dancing among growing Flax. In Brittany, on St. John's Eve, lovers - the women bearing Flax-flowers and the men green Wheat-ears-used to gather 


\section{Stray Leaves from a Border Garden}

round a Dolmen and place their flowers on it. If they remained fresh any time, then the lovers would be married; but if the flowers withered quickly, it was considered a sign the engagement would be broken. Mignonette has never put in an appearance with me at all this year, though I see beautiful beds of it elsewhere. I wonder why! I had a lovely crop last year. The Red Carnations are out now. I think Coronations is such a nice old name for them! They are a little late this year. I suppose they were called Coronations because they were used in the making of Coronals or Garlands. Sops-in-Wine was an old name used, I think, in Queen Elizabeth's time, and July-flowers. The Blue Cornflower (Cyanus) has also been a complete failure with me this year, which I much regret, as I am as fond of them as ever German Emperor was. They are called Bluebottles, and Blawort or Blaver was an old Scotch name for them. My Queen Anne Herbalist discourses delightfully upon these flowers, saying, "their colours are manifold, and very variable; some of a sad or light Purple, or of an overworn Purple, besides Blew"; and says further, "it is found in Fields of Wheat, Rye and Barley, but is also sown in Gardens, which the skilful artist by looking after makes to become of other colors, as in the Description thereof is declared. As to virtues they are many ; it is particularly praised as resisting Poyson, and is recommended for inflamed Eyes." An Eyewater made of Blewflowers and Rye Dough distilled is declared " to clear, strengthen, and preserve Eyesight especially of old People, for which reason some are pleased to call it Break-Spectacle Water; for that those who use it need never come to the use of Spectacles." Eau de Casselunette was once much esteemed in France.

I found last year that the variegated Cornflowers looked especially pretty on the dinner-table by candlelight, far prettier than in the daytime; they reminded one of Dresden China flowers; there was something quite unique about them in candlelight. There is a tiny Blue Cyanus which is very pretty, especially when in seed; its 2I8 


\section{Midsummer to Michaelmas}

little brown bottles full of seed are so quaint. They look like the brown water-gourds the Provençal shepherds carry. Ragged Ladies was an American name for them. My Sweet Sultans, or Basket-flowers, too, are backward. Their virtues, according to the Herbal, seem the same as the Cornflower, but they are given the delightful names of the Turkey Blewbottle, the Turkey Sweet-scented Blewbottle, and Sultan's Flower, "because the Grand Senior espying it, as he was walking abroad, liked it, and wore it himself, for which reason his Vassals held it in great esteem." Parkinson gives this flower the following quaint praise : "This Flower is of so exceeding a sweet scent, that it surpasses the best Civet that is." The Poppies are out now. I do think they are such pretty flowers, so gay! There is nothing prettier than a field of blood-red Poppies such as you may so often see in Devonshire, or in Suffolk, called "Poppyland." I am afraid it is a sign of bad farming; at least so I was told. I recollect once sneaking into a neighbour's Cornfield, where the Poppies grew thick, and surreptitiously planting some Blue Cornflowers, hoping thus to introduce a further beauty which did not seem to be present. Poppy-fields do not seem very common hereabouts, and Blue Cornflowers are rare. I remember, on the Rhine, fields quite blue with Kornblümen, like azure seas when ruffled by the winds. An old name for the Poppy, both here and about Wooler, on the "English side," is " Thunder and Lightning Flower," from an idea that if picked, and the petals fall, the person who had picked the flower would be liable to be struck by lightning. The Poppy was used sometimes as a lovecharm. My Larkspurs (Larksheels, as Shakespeare calls them) are a great success, especially the Hyacinth-flowered one. Knight's Spur it is also sometimes called. Pied d'Alouette is the French name. Lark's-claw is an old English name. Sweet Williams are in beauty now. Sweet Johns is an old name for them, and "London Tufts." Sweet William, some authorities say, is a corruption of "Saintsweetwilliam," but what particular St. William 


\section{Stray Leaves from a Border Garden}

seems rather doubtful. I daresay, in the South, Sweet Williams may be out in full beauty on St. William's Day (June 25), but scarcely here. They were sometimes called, too, Painted Ladies. As to virtues, I don't find they are credited with any. My Herbalist says, "They only serve as Ornaments for gardens." Still as such they are very effective, "and are worthy the Respect of the Greatest Ladies who are Lovers of Flowers." An old name for the Ragged Robin (Flos cuculi) is Wild William, Crow-flower, or Marshflower. Nor has this pretty little wanderer apparently any virtues either, beyond the gift of beauty, which it certainly has when in masses in marshy ground. Robinet déchiré is the quaint French name, Robinet being used as we would say Hodge. St. John's-wort is looking lovely; Grace of God and Rose of Sharon it is called also, and "Aaron's-blood," I suppose, from the red on the leaves, which are sometimes said to be the blood-drops of St. John the Baptist. It is said to be a charm against witchcraft, whereas it was sometimes called "Drive Devil." Stow says it used to be put over the door for this reason. In Italy and France it was also deemed a similar safeguard. In Holland, if gathered before the sun rose, it was thought to be a preservative against lightning. There is a tiny species wild here, which is very pretty. My purple Swamp Lilies (Funkia) are very elegant, with their delicate purple bells and slender stalks. I have been told that to dream of a Garden means a great joy coming-I think this is rather a nice idea; while a dream of Birds brings friends and fortune. I am going to plant Swamp Lilies on the haugh. I believe they would like the river vicinity better than the Garden-bed. They are certainly flowers to be encouraged.

The Saxons called this the Barn month (Arn monath). It is a pity we do not use this expressive name instead of the Roman one.

Boy and I saw a dear fat Toad in the plantation-walk to-day as we were wending gardenward, Boy dragging his little wooden cart, heavily laden with pot-plants returning to the shelter of the Greenhouse. I should have liked to 


\section{Midsummer to Michaelmas}

take Master Toad along, to give him a situation as AssistantGardener in the Greenhouse, but he was indifferent to Boy's tender apostrophe of him as a Darling Toad and hopped hastily away into the Snowberry hedge. Few people seem to like Toads ; they think they are poisonous, which, I believe, is quite a mistake. Sir Joseph Banks was fond of Toads; there is an old story he was seen sprawling on a lawn kissing a Toad! Toads can be tamed, and are quite nice pets, I have heard. I think it was Dr. Johnson who called Miss Burney once a little Toadling, as a term of endearment. This used to be an old Scotch term of endearment. I do not know if very small brown Toads are always to be found at Sandhurst, but I remember being vastly delighted long ago with finding in a walk by the lake in the grounds of Sandhurst a multitude of tiny Toadlings about the size of Beetles. An old Scotch word for a Toad was Pade, an Anglo-Saxon word really. Podda was Frog in Icelandic, and a Podle was a Tadpole. A Padell was a small leather bag. Certainly a Toad looks very like an old leather pouch, I think. My Blue Thistle is looking very pretty, although, unluckily, I have only the pale-blue kind. I have been told that in Roumania there are sometimes whole acres of the Blue Thistle, which looks like a turquoise sea when the sun shines on it. The Globe Thistle (Echinops) is also very effective in garden and vase. I like the fashion of green glass vases; it becomes some flowers mightily, especially this one.

August 6.-I saw a Squirrel hurrying up a Fir-tree to-day, carrying something in his mouth; he looked so funny! A friend of ours one day saw a mother Squirrel carrying her little one; it had its front paws clasped round Mother Squg's neck. I do wish I had seen it. They are said to eat Mushrooms. I should like to see a Squirrel nibbling round a Mushroom. In very hard winters I think they must gnaw the bark of the trees; at least branches of trees look peeled high up, in places where certainly Rabbits could not get at them. There is a lovely Harrisi White Lily out in the garden to-day, and others coming on. White Lilies are very sacred flowers; they have been dedicated 


\section{Stray Leaves from a Border Garden}

to St. Anthony, St. Barbara, St. Swithin, and St. Margaret, and one species to St. Bruno-alas! too delicate this last to grow with me. The old-fashioned Candidum is often called the Madonna Lily and Mary Lily, and is the Virgin's special flower, often to be seen in pictures, and as Mary's Lily is beloved in Irish gardens. Indeed, it used to be said you could tell a Papist's garden by the White Lilies and an Orangeman's by the bold Orange Lilies sure to be in one corner. Curiously enough, it was sacred in pre-Christian days, being dedicated to Proserpine, Diana and Juno; hence its name of Juno Roses ; while a Hebrew tradition declares that Lilith Adam's first wife wore a wreath of Lilies. Mother Holda or Bertha, the Teutonic Ceres, or Earth Mother, the Moon Goddess, wears a robe stained white with Lily-petals, and carries a Lily in her hand and wears a Lily-wreath when she comes, in her chariot drawn by Ladybirds to bear away the souls of neglected children to her celestial gardens. The red and gold Gaillardias are looking lovely, also the purple and white Stocks, and the white Hyacinth Candicans, or Summer Hyacinths, in a neighbouring garden, but ours are as yet still in bud. These flowers look very well in abundance, set in a row along a yew-hedge or yewen. There is a curious red tinge about the wood of yew when it is cut, as if it were bleeding. A yewen is a thing of beauty. Near here there is an old hedge that has grown into veritable trees; it used to be the boundary of the Lady's garden, but now that has passed away, and it is only a neglected fringe by an old stone-built pigstye, close to the cottages of gardening and stable men. The old trees look so forlorn, with no flowers near except a few tufts of faithful Snowdrops. The copper-coloured Day Lilies (Hemerocallis fulva) are coming out now ; they are much later than the yellow ones and more hardy. I shall try them on the haugh, but the Rabbits are terrible drawbacks to civilisation. The white Jasmine is in full bloom; it is delicious. I wish I had a hedge of it. It is said to be lucky to dream of Roses and Jasmine. 


\section{Midsummer to Michaelmas}

Boy and I have been busy for a long time making Rose-potpourri. Cabbage-roses and pink Damask Roses are the best. Velvet-rose and Moss-rose petals, too, are nice, but not white or yellow, they give a bad colour. The usual receipts for Potpourri given in Ladies' papers, \&c., seem to consist of very expensive materials. This is a comparatively cheap one, which I have found good. "Alternate layers of Rose-leaves and Table-salt (some people say Bay-salt), and 12 oz. Orris-root, 5 oz. Gum-benzoin, 4 oz. of Coriander, I oz. Cinnamon, I oz. Cloves, I oz. Pimento, $\frac{1}{2}$ oz. Tonquin-bean, $\frac{1}{2}$ oz. Ess. Bouquet, 2 oz. Lavender-flowers." You may add Tube-rose petals, Verbena leaves, Thyme, and Marjoram, if you like. Another recipe, in addition to Coriander-seed, Orris, Cinnamon, Cloves, Gum-benzoin, and Bay-salt, says Musk and Storax. (Memo. The Roses must not be wet when gathered.) A third version takes in dried Marigold petals. But I do not see much sense in this last, as they have no nice smell. It is odd that our ancestors, the Saxons, do not seem to have known about liquid scents, though they burnt spices and scented woods, and used to make sort of effigies of birds out of bundles of sweet-smelling herbs, named Cyprusbirds, which were burnt at feasts. Queen Catherine de Medicis and Queen Elizabeth were both very devoted to perfumes. I saw the other day a delightful old round perforated brass box like an apple which opened to allow of smouldering perfume to be put within. I wonder whether this was the ornament called in old Scottish inventories a "pome," probably from the French word pomme? Hippocrates, the ancient Greek physician, declared perfumes were medicines, and is said to have cured nervous diseases with them. Pliny also had a high opinion of scents medicinally, and maintained that as many as thirty ailments were curable by the scent of the Rose, twenty by the Violet, and forty-two by the Iris and by the Mint. In the days of Luther, fires of scented wood and spices were supposed to be efficacious in driving away the Plague, and I have known fires of Rosemary and Myrtle lighted to drive away Cholera-I 


\section{Stray Leaves from a Border Garden}

suppose, on the principle of purifying the air and smothering the Bacilli. Cedar-dust is often burnt nowadays to vanquish an evil smell.

August 2 I.-There are a number of splendid Lilies out now, Harrisi and gorgeous speckled Auratums. There is a delightful Roumanian superstition that the Plague cannot enter any house where there are Lilies in the garden, and a Wallachian tradition declares that the Water-lily will be made guardian at the Gate of Paradise on the Judgment Day, and there judge all the other flowers, deciding which may enter and which are to remain in outer darkness. It is curious that there have been found in mummy explorations in Egypt flower-wreaths, dating about the first century B.C., made of Water-lilies. The Water-lily was the emblem of purity, and it is said the name Susan comes from the ancient name of the Waterlily, Seshen.

It is gloriously bright and beautiful, and hot, but dry, which is telling on the garden. All the flowers, and vegetables too, seem to run up and go off quickly, as they did in Jamaica. The birds, those graceless thieves, are sampling the Apples, so we are making jelly and jam of them. Apple-water, I have heard, is nice; but do not know how to set about making it. I heard of two mysterious American dishes the other day-an Apple-slump and a Pan-dowdy! I wonder how they are made! I fancy something in the nature of an Apple-charlotte. Here is an old receipt for Clear Pipinjelly, as followed by our ancestors 200 years ago: "Take I 4 good Pipins, and throw them into cold water, set them on the Fire till they are dissolved, then strain them, and to a Mutchkin of it put a Pound of double refined Sugar: let it boil very fast, and keep it clean skimmed; then put in it the Juice of 2 Large Lemons as it is boiling, try it on a Plate, and when you find it jellies, it is Enough. You may put a Chopin of Water in it." (A mutchkin is equal to an English pint; I chopin = I quart,) Another recipe advises that rose-water be added; rowan-berries mixed with apples give a fine colour to Apple-jelly. 


\section{Midsummer to Michaelmas}

Rowans can also be made into a jelly by themselves, to be eaten with venison. Very few people, however, like this jelly, as it has a peculiar, rather bitter flavour, though a lovely crimson colour. Here is a good recipe which may be useful some day. "Rowan-jelly: Take I quart of good sound Berries, of a good colour; to these add I Pint Fresh Water. Boil the Water, and crush the Berries with a Wooden Spoon for Choice, for Half an Hour, Strain off carefully, pressing out every drop of Juice. To each Pint allow I lb. best Sugar (of the cane), and the Juice of two Good Lemons, Boil the Jelly, and stir without stopping, till a Drop or two, tried on a Cold Plate, congeals at once. Then Pour into Gallypots, which must be first Warmed. Cover over, and store in a Cool Dry aumrie."

On the moors I have heard that a Pickle is sometimes made of Rowans, and they are also used to decorate dishes in winter time. In Iceland it is said, if an innocent person be wrongfully put to death, a Rowan will spring from his grave. The word Rowan or Roun is said to come from the Danish Röun, or Swedish Rünn, and the Icelandic is Run; Norse Runa, a charm, as it is supposed to keep off evil.

September 9.-The Browallia, or American Forget-me-not, is out now in the border, both blue and white. It is not a very common flower, I think, but is pretty with its dark green leaves and bright blue flowers ; I don't care so much for the white variety. The Gladiolus are in great beauty, splendid pink and scarlet spires; Sword-lilies they are sometimes called here. The Sweetpeas, too, are lovely, but in some gardens almost over. A good recipe for keeping Sweetpeas in bloom late is to nip off any dead flowers at once, not to allow them to form seed-pods.

September I r.-The Asters and Stocks are very pretty still, and many different-coloured Scabious. I used not to be fond of these flowers, but in the Scotch autumn they are of great value for flower-vases. Scabious are delightfully called here "Curly doddies," I suppose from a fancied resemblance to a laddie's curly pow. The children have a little song 


\section{Stray Leaves from a Border Garden}

Curly Doddy, do ma bidding,

Soop (sweep) ma hooss an' shoal (remove) ma widden (confusion).

Children further profess to tell what o'clock it is by twisting the flower-heads round and letting it recover itself. The number of times it twists shows what o'clock it is.

The Irish version is, I believe.

Curl Doddy on the midden

Turn round and do my biddin'.

There is one Scabious called the Mourning Widow, a name which is given in Florence to a little Italian Iris, green and black. A decoction of Scabious is said to make fat people thin, so might find a place on some toilettables I daresay. The white Spur-flower (Valerian) is out in abundance now, also the red variety, and Godetias. How like artificial flowers they look, as if made of satin! Mine have done well this year. Last year they were so pretty! My Summer Hyacinths (Candicans) have been splendid, but are now beginning to go over. Lilium speciosum roseum is looking beautiful; its rose-spreckled petals are simply adorable.

September I 2.- I went to see a beautiful collection of Cactus Dahlias in the Manse-garden to-day-crimson, lemon, flame-coloured and white. The Minister's Sweetpeas were very pretty. $\mathrm{He}$ is a great Gardener.

September 1 4.- Holyrood Day. It is still marked in the Prayer-book as Holy Cross Day. In some places I believe it was the custom to go a-nutting on Holy Cross Day, and any one who omitted to go courted ill-luck, hence it was sometimes called Nutcrack Day. Rain yesterday and rain again to-day. I do not think it will improve our Victoria plums or benefit the tall heavy-flowered Gladiolus. I picked a splendid bloom of Lilium Brownii in the kitchengarden yesterday. I do love Lilies, they are some of my favourite flowers. I am sure, if I had been an old-time Egyptian, I should never have failed to bring Lily-buds to deck the shrine of Osiris.

September I 7.-I saw such a pretty effect in a cottage226 


\section{Midsummer to Michaelmas}

garden to-day-the large-flowered Scarlet Tropæolum climbing up a yew-Flame-flower is such a nice name for it; and Nasturtiums were running riot all over a Thorn-hedge. This is Mushroom time, but, unfortunately, edible Mushrooms are not plentiful here. I sometimes find a few in the field, but not the abundance which generally prevails in fields some six or seven miles from here. But it is not a good year for Mushrooms. I am sorry, as I am fond of Mushrooms. But I can never bring myself to experiment on kinds not commonly eaten, such as Ceps or Blewitts, Puffballs and suchlike, however confidently I am assured by experts they taste like chicken. The Puffballs are called here Devil's Snuffboxes, and Puckfist and Fuzzyballs; in Ireland, Cos a Phooka, or Puck's-foot. Puck is said to be derived from Pogge, or toad, meaning the Devil. Herrick writes of a little Fuzzball pudding for the King of the Fairies. I saw one autumn a gigantic fungus (Lycoperdon giganteum) the size of a large stable-sponge. It had been found by the side of an avenue, and the owner had preserved it under a glass globe and showed it to me as a great curiosity. I was told by a Gamekeeper they are not uncommon in the high moorlands, and sometimes used here for smoking Bees stupid, that the honey may be easily taken. There is a lovely scarlet Mushroom, called Amanita muscaria, which is very common in the Highlands, and which is sometimes found brown instead of red, when it gets eaten by mistake with sad consequences. But I believe it can be so prepared, by being well crushed in salt and vinegar, that it becomes harmless. It is eaten in this way by Russian and Swedish peasants. The wild tribes of Northern Asia buy these Mushrooms dried from Russian traders, and make a sort of intoxicating narcotic drink by preparing them with Willowherb or Whortleberries-Hurtberries as these are called in some parts of England as well as here sometimes. The sort of mad drunkenness produced by this drink seems, so scientific people say, to be the same as the Bersarkar madness of old days in Sweden and Norway. In Switzerland, where they also eat Mushrooms, 


\section{Stray Leaves from a Border Garden}

I remember in the Beech-woods seeing brown and yellow Mushrooms, and being told that one kind was good and the other bad, the difference being in the markings on the underside. But, after all, Cassava-cakes are made from the deadly poisonous Manioc, prepared in what seems to be a similar way to the Russian Mushroom method. And even our well-beloved Potato, should its fruit be cooked instead of its root, would poison us all most effectually. I travelled once in this neighbourhood in company with a distinguished Scotch fungologist who was very anxious to make a convert of me, and was perpetually rushing into the hedges after tempting morsels which he tried to persuade me to swallow, but I never had courage enough.

September 20.-Boy went away to school for the first time to-day. We spent the morning in the Greenhouse, instructing Gardener to take special care of his garden and fill it with Pansies. "There's Pansies, that's for thoughts!" The small man is very partial to Pansies-Pansies, Flower of Love. In the meantime his garden looks rather like an African cemetery, with its blue and white rags tied to sticks, presumably to frighten the birds, but rather suggestive of "Loup-Garou " and "Duppy." But it will be haunted for me by the ghost of my nursery bairn. A boy never comes back the same from school as he went, they say. Well, he is away-he departed this afternoon, hugging a big greenand-red French football, cheery and ready for his plunge into the unknown world, having bid an airy farewell to the little comrades who were wont to share the minnow-fishing in his beloved river. "We twa hae paidlit in the burn" . . .

September $2 \mathrm{I}$.- The last day of Summer! She is gone on the Swallow wings, like little Maia, to the sunny lands. What mischief the late high winds have wrought in the garden, levelling the flowers! Yet one can still glean a basketful if one is not too particular. Farewell Summers and Pentstemons, Japan Anemones, pink and white (how I love them!), Lobelias, Day-lilies, Marigolds, and a few Evening Primroses_-Snapdragons, Snaplions some people call them-and many-coloured Scabious, or " $\mathrm{My}$ 228 


\section{Midsummer to Michaelmas}

Lady's Pincushions," Lady of the Lake, as our American cousins call this pretty flower; Michaelmas Daisies or Starwort, whose old Scotch name is Good-bye Summer, Stocks, and lovely Golden Coreopsis, Pinks, and some glowing Red Geraniums, whose doom will soon be sealed by Jack Frost. I always thought the Geranium was one of the few flowers about which no legends seem to have gathered, till the other day, when I heard the following Mohammedan legend. Mohammed, it is said, once washed his shirt and hung it to dry on a Wild Mallow bush, which afterwards was found to have turned into the plant we now know as the Geranium. I wish I knew its Turkish name. There are also a few late Roses in the garden.

September 25.-We have been very busy packing plants to furnish forth a flower-stall at a bazaar. It is to be held some distance from here, in a small seaport where flowers are at a premium, as the East Coast gales do not allow of much flower-growing in the exposed and wind-swept patches of garden on the cliffs on the outskirts. The Saxons used to call September Gerst monath, or the Barley month, from the old name of Barley, "Gerst." A kind of drink used to be brewed with it, called "barlegh." 


\section{CHAPTER IX}

\section{HARVESTING THE HEDGES}

September 29.-Michaelmas Day. How pretty Michaelmas Daisies are, not merely the common bluish-purple kind, but a pale rose-pink variety I first saw in Auvergne! Starworts the Americans call them, while the Germans say Sternblumen. I heard a Scotch lady call them Farewell Summers, the other day.

September 30.-Our flower-selling was a success. It was curious to see how popular Maidenhair and other Ferns were with most of the buyers, and how the charms of Fuchsias and Geraniums paled before the quiet beauty of Ferns. I had had tiny blue-leaved Aloes sent to me all the way from the South of France, on sale also, but although inspected with interest, yet it was not every one wanting flowers who was bold enough to venture on such outlandish-looking curiosities. "It will be wanting a greenhouse likely; it'll no do for the likes of us," said one would-be purchaser, eyeing the uncanny thing doubtfully. "Oh no," I said, " it will be quite happy in a sunny window." "Ah! but the sun does na come roun' ta ma winner! I maun tak' something that can do wanting the sun." And the poor old wife settled on a tiny green Fern, and carried it off in triumph, probably to some one of the grey dingy houses which stand shoulder to shoulder in the narrow closes of the little windblown town. Cut flowers were in great request, but well-known favourites went off sooner than Begonias and such Greenhouse beauties. Tiny tots came wanting 


\section{Harvesting the Hedges}

posies, and old folks and apparent sweethearts. We could not make them up quick enough, our sprays and buttonholes. Three little girls came together, late in the evening, when they hoped to find things cheaper, "It's aye the time for bargains," I heard one say, and she asked for a penny plant. We had a few very cheap ones, and I provided her with one. "But I want tway!" (two) she said in a little shrill high-pitched voice. I found another, and it then appeared she wished to treat her companions. Maggie and Bella politely demurred, but the small fishermaid was resolute; the coppers, smelling strongly of fish, were duly extracted from a large leather purse, and the three little maids went off, proudly hugging each a small pot-plant, two Aloes, I think, and a Lobelia, for the millionaire treated herself into the bargain! An old woman fell in love with a Mandarin Orange-tree, one of a number-four, I thinkreared expressly for the bazaar by Boy. Pips had been planted and watched, and although a watched pot is proverbially slow to boil, two tiny green twin-leaves at last appeared. These, promoted to tiny pots, and decorated with large cards setting forth their history and antecedents, all sold well, much to Master Redcap's ultimate satisfaction. But the Aloe had its moment of triumph when a gay maiden refused to buy any flowers of me, alleging she had to cycle home and could never carry a plant on a cycle safe home. "Well," said I, " if I produce a plant which will stand such a journey, you will buy it ?" She promised, and before her wondering eyes I took a small Aloe out of its pot and packed it up in a brown-paper parcel ready for tying to her handlebar, and told her how said Aloe had arrived in a like parcel from the South of France. Gerarde chronicles an old, old custom in his day, of hanging Aloes from the ceilings of sitting-rooms, as curiosities, apparently. We should have decorated the flower-stall in this way.

October 5.-After several miserable days of rain and winds, which have brought down the yellowing leaves in thousands all over the policies and parks, we have at last a beautiful day, clear and cold, with lovely blue and yellow hills in the 


\section{Stray Leaves from a Border Garden}

distance, but, alas! a smell of Autumn in the air. The Swallows are thinking wisely of leaving us. I saw a number yesterday sitting meditating on the telegraph-wires, probably deciding which route they were going to take to the sunny South. But perhaps the beauty of the day may induce them to put off their departure. I hope so; I hate to see the Swallows go, to say

$$
\begin{aligned}
& \text { "Good-bye, Swallow, } \\
& \text { Away to the lands } \\
& \text { Where I cannot follow." }
\end{aligned}
$$

Now is the time of "Kirns" or harvest-homes. From every field the stooks are disappearing, and you may see flights of small browny birds-called sometimes "Havocburds" -gleaning after the reapers. When the "kirn," or last handful of corn was cut-an honour eagerly competed for-the kirn used to be cried, three cheers being given on the nearest knowe, and the fateful bundle of corn was tied up into a sort of figure, called by the various names of Kirn Dolly, Kirn Maiden, or Cornbabby. Then the "bandster," as the man was called who bound the sheaves, collected all the reaping-hooks, and proceeded to the mystic ceremony of throwing the hooks, surrounded by all the owners. He threw them skyward, and according to the direction in which the point falls there lies the quarter, north, east, or west, in which the owner of the hook would find work as a reaper in the next harvest to come. If any hook broke in falling, the owner would die before next year, and if one should fall with the point downward into the ground the owner would be married before the "harst" came round again. An extra penny used to be given hereabouts to reapers, called the "Hook-penny." The day generally finished up with a supper in the barn, and merrymaking, with music and dancing, when "Bab at the Bowster "-a curious old dance-was a favourite. It seems somewhat to resemble a figure of the foreign Cotillon, being a cushion laid in the middle of the floor and a lass seated by it. Then a number of lads come forward and 


\section{Harvesting the Hedges}

try to seize the cushion. She resists till the right man comes forward, when he is allowed to kneel on the cushion and claim her for the round dance that follows. Other dances were the "Triumph," a sort of march round, which generally opened the proceedings; and country dances, such as "Sir Roger de Coverley," "Patronella," "Circassian Circle," and Reels, played, however, by the local fiddler. But now, at many of these local dances, Polkas and Valses are the fashion; and at a country christening the other day I heard of a " Pas de Quatre" being performed under the name of "Pardycater." Curiously enough, this dance is said to be a combination of an old Scotch lilt and the old-fashioned Schottische. The dressing, too, like the dancing, has followed after foreign fashions, and the young women are not so picturesque as they used to be, while, although the Kirn Dance still survives as an institution, old Kirn customs are dying out, and soon there will be, I fear, but few left who will know how to dance a Ring dance or "ken a Cornbabby." A steam threshingmachine, called "Puffing Billy," pays periodical visits to all the farms, and a "binder" machine has made good its footing at the Gatehouse Farm, despite the "boycotting" it received from some of the farm-folk, who refused at first to have anything to do with it. Reapers and gleaners are well-nigh visions of the past, and a red-wheeled reapingmachine does the work instead. It is, perhaps, more thorough, but is certainly less picturesque. Tales of horror accompany its progress through the land; of sundry too inquisitive bairns whose members it has swept off, and careless drivers who have come to grief. Reaping and gleaning are not the only customs which have died out. Foresters' corn, which was one of the dues paid yearly by some landowners to others holding superior rights over the same property, is now commuted to money. The Crab-apples are lying thickly under the trees in the lane; they were so pretty, those crooked little trees, in the spring, all covered with waxen bloom! Sometimes the country children gather them to roast at the fire; but, as a rule, no 


\section{Stray Leaves from a Border Garden}

one seems to pick these up but us. Roasted Crabs used to be put in ale in Shakespeare's days; he mentions them several times. I am going to make Crab-apple jelly; it is delicious. An old treatise on Forestry, over two hundred years old, which I much delight in for its quaint remarks, avers that, re the "Virtue of Crab Juice. This Juice is asserted by some to make the strongest and best of cyder, provided the Crabs come off a good soil " (Is the corner of the lane a good soil, I wonder?), " are of a Right Sort, the Liquor artfully made, and a due age given it." Further, "if people knew the virtue of a Crab," says an old doctor, " they would value them more than they do," and proceeds to enumerate the ailments it is supposed to be good for ; but since his wording thereof is like the character of the Crab, of a somewhat coarse description, I will not trouble to note them. We went Elderberrying to-day with a view to Elder-wine, armed each with a hooked stick to pull down the branches; baskets, lined with white paper, and scissors, which last were scarcely needed to cut off the bunches of fruit. The birds, however, had been before us, and some of the ripest bunches had lost a good many berries. It was delightful climbing on the fence picking the sweetsmelling bunches of tiny black berries, the baskets seemed to fill in a minute. The lane was looking lovely, the high hedge all ablaze with the red-berried Hawthorns, greenleaved Elders, and red and yellow Brambles (Ang.-Sax. brembel), and the Ferns in the wayside ditch beginning to turn brown and curl.

I never saw such large red hips as the Roses have in that lane, or such bright-coloured ones. I saw a small child wearing a necklet of them; at a distance it looked like big red beads. I think I will try if these Sweetbriar hips would do to make jelly of, like the hips of Rosa Rugosa, the big Japanese kind out of which one can make the most delicious jelly, looking and tasting somewhat like Guavajelly. I know a garden far away by the Western sea where there is a lovely hedge of Rugosa, and high-heaped baskets of glowing hips are brought in for jelly. And this is my 


\section{Harvesting the Hedges}

friend's recipe for Rose-jelly! "Take off the tops of the hips, cut them into pieces, which put in a preservingpan with just enough water to cover them. Keep boiling and bruising until a soft pulp. Squeeze through a cheesecloth, then pass through a jelly-bag; $x \mathrm{lb}$. sugar to every 2 gills of juice; boil 20 to 3 o minutes." I have heard that in France there is a mixture called Conserve de Cynombodons, made by mixing Dog-rose hips deprived of their seeds with icing sugar, I part hips to 2 parts sugar. They are beaten to a pulp, rubbed through a sieve, and then thoroughly mixed with the sugar. I think in America a little honey is added as well. It is a good cure for Aphtha.

The abundance of hips and haws is said to presage a hard winter-" Mony haws, mony snaws"; and another sign is when the Onions have their coats thin :

Onion skin very thin,
Mild winter coming in
Onion skin thick and rough,
Coming winter cold and rough.

Certainly this year their skins are few and thin. There is a saying on the Border that Onions keep off the Plague by attracting its virus to themselves; and I have heard that long ago, when the Plague was rife in any Border village, men were told off to parade around bearing Onions on the points of spears, to attract away the malaria. When the Onions became black, they were thought to have done the business, and were then solemnly buried in a corner of the Kirkyard. I believe there was long to be seen in Chirnside churchyard a flat stone beneath which report declared the Plague lay buried, and woe be to the man who should disturb it. The memory of this seems, however, to have died out. My researches to locate it have been vain. Leyden writes of just such a Plague tombstone:

Mark, in yon vale a solitary stone,

Shunned by the swain, with loathsome weeds o'ergrown,

The yellow stonecrop shoots from every pore,

With scaly sapless lichens crusted o'er: 


\section{Stray Leaves from a Border Garden}

Beneath the base, where starving hemlocks creep, The yellow pestilence is buried deep.

It was sometimes called the Bad Yellow, and tradition has instances of infected people being buried alive by their frightened neighbours. The following is an old weird rhyme once current in the Merse concerning a place now rebuilt, and not very far from here :
Howburn stands its lee lane,
Howburn folk are all gane,
The Pest has come by the water doun
An hasna left a soul in the toun,
The nettles grow on the hearthstane,
And long they'll grow ere there again
A house will be seen at Howburn stede,
For a' the folk of Howburn's deid.

This personification of the Plague reminds me that, when the Cholera was rife in Southern France, and the white mist lay thick at night in the streets of many a town, the Provençals whispered fearfully, "C'est la Peste qui couche dans les rues."

There is a Polish fairy tale which has this same idea; a moujik meets a tall gaunt woman clad in a long clinging cloak, who forces him to bear her through all the countryside on his shoulders.

Here is a recipe for Plague-water from my ancient book: "Take Rue, Carduus, Balm, Spear Mint, Wormwood, Penny Royal, Dragon, Marigold Flowers, Angelica and Rosemary, of each two handfuls; cut them small and put them in the Still with Anise seeds, Caraway, and Coriander and Sweet Fennel seeds: then cover them with spirits and distill it off." But though I found the old Recipe-book in the old family home, I did not find a still, so I am unable to test the virtues of this recipe-which matters the less that the Plague has not been heard of on the Border for many a long year.

Our tale of Elderberries not being complete, we set forth again this day. This time we went to a low-lying meadow heyond the river, and unfortunately, to get there, we had to 236 


\section{Harvesting the Hedges}

cross what looked like lovely green grass by the waterside. But, alas,

Things are not always what they seem, Skim-milk masquerades as cream.

We found ourselves in a mire veiled only by the treacherous grass, and sank well in over our shoes, paying dearly for the basketful of rather unripe berries which was all we got on the farther side. I hope our wine will be a success. This is the receipt, one of many I studied, which we followed-Miss Bartlett's. I knew it was good, for I had tasted wine made from it in Yorkshire, according to her mother or grandmother's recipe: "Five quarts water to every gallon of berries. Soak for ro days, at the end of which time strain and boil the liquor for 4 minutes. Three lb. loaf-sugar to every"gallon of wine. Pour the boiling wine on the sugar and stir well. To every 4 gallons of wine allow $\frac{1}{2}$ oz. whole allspice and $\frac{1}{4} \mathrm{oz}$. cloves, $3 \mathrm{oz}$. whole ginger, bruised. When the wine is nearly cold, stir into it 2 tablespoonfuls of brewer's yeast. Put the spice and the ginger into small muslin bags, tie a piece of string to them so as to keep it outside the bunghole, keep the barrel well filled until the wine has done working, but don't be surprised if it does not begin to work for a few days. When finished working cork down." An older recipe advises the addition of a bottle of Mountain Wine!

It is a splendid cure for colds, taken hot with sugar and boiling water. But there are those who say they prefer a good Whisky Toddy. I do not think people seem to make Elderberry-wine much now about here, though there is a tradition Elder-wine was brewed here in the days of "the old Colonel." And before that even, folks must have made Elderflower-wine, since in Lady Nairne's song of "The Laird of Cockpen" "Mistress Jean she was making the Elderflower-wine" when the Laird in his well-powdered wig came so untowardly a-courting. These are the curious little details which make things real to one. I know an old Scotch house where the ivy-covered turrets are still called the 


\section{Stray Leaves from a Border Garden}

"powdering closets" by an ancient dame of my acquaintance, who remembers driving to Edinburgh in the family coach, and it is easy to imagine the Laird of Cockpen setting forth in his blue coat and cocked hat from just such an old house. There is an amusing story told of the man who was Laird of Cockpen in the days of the Stuarts, that during the prince's weary exile in Holland he used to help Prince Charles to while away the time by playing and singing old Scots songs to him, among others one called "Brose and Butter," which tune I have by me in an old music-book. After the Restoration, Cockpen went back to Scotland to find, like many another loyalist, his estates attainted. Having tried in vain to get them back, he at last went to London, where at first he had no better success. Finally, being unable to get an audience of Charles II., he bribed the organist of the King's chapel to let him take the service one day. At the end of it, Charles not having appeared to notice any change of organist, Cockpen in despair struck up "Brose and Butter" as a voluntary! The King's attention was caught, he rushed to the organ-loft, and nearly fell over the regular organist, who protested in fear and trembling he was not to blame. "You," cried the King, "you could never play anything like it in your life. Odds fish, Cockpen, I thought you would have made me dance." To which Cockpen replied he had no heart for dancing now that he was bereft of bonny Cockpen. "You shall dance," cried Charles; "you shall dance and be Laird of Cockpen yet." And the attainder was at once reversed.

Elderflower-wine used to be made in Ireland; my mother remembers tasting it in her youth, and says it somewhat resembled Sauterne. In the old Herbals an infusion of Elder-flowers is recommended as a pleasant drink, and may possibly be the same. In a curious old treatise on Forestry, over two hundred years old, by a Mr. William Ellis, he says of the Elder: "All Authors that have wrote of the Virtue of Elder agrees, that this Tree is of a General Good to Mankind, in the Liquor of its Berries, in its Rinds, and in its Leaves; insomuch that I have heard it said if any one Tree 238 


\section{Harvesting the Hedges}

deserves the Regard of Men, this does, for its many Galenical salubrious Uses ; and particularly (if Report is true) for its being a very good Drink in an Asthma. And as the red sort is now become so common as to be sold in its juice at the London Markets, I do not doubt but this, in a little time, will also become more universal, and be entertained as a most delicate, wholesome pleasant Liquor at the greatest Tables, even to supplant in some Measure the excessive use of Tartareous Wines." Alas, for Mr. Ellis' sanguine prediction, the making of Elder-wine would seem to have died out. Elder-vinegar, made with I 2 parts vinegar to I part dried flowers, and mixed with honey and water, is said to be a good gargle for sore-throats. It has to be macerated for a few days, clarified with milk and filtered.

The popularity of the Elder in England as a useful oldwives medicine would surely seem to have come down to us from our Danish forebears, since in Denmark to this day Elder-tea, an infusion of the flowers in hot water, is used in cases of chill, called Flieder Thee, as in Hans Andersen's pretty story of "The Elder-tree Mother." The Elder was called Holinnder baŭm in Germany, because it was sacred to Holda, the Goddess of Love ; it was also deemed sovereign against witches. This belief also prevailed in Norway and Denmark. In Germany, after early night frosts have sweetened the berries, a spirit is distilled from them. Linen can be, it is said, dyed brown with Elderberry juice. Birds are fond of the berries and take their tithe of this highway harvest, but I believe they are reckoned poison for chickens. Danewort or Danesblood was a North-country name for the Dwarf Elder, called Zwerg Elder in Germany ; and there was a widespread belief that wherever Danes had been slain it sprang up from their blood; something like the Poppies, which, so the story goes, grew on the field of Waterloo from the blood of the English redcoats slain. In Russia a branch of Elder is said to keep off evil spirits. In France, a layer of the flowers among Apples is said to give the fruit a pleasant savour. A tea or tisane is made of dried Elder-flowers and 


\section{Stray Leaves from a Border Garden}

considered sovereign as an eyewash, or as a gargle for sorethroat. If one can have enough flowers, they are a very pleasant addition to a bran-bath, so often recommended by French doctors as most soothing for nervousness or irritability of the skin.

I believe there is an Elderberry-water made in England, according to The Garden, by crushing the berries and pouring boiling water on them, leaving them covered closely for two or three hours. This water will not come out as clear as that bought in a shop, but that is only because it is not distilled, and otherwise it is quite as good, though perhaps it may not keep as long. The fresh flowers, with fresh lard poured on them boiling hot and strained, make a delicious healing ointment.

Bour-tree is a Scotch name for the Elder. There was an old belief that any baptized person anointing their eyes with the juice of the bark of the Elder could then see witches-a reason, perhaps, for witches disliking Elder. They were said to be a very powerful antidote to witches' spells, a belief which also prevailed in Germany. There is a village called Auchencrow, not far from here, which was noted in olden days for witches, and the Kailyards used to be full of old Elders.

True Thomas, the Rhymer of Ercildoune, or Earlston as it is now called, prophesied under an Elder-tree called the Eildon-tree, though some say it was a Thorn. The remains of his tower may be seen from the railway, a bit of wall covered with ivy, recently saved by an antiquarian society from destruction by some of the local Goths, who have no respect for old-time relics. There is a Border tradition of a shepherd who met on the hills an old man, presumably the Rhymer, who led him into the heart of the Triple Hills, where he found the Knights of the Round Table sleeping each side by side with his steed, awaiting King Arthur's return from Fairyland. Eildon is from the Icelandic eldr, fire. An old Scotch word for fuel is "elden." Watch-fires used to be lit on the peaks of the Eildons in old days. There are many Elder-trees along the banks of 240 


\section{Harvesting the Hedges}

Tweed. Boys used to make popguns by boring Eldertwigs hollow.

In Wales there was a curious fashion of staining flagstones in farmhouses dark green with Elder-leaves dividing the flags diagonally, so that one half is white and one green. It looked well and was said to last a long time. The Snowberry-hedge is beginning to get white with berries, and the Holly-trees are beautifully red. A Robin sings continually in the old Holly by Boy's window, the little Autumn singer who never deserts us, let Winter pinch as sore as may be- "chaunting litel sylvan bard," as Allan Ramsay delightfully calls him, warning us, according to the old song, "to get frese coates, for winter draweth nere." Robins, besides being friendly, seem creatures of habit. I know a Robin who for some winters has frequented a friend's sitting-room, flying about in the room most tamely, and in the spring going outside again. They would also seem to have good memories, as I was told the other day of a gentleman who made friends with a Robin, feeding it, and seeing it continually for several months. $\mathrm{He}$ then went away and did not revisit the place for, I think, two years. But when he did he saw the Robin, who at once came and ate out of his hand as usual! They are the tamest of birds ; if one is working in the garden, one is never at work long before a Robin appears and hops round about, watching with his little bright inquisitive eye. They are so pretty, with their ruddy breasts too!-the Ruddock, as Shakespeare, Spenser, and Bewick call him, the old AngloSaxon term, rudduc, meaning the "little red one." It is a quaint legend which chronicles that his breast is red because it is scorched by the flames of hell, whither he flies every day with a drop of water in his beak, in hopes of putting them out. Hurdis, whose poetry about birds is so pretty, describes him as a "feathery mendicant made bold by want, whose every little action asks aloud alms the most indigent might well afford-a drop of water and a crumb of bread." How pretty the Golden-rod is now in the Manse-garden! I must get some into mine. It is an old-fashioned flower few people 


\section{Stray Leaves from a Border Garden}

seem to know. It was anciently called Solidago Sarracenica, because it was said to have been brought home by the Christians from the Saracen wars. Verge d'or the French call it; it is common in Auvergne gardens, and I have been told grows freely in islands of the Rhone, where it must look very pretty with its feathery golden tufts of flowers. Gerarde praises it as a cure for wounds.

$\mathrm{I}$ am very busy bringing in from the border pet Geraniums which I cannot bear to abandon to the tender mercies of Jack Frost, and collecting my winter bouquets of everlasting flowers, Moonwort and Cape Gooseberry sprays. There is a Giant Physalis Alkenzi I really must get-Franchetti, I think it is called. My "Redbreast-flower" is not the kind of Cape Gooseberry out of which the delicious preserve is made, though many people wrongly think it is; that kind will only grow in Greenhouses in this country. I hang my sprays up to dry under the portico at the back. Now is the time, too, for drying sweet pot-herbs-nose-herbs as some old Herbalist quaintly calls them ; Kŭchengewachs, as the Germans say. I have decorated the kitchen with bunches of Marjoram, Basil, Burnet, \&c., in white muslin bags, and even surreptitiously introduced a bundle or two into the parlour, the way into which is not up a winding stair, but, luckily for me, on the ground-floor, though the windows are, so to speak, first-floor, owing to the different levels of house and front garden. It already smells strongly of the Lavender I have been tying in bunches to put in the napery press. I wish a washerwoman were still called a Lavender, as in old Scotch days. In some old royal account book there was mention of King James' Lavender, meaning the woman who washed his clothes. There is rather a nice plant, called Santoline, or Woolly-leaved Lavender, Cotton Lavender, I must get. Here is a nice recipe for Lavenderwater: "Rub the Lavender from its stalks and pour over it boiling water, then stand it in a hot place to infuse. Next day strain off the water through a muslin. Remove any oil with a bit of clean blotting-paper. Bottle and cork tightly." Of course the colour will not be as good as 


\section{Harvesting the Hedges}

boughten Lavender-water, but it is said to be as good perfume.

I am very fond of Marjoram too, and I agree with Boy in loving Mint. There is a Greek Folk-song which says "the rose is sleeping beside the Marjoram ; my little child is sleeping by his sweet mother's side in a silver cradle." In Greece and Rome young married couples were crowned with wreaths of Marjoram. The virtues of Marjoram are many: the Spirit of Marjoram "comforts the Heart and cheers the Spirit," while a cataplasm of the Green Leaves, beat up with Honey, takes away the "black and blew marks of Blows, Bruises, Pinchings, and the like."

I have several delightful old recipes_- " recippys," as an old woman of my acquaintance used to call them-for Aromatic Vinegar, made with Rosemary-tips and Queen of Hungarywater, immortalised by Perrault as the water wherewith her maids tried to revive the Sleeping Beauty after she pricked her hand with the spindle and swooned. But, alas! they cannot be easilyand inexpensively compounded, as in our grandmothers' days. Proof-spirit, which enters so largely into their composition, has disappeared from mansion-houses along with its still-rooms and stillroommaids, and, in these days of Rimmel and Atkinson's world-renowned perfumes, perhaps it does not matter so much.

Mint is a very nice vegetable, I think, as it looks so flowerlike. Parkinson says of it that soldiers should not use it, because it would abate their animosity and courage to fight. I have a cherished wildling of variegated Cat Mint in a corner of the Rose-garden, but I cannot do as Boy would have me do, and put bunches of Sage in the beau-pots; it is too reminiscent of Roast Duck; but as a tiny hedge-flower it is beautiful. The old Scotch word for a garden of Herbs was a Herbere-II suppose, from the Latin Herbarium. I have a little square patch of Herbere with rows of Basil, Burnet, Marjoram, Herb of Grace, Savory, Lavender, Mint, and Thyme, and Sage and Borage. How pretty a row of Sage is all a-growing, all a-blowing, and Borage, with its lang nebbit flowers! No wonder our fathers 


\section{Stray Leaves from a Border Garden}

liked it in claret-cup, since it professes to "cheer the Heart and expell Melancholy." I have Lavender in many places, in little hedges. I love it so! There is a little garden-path by a Violet-bed, bordered with red tiles, with a tiny Lavender and Rosemary hedge on either side of it, close to a row of white Valerian-Rosmarine, as Spenser calls it. Rosmarine, which means "the flower that loves the seaspray," was a favourite flower in old love-charms, and baths of Rosemarywater were supposed to keep people young. It used to be made into a tea by old wives, and considered a fine remedy in some illnesses. It was sometimes called "Old Man," but why I do not know. In Sicily 'tis said the Fairies love it, and the young Fairies, disguised as snakes, hide in its branches. It used sometimes to be grown as a climber. I think I must try this. Hentzner writes in 1598 he saw it grown thus at Hampton Court, but I do not remember it thus there. There is a quaint old saying that wherever Rosemary does well the Mistress rules. Here I have tried in vain to establish it ; there was none when I came here, and only now one small bush is growing. It is not so common in gardens as it used to be, probably. because housewives no longer believe in its virtues as a preventive of moth in their wardrobes, whence its old name of Guardrobe, or because it is no longer in request for either bridals or burials. It was mostly a death-flower, I think, in the eyes of old England, but was used also in love-charms. It is good as a hairwash, and also pleasant to burn as a remedy against mosquitoes, but such wholesale use is only possible in the South of France, where it grows wild in abundance and becomes almost a tree. An old French name for Rosemary was Incensier - Incensewort as it is sometimes called in the old Herbals. If Rosemary-flowers, says an old Herbalist, are taken all the while it is flowering, every morning fasting, along with bread and salt, they will clear dim eyesight. In Tuscany a sprig of Rosemary was supposed to avert the Jettaiura or Evil Eye. This superstition of the evil eye seems widespread: in Scotland the expression is the "ill e'e," and the Devil is sometimes called the Ill Man; while to bring bad luck on 


\section{Harvesting the Hedges}

a person by means of spells was to cast ill on one or illwish them.

In Fife the expression is to be "yelder-eyed," meaning to have an unlucky eye; and it is further said that, if you meet such a person on starting on a journey, you will have ill-luck. "Yelder" means literally "yellow." It is curious how yellow seems to be deemed an evil colour, witches being said to be partial to it. In Wiltshire and Devonshire there is still a belief in the evil eye and in ill-wishing. In Italy, I believe it is considered unlucky to praise a child's beauty, lest you bring it within the power of the evil eye. I think this same belief is to be met with among Arabs and Hindoos. In Algeria the peasantry think, if a child is kept dirty, it is efficaciously protected against the evil eye. In some parts of Southern France and Italy the making of a certain sign thus, folding in all the fingers except the thumb, first and last fingers, and pointing the hand at a person, is sufficient to infuriate them, as, although this sign is supposed to ward off the evil eye, the person you suspect of being a Jettatore must on no account see you make it. Little coral hands in this shape are often worn as amulets. In excuse for the popular belief that President Carnot had the evil eye, it is curious that once, when he went to Fontainebleau, fire broke out, and when he visited Savoy, a river overflowed and did much damage. One of the Popes was credited with having the same power, and it is curious it was a very good Pope--I think, Pio Nono. It is said that a person afflicted with an "ill e'e" need not necessarily wish to bring evil on others, and may indeed be a most amiable person.

While the Saxons called October the Wine Month and Winter fylleth, from the fall of the leaf, November was very appropriately termed the Wind Month, and sometimes the Blood Month, or Blot monath, because cattle were slaughtered for sacrifice and winter provisions. It used to be called killing time in America.

November. - The equinoctial gales have begun. They say those at sea are to be pitied, but sometimes I think those on 


\section{Stray Leaves from a Border Garden}

shore are in equal danger, when the trees bend and sway like rushes, and great limbs snap like matches, and come crashing down. I saw to-day a terrific sight. Standing in the bay-window of my beloved Winter Parlour, I actually saw the dear old ivied Beech, who always looked so steadfast in his might, bend, waver, and fall right over towards me! It looked just as if it was going to fall on the house. I shrieked, and even as I did so it crashed down, a mighty wreck, just short of the house, prone on the laurel-covered bank, with its branched top right into the Rose-garden! Our view has been so obscured with tree hitherto, it has left such a gap, it seems as if a curtain had been drawn aside. I feel positively chilled as I look abroad, over the wide stretch of brown fields right away to the Cheviots.

I went down afterwards for a nearer view; the giant was a sad sight lying prostrate. From the wretched remnant of the burly trunk still upstanding fluttered a few rags of ivy, but I saw no Squirrels or Owls about, though a Squirrel's old nest was found later, in amongst the upper branches. I hope the poor woodlanders were all out for the day when the catastrophe happened. I never saw anything like the thickness of the ivy stem; it was like a great boa-constrictor wound round the trunk of the Beech. A woodman was sent for, and we have been very busy dividing up the wreck so as to clear the poor Lily-garden, which at present looks like the picture in the old children's storybook of Jack's garden when the beanstalk came crashing down with the giant's weight. Luckily there are no flowers yet above ground to be the worse of the encumbrance which litters the dear little garden, though in the plantation the Snowdrops are already showing tiny little teeth among the dead leaves. I gathered a lovely bunch of French Marigolds today, looking like golden stars in the flowerless border. There are a few flowers still in the Pansy-bed, and if I could bring myself to rob the forlorn-looking bare garden I might pick a bouquet of white Spur-flowers. I have just been planting a number of Acorns, which I hope will grow. I want to try having a bed of Geraniums with a border of tiny 


\section{Harvesting the Hedges}

Oak-trees pegged down. I think it will be very pretty. It is very amusing to grow Acorns in a pot; the miniature Oak-trees are so lovesome! The weather is still wonderfully open for the time of year. In the Orkneys people call the fair weather that comes at St. Martin's Day "Peerie summer," or the "little summer," a rather nice name. I saw a ploughing competition going on the other day in a big field by the highway; at least thirty teams of handsome brown horses with beribboned trappings were at work in successive furrows, while their respective carts stood in a sort of laager by the gate. There are such handsome gateways here, of large grey slabs of stone, generally green and orange with age, and tiny lichens, the top sometimes one entire rounded stone. I saw a rather curious sight to-day when out walking, which neither I nor my companion had ever seen before: two large turkeys were standing on the very top of a haystack in a farmyard, while the rest of the Christmas flock were picking about below. The big black birds looked so top-heavy and out of place. At every turn now one is reminded that Summer's short hour is over, and Winter, dour cold Winter, is at hand. Now that the hedges are so bare, the empty deserted birds'-nests are very visible, and look so deplorable. When they happen to be in or near the Wild Rose bushes, it is said they are often found full of the seeds of the Rosehips. Reason why: the Fieldmice climb after the hips, and then camp in the empty nests to enjoy their spoil! How I should like to see them doing this! Fieldmice are such dear little creatures; I startled one in the Cornfield the other day, almost under my feet; it had such a cunning little beady eye, and looked so sweet as it fled away among the stalks! One needs consolation now, I think, for the disappearance of the flowers to keep house, as George Herbert so charmingly puts it, in the earth :

Flowers depart

To see their mother root, when they have blown, Where they together,

All the hard weather,

Dead to the world, keep house unknown, 


\section{Stray Leaves from a Border Garden}

I find my consolation in the preserving-pan; the "pan is ere " for all:ills, as an old Cook once defined " panacea." I am making a delightful pickle of tiny Onions and Nasturtium fruit. It is improved by one or two Capsicums. Cook and I have been trying to preserve the Wild Rose-hips according to the West-country recipe, and we have produced a very nice syrup. But real jelly we cannot get, owing, I think, to the fruit being over-ripe. Our Rose-hips were particularly fine, being the fruit of a hybrid between Dog-rose and Sweetbriar. One must not use Sweetbriar-hips, as they are covered with fine thorns, which might go through the straining-cloth. Our Crab-apple jelly is a great success, tasting delicious and looking lovely, a clear pink topaz. Crab-apples are said to be particularly good for Cider. My young Japanese Wineberry plants bore well, but, alas, the birds took all the fruit before I remembered to gather it. It makes a delicious preserve, rather like Raspberry. I have heard of a cross between Blackberry and Raspberry, called Loganberry, which is said to be very good. I do not think this is a very good country for Blackberries-Brambles, as they are called here, the name Blackberry being often given to the Blackcurrant. Brummelberries, Blackbowours, and Bummelkites are old names hereabouts for Blackberries; in Roxburghshire, I believe, the name is "Ladies'-garters." In Teviotdale it is the same almost, being "Lady Gartenberries, and elsewhere in Scotland "Drumliedroits" and " Gaitberry." In Sweden it is Jungfrubaar, or Young Lady'sberry, and the Virgin Mary's-berry, and Bromboer. The German name is Brombeere, and the Dutch Braamen. In the West of Scotland it is Blackboyds. In the South of France the children won't touch Blackberries, but say they are poisonous. There is an English belief that on September 29 (Michaelmas Day) the devil puts his foot on the blackberry-bushes, and whoever picks the fruit after that date will be unlucky. This belief used to be prevalent in Scotland, with the variation, "Auld Hornie throws his cloak over the Blackberries"; while in Ireland "'tis himself drags the tail of his coat over them." In Devonshire the- 


\section{Harvesting the Hedges}

village children would never offer Blackberries for sale after the end of September, alleging they became poisonous then. The Saxons called Blackberries "Bramble-apples." Raspberries used to be "Hindberries," a name which lingered long here, but seems now to have given place to "Rasps." Waterton tells a funny legend about the origin of the Bramble. Long ago the Cormorant was a wool merchant, who entered into partnership with the Bat and the Bramble. They freighted a large ship with wool, she was wrecked, and the firm went bankrupt. Ever since, the Cormorant is always diving into the deep in search of the lost ship, the Bat skulks round till midnight to avoid his creditors, while the Bramble catches hold of every passing sheep to try and make up for his loss by stealing wool. The Strawberry-raspberry, which is like a creeping Raspberry in appearance, is said by some people to be worth cultivation, by others not. I have had as yet only flowers. I hear a delicious jelly can be made from the orange-coloured pealike fruit of the Sea Buckthorn (Hippophoe Rhamnoides), very nice to eat with roast meat. But although the Buckthorn, sometimes called Rainberry, grows freely in thickets by the sea not very far from here, I do not hear that the fruit is ever plucked, except by the Hoodie Crows, who soon pick the bushes clean. On a soft grey day, when the sea looked grey, the Buckthorn-bushes grey, with only the abundant berries glowing orange-red, and the distance grey, the scene was a complete Japanese Kakimono, as worked in grey and orange tones of silk.

In India, in the Himalayas, I believe the natives set great store by thickets of Buckthorn; they are communal property, and great gathering parties take place, and jam is made of the fruit. It is one of those strange plants which are male and female, like Ferns and Aucubas. It is curious what a difference the vicinity of the sea seems to make to plants. Only twenty miles away from here I saw the other day a beautiful Arbutus or Strawberry-tree full of flower, though the month is chill November, and Sweet Geranium in open garden-beds in very abundant green leaf, 


\section{Stray Leaves from a Border Garden}

Jasmine nudiflorum and sundry China-roses and a Niphetos on a wall were all in bloom, while in a gardenborder (sheltered, I must admit) were a few lingering pink Carnations and two Azaleas, which the proud owner told me always weathered an outdoor winter. Pernettyas were looking very pretty, all pink berried, in another garden-bed. My poor little garden meantime contains only a few Chinarosebuds, and, of course, the eternal evergreens, of which I get so tired by the end of the long, long winter-" "le deuil de l'étê et lornement de l'hiver," Madame de Staël calls evergreens. 


\section{CHAPTER X}

VISIONS AND RUMOURS OF WAR

THERE is a weird melancholy about these grey Autumn days when the Lapwings are wailing over the black furrows and it falls dark so soon. The wind whistles drearily down the paths, all littered with dry leaves and broken branches. I hate coming home-like Kilmeny-late, late in the gloaming, as I sometimes have to do over the lonely muirland, with those weary Whaups wailing around me, now in front, now behind, and everything looking so different and eerie to what it looks in daylight; even the train appearing a most uncanny and "laidly worm" as it wriggles by in the bottom. There is a rumour a ghost has been seen on one of the unfrequented highways hereaboutsa grim man in armour, who appeared to a country " vet." hastening home late one mirk evening, and nearly frightened him out of his senses. We have never heard of this ghost before. It is suggested, perhaps, he has come because of the war. Yet why a war in South Africa should raise a ghost on the Scottish Border let wiser folk explain ; I give it up, while allowing that our Borderland has many a queer tale, and is an " unked" spot when all's said and done. There is a Hungarian superstition that no ghost dare venture nigh a house where there are Lilies in the garden.

Show me a garden where Lilies grow,

I'll show you a house where no ghost may go,

says the song, so I feel quite safe, since I have the 251 


\section{Stray Leaves from a Border Garden}

garden crammed with Lilies. Sir John Mandeville asserts that our Lord's Crown of Thorns was made of the Albiespyne-that is, White Thorn, what we call the Hawthorn now, and, in consequence, any man who bears a sprig about him is safe in a thunderstorm, and " in the howse that it is ynne may non evil ghost enter." In Ireland and Brittany it is called "Fairy-thorn," and it is deemed unlucky to cut down Thorn-trees. There is a quaint old saying, "No man but has a thornbush nigh his door"; meaning, "No man is exempt from trouble." Further, " this prickly vegetable," saith my old Forester's treatise, is " the greatest security of almost all others to the Farmer and Gardener for preventing the breaking in of Cattel to Fields of Corn, Gardens and Orchards (Pomeries, as was the quaint old Scotch term for orchards); and will resist the Bite and Cropping of all sorts of Beasts. ... And to the Good Housewife it is one of the most necessary Sorts to hang her Linnen on to dry the Greatest Part of the Year, when it is kept Clipped. .... It is also a Shelter and a Refuge for Singing Birds to breed and chant in; and an admirable Sweet Ornament in the Spring season by its fine white Blossom, for a considerable Time."

I believe wine has been made of Haws, but I have not as yet made the experiment myself, or found anybody who has, nor indeed come across any recipe therefor. This is the year for specially fine meteors, prophesied, I believe, thirty years ago to recur about this time. I spent a long time last night at the window watching for meteors. The garden looked so eerie in the odd light of 3 A.M., I felt as if I should not have been surprised to see any number of ghosts come marching along the avenue by the big Firtree. But I saw nothing, not even one falling star. Other people were more lucky, I believe. I remember when I was a child how-the year of the Franco-Prussian Warthe Northern Lights were said to be particularly fine, and current report declared it portended bloody disturbances. There was an old Scotch belief the Streamers or Merry Dancers first appeared before the bloody days of 'I 5 , and 


\section{Visions and Rumours of War}

that the redder they are the warfare foretold will be the more bloody. The Chippewa Indians believe the Northern Lights to be deer rushing by and phantom warriors making merry. There is a superstition peculiar, I believe, to Northern races that the falling of a star means the passing of a soul, while Red Indians call the Milky-way the Pathway of the Ghosts. A meteoric year is said to be a bloody year. Certainly the bloodshed of this present South African War is terrible, enhanced by the apparent small regard paid to the Red Cross flag by the uncivilised Boers. One hears the most pathetic stories of missing husbands and sons; hardly a woman one meets but has a man at the war. Only the other day I heard of a poor woman who has all her seven sons at the front, and there is one in a cottage near here who has three. War-echoes pervade everything. Yet beautiful are the stories of heroism, quiet unmurmuring patience under discomfort, and unselfish devotion to duty. As the soldiers' bard so truly sings :

It's Tommy this and Tommy that and Tommy go away;

But it's thin red line of 'eroes when the band begins to play.

But there are also heroes and heroines in the cottages whence the soldier-laddies come, uncomplaining parents awaiting for news.

\section{THE LAMENT OF THE SOLDIER'S WIDOW}

I cannot see, my eyes are dim, What is it yonder shines?

Is it the sunlight on men's swords And serrièd armèd lines?

Along the sandy highway, Where their hurried feet late passed,

Are those but morning dewdrops On the flowerheads downcast? And, for the beating of my heart, I cannot tell the sound

That now upon the breeze I hear Borne o'er the broken ground.

Is it the sighing of the pines That pierce the distant sky, For all the stormrift branches

In the storm that now sweeps by ? 


\section{Stray Leaves from a Border Garden}

Over the far-off veldt,

Where the shadows lengthening lie,

And clouds are massing darkly,

Do but the wild birds cry?

In many a home Love is waiting, Yearning with tight-claspt hands,

For news of the far-off fighting

Of our men with the Boer bands,

My heart it is sore within me,

What is passing there over the sea,

Where my five brave lads are fighting,

Will they ever come back to me?

The newsboys cry in the darkness,

"Two of our Regiments lost!"

I strained my ears, so deaf to hear, I wondered who paid the cost.

I am blind, I crept to the office, My daughter she led the way,

I wonder how I ever won home; Two were slain on Glencoe's day !

Two sons taken, three sons are left, They tell me three are fighting still-

But even now I may be bereft.

Oh! my youngest, my drummer-boy,

What was it I saw shine?

My eyes are dim, I could not see his face-

One of a thin red line-

Mothers, whose sons are safe at home, Wives, whose husbands are with you yet,

Remember those who have given their all For Crown and country and are bereft.

It seems so curious to remember that it is Summer, and very hot Summer, away out there, and the blood-stained veldts yonder are covered with flowers, dear little Pimpernels, Ox-eye Daisies, blue starry Speedwell and tiny Orchids. There are White Lilies too, and Red Lilies like spots of blood, Heaths, and starry Cinerarias, while the frost lies late on our garden-beds and a few Violets are all I can find, with a miserable pinched China-rosebud or two. I hear the streets of Pretoria are bounded by Rose-hedges in bloom nearly all the year round, and on nearly every Boer's verandah, or stoep as he calls it, great clumps of Gardenia, called Keitje perring, are raised in tubs, while railway cuttings are often thick with Arum Lilies-_ "Pig Lilies" as the Afrikanders call them, which, indeed, are to be seen 


\section{Visions and Rumours of $\mathrm{War}$}

wild by every spruit or burn, as well as Ferns and Hydrangeas. Roses and Tuberoses were thick in my correspondent's backyard. Now, if there is one thing I love, it is a Tuberose with its perfect scent aud stately spire of porcelain flowers. Happily one can raise them here in the most humble of Greenhouses, buying the bulbs for a penny each, and enjoy them without risk of the snake, too often hidden in their graceful tuft of leaves, in their native land.

What a contrast the peaceful tranquillity around here is to the bloody warfare and rumours of wars one hears of daily! The Sparrows are flying in little flocks above the bare hedge, alighting every now and then to sample the Haws. It is so still one can hear the leaves drop. Down on the haugh I see through the bare trees a pair of beautiful grey Herons alight and prepare to fish. In the Rosegarden, where dire devastation has been wrought of late by the Demon Mole, the Mole-catcher, a sturdy individual with satchel and tiny spade like an Irish "loy," is busy laying his snares, probably the last of the season, as there is a whisper of coming snow; but there is no noisy Boy now to inspect and criticise "Auld Moudyman," no rattle of little wooden cart to tell of the coming and going round about the house of little Redcap. I sit alone at the window and think of the days gone by.

The dear old Past is an empty nest,

And the Present the brood that is flown,

says Alfred Austin. But the room is sweet with the scent of the Rose-pourri Boy helped to make. As Shakespeare says,

Flowers distilled, though they with winter meet,

Leese but their show; their substance still lives sweet.

Boy's Canary greets a passing sunbeam with a burst of cheerful song. Yes, I must possess my soul in patience, and remember, as the Indian proverb says, "Mana basanta ki khalaka basanta" (When it is springtime in the heart the whole world is green). Boy is happy elsewhere, and will 


\section{Stray Leaves from a Border Garden}

return when the winter snows are deep. Then Christmas Day is nigh: Christmas Day, that brings scattered members of families together, if only for a day or two, to pick up dropped threads and thrums, and feel once again the old home-spell, which weakens, alas! as we grow older and more worldhardened with our Life's battle.

Christmas Day. - Oh, the joy of the Christmas stocking ! Boy carefully selected last night the very largest stocking in the house to hang at his bed-head and sanguinely trusted that Santa Claus would not fail to fill it. Nor did he, of course. Early this morning I heard the wakeful joyous chirp over his find of my little Bird in his nest, the nest that had been empty so long, where silence that was almost felt brooded unbroken day after day. A mild Spring day; it chanced to be Sunday as well as Christmas Day, so there was service in our little old Kirk, and we wended our way up the brae. In the afternoon Boy and I actually found some Pansies in bud-Flower of Love-in the garden, two Violets -Choice Flower of Delight_-and one Primrose, Harbinger of Spring. "When found, make a note of."

\section{"PATIENCE, THE ANGEL ALL UNKNOWN"}

Patienza, where is he with heart unstirred

By gentle murmur of thine accents, heard

Like some small brook in woodland deep and low

By rustle of thy garments, like a breeze

That sweetest music wakes amid pine-trees.

Which of the sons of men who doth not know

Thine eyes, like stars that in the darkest night

Shine ever brighter, giving forth more light ?

Sister to Sorrow and to Hope thou art, And when before grim Sorrow Joy hath fled Thou comest, Child of Heaven in her stead,

Whispering of Hope to cheer the drooping heart,

Thou art not fair, thou canst not in our eyes

Look fair on earth, but when in Paradise,

Unveiled beside the gate, we meet with thee,

Thou wilt be fair, and in thy mobile face,

The likeness unto Hope we then shall see,

Which upon earth we were too dull to trace.

Twelfth Day.-Boy had his usual little tree, and in spite 256 


\section{Visions and Rumours of War}

of the inclination to snow shown by the weather, his little guests all arrived from the far-away farmsteadings. We had an ultra-military tree, more flags and drums and trumpets somehow than usual, china mugs with generals' heads on them, handkerchiefs with maps and queens' heads; everyone's thoughts are with our soldiers; even in this out-of-theway corner there are those besides ourselves who have kith and kin with the flag.

January 8.-Boy went back to school to-day, driving away down the avenue, chatting gaily to the old friend taking him to the station, with whom he had often wandered round the farm. I watched from the porch to see the last of the golden head. So I learned the lesson all mothers must learn sooner or later-to bear to see the cherished child of home go out into the cold, cold world, lucky if the sun always shine as it has done to-day. Grey skies as a canopy over departures make a heavy heart heavier, I think. Yet, as somebody says, "Good times and bad times and all times win over."

January 20.-Picked a few Snowdrops, scarcely enough, methinks, to deck the altar of St. Fiacre, the tutelary saint of horticulturists.

January 22.-First appearance of Wolfsbane Aconite, dear little woodland fay in his green ruff.

January 23.-The Snowdrop bank is beginning to look quite white, and the Poor Johnnies are peeping out shyly. I picked quite a little bunch of Primroses to-day: it is so delightful to see their "lilye" faces again!

February 3.-Yesterday was a lovely bright day. Every one quoted the old saw, "If Candlemas Day be dry and fair, the half of Winter's to come and mair." To-day sleet and snow, growing worse every minute.

February 14.-The weather has grown wilder and wilder. St. Valentine would need a frieze-coat to-day. There is a foot of snow in the garden, and drifts growing deeper and deeper in many places. Such weather has not been known for nearly thirty years. The trout river is now partially frozen over, and it is most curious to see the miniature snow 


\section{Stray Leaves from a Border Garden}

hummocks and tiny ice-floes with the Water-hens walking daintily about among them. Beautiful long icicles like stalagmites hang from the overhanging banks, and the prettiest glassy drops depend from bough and twig and dry grass-blade. The Rabbits do not like this hard weather, and are sore put to it to find food, barking the Hollies and any other tree they can; they make the most curious tunnels under the snow to and from their burrows. The village school is perforce closed ; the little scholars cannot venture miles from home. Three little girls who lived in cottages close by struggled up the brae to the school and found nothing going on, so, as they told me, "we jist played a wee at marbles in the schule and came oot." The snowplough is busy opening up some of the roads, but some of the country byroads do not receive this attention at the hands of the county authorities, and are in consequence impassable from deep snow-wreaths. In our little village there is such a thirst for war news, the "Laird's twa sons are awa', ye ken." Minister or dominie struggles daily through the fields down to the station in the bottom to learn the news, for the road is blocked with snow; some carters taking sheep to market had actually to cut their way through the snow with spades, and in some places even the snowplough struck work. Yesterday the train had to be preceded on the rails by a snow-plough to enable it to get along at all, and of course it was late. Some people had to spend the night in a snowed-up train not very far from here. Birds are frozen, and I heard of some birds-Sparrows, I think-whose claws were frozen to the branch they sat on, and would have died but for a kind passer-by, who warmed their little feet and freed them. A curious thing has happened in our cold-frame. Some Voles got in and barked my variegated Geraniums. A trap was set, and, strange to say, the Vole who was caught in it was actually found half devoured by his kinsfolk, a thing none of us ever saw before. Yet, in spite of this intense hard weather, I found in a wind-swept clearing under a tree in the "plantin" some Snowdrops in bud. 


\section{Visions and Rumours of War}

February 20.-The water-gate on the river has been carried away by the ice breaking up and coming down in great floes. These blocks have been swept along the haugh, and are now covered with snow. Snow everywhere! For two Sundays we had no service: the congregation could not struggle through the drifts. Yesterday there was a scarcity of baker's bread in the village, as the baker did not " get thro'," and when at last he did appear he drove a pair! We hear the telegraph-wires are broken down near Edinburgh, and for two whole days the capital of the North was cut off from London, and messages had to come round by Ireland. Posts are late, of course. What a weary tramp poor "Posty," the old soldier, has, to be sure!-yet we think we are lucky to get letters at all. But the delay in the transmission of war news is very hard, so many Border-men are at the front. I picked a basketful of Snowdrops where the snow had melted on the banks; it was so curious to see them! A funeral was blocked on the road to the church, and the mourners had to camp in the drift. Altogether the present aspect of things is very like the graphic picture given of Winter in old Bishop Gawain Douglas' rugged verse, rendered intelligible to modern folk by Mr. Warton.

It is curious how these severe Winters seem to recur at intervals. By the way, this ought to have been Leap-year, but it happens to be the one when the leap has to be taken, so now there will not be a Leap-year till I 904, so I shall have to wait till then to inspect the Beanpods and Peascods, to see if the old saying be true, that the Peas and Beans grow reversed in their pods in Leap-year, because it is the Ladies' year, and all things go by contraries.

There was no new moon this February, but two new moons in January and two in March; if it had been a Leap-year there would have been one in February and only one in March. 


\section{CHAPTER XI}

THE WEARING OF THE SHAMROCK AND ROSE

March Io.-I saw such a pretty sight to-day-the hounds in full cry down by the river and up the ploughed field on the other side, with pink coats riding along in the road beyond; the sound of the horn echoed through the clear air, and we watched it all from the plantation, wondering whether the hunt would come our way; the sky was very blue and dappled with white, there were lingering white snow-wreaths along under the hedgerows, while the sun was shining brightly. It was a very pretty and picturesque sight. One day even the huntsman lost the hounds, and when the hunt picked them up again they were hunting in fine style all by themselves and pressing Reynard hard. But he escaped. I think I may admit I was glad, since one should be generous to a foe who struggles gallantly. It is curious that the local prophetic saws about the abundance of haws and thin skin of Onions I noted some months back should have been so speedily and thoroughly verified; it makes me think there is sometimes more truth than people imagine in what are sometimes despised as vulgar fancies about natural things.

March $17 .-$ St. Patrick's Day. Everything white with snow again, but the sun shining brightly. We had in the village school to-day a little show of things of interest connected with the war-the Queen's Chocolate-box presented to Boy's elder brother, sent home for safe keeping; ostrich-eggs, with local flowers painted on them, from Cape Colony, a Puff-adder's skin, fragments of a Boer shell, and even a Boer vrouw's pink cotton sun- 


\section{The Wearing of the Shamrock and Rose}

bonnet! and many other curiosities of odd variety. I think as great a curiosity as any there were the basketsful of Snowdrops, which were gathered literally from under the snow, dried and made up in tiny bouquets, and sold by two dear little village maidens wearing wreaths of Ivy and Snowdrops. When every one in the audience was duly "bunched" the effect was really very pretty. The money raised we send to a poor little trio of tiny children-orphans by the war.

\section{THE STORY OF THE ORPHANS}

Good people, listen now, I pray-

This is the orphans' story,

For whom we're here to-day.

My words are few-

But mark them well-

They are, alas! too true.

"Yet we must tell " . .

The neighbour women whispered,

Round the bed whereon she lay,

Sick unto death, a soldier's wife,

Her husband far away.

"Where was't he fell ?"

" At Magersfontein," some one sadly said ;

Another added softly, " Doing his duty."

"And he is dead"-

The new-born baby wailed,

The mother stirred,

"What news?" she gasped, her lips were dry,

There was a breath as of a general sigh,

And some one told her.

She did not speak, she turned and lay,

Her face unto the wall and passed away.

Those doubly orphaned children wail for bread.

Ye cannot give them mother's love,

Or call their father from amid the dead,

Where, in the far-off veldt they lie

With Wauchope as they fell-face to the foe ;

'Tis thus the Black Watch die.

Think of the little children

Who thus have lost their all-

Remember every little helps, and give

Somewhat, I pray, in answer to this call,

And God, who bless'd the widow's mite,

Nor lets the sparrow fall,

$\mathrm{He}$ will repay. 


\section{Stray Leaves from a Border Garden}

March I9.-How enthusiastically St. Patrick's Day seems to have been kept everywhere this year!- - even those people who were not Irish wore Shamrocks in compliment to the Irish soldiers. Formerlv the Irish soldiers used to get into a scrape if they wore Shamrocks. Now it is the order. I believe this popular change is entirely due to Queen Victoria's graceful tact. It is curious to think it is barely a hundred years since the "wearing of the green" was deemed a treasonable practice in the Emerald Isle, and now, from the Queen to the man in the street, every one wore the Shamrock on the 17 th.

The word Shamrock is said to come from an Arab word, shamrookn, meaning a "club," or "shillelagh," which last, indeed, Irishmen have always been partial to. Old Herbalists sometimes called it "Shaenrog." To find a Four-leaved Shamrock means good luck. Lord Edward FitzGerald and the rest of the United Irishmen should surely now sleep easy in their graves. Shamrock-seed is being sent to South Africa to be planted on the graves of Irish soldiers. It is odd that, although St. Patrick's Day has always been kept in Ireland from time immemorial, it has never been taken much notice of before in London and Edinburgh, but this year London seemed a green city, and every second person met with walking down Princes Street in "Auld Reekie" had a bit of green about them.

March 31.-At last a real Spring day, but cold in the shade, where the hail that fell yesterday lies still unmelted. Primroses (Mayspinks as they used to be called) are coming out all over the banks in the plantation, yellow and pink and purple and white. Outdoor Hyacinths are showing bud. Daffodils in bud too, and Crocuses, like sunrays on the brown earthbeds; last, but not least, dear Satin Lily.

April 6.-Boy came home for his Easter holidays! The following is an amusing charm sometimes practised in Bohemia against Fleas : during Holy Week put a Palmbranch behind a picture of Our Lady, and on Easter Sunday morning take it down and say, "Depart all 262 


\section{The Wearing of the Shamrock and Rose}

animals without bones," and you will have no fleas in the house all the year.

April 7.-Boy very busy gardening, making his little garden pretty with transplanted Primroses, Vesperbells and Daffodils. $\mathrm{He}$ was much delighted to find that some of the Willow branches with which he had fenced in his little parterre are actually budding, having taken root.

April 2 I.-To-day we had rather a pretty little ceremony over the planting of a Red Oak (Quercus coccifera) Bloody Oak as it is sometimes called-in the Lily-garden by the stump of the old Beech, which, by the way, by its rings, was evidently nearly 300 years old.

Boy led a small procession of some half-a-dozen infant villagers up from the garden, through the plantation, marching along with trumpet and drum, bearing little Union Jacks; it looked so pretty, winding along by the riverside, the little girls in blue and pink frocks and white "pinnies," and one tiny golden-haired thing in a sun-bonnet tightly grasping its flag.

We received the procession to the patriotic strains of "Scots wha hae wi' Wallace bled" proceeding from Boy's beloved music-box hidden under the garden-seat. Gardener was in waiting with the young Oak-tree, whose top was gaily decorated with gilt tinsel and red ribbons. Boy solemnly planted it, and then a short speech was made to impress on the children - the men and women of the future-how the Oak had been planted to commemorate the year of the war. After which Boy cried, "Three cheers for the War-tree!" which was followed by a discordant blast of triumph blown on the tin trumpets. A bouquet, I believe, is generally offered to ladies who christen ships or open bazaars. In this case a basket tied with red, white, and blue ribbon, and filled with oranges, was offered to the young Tree-planter, to be divided among the members of the procession, who then formed up and were photographed, rather to the horror of one tiny boy, who began to howl on seeing the camera pointed at him. Boy then led off, beating his drum vigorously, followed by all the children, and very picturesque 


\section{Stray Leaves from a Border Garden}

they looked disappearing among the laurels. There is an old saying, " $\mathrm{He}$ who plants trees loves others besides himself." I think we must make a point of keeping "War-tree Day" every year. In the States I believe "Arbor Day," when trees and shrubs are planted, is of annual observance. I think also in Canada and British Columbia.

April 22.-A lovely Spring day! I saw a Red Admiral Butterfly to-day in the garden-the first I have seen; how pretty they are! Boy and I went after Wild Pansies in the stubblefield this afternoon; we mean to transplant some into his garden, they are so pretty, and also into a little wild garden I am making under an Oak-tree on the haugh, around a tiny mire. I think they are the same kind of bright little Mountain Pansies I remember seeing on the uplands in Auvergne. Herb Constancy is one of the Pansy's pretty old names.

We saw such a pretty scene in the field-the shepherdess feeding some small lambs out of a bottle. The dear little curly things jumped and frisked around her, all trying to reach the milk at once, flirting their long tails the while and butting each other; they were so tame they let Boy pat their curly backs to his great delight. He was much interested when I told him I had once seen a baby lion in a menagerie, and it was all covered with tight curled khaki-coloured wool like a lamb, and was fed similarly out of a bottle. We saw a Bat flying about in the sunlight this afternoon down by the river ; very early for it to be out; at first I thought it was a bird. I think Flittermouse, the old name for a Bat, is nicer than Bat. They say a woman ought never to walk about without a hat or handkerchief on her head when Bats are about, as, should one alight on the hair, it is difficult to disentangle it, and its bite is very sore. It was called the "Bird of Darkness" (Attaleph) by the Hebrews.

I remember being much alarmed once during the night in a Jamaican country house by a large number of Bats which entered the room through the open windows, and 264 


\section{The Wearing of the Shamrock and Rose}

circled round and round the bed; the Mosquito-net canopy, however, being well tucked in, I was not touched by them, though my nervousness at this untoward invasion prevented my having what the Hindoos delightfully term "a golden night"-i.e., a night when one sleeps well! I believe Bats can be tamed, and make interesting pets, but they are very uncanny creatures to look at. In Shakespeare's days there seems to have been practised a sport called Batfowling, generally in the Autumn, when the trees, being leafless, the Bats take refuge in hedges, stray Holly-trees, or in hayricks. They are roused by the beating of sticks about their probable refuges, and then flying forth, flutter round the lanthorn or torches carried by the party of hunters, and are entangled in a net of fine twine fastened between two staves carried outspread behind the light. Bat mammas seem to have a hard time of it, since I believe they make no nests, but carry their young always about, clinging to them.

April 23.--St. George's Day, and also the anniversary of Shakespeare's birth and death. St. George's Day used to be a great holiday with Englishmen in the days when Saints' days were made a welcome excuse for the making merry in which old England delighted. In olden times it was the fashion, I have heard, to wear blue coats on St. George's Day, and the blue Harebell was said to be his flower and wear his colours. It was also customary to wear a Rose, preferably a Red Rose. The "Fighting Fifth" (Northumberland Fusiliers), I believe, have worn a Rose on St. George's Day ever since 1675 ; their badge is St. George and the Dragon, and the united Red and White Rose, lipped, ensigned with the royal crest. I think eleven other English regiments wear similar Roses, while Yorkshire regiments wear the White Rose and the Loyal North Lancashires a Red Rose.

April 24.-The present high tide of interest in sentimental anniversaries has caused St. George's Day to be kept in a way it has not been for years. London positively smelt of Roses, the papers say, yesterday; they were sent in hundreds from the Rose-gardens of Kent, the Garden of 


\section{Stray Leaves from a Border Garden}

England. And the people who were too poor to buy real flowers wore penny paper Roses! Yorkshiremen wore White Roses, and Lancashire folk were supposed to don Red Roses, but not this time in enmity one with another ; and, of course, church-bells were rung and flags hoisted everywhere. There were special services, too, in churches, and in the schools the children were instructed in St. George's history. Even the Queen wore a St. George's Rose as she did a St. Patrick's Cross ; will the present sovereign wear a Thistle on St. Andrew's Day (November 30 )? No one wore Leeks in honour of St. David on March I, but perhaps next year he will be likewise honoured. There is a curious entry in the King's MS. where fifteen shillings is noted as being given to some one who presented a Leek to my Lady's Grace on St. David's Day, my Lady's Grace being the Princess Mary, daughter of Henry VIII.

April 28. - I went by the field to-day and saw all the poor little lambs' tails cut off and lying in a heap on the ground, while Bopeep in her pretty orange-striped petticoat was nowhere to be seen.

Here ends my Note-book. I must get me another for my daily jottings. Pepys said of Evelyn's discourse about gardenage that it would be a most noble and pleasant piece. A most noble piece I cannot expect my little piece of country broidery ever will be, but I hope it may be pleasant to any who may chance to come across it. Anyway, it has given me many a pleasant moment and helped to while away many a dull one. 


\section{CHAPTER XII}

\section{KINSHIP AMONGST FLOWER-NAMES AND BIRD- NAMES, WITH GLOSSARY}

THERE is something to me very interesting in tracing how some marked peculiarity of feature or qualification results in almost synonymous names in different countries. In the following little Glossary I have followed this out, not so perfectly as I could wish, dealing, of course, only with such flowers and birds as I have come across. I think it also curious that some of the flower-names mentioned as common ones of the day in my old Queen Anne Herbal still survive beyond the sea among cultured folk in America; for instance, the garden Orpine is known by Americans as "Live for ever" and "Midsummer men." Names which have died out of usage in the Laird's garden may sometimes be found in the mouth of the hind who, while he will talk of a Daisy to his master, may be heard calling it a Gowan to his bairn in the Kailyard. Names are often synonymous in two or three countries and not in others; for instance, what we call Asters in England are known as Reine Marguerites in France, and as Queen Margarets in America.

Many of the English names given in the following pages are unknown here, but still survive in some counties of England, others are only now to be found in old Herbals. I do not pretend to have herel every flower's many names, but such as struck my fancy. 


\section{FLOWER GLOSSARY}

Aconite. Monkshood, Helnietflower, Friar's-cap, Luckie's Mutch, Wolfsbane.

Greek-Aкоритор.

Latin-Aconitum Napellus.

French-Aconit Napel, Coqueluchon, Madriette, Capuchon de Moine.

Italian-Aconito Nappello, Cappuccio di frate.

Spanish-Aconito Napelo.

German-Blaue Mönchskappe, Stŭrmhüt, Wolfswurz, Eisenhïtlein.

Dutch-Blaauwe Monnikskap, Blaauwe Wolfswortel.

Danish-Blauemŭnke, Mŭnkehætte, Stormhat.

Swedish-Stormhatt.

\section{Adder's-tongue.}

Latin-Ophioglossum.

Italian-Lingua di Serpente.

French-Langue de Serpent, l'Herbe sans Couture, Ophioglosse.

Spanish-Lengua de Sierpe.

Portuguese-Lingua de Serpente.

German-Natterzŭnge, Schlangenzŭnge.

Dutch-Adderstong, Natertong.

\section{Agrimony.}

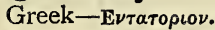

Latin-Agrimonia Eupatoria.

Italian-Agrimonia Eupatorio de' Greci.
Agrimony-continued.

French-Aigremoine, Souheirette. Spanish

Portuguese Agrimonia.

Dutch-Agrimonie, Leverkruid.

German-Ackermennig.

\section{Alchemilla. Dewcup, Ladies'} mantle.

Latin-Alchemilla.

French-Manteau des Dames, Pied de Lion, Alchimille.

Italian-Alch, Piède di Leone.

Spanish-Alquimila, Pie de Leon.

German-Frauen Mautch,Lơwenfŭss, Sinau.

Dutch-Zinauw, Leuwenklauw, Onze (our) vrouve mantel.

Swedish-Dragblad, Mariekapa.

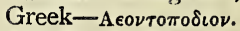

Arabic-Al Kemelyeh.

Anchusa. Alkanet. (This is, I think, a Moorish corruption.) Latin-Anchusa sempervirens.

French-Anchuse.

Spanish-Lengua de buey.

Italian-Ancusa.

Greek-A $\boldsymbol{\nu} \chi v v \sigma \alpha$.

Anemone. Windflower, Woodanemone, Emony, Pasqueflower, Flaw-flower.

Latin - Anemone nemorosa, Herba Venti.

Arabic-Jackick.

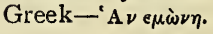




\section{Flower-Names and Bird-Names}

\section{Anemone_continued.}

French - Anémone, Sylvie, Paquette, Fleur de Vendredisaint.

Italian-Anemone.

\section{Angelica.}

Latin-Angelica, Archangelica.

French-Angélique.

German-Engelwürtz, Angelika.

Dutch-Engelwurtel.

Italian

Portuguese Angelica.

Spanish

$\left.\begin{array}{l}\text { Danish } \\ \text { Swedish }\end{array}\right\}$ Angelik.

Arbutus. Strawberry-tree.

Latin-Arbutus unedo.

French-Arbousier.

\section{Arbutus, Creeping. Bear-} berry, Rapperdandies.

Latin-Arbutus, Uva ursi, Vaccinia ursi.

French - Arbousier trainant, Raisin d ours.

Italian--Uva d'orso.

Spanish-Uva de oso.

Portuguese-Uva de urso.

German-Beerentraube, Steinbeere.

Dutch-Beerendruif.

Swedish-Miœlbær.

Danish-Miœlnebær.

Arum, Aron. Cuckowpint, Wake Robin, Parson in the Pulpit, Lords and Ladies, Bulls and Cows, Friar's-cowle, Calvesfoot, Jack in a Pulpit, Our Lord and our Lady, Bloodyman's-finger, Starchwort, Wakepintle.

Latin-Arum maculatum.

French-Arum, Gouet, Pied de Veau.

Italian-Aro, Pie Vitellino.

Greek-A A ov.

Spanish-Aro, Yaro comun.

German-Aron, Aaron's wŭrzel, Kalbsfŭss.

\section{Arum, Aron-continued.}

Dutch-Aron, Kalbsvoet.

Swedish-Aronsart.

Danish-Dansk, Ingefer.

Auricula (Little Ear). Primrose Bear's-ear, Dusty Miller, Tanner's-apron, Cat's-lug (ear), Sanicle, Mountain Cowslip, French Cowslip.

Latin-Auricula ursi, Sanicula alpina.

French-Oreille d'ours.

Spanish-Oreja de oso.

German-Aurikel.

Italian-Orechio d'orso.

Dutch-Beeren ooren.

Berberis. Berberry, Barberry, Guild-tree (meaning the Yellowtree).

Latin-Berberis.

French-Epine vinette.

German-Berberitzen.

Dutch-Berberisse.

Italian-Berbero.

Spanish-Berberis.

Arabic-Berberys.

\section{Betony.}

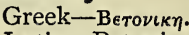

Latin-Betonica.

French-Betoine, Beltête.

Italian-Bettonica.

$\left.\begin{array}{l}\text { Spanish } \\ \text { Portuguese }\end{array}\right\}$ Betonica.

German $\}$ Betonie.

Polish-Bukwika.

Bluebell. Crowtoes, Crowflower, Wild Hyacinth,Jacynth, Gowk's-hose.

Latin-Hyacinthus anglicanus, Scilla nutans.

Italian - Giacinto, Baccara, Lingua di Leone.

Germanl-Hyacinthe.

Spanish-Jacinto.

Dutch-Jacint. 


\section{Stray Leaves from a Border Garden}

Butcher's-broom. Kneeholly, Kneeholm, Prickly Pettigree.

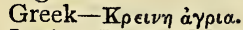

Latin-Ruscus Myrtecantha.

French-Petit Greou (or Little Holly), Houx frelon, Fragon piquant, Petit Houx.

Italian-Rusco, Pungi topi (Prickrats).

Spanish-Brusco.

German-Stechlicher, Mausdorn, Myrtendorn, Mausdornbusch.

Dutch-Muisdoorn.

Bohemian-Lesnj myrtus.

Danish-Musetorn.

Russian-Menschoi myscheitern.

Butterbur. Pestweed, Eldin docken (because the dried leaves used to be used as fuel-elden -from the Icelandic eldr).

Latin-Petasitis vulgaris.

German-Pestilenzwurz.

Spanish-Sombrera.

Campion (Red). Mary's Rose, Gardener's Delight, Rose of Heaven.

Latin-Lychnis.

Italian-Licnide.

French-Oeillet Dieu.

Dutch-Christes eie.

German-Himmelsroschen.

\section{Canary Creeper. Yellow} Birds.

Latin-Tropæolum canariense, or Peregrinum.

Spanish-Pajaritos.

Caraway. Carvy.

Latin-Carum carui.

French-Carvi.

German-Kümmel.

Dutch-Kerwey.

Italian-Carvi.

Spanish-Alcaravea.

Celandine, Lesser. Swallow-wort, Pilewort, Figwort.

Latin - Ranunculus ficaria, Chelidonium minus.
Celandine, Lesser-cont.

Arabian-Memeten.

Italian-Celidonia.

Spanish-Celidueña.

French-Petite chélidoine.

German-Schellkraut.

Cherry. Cherise (Chaucer), Mazzard, Merry.

(Here in Scotland the word Bird Cherry, which more properly belongs to Prunus padus, is sometimes applied to Prunus or Cerasus avium, here also called Gean, Guienne. The French is Guisne and Merisier Guignier.)

Dutch-Karseboom.

Latin-Cerasus.

French-Cerisier.

Spanish-Cerezo.

Portuguese-Cirieja.

Italian-Ciriegio.

German-Kirschbaŭm.

Polish-Wisn.

Bohemian-Wissne.

Turkish-Wischna.

Italian-Visciola.

German-Weichsel.

\section{Cherry, Bird.}

Latin-Prunus padus is more correctly here Hackwood and Hagberry,from the Anglo-Saxon haga, a hedge.

Italian-Amarasche.

Swedish-Hägg.

French-Griottier.

Spanish-Guindal, Garrafa.

\section{Chrysanthemum.}

Latin-Chrysanthemum.

German-Goldblŭme.

Spanish-Crisantemo.

French-Chrysanthème.

Italian-Crisantero.

Clematis. Virgin's - bower, Traveller's - joy, Hedgevines, Old Man's Beard. (It is curious that in Ettrick, Forfar and Fife a traveller is a synonym for a beggar!) Ladies'-bower, Vir- 


\section{Flower-Names and Bird-Names}

\section{Clematis_continued}

gin's - bowerburning, Burning Climer, Smokeweed, Bindwith, Love.

Italian-Clematide, Vincapervinca.

German-Teufelszwirn.

Latin-Clematis.

French-Clématite, Herbe des Gueux.

Coltsfoot. Son afore the Father, Assesfoot, Foalsfoot, Horsehoof, Bullsfoot, Cowheave, Dovedock.

Latin-Filius ante Patrem, Tussi lago farfara.

French--Tussilage, Pas d'Ane, Pas de Poulain.

Italian - Tossilagine, Unghia Cavallina, Farfaro.

Spanish-Tusilago, Una de Asno.

Portuguese-Tussilagem.

German-Huflattich.

Dutch - Hoefflad, Paarden klaauw.

Danish-Hofblad, Hovurt.

Swedish-Hoesthof.

Polish-Podbial.

Russian-Divoje, Listnik.

Columbine. Colombo, Doveplant, Cullambine, Culverwort. (Can these be the Culverkeys Isaak Walton writes of which have baffled so many commentators? I have seen Alpine meadows blue with Colum. bines.)

Latin-Herba Leonis, Aquilegia, Gants.

French-Ancolie, Colombine.

Italian - Aquilegia, Aquileia, Colombina.

Spanish-Paxarilla, Aquilena.

German-Akelei.

Dutch-Akkeley.

Swedish-Orlik.

Polish-Akerlilia.

Russian-Kolokoltschiki.

Japanese-Odamaki.
Comfrey. Lang de beef, Con sound, Boneset, Blackwort.

Latin - Symphytum officinale, Consolide major.

Italian - Consolidu, Orecchio d'asino.

French-Consoude, Langue de Vache, Langue de Bouf.

Spanish-Consolida mayor.

Portuguese-Consolda major.

German - Wallwurz, Schwarzwurz.

Dutch-Waalwurtel.

Danish-Kul sukerod.

Bohemian-Kostiwal.

Swedish -Wallöost.

Polish-Zywokost.

Russian-Solnoi, Koren.

Convolvulus. Nightcaps, Bindweed, Withewind, Hedgebells, Lady's-nightcap.

Latin-Convolvulus arvensis.

French - Liseron, Clochette, Chemise de Notre Dame.

German - Zaunkraut, Windekraut, Zaŭnwinde.

Dutch-Groote Winde.

Italian-Vilucchio, Convolvolo.

Spanish-Campanilla.

Cowslip. Petty Mulleins, Paigle, Palsywort, Key-flower, Herb Peter, Ladies'-fingers, Cow's-mouth, Our Ladys'-keys, Fairy-caps, St. Peter's-wort.

Latin - Primula veris, Herba paralysis.

French - Coucou, Primerolle, Primevere.

Italian - Primavera, Primola, Tasso barbasso.

Spanish - Primavera, Primula, Yerba de San Pablo.

Portuguese-Primavera.

German-Schlüsselblume, Himmelschlüsselchen.

Dutch-Sleutilbloem, Bakkruid.

Danish-Oxedrif.

Swedish-Oxellagg, Orlagga.

Polish-Bukwica, Biala.

Russian-Bukwiza.

Anglo-Saxon-Cuslyppe. 


\section{Stray Leaves from a Border Garden}

Crab-apple. Scrog, Hedgeapple, Scarb-tree (from the Anglo-Saxon scrobb).

Latin-Pyrus malus.

Italian - Tubero, Meluggine azzeruolo.

German-Holzapfel, Hägapfel (Hedge-apple).

Spanish-Manzana, Meladucha.

Cranesbill. Knife and Fork, Birdseye, Stork's-bill, Mountain-flower, Wild Geranium, Heron's - bill, Herb Robert, Robert, Robwort, Death-comequickly, Red Robin, Robinflower (called Herb Robert because it flowers about April 29, St. Robert's Day).

Latin-Geranium Robertianum.

French-Bec: de Grue, Robertin, Herbe Robert, Geranion.

Italian - Geranio Robertiano, Pinzette.

Spanish-Geranio hediondo, Pico de grulla.

German - Storchsnabel, Ruprechtskraut.

Dutch - Robbertskruid, Roode Oijevaarsbek.

Greek-Tepavıov.

Crocus, Autumn. Naked Lady, Orphans, Upstarts, Meadow Saffron.

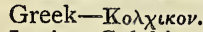

Latin-Colchicum autumnale.

French-Tue-chien,Veilleuse, Safran, Colchique d'automne.

Italian-Colchico, Giglio matto, Strozza cane.

Spanish - Colchico, Villorita, Quitameriendas.

Portuguese-Colchico.

German - Lichtblŭme, Wilde Safran, Herbstblume, Herbstzeitlose, Nackte Jungfer.

Dutch - Tydeloosen, Naakte Vrouwen.

Danish-Nogne Jomfrue.

Polish-Rozsiad, Cimowit.

Swedish - Nakna Jungfrur, Tidlæsa.

Russian-Beswremnoi zwjet.
Crowfoot. Buttercup, Crawtaes, Cat's-clover, Crowtoe (mentioned by Milton), Crowflower (Drayton), Shoes and Stockings, Cat's-claws, Cat in Clover, Fellbloom, Birdsfoot, Eggs and Bacon, Butterjags.

German-Hahnenfuss.

Dutch-Veld Haanevoet.

French-Bouton d'or, Grenouillette.

Russian-Lutik.

Spanish-Ranunculo.

Italian-Piede di Leone, Ranuncolo, Tribulo astragalo.

Latin-Lotos corniculatus.

Danish-Ranunkel.

Swedish - Ranunkel, Smoerblomster.

Cuckoo - flower. Lucy Locket, Pinks, Spinks, Bogspinks, Mayflower, Ladysmock, Meadowcress, Cuckoopint.

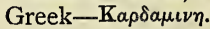

Latin-Cardamine pratensis.

French-Cresson des Prés, Cressonette, Cardamine.

Spanish-Cardamino de Prados.

Italian-Cardamina crescione.

German-Wiesenkresse, Wiesenschaumkraut.

Dutch-Koeks, Koeks bloem, Klein Waterkers.

Danish-Engekasse, Gjoge blomster.

Swedish- Ang krasse.

Polish-Rzezucha polna.

Russian-Lugo buii kres.

Cyanus. Ragged Ladies, Blue Cornflower, Blawart, Hurtsickle, Blewblaw, Bluebottle, Ragged Sailors.

Latin-Cyanus centaurea.

French - Bluet, Casselunette, Barbeau, Aubifoin.

Italian-Ciano, Battisegola.

Spanish-Ciano.

German-Kornblŭme.

Dutch-Kornbluem.

Belgian-Kornbloemen. 


\section{Flower-Names and Bird-Names}

Daffodil. Saffron Lily, Crowbell, Lent Lily, Affodyl, Glen. Latin-Pseudonarcissus.

French-Jeannette.

Italian-Asfodillo.

Spanish-Cruzcecita de oro.

German-Narcisse.

Daisy, Bairnswort, Bruisewort, because a decoction was supposed to be good for bruises. Gowan, Cockiloorie. WelshLlygady Dydd (eye of day): the Anglo-Saxon the same, daeges eage. Herb Margret (dedicated to St. Margaret of Cortona), Hen and Chicken Daisy, called Childers and Jackanapes.

Latin-Bellis perennis.

French-Paquerette, Marguerite.

German - Margarethenblume, Gänseblume, Marienblume.

Dutch - Maagdelieven, Mayzoetjes, Margarieten.

Italian-Margherita, Margheritina.

Bohemian-Sedmi Krasa, Matec njk-mensji.

Daisy Oxeye. Horsegowan, Moonwort, Midsummer Daisy, Moon Daisy.

Latin-Chrysanthemum leucanthemum.

German-Grosse Wŭcherblŭme.

French-Grande marguerite.

Norwegian-Praste.

Italian-Leucanterno, Occhio di bue.

Dandelion. Dentylion, Blowball, Priest's-crown, and others.

Latin-Leontodon Taraxacum, Dens Leonis.

French-Dent de Lion.

Italian-Dente de Leone, Macerone.

Spanish-Diente de Leon.

Portuguese-Dente de Leāo.

German - Löwenzaton, Hŭndeblŭme.

Dutch-Paarde bloem.
Dandelion_continued.

Belgic-Paarde bloem.

Danish-Löwetand.

Bohemian-Plesska.

Swedish-Lejontand.

Polish-Papawa ziele.

Russian-Molotschai trawa, and others.

Daphne. Mezereon.

Latin-Daphne Mezereum.

French-Bois Gentil, Mezereon chamelée, Laureolle femelle, Garou.

Italian - Mezereo, Laureola femina, Camelea, Biondella Mecereo.

Spanish - Mecereon, Laureola hembra, Torbisco.

Portuguese-Mezereao, Loireola femea.

German-Kellerhals, Seidelbast, Bergpfeffer.

Dutch-Peper boompje.

Danish - Kielderhels, Tisbast, Kinsbast.

Swedish - Kœllerhals, Sorbypeppar.

Polish-Wylcze lyka.

Persian-Mâdzaryoūn.

Delphinium. Larksclaws, Larkspur, Larkheel, Knightspur.

Latin-Delphinium formosum.

German-Rittersporn.

French-Pied d'Alouette, Bec d'oiseau, Eperon de chevalier.

Italian-Speronedi cevaliere,Fiorcappuccio.

Spanish-Delfinio.

Delphinium (White). Elijah's chariot, Stavesacre.

Latin-Delphinium staphisagria.

French-Staphisaigre.

Italian-Staffisagria.

Spanish-Albarraz, Yerba piojira.

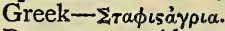

Portuguese-Alvarraz.

German-Lausenkraut, Stephans Körner. 


\section{Stray Leaves from a Border Garden}

Delphinium (White)-cont.

Dutch-Luiskruid.

Danish-Luusurt.

Swedish-Staffansfrœ, Lusoert.

Polish-Gnidosz, Ziele.

Devil's-bit. Scabious, Bluebonnets, Bluecaps.

Latin-Morsus Diaboli.

Swedish-Diefwuls bett, Baetsmans myssa (Boatman's cap or mutch).

German-Teufels abbiss.

Italian-Scabbiosa gallinella.

Dock (Water). Dock, Docken, Cushycows, Water-patience.

Latin-Rumex hydrolapathum.

French-Patience d'eau, Parelle de Marais.

Italian-Lapazio d'acqua, Idroıapazio.

Spanish-Hidrolapazo.

Portuguese-Labaca major.

German - Wasserampfer, Wassermangold.

Dutch-Water patigh.

Danish-Vandskreppe.

Swedish-Vatnsyra.

Elder. Bour-tree, Barral, Boontree, Aller, Dwarf Elder, Danewort.

Anglo-Saxon, Eller, from AngloSaxon, celd; Danish, ild; Swedish, eld, fire, probably used for firing ; " eld " fires was an old name for "bonfires."

Latin-Sambucus.

French-Sureau.

German - Hohlunder, Holder, Flieder, Zwergholunder (Dwarf Elder).

Italian-Sambuco, Sambugaro.

Spanish-Sauco.

Portuguese-Sambugeiro.

Dutch-Vlierboom.

Danish-Hyld.

Swedish-Floeder.

Bohemian-Ber.

Polish-Bzowy.

Russian-Busina.
Elder_continued.

Arabic-Ukti, Khaman.

Greek-'Aктү.

Chinese-U-chu-yu.

Elm.

Anglo-Saxon-Elm.

Latin-Ulmus.

Greek-II $\tau \in \lambda \epsilon \alpha$.

French-Orme.

Italian-Ormo.

Portuguese $\}$ Olmo.

German-Ulme.

Dutch-Olm.

Danish $\}$ Alm.

Polish-Ilm.

Russian-Ilim.

Turkish-Kasagatsch.

Forget-me-not. Mouseear, Think-me-on, Scorpiongrass.

Latin-Myosotis.

German-Vergiss mein nicht.

French-Myosotis, Nem'oubliez pas.

Swedish-Förgat mig icke.

Danish - Forglemm mig icke, Kiœrminde.

Italian-Scordio, Non ti scordar di me.

Foxglove. Witchinger, Foxfinger, Fingerwort, Thimbleflower, Bludie-bells, Dog's-lugs, Foxter-leaves, Deadmen's-bells, King's Ellwand, Bludiefingers. (Anglo-Saxon name was Foxesgliew, probably because it was shaped like an old Anglo-Saxon musical instrument which had little bells hanging from it. Our word Foxglove is probably from this.)

Norwegian-Reve bjelde (Foxbell), and Reve leika (Foxmusic), Fingerböl.

German - Waldglöckchen, Fingerkraŭt, Pŭrpŭr Fingerhŭt, Fingerhư̆tblŭme.

Swedish-Fingerborrsoert.

Danish-Rod fingerhŭt. 


\section{Flower-Names and Bird-Names}

Foxglove_continued.

Dutch-Vingerhoedkruid.

Spanish-Dedalera.

Italian-Digitale Guantelli (ditale is a thimble and a fingerstall).

Latin-Digitalis.

French-Gants de Notre Dame, Gants de Bergère, Cloche, Gueule de Loup, Digitale.

\section{Fritillary. Crown Im- perial.}

Latin-Fritillaria Imperialis.

French-Couronne Impériale.

German-Kaiser Krone.

Italian-Corona Impérial.

\section{Fritillary. Checkered Daf-} fodil, Snakeshead, Checkerlily, Ginnyflower.

Latin-Fritillaria Meleagris.

Italian-Giglio varigata.

German-Kiebitzblume.

(Curiously enough, Kiebitz is the German word for a Lapwing).

Fumitary. Waxdolls, Earthsmoke, Fumeterrie.

Spanish-Palomico.

Latin-Fumaria officinalis, Fumus terræ.

Polish-Rutha ptasza.

French-Fumeterre.

Arabic - Bucklutumeric and Scheiteregi.

Italian

Portuguese $\}$ Fumara.

Persian-Schahtra.

Japanese-Fingo sakf.

German - Erdraŭch, Taubenkropf.

Dutch-Duivekervel, Aardrvok.

Danish-Aakerssissel.

Swedish-Jordrock.

Gentian. Harvest - bells, Autumn-bells, Calathian Violet.

Latin-Gentiana.

German-Genzian.

Italian-Genziano.

French-Gentiane.

Spanish-Genciana.
Goosegrass, Robin run the Dyke, Lizzy run the HedgeGoosebill, Catch-weed, Bluidtongue, Scratchweed, Cleavers, Jack in the Way, Goosewort, Beggarman, Harriff (Hedge, robber), Loveman, Catchrogue, Gripgrass.

French-Gratéron, Philantrope.

Latin-Aparine.

Greek-'A $\pi \alpha \rho \nu \eta$.

Italian-Aparine speronella.

Spanish-Amor del' Hortelano.

Portuguese-Amor do Hortelano.

German-Klebekraŭt.

Dutch-Klatte Klauuwen.

Danish-Snerregrass.

Swedish-Snarpegrass.

Polish-Ostrzyka.

Russian-Smolnaja.

Hungarian-Ragadaly.

Grass of Parnassus.

White Buttercup, White Liverwort.

Latin-Parnassia palustris.

French-Foin de Parnasse.

Ground Ivy. Grund Davy, Catsfoot, Gill go by the ground, Alehoof (Scotch name), Tunhoof. These names came from its being used to clarify Ale in old days.

Latin-Hedera terrestris, Glechoma hederacea.

French - Lierre terrestre, Terrette.

Italian-Edera terrestre, Ellera terrestre.

Spanish-Yedra terrestre.

Portuguese-Eira terrestre.

German.-Erdephew, Gundermann.

Dutch - Hondsdraf, Aardveil, Onderhave.

Danish-Jord, Vedbende.

Swedish-Jordrefwa.

Groundse1. Grundyswallow, Simson Sention.

Anglo-Saxon - Groundswelge (Earthswallower).

Latin-Senecio. 


\section{Stray Leaves from a Border Garden}

\section{Groundsel_continued.}

German-Schwelle, Kreuzkraŭt.

French-Seneçon.

Spanish-Yerbacana.

Italian-Cardoncello spilliciosa.

Guelder-rose. Snowballtree, Marris Elder, Rose Elder, Ople, Tisty-Tosty-tree.

Latin-Viburnum opulus.

German-Wasserholunderbaŭm.

Dutch-Gheldersche Roose.

French-Boule de Neige.

Italian-Viburno.

Harebell. Haresbell, Hairbell, Witches' - thimble, Bluebells, Ladies'-thimble, Our Lady'sthimble.

Latin-Campanula rotundifolia.

Italian-Campanella giacinto.

Spanish-Campanula.

German-Englische Hyacinthe.

French-Clochette de fée, Campanule.

Hawkweed. (So called because the Hawks were said to clear their eyesight with this plant.)

Latin-Hieracium aurentiacum.

Hazel-tree. Filbyrd and its " Lambs-tails," Catkins, Hazelpalms, Aiggletts.

(The Saxon word halsian, to foretell, is probably with allusion to hazel wands being used by diviners for water and gold.) Anglo-Saxon-Hæsl.

Latin-Corylus avellana.

Italian-Nocciuolo. (Italian for Catkins is delightful Fiocchi.)

Spanish-Avellano.

French-Noisetier.

Heath. She-Heather.

Latin-Erica cinerea.

Heather, Ling, He-Heather, Griggs.

Anglo-Saxon-HæX.
Heather-continued.

Welsh-Grug cyffredin.

Irish-Fraogh.

Latin-Calluna vulgaris.

French-Bruyère.

Spanish-Brezo.

German-Heidekraŭt.

Italian-Erica.

$\left.\begin{array}{l}\text { Danish } \\ \text { Norwegian } \\ \text { Swedish }\end{array}\right\}$ Lyng.

Hellebore. Christmas-rose, Christmas-flower.

Latin-Helleborus.

French-Rose de Noel, Pied de Griffon, Rose de Serpent.

German-Christwurz, Rieswurz.

Italian-Elleboro.

Spanish-Eleboro.

Hemlock. Hemloke, Homloke.

Latin-Conium maculatum.

Greek-Kıovєเov.

French-Cigue.

Italian-Cicuta.

Spanish-Cicuta.

Portuguese-Ciguda.

German-Schierling.

Dutch-Scheerling.

Danish-Scharntyde.

Norwegian-Skarntyde. (A very local Norwegian name is Hündeslyke.)

Swedish-Sprædig odœrt.

Bohemian-Bolehlaw.

Polish-Swinia wesz.

Russian-Boligalow.

Hepatica, Poor Johnny, Trinity-flower, Liverwort.

Latin-Hepatica anemone.

French-Herbe Trinité, Hépatique.

Spanish-Hepatica.

Holly. Hollen, Holyn, He-Holly, She-Holly (prickly and nonprickly), Holy - tree, Holm, Hulver.

Latin-Ilex aquifolium. 


\section{Flower-Names and Bird-Names}

\author{
Holly-continued. \\ French-Houx. \\ Greek-'A ypıаv. \\ Italian-Agrifoglio, Alloro, Spi- \\ noso. \\ Spanish-Acebo agrifolio. \\ Portuguese-Agrifolio azevinhò. \\ Dutch-Stikpalme, Chrishom, \\ Stovtidse.
}

\section{Honesty, Pennyflower,} Moonwort, Sattin Violet, Silverplate, Lunary, Platewort, Bobbonack, Bulbonack.

Latin-Lunaris biennis, Viola lunaris.

French-Monnaie du Pape, Médaille des Indes, Herbe aux Lunettes, Lunaire.

German-Mondraŭte.

Spanish-Luna yerba.

Italian-Lunaria.

\section{Honeysuckle, Honi-} suckle. Caprifoly, Woodbind, Ladies'-fingers, Woodbine, Lily among Thorns, Eglantine.

Anglo-Saxon-Hunigsucle.

Latin-Lonicera periclimenum.

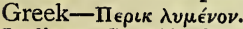

Italian-Caprifoglio, Madreselva, Vincibosco.

Spanish-Madreselva.

French-Chevrefeuille.

Portuguese-Madresylva.

German-Geissblatt, Je langer je lieber, Specklilie, Hahnen füsslein.

Dutch-Geitenblad, Mammetjeskruid, Weeuwtjes, Gewoone, Caperfoely.

Houseleek, Ayegreen, Sengreen (evergreen), Birdbread, Jupiter's - eye, Bullock's-eye, Jupiter's-beard.

Latin-Sempervivum tectorum.

French-Joubarbe des toits, Pain d'oiseau.
Houseleek-continued.

Italian-Barba de Giove, Sempreviva

Portuguese-Sempreviva.

Spanish-Sempreviva de Tejados.

German-Hauslauch (supposed to keep a house from lightning).

Transylvania-Donnerkraut.

Dutch-Huislook.

Danish-Huuslög.

Swedish-Huuslök.

Bohemian-Netresk.

(The Wall Stonecrop (Sedum acre) is known in France as Petite Joubarbe, and in Spanish as Sempreviva menor. In German it is Kleines Hauswurz. A quaint old Sussex name for the yellow variety is, "Welcome home, husband, be he never so drunk.")

Hungarian-Hazizöld.

Polish-Rozchodnik wielki.

Russian-Tschesnokdikoi.

\section{Hurtberry. Whortleberry} Huckleberry, Whurt, Bilberry, Blaeberry, Myrtleberry, Wimberry, Blackworts.

Latin-Varcinium myrtillus.

German-Preiselsbeere, Heidelsbeere.

French-Myrtille.

Spanish-Arandano.

Icelandic-Blaber.

Italian-Mora di rova, Prugnolo di rova.

Danish-Böllebar.

German-Stechpalme, Stechbaum, Waldistel, Halsendorn, Stecheiche.

Swedish-Jernek, Christorn.

Polish-Ostrokzow, Kzewina.

Russian-Waesoscheld, Ostrokrof.

Iris, Flag, Flower de Luce, Orrice, Blue Seggin (from Anglo - Saxon saeg, small sword).

Lrench $\}$ Iris.

Italian-Iride fiordaliso. 


\section{Stray Leaves from a Border Garden}

Iris, Flag-continued. Spanish-Lirio cardeno. Arabic-Asmeni juni. German-Schwertlilie. Dutch-Lisch.

Iris, Stinking. Roastbeefplant, Gladiol, Gladwin, Gladdon.

Latin-Iris foetidissima.

Italian-Iride fétida.

Iris, Water, or Yellow Flag, Water Flower-de-luce, Skegg, Saeg, Sword-lily, Seggs, Sagg.

Latin-Iris pseudacorus.

French - Glayeul des Marais, Iris des Marais.

Spanish-Acoro bastardo, Lirio espadanal.

Portuguese-Lirio amarelho dos charcos.

Italian-Iride gialla, Acoro bastardo.

German - Wasserschwŭrtel, Gelbe, Schwertlilie.

Dutch-Valsh Lis, Geel Lisch.

Danish-Swoerdlilie.

Swedish-Svardslilja.

Russian-Kasatnik.

Polish-Mieczyk z'ólty.

Hungarian-Sarga vizi Lilioin.

Ivy, Bentwood, Benwood, Bindwood.

Anglo-Saxon-Ifig.

Latin-Hedera helix.

French-Lierre.

Italian-Edera Ellera.

Spanish-Yedra.

Portuguese-Yera.

German - Eppen, Wintergrün,

Baumwinde, Eppich.

Danish-Vedbende, Vintergront.

Dutch-Klimop, Klyf, Boomveil.

Swedish-Murgrœn.

Bohemian-Brectan.

Hungarian-Fai-borostyan.

Polish-Bluszcz.

Russian-Bljustsch.

Jasmine, Naked Jasmine

Latin-Jasminoidus.

German-Jasmin.

Persian-Jâsemin.

Arabic-Ismyn.

French-Jasmin. (Mentioned as Gelsemine in old English gardening books.)

Italian-Gelsomino.

Spanish-Jazmin.

Lily, White. Mary Lilies, Madonna Lilies, Juno's Rose.

Latin-Lilium candidum.

French-Lis blanc.

Italian-Giglio bianco.

Spanish-Lirio blanco, Azucena.

Portuguese-Leirio.

German-Weisse Lilie. Yellow Lily : Goldlilie.

Dutch-Wite Lelie.

Danish-Hvid Lilie.

Swedish-Hwit Lilie.

Polish-Lilia.

Lily of the Valley, Lily Convally, Mugget, May Lily, Ladders to Heaven, Our Lady'stears, Lily Constancy, Liriconfancie, Little Dandies.

Latin-Convallaria majalis.

French-Muguet, Muguet de Mai.

German-Mai glöckchen, Mayblume.

Italian-Mughetto, Unifoglio.

Spanish-Lirio convalio, Lirio de los Valles.

Portuguese-Unifolho.

Dutch-Lelie van den Dale, Lely Convaly.

Danish-Etblad.

Polish-Konwalia.

Russian-Landisch.

Lime, Linden, Line, Tiletree, Linde.

Latin-Tilia europæa.

French-Tilleul, Tilier, Til.

Italian-Tiglio.

Portuguese-Til.

Spanish-Tilo, Tilia, Argoma.

German-Linde, Lindenbaŭm.

Dutch-Linde, Lindenboom. 


\section{Flower-Names and Bird-Names}

\section{Lime, Linden_continued.}

Danish-Lind, Lindtræe.

Swedish-Linn.

Bohemian)

Polish

Russian Lipa.

Hungarian-Harsfa.

Arabic-Ugla mur.

Japanese-Badaisin.

Anglo-Saxon-Lind.

London's Pride. None so Pretty, St. Patrick's-cabbage, Nancy Pretty, Pratling Parnell. Latin-Saxifraga umbrosa.

French-Désespoir de Peintre.

Spanish-Saxifrago.

Italian-Sassifragia.

German-Steinbrech.

Love lies bleeding. Velvetflower, Thrumwort, Florimer, Love-flower.

Latin-Amaranthus.

French-Fleur de Jalousie, Discipline des religieuses.

Spanish
Portuguese Papagayo.

German-Tausendschön.

Italian-Amarantho, Fior veluto.

Lyre-flower, Ladies' - eardrop, Clocks and Watches, Bleeding Hearts, Fumewort.

Latin-Dielytra dicentra.

Marigold, Corn. Bigolde (meaning not the true "Golde"), Goldin, Yellow-bottle, Yellow Cornflower, Yellow Oxeye, Yellow Gowlan, Yellow Daisy, Yellow Gowan; Gool, Guilde, Rudde, Boodles, Buddles, from the Dutch buidel, a purse, perhaps because the flowers were called Gools-i.e. Dutch Gulden. The word "Guilde" comes from the Danish guild, yellow.

Latin-Chrysanthemum segetum. (In old days in Scotland and, I
Marigold, Corn_continued. believe, also in Denmark, negligent farmers were fined who allowed this pretty flower to overrun the land. Hence the old saying, "The Gordon, the Guild and the Watercraw are the three worst ills the Moray ever saw.")

Marigold, Marsh. Cops, Jonettes, Kingcup, Watergolland, Yellow-gowan, Golde, Wildfire, Meadow-bootes, Goldknobs, Marybuds, Maryblobs, Mereblob, Giltcap.

Anglo-Saxon - Mersc Gealla, Marsh Golden, Craisey (said to be from Oculus Christi, but, I think, perhaps from Cruisie, a little lamp). Brave Bassinets (from the French Bassinet, the skull-cap worn inside a helmet). Buttercup, Gold-cups, Gules. The termination "cup " has been said to be a corruption of the Anglo-Saxon $c o p$, a button or rotind knob, in allusion, no doubt, to the appearance of the flower and its buds).

Latin-Caltha palustris.

German-Dotterblume.

Spanish-Mirabel.

Italian-Fioranzio paludo.

French-Bouton d'or.

Marjoram.

Greek-Opıravos.

Latin-Origanum vulgare,

French-Origan, Grand serpolet. Italian-Origano.

Spanish-Oregano.

Portuguese--Oregao.

German-Dostenkraŭt, Wohlgemŭth.

Dutch-Welde Orego, Majolein.

Danish-Tost, Vild Mairan.

Swedish-Dosta.

Polish-Lebiotka.

Russian-Duschiza.

Bohemian-Dobra mysol. 


\section{Stray Leaves from a Border Garden}

Meadowsweet, Meadwort (from Anglo-Saxon mede wyrt), Bridewort, Queen of the Meadow (American as well as Scotch). This plant was used in the drink called Mead.

Latin-Spiræa Ulmaria.

French-Reine des Prés.

Spanish - Reyna del Prado, Ulinaria.

Italian-Regina degli prati.

Portuguese-Rainha dos prados.

German-Wiesenkönigin, Geisbartwŭrzel, Mädesüiss.

Dutch-Reynette, Geitenbaard.

Danish-Miœert, Miöd ört.

Polish-Rosia brodka.

\section{Milfoil. Milfoil, Wild Pepper,} Hundred-leaved Grass, Thousand-leaved Clover, Comnion Yarrow, Nosebleed, Carpenters'herb.

Latin-Achillea millefolium.

French-Herbe aux Charpentiers, Millefeuille.

Italian-Millefoglie.

Portuguese-Milfolha.

Spanish-Milenrama.

German-Schaf garbe.

Dutch - Duizenblad,

Haaze gerwe.

Danish-Jordhumble, Roe Uike.

Swedish-Roel lika.

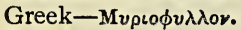

Polish-Tysiacznil ziele.

Milkwort. Crosseflowre,Gangflower, Rogation-flower, Procession-flower.

(This pretty little flower was so called because it was worn in wreaths by the maidens who walked in procession in Gang week, three days before the Ascension. The object of these processions was to mark parish boundaries, and Litanies were sung and the blessing of God asked upon the crops.)

Latin-Polygala vulgaris.

French-Laitier, Polygala.

Italian-Poligala.

Spanish-Lechera, Poligala.

\section{Milkwort_continued.}

Portuguese-Leitera, Poligala.

German-Milchblüme, Kreuz-

blŭme.

Dutch-Kruisbloem.

Danish-Kaarsblomster.

Swedish-Jungfru mariælin.

Polish-Wyczka Konicza.

Russian-Iztod.

Japanese-Fima fagi.

Mullein. Kingkerz, Fairies'blanket-flower,Adam's Blanket, Moleyne, Jupiter's-staff, Hightaper, Candlewick-flower, Higtaper, Hag (Hedge) taper, Hare's-beard, Cow's-lungwort. Ladies' - foxglove, Shepherds' clubs.

Latin-Verbascum thapsus.

French-Bouillon blanc, Bonhomme, Moltène, Herbe de St. Fiacre (patron of cabdrivers).

Italian-Tasso barbasso, Verbasco.

Spanish-Verbasco, Gordolobo.

Portuguese-Verbasco bianco.

German - Königskergenkraŭt, Himmelbrand, Wollkraŭt.

Dutch-Wollekruid, Koningskaarsen.

Danish-Kongelys.

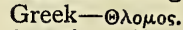

Swedish-Kungsljis.

Polish-Dzlewanna ziele.

Russian-Zaarskii skipetr.

(The old name of Hig-taper seems to have come from a custom of dipping the stalks in tallow and using them as torches or tapers at funerals.)

Narcissus. Poetica, Poets' Narcissus, Sweet Nancie, Pheasant's-eye.

Latin-Narcissus.

$\left.\begin{array}{l}\text { Spanish } \\ \text { Italian }\end{array}\right\}$ Narciso.

French - Narcisse, Jeannette blanche

German-Narcisse.

Greek-Napкıбoos. 


\section{Flower-Names and Bird-Names}

Orchis. Male - foolstones, Aaron's-beard, Cockskames, Goose and Goslings, Deadman's-thumb.

Latin-Orchis mascula.

Greek-0 oxıs.

French - Orchis, Testicule de Prêtre, Sabot de Vénus.

Italian-Orchide, Satirione.

Spanish-Orchis, Satyrionmacho.

German-Mannliches Knabenkraŭt.

Dutch-Kulletjes kruid, Mannetjes harlekyn.

Arabic-Sahleb.

\section{Orchis latifolia. Cocks-} kames, Deil's-foot, Deadmen'sfingers, Cain and Abel, Adam and Eve, Foolstones.

German-Knabenkraŭt.

French-Orchis.

\section{Orchis maculata. Fool-} stones, Hand Orchis, Addergrass, Henskames, Deadman's. hand.

Pansy, Three Faces under a Hood, Herb Constancy, Banwort, Pawnce, Pink of my John, Flamy, Jump up and Kiss me, Herb Trinity, Heartsease, Birdseye, Kiss me behind the Garden-gate, Love in Idleness.

Latin-Viola tricolor.

American - Ladies' Delight, Johnny jump ups, Johnnie Jumpers, Kit run about.

Dutch-Viool.

German-Stiefmütterchen, Veilchen.

Spanish-Trinitaria, Violetta.

French-Pensée.

Italian-Viola del Pensiero, Pensieri Menuti.

Peony. Pione, Pianet, Chesses. Latin-Pœonia.

Spanish-Peonia, Rosa del Monte, Rosa alberdera.

Portuguese-Peonia, Rosa albardeira.
Peony-continued.

German-Konigsblŭme, Pfingstrose, Gichtrose, Konigsrose.

Dutch-Peonie.

Danish-Peon, Gigtrose.

Swedish-Pion.

Polish-Piwonia.

Russian-Pionnaja rosa.

Greek-IIaıovı.

Periwinkle. Clematis, Pervincle, Pervinkle, Sorcerer's Violets, Ivy of the Ground.

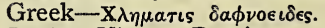

Latin-Vinca, Pervinca minor, Clematis Daphnoides minor.

French-Pervenche, Violette des Sorciers.

Italian-Pervinca centocchio.

Spanish-Vinca pervinca, Yerba Doncella.

Portuguese--Pervinca.

Germany - Kleines Sinngrün, Wintergrün, Jungferskrone, Ungrün.

Dutch - Vinkoorde, Maagden palm.

Danish-Singroen.

Polish-Barwinck.

(Pervinca comes from Pervincere, to conquer.)

\section{Petunia.}

Latin-Petunia.

French-Pétunia.

Brazilian-Petun(means Tobacco).

Phlox. Farewell Summer, Good-bye Summer.

Latin-Phlox paniculata, Phlox Drummondi, \&c.

Pink. Gillyflower, July-flower, Incarnation, Sops in Wine, Whitsuntide Gillyflower, Carnation, Gilivors, Piggesnie (from Pingsten eye).

Latin-Dianthus, Caryophyllus (Clovepink).

French-Gillet, Giroflée musquée (Clovepink).

German-Pfingsten (Whitsun), 


\section{Stray Leaves from a Border Garden}

\section{Pink-continued.}

Nelke, Levkoje, Incarnat, Gartennelke.

Italian - Garofano, Leucoio, Viola garofanata.

Dutch - Angelier geplümele anjelier, Pingster.

Spanish - Clovellina, Clavel, Encarnacion, Clavelon.

Danish-Fieruellike.

Russian-Gwosdika.

Maiden Pink, (called in German Wiesennelke).

Planten, Plantain, Waybred, Wabret, Wayborn, Kemps, Waytread.

Latin-Plantago major.

Swedish-Wagbredblad, Grodblad.

German-Wegetritt, Wegerich.

French-Plantain, Grand Plantain.

Italian-Piantaggine inaggiore.

Spanish-Llanten mayor.

Portuguese-Tanchagem major.

Dutch-Grosse Weggbree.

Danish-Vejbred.

Polish-Labka.

Russian-Popuschnik.

Persian-Kanasch.

(Translation of Red Indian name, Whiteman's-foot.)

Poppy. Cornrose, Cockeno, Cockscombs, Redweed, Thunder-flower, Cheesebowls, Headache, Coprose, Jone Silverpin, Papig.

(Joan's Silverpin is a synonym in East Anglia for a bit of finery on a slut.)

Latin
German Papaver.

French-Ponceau, Coquelicot, Pavot.

Spanish-Ababot.

Italian-Papavero.

Primrose, Primerolle, Primerose, Mayspink, Plumrock.

Latin-Primula vulgaris.

French-Primevère.
Primrose_continued.

Italian-Primavera.

Spanish-Bellorita.

German-Primel.

Quaking-grass. Trembling Jockey, Sillertassels, Silvery Cowquakes, Ladie's-hair, Trembling-grass, Dothering Docks, Siller-shakle, Fairy-grass, Hairgrass, Wagwants, Pearl-grass, Quakers and Shakers, Doddergrass.

Latin-Briza media.

French-Briseau, Brise, Amourettes tremblantes.

Spanish-Brize.

Italian-Loglio inebbriante.

Rest Harrow, Stinking Tam, Ground Furze, Cammock, Petty Whin, Stay plough.

Latin-Ononis Arvensis.

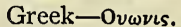

French-Arrêtebœuf, Bugrane.

Spanish-Detienebuey, Remora de arado.

Portuguese-Restaboy.

Italian-Arresta bué

German - Stallkraut, Ochsenbrech, Hauhechel.

Dutch-Ossenbrecke, Stalkruid, Prangwortel.

Rocket. DamesViolet, Rogue's Violet, Winter Violet, Queen's Violet, Close Sciences (corruption from Damascena). It was, I believe, originally brought from Damascus, and was first called a Damask Violet.

Latin-Hesperis.

French - Giroflée, Violette de Damas.

German-Nacht viole.

Italian-Ruchetto.

Rose. Dog-rose, Canker-rose, Dog-hep.

Latin-Rosa canina.

French-Rosier des Chiens,Eglantier, Rosier des Haies. 


\section{Flower-Names and Bird-Names}

Rose_continued.

Italian-Rosa canina, Rosa salvatica.

Spanish - Escaramujo, Rosal canina, Rosa silvestre.

Portuguese-Rosa brava.

German-Hundsrose, Wilde Rose, Hagebutten.

Dutch-Hondsroos, Wilde Roozeborm.

Danish-Hybentorn.

Swedish-Niupon.

Polish-Rosa pulna.

Greek-Kvvoposov.

(Thename Dog-rose is said to have been given in allusion to the value of the root as a remedy against hydrophobia. Rose is from the Celtic rhos, red.)

Rosemary (Herb of the Sea). Seaden.

Latin-Rosmarinus, Herba coronaria.

French-Romarin.

Spanish-Romero.

Italian-Rosmarino, Romerino.

Portuguese-Rosmarinho.

German-Rosmarin.

Dutch-Rosmaryn.

Arabic-Klil, Hasalaban achsir.

Chinese-Yong tsao.

Scurvy-grass. Spoonwort.

Latin-Cochlearia.

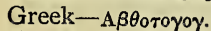

French-Herbe aux Cueillers.

Italian

$\left.\begin{array}{l}\text { Spanish } \\ \text { Portuguese }\end{array}\right\}$ Coclearia.

German - Löffelkraŭt, Löffelkresse, Scharböckskraŭt.

Dutch-Lepelkruid, Lepelsblad.

Danish-Skeeurt.

Swedish-Skedoert.

Polish-Warzech wa.

Shepherd's-pouch. (The old name of "Clappe de pouch" arose from its resemblance to the wallets of the wayside begging lepers, who carried small clappers to attract notice,
Shepherd's-pouch_cont.

and were nicknamed "Clappe de pouches.") Shepherd'spurse, Ladies'-purses, Toywort, Pickpurse, Poor Man's Parmacetty.

Latin-Thlaspi, Bursa pastoris.

French - Bourse à pasteur, Cabaret des oiseaux, Bourse de Capucin.

German-Täschelkraŭt.

Spanish-Azara bacara.

Silverweed. Dog's Tansy, Prince's Feather, Trailing Tansy, Fairdays, Goosegrass.

Latin-Potentilla anserina.

French-Argentine, Quintefeuille, Potentille.

Italian-Argentina.

Spanish-Argento.

Sloe. Slae, Blackthorn, Scroggs, Skegg, Snag, Slaigh.

Latin-Prunus spinosa.

French-Prunier épineux, Prunellier, Prunier sauvage.

Italian-Prugnolo.

Spanish-Endrino, Ciruelo sil vestre.

German-Schlehdorn, Schlehendorn, Schwartzdorn.

Dutch-Sleedoorn, Sleepruim.

Danish-Slaetorn, Kreygeboertorn.

Swedish-Sloan, Starkbar.

Anglo-Saxon-Rla, Slah.

Snowdrop. Bulbous Violet, Fair Maid of Feb. Purificationflower.

Latin-Galanthus.

German - Schneeglöckchen, Schneetropfen.

Swiss-Amselblŭme.

French-Perce neige.

Spanish-Campanilla blanca,

Italian-Galanto foraneve.

\section{Southernwood. Old Man,} Lad's Love, Boy's Love, Averogne.

Latin-Artenisia Abrotanum. 


\section{Stray Leaves from a Border Garden}

\section{Southernwood-continued.}

French-Garderobe, Citronelle, Aurone des Jardins.

Italian

$\left.\begin{array}{l}\text { Spanish } \\ \text { Portuguese }\end{array}\right\}$ Abrotano.

Dutch-Averoon.

German - Aberraŭte, Stabwurz, Gartwurz.

Danish-Abrodd.

Swedish-\#brodd.

Bohemian-Brotan.

Speedwell. Fluelling, Germander, Milkmaid's-eye, Cats'eyes, Angels'-eyes, Eyebright, Paul's Betony.

Latin-Veronica Chamædrys.

French - Véronique, Thé des Jardins.

Italian-Veronica, Vaniglia selvatica, Camedrio.

$\left.\begin{array}{l}\text { Spanish } \\ \text { Portuguese }\end{array}\right\}$ Veronica.

German - Ehrenpreis, Mannertreue, Studentenliebe.

Dutch-Gemeene, Eerenprys.

Danish-Aarenpriis.

Swedish-Erenpreis, Jord Krypa.

Polish-Przetacznik.

$\left.\begin{array}{l}\text { Russian } \\ \text { Bohemian }\end{array}\right\}$ Weronyka.

Spindle-tree. Wayfaringtree, Prickwood, Skewerwood, Gatter, Gaitre (Chaucer), from the Anglo-Saxon gad, a goad, and Hris, a rod.

Latin-Euonymus.

French-Fusin, Bonnet de prêtre. Italian-Fusaggine.

German-Spindelbaŭm, Pfaffenhütchen.

Portuguese-Birete de cerigo.

Spanish-Bonete.

St, John's-wort. Rose of Sharon.

Latin-Hypericum.

French-Herbe St. Jean, Millepertuis.

Italian-Iperico.

Spanish-Hiperico, Yerbe de San Juan.
St. John's-wort-cont.

Portuguese-Milfurada.

German-Johanniskraut.

Dutch-St. Jan's Kruid, Mansbloed.

Danish-St. Hans urt Jordhumle, Perikum.

Swedish-Johannisoert.

Russian-Sweroboi.

Bohemian-St. Jana bylina.

Polish-Dziura wiec.

\section{Strawberry.}

Anglo-Saxon-Streow burie.

Latin-Fragaria vesca.

French-Fraise.

German-Erdbeere.

Spanish-Fresa.

Italian-Fragola.

Portuguese-Fragaria.

Dutch-Aardbezien.

Danish-Jordbær.

Swedish-Jordgubbar, Smultron.

Polish-Poziemka jagodi.

Sweetbriar. Hepthorne, Eglantine, Pimpernel Rose.

Latin-Rosa rubiginosa.

German-Hägrose.

Spanish-Gavauco.

French-Aiglentier.

Sweet William. London Tufts, Sweet Johns, Painted Ladies, Tolmeiner.

Latin-Dianthus barbatus.

Italian-Garofanetto salvatico.

German-Bartnelke.

Toadstools, Pixystools, Fuzzball. (Pixy was, I believe, the feminine of Puck.) Frogstools. Latin-Fungus.

French-Oeufs du Diable.

Italian-Fungo.

German-Erdschwamm, Giftpilz.

Tulip, Tulipase, Turk's-cap, Satyrion, Dalmatian.

Latin-Tulipa.

French $\}$ Tulipe. 


\section{Flower-Names and Bird-Names}

Tulip_continued.

Dutch-Tulp.

Italian-Tulipano.

Spanish-Tulipan.

Persian-Dulbend.

Turkish-Thoulyban.

\section{Violet.}

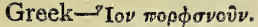

Latin-Viola odorata.

Italian-Viola, Violetta, Viola marzia.

Portuguese-Violetta.

Spanish-Violeta olorosa.

German-März veilchen.

Dutch-Tamme Viool.

Danish-Martsfioler.

Wallflower. Cherisaunce, Wall Stock-gillofer, Bloody Warrior, Bleeding Heart, Heartsease.

French-Giroflée.

Latin-Cheiranthus cheiri.

Moorish-Keiri.

Wolfsbane. Aconite.

Latin-Aconiturn.

Spanish-Aconito.

Italian-Aconito.

French-Aconit.

Swedish-Aetka fioler.

Polish-Fiolki.

Russian-Pachutschaja fialko.

Armenian-Manischar.

Chinese-Kiet tuong hoa.
Woodruff. Woodsweet, Sweetgrass, Woodsorrel. Woodderowffe.

Anglo-Saxon-Woderofe.

Latin-Asperula.

French - Asperule, Hépatiqueétoilee, Petit muguet.

Italian-Asperula odorata.

Spanish-Asperula olorosa.

Portuguese-Asperula odorosa.

German-Waldmeister, Sternleberkraut, Lebenkraunt.

Dutch-Weiriekend, Rawkruid.

Woodsorrel. Hearts, Alleluia, Stubwort, Woodsour, Cuckow's-meate. Sour Trefoil, Gowks'-clover, Gowks'-meate, French Sorrel.

Latin-Oxalis acetosella.

French-Oxalide, Pain de coucou, Surelle, Alleluia, Oseille de Bucheron.

Italian-Acetosa salvatica, Alleluja.

Swedish-Giokmat, Harsyra.

Portuguese-Azedinha, 'Trevo azedo.

German-Sauerklee, Buchampfer, Kuck kucks lee.

Dutch-Zuurklaver, Koeks koeks brood.

Danish--Skovsyrer, Suur klover, Giogeurt.

Polish-Szezowik.

Russian-Saits chait, Schawel.

Bird-names do not seem to be so often synonymous, but I will put my Bird-notes here, as it may be interesting to compare the Bird-and Flower-names. No one can be more sensible than I am of the imperfection of these notes both as regards the Bird-and Flower-names, and $I$ feel that the Indian proverb describing a person who has embarked on an enterprise insufficiently prepared may be applied to me: "He took a plough of grass and grasshoppers for oxen." My excuse must be Linnæus' motto, "Tantus amor florum,' so deep is my love of Flowers, and, I may add, Birds. 


\section{Stray Leaves from a Border Garden}

Blackbird. Ouzel, Merle.

Latin-Merula merula.

French-Merle.

Itaiian-Merlo.

Spanish-Mierlo.

German-Amsel.

\section{Bullfinch. Chickadee, Alp,} Nope, Pope, Monk, Coallyhood.

Latin-Pyrrhula europæa.

German - Dompfaff, Gimpel Rothfink.

Italian-Fringuello marino.

Spanish-Fringelago.

French-Bouvreuil.

(The word "finch" is from the Anglo-Saxon Finc, a small bird.)

Chaffinch, Scobby, Skelly, Shel-apple, Shilfa, Beechfinch, Hoosefinch, Pink, Appershealer, or Apple - shealer, Spink, Chink.

Latin-Fringilla Cœlebs.

German-Buchfinke.

French-Pinson.

Spanish-Pinzon.

Italian-Pincione.

Cuckoo. Gouckoo, Gowk. Celtic Cuach, British Cog.

Latin-Cuculus, Canorus.

French-Coucou.

Spanish-Cuco.

Italian-Cuculo.

Dutch-Kuck-kuck.

Icelandic-Goukr.

Danish-Gjoge.

Goldfinch. Goldie, Goldspink, Thistlefinch.

Latin-Carduelis carduelis.

Italian-Cardellino or Cardeletto (meaning Thistlebird). Cardeto

is a waste covered with thistles.

German-Stieglitz.

French-Chardonneret.

Spanish-Pintacilgo Paxarel.
Greenfinch, Green Lintie,

Green Grosbeak.

Latin-Ligurinus chloris.

Italian-Verdone.

Spanish-Verdecillo.

German-Grünfink, Hirsenvogel.

French-Verdier.

Hedge-sparrow, Hempie.

Latin-Accentor modularis.

French-Fauvette d'hiver.

German-Weidensperling, Grasmücke.

Italian-Forasiepe (which also means a "poor little man." This word is sometimes applied to the Wren).

Heron. Herne, Hegrie, Heronshaw.

Latin-Ardea cinerea.

German-Reiher, Fischreiher.

Italian-Airone.

Spanish-Garza.

Danish-Heyre.

Norwegian-Hegre.

Kingfisher. King's fisher.

Latin-Alcedo ispida.

French-Alcyon, Martin pêcheur.

Italian-Alcione.

Spanish - Alcion, Martin pescador.

German-Eisvogel.

Lapwing. Peewit, Tewit, Whaup, Teuchit, Peeseweep.

Latin-Vanellas, Vanellus.

French-Vanneau.

Italian-Pavoncella.

German-Kiebitz.

Linnet. Lintie, Lyntquhit.

Latin-Cannabina.

Spanish-Pintaroxo.

German-Hänfling.

Italian-Fanello. 


\section{Flower-Names and Bird-Names}

Nightjar. Churr, Dorhawk. (Dor is an old word for Beetle), Fernowl, Goatsucker, Puckeridge.

French-L'Engoulivent.

Latin-Caprimulgus.

Owl. Howlet, Hoolet, Ivy-owl, Tawny-owl.

Latin-Syrnium, Aluco.

French-Hibou, Chathuant.

Gernian-Eulo.

Spanish-Buho.

Italian - Civetta, (also means coquette).

\section{Robin Redbreast.} wink, Woop, Ruddock.

Latin-Erithacus rubecula.

German-Rothkehlchen, Thomas Gierdet.

French-Rougegorge.

Italian-Pettirosso.

Spanish-Pettirojo.

(In Norway it is called Peter Ronsmad, and in Finland Thomas, and about Bornholm Tomi Liden.)

Sand-martin. Called also Bitterbank and Crane, was called in Spain Papillon de Montagna; in Arabia, EI Hadji the Pilgrim.

Starling, Stare, Stirlin, Steerling.

Latin-Sturmes vulgaris.

Italian-Stornello.

French-Etourneau.

German-Staar.

Swallow. Arrondell, Swift Deviling, Screamer.

Latin-Hirundine.

Italian-Rondino.

French-H irondelle.

German-Schwalbe.

Swedish-Swala.

Spanish-Golondrina. (This word also means a Deserter.)
Thrush. Throstle, Stormcock, Mavis, Greybird.

French-Grive.

German-Drossel.

Latin-Turdus musicus.

Titmouse. Blue Tom Tit, Huckmuck, Muskin, Bluecap, Oxeye, Nun, Billybiter, Tittereen.

Latin-Panis cæruleus.

Anglo-Saxon-Mase.

Spanish-Alionin.

Swedish-Mes.

French-Mésange bleue.

Dutch-Mees.

German $\}$ Meise.

Italian-Cinci allegra.

Titmouse, Coal.

French-La petite Charbonnière.

Wagtail. Peggy Washdish, Dishwasher, Seedbird, Willie Waterwagtail.

Latin-Motacilla lugubris.

German-Bachstelze.

Italian-Cutrettola.

Spanish-Motacila, Motolita.

French-Motacille, Bergeronette, Lavandière.

Woodpecker. Witwall, Woodsprite, Rainbird, Woodwall, Hewhole, Poppinjay, English Parrot, Pick-a-tree, Rainfowl.

Latin-Picus.

Italian-Picchio.

Spanish-Picoverde.

French-Pivert, Pic vert (old Roman name, Pluvius aves).

German-Baumhecker.

\section{Woodpecker, Brown.}

Tree-creeper.

Latin-Certhia familiaris.

German-Kriecher.

French-Grimpereau. 


\section{Stray Leaves from a Border Garden}

Woodpigeon. Ringdove, Cushat, Cushiedoo, Culver, Quest, Queest, Kowsehot, (Wild-pigeons were called in Spain Palomas Ladrones, or Robber-pigeons).

Anglo-Saxon-Culfre.

Latin-Columba palumbus.

German - Ringelstaŭbe, Holztaŭbe.

Italian-Colombo salvatico.

Spanish - Paloma zurrana, or Torcaz.

French-Pigeon Ramier.

Wren. Goldcrest, Kinglet, Marigold-finch, Wearie Miller'sthumb.

Latin-Regulus.

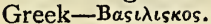

Wren-continued.

German - Zaunkonig (Hedgeking).

Spanish-Reyezuelo.

French-Roitelet.

Italian-Réatino, and Fiorranz io, which means "little Marigold." Swedish-Ellekongi.

Dutch-Kungsvogel.

Russian-Winter Koninkje.

Yellow-hammer. Yorlin, Yeldrock, Yowley, Yite, Gladdy, Yellow-bunting," Little bread and no cheese."

Latin-Emberiza, Citrinella.

German - Goldammer (ammer meaning Bunting).

Italian-Rigogolo.

French-Le Bruant.

The Wryneck is among the Border birds, but he is rare, and I have never had the luck to see one. 


\section{CHAPTER XIII}

\section{VERNACULAR OF THE BORDER}

IN the course of my investigations about Flowers and their names I have been much struck with the manner in which the Border vernacular has preserved, sometimes unchanged, the terms given by the people of different nationality who have lived in the country. The hind of the Merse, without being aware of it, talks a mixture apparently of AngloSaxon and of the language which still survives in Iceland, the tongue of the old-time Vikings, Danes, Swedes and Norsemen, all of whom in their day lived on the Border. The very word "hyne" or "hind," which has been applied to farm-servants since time immemorial, is from the AngloSaxon hine, or hineman. "Ye'll gang by the Dene to the haugh to see till the yowes," he says. Here "gang" is "to go," from Anglo-Saxon gangan, to go; Icelandic, gang-a. "Dene," a wooded hollow, from Anglo-Saxon Den. "Haugh," a riverside flat or pasture, from Icelandic hagi. "Till, til," Anglo-Saxon, til; Icelandic, til, to. "Yowes," ewes; Anglo-Saxon, eowe; while the old Pictish or Belgic words was oye and ouwe. The Picts and Belgæ seem to have been akin to the Saxons.

Nowadays the farm-servants have taken exception to the time-honoured term of " hind," and declare it is demeaning to their dignity to be so called. The word, therefore, is now less used. They prefer being called "agricultural labourers." I have heard that the country folk in Sweden and Norway apparently care little for gardening, and do not cultivate 289 


\section{Stray Leaves from a Border Garden}

gardens round their cottages with common fruit and vegetables and borders of flowers, such as scarcely any Border cottage is ever without. Such cottages with attendant kailyaird were probably the earliest form of garden. Indeed, the word "yard," pronounced yaird, comes from the AngloSaxon geard, meaning an enclosure, and has been used for a garden since time immemorial. Chaucer talks of "yerde" for garden ; indeed, I feel much more able to understand Chaucer since I live in Scotland. After work-a-day hours the Borderer may frequently be seen delving in his bit patch among the berry-bushes or the flowers; and though, perhaps, the result may not always be as effective to the eye as in more southern sunkissed parts of Britain, yet it is not for lack of gentle care and tending. The following are a number of Scottish words showing kindred words in Danish, Swedish, Anglo-Saxon and Icelandic. The abbreviation Su.-G. means Sueo-Gothic, or ancient language of Sweden.

The pronunciation of these words is, I believe, generally the same as the Danish.

\begin{tabular}{|c|c|c|}
\hline $\mathrm{SCOTCH}$ & ENGLISH & FOREIGN EQUIVALENTS \\
\hline Allars & Alders & $\begin{array}{l}\text { Elletraer (Danish); Alr (Anglo- } \\
\text { Saxon). }\end{array}$ \\
\hline Airt & Quarter of the heavens & Vart (Icelandic). \\
\hline Aik & & Eik (Icelandic); Ac (Anglo-Saxon). \\
\hline Aron & m or Cuckoopint & Aronsœrt (Swedish). \\
\hline To ax & & Axian (Anglo-Saxon). \\
\hline kbword & ngboard & Backbword (Danish). \\
\hline Bairn & $\mathrm{Ch}$ & Barn (Danish). \\
\hline Bide & To & Bie (Danish). \\
\hline Bid & fite & Byde (Danish). \\
\hline & uild & Bigge (Danish); Byggie (Icelandic). \\
\hline Biggin & ding & $\begin{array}{l}\text { Bygning (Danish); Byegan (Anglo- } \\
\text { Saxon); Bigging (Icelandic). }\end{array}$ \\
\hline Byke & Hive of bees & $\begin{array}{l}\text { Biikar (Icelandic); Biebuyck (Teu- } \\
\text { tonic). }\end{array}$ \\
\hline Byre & ov & Byr (Danish). \\
\hline Birk & D & $\begin{array}{l}\text { Biorki (Icelandic) Birc (Anglo- } \\
\text { Saxon). }\end{array}$ \\
\hline Bittie & bit & Bitte (Danish). \\
\hline Blaeb & $\begin{array}{l}\text { Bilberry } \\
\text { (Vaccinium Myrtillus) }\end{array}$ & Blaber(Icelandic);Blabaer(Swec \\
\hline Braw & Finely dressed & Braer(Icelandic);Braf(Sueo-Gothic). \\
\hline Brig & Bric & $\begin{array}{l}\text { Brygge(Sueo-Gothic); Bricg (Anglo- } \\
\text { Saxon). }\end{array}$ \\
\hline Blackadder & Name of a river & $\begin{array}{l}\text { From Awweddur, running water in } \\
\text { Celtic-Gothic dialect. }\end{array}$ \\
\hline
\end{tabular}




\section{Vernacular of the Border}

\begin{tabular}{|c|c|c|}
\hline SCOTCH & ENGLISH & FOREIGN EQUIVALENTS \\
\hline $\begin{array}{l}\text { Brose } \\
\text { Kailbroo }\end{array}$ & Broth & Ceales briu (Anglo-Saxon), \\
\hline Burn & Brook & $\begin{array}{l}\text { Brunnr (Icelandic); Byrna (Anglo- } \\
\text { Saxon). }\end{array}$ \\
\hline Cauld & Cold & $\begin{array}{l}\text { Kalt (Icelandic); Ceald (Anglo- } \\
\text { Saxon). }\end{array}$ \\
\hline Cheipers & Cricket insect & $\begin{array}{l}\text { From the Icelandic Keipar, to make } \\
\text { a slight noise. (This expression } \\
\text { is also used in America.) }\end{array}$ \\
\hline Carline & Old woman & Karlinna (Icelandic). \\
\hline $\begin{array}{l}\text { Cooslip } \\
\text { Crowstairs }\end{array}$ & Cowslip & Cuslyppe (Anglo-Saxon). \\
\hline Cushat & Dove & Cusceote (Anglo-Saxon). \\
\hline Curlykale. & Curled colewort & $\begin{array}{l}\text { Krullkrael (Icelandic); Kruskael } \\
\text { (Danish). }\end{array}$ \\
\hline Daft & Silly & Dauf(Icelandic);Doef(Sueo-Gothic). \\
\hline Docken & Dock a plant & Docken (Anglo-Saxon). \\
\hline Drift & Flying snow & $\begin{array}{l}\text { Drifa (Ícelandic); Drifan (Anglo- } \\
\text { Saxon). }\end{array}$ \\
\hline Dyke & Drystone wall & $\begin{array}{l}\text { Dige (Danish); Dic (Anglo-Saxon); } \\
\text { Dike (Sueo-Gothic). } \\
\text { Drifwa (Sueo-Gothic). }\end{array}$ \\
\hline Drucken & Drunken & Drukken (Danish). \\
\hline & To change houses & Flitte (Danish). \\
\hline Ferritickled & $\begin{array}{l}\text { Freckled } \\
\text { Possession }\end{array}$ & Fregne (Danish). \\
\hline & $\begin{array}{l}\text { Possession held on pay- } \\
\text { ment of rent }\end{array}$ & Feo (Anglo-Saxon). \\
\hline Fog, fug & Moss & Fug (Danish). \\
\hline Fogie & $\begin{array}{l}\text { Old person or invalid } \\
\text { soldier }\end{array}$ & Fogde (Sueo-Gothic). \\
\hline Fremfolk & Strangers & $\begin{array}{l}\text { Fremmede folke (Danish); Fremd } \\
\text { (Anglo-Saxon). }\end{array}$ \\
\hline Graip & $\begin{array}{l}\text { Three-pronged garden- } \\
\text { fork }\end{array}$ & Grepe (Sueo-Gothic). \\
\hline $\begin{array}{l}\text { Muckfork } \\
\text { Gait }\end{array}$ & & Möggreve (Danish). \\
\hline $\begin{array}{l}\text { Gait } \\
\text { Gang yer ain } \\
\text { gait }\end{array}$ & $\begin{array}{l}\text { Way } \\
\text { Go your own way. }\end{array}$ & Gata (Icelandic). \\
\hline Haud & To hold & Hald (Danish). \\
\hline To hap & To cover & Hiupr (Icelandic). \\
\hline Hansel & An earnest & Hansel (Danish). \\
\hline $\begin{array}{l}\text { Hollen } \\
\text { Ingaan (to a }\end{array}$ & Holly & Holen (Anglo-Saxon). \\
\hline Kirk) & in going & \\
\hline $\begin{array}{l}\text { Hasp } \\
\text { Hoos }\end{array}$ & Latch & Haspe (Danish). \\
\hline Hawthorn & May & $\begin{array}{l}\text { Huus (Danish); Hus (Anglo-Saxon). } \\
\text { Hagadorn (Anglo-Saxon); Hage- } \\
\text { dorn (Modern German). }\end{array}$ \\
\hline Hindberry & Raspberry & $\begin{array}{l}\text { Hindbaer (Danish); Hindberrie } \\
\text { (Anglo-Saxon). }\end{array}$ \\
\hline $\begin{array}{l}\text { Kailstock } \\
\text { Kail }\end{array}$ & Cabbagestock & Kaalstok (Swedish). \\
\hline Kailyaird & Cabbage-garden & Kaalgaard (Danish). \\
\hline Kailwc & Caterpillar & Kaalorm (Danish). \\
\hline \multicolumn{3}{|c|}{$29 I$} \\
\hline
\end{tabular}




\title{
Stray Leaves from a Border Garden
}

\author{
SCOTCH \\ ENGLISH \\ FOREIGN EQUIVALENTS \\ Kemps \\ Ribgrass (Plantago lan- Kampar (Swedish). \\ ceolata)
}

(This plant is also called "Soldiers" and "Fightee-cocks" here, and in old Scotch ballads the word Kemps is used for a warrior.)
Kersses
Watercress
Kilt
Scotch dress
Caerses (Anglo-Saxon).
Kitling
Kitten
Kiolt(Icelandic); Kilt (Sueo-Gothic).
Kitling (Danish); Kittsla (Sueo- Gothic).

- (This word Kitling is used by Herrick.

\begin{tabular}{|c|c|}
\hline $\begin{array}{l}\text { Knowe } \\
\text { Kirkyard } \\
\text { Ling }\end{array}$ & $\begin{array}{l}\text { Hillock } \\
\text { Churchyard } \\
\text { Heather }\end{array}$ \\
\hline Law & Hill \\
\hline Larick & Lark \\
\hline $\begin{array}{l}\text { Laverock } \\
\text { Loft }\end{array}$ & Upper room \\
\hline Lowe & Flame \\
\hline Laird & Landowner \\
\hline
\end{tabular}

Knolle (Danish).

Lammie sou- Sorrel (a herb) rocks

\begin{tabular}{|c|c|}
\hline $\begin{array}{l}\text { Little ane } \\
\text { Lucken } \\
\text { Luckengowan } \\
\text { Midden }\end{array}$ & $\begin{array}{l}\text { Child } \\
\text { To lock } \\
\text { Globeflower } \\
\text { Dunghill }\end{array}$ \\
\hline Mickle & Much \\
\hline $\begin{array}{l}\text { Mire } \\
\text { Mirk }\end{array}$ & $\begin{array}{l}\text { Bog } \\
\text { Dark }\end{array}$ \\
\hline $\begin{array}{l}\text { Moudiewart } \\
\text { Moldwarp } \\
\text { Moudie hoop }\end{array}$ & $\begin{array}{l}\text { Mole } \\
\text { Molehill }\end{array}$ \\
\hline $\mathrm{Neb}$ & Beak, nose \\
\hline $\begin{array}{l}\text { Neep } \\
\text { Ousel, Ouzel } \\
\text { Onsted } \\
\text { Paddockhair } \\
\text { Pade } \\
\text { Paddockstool } \\
\text { Padder } \\
\text { Paddock } \\
\text { Pictarnie } \\
\text { Quern } \\
\text { Reek }\end{array}$ & $\begin{array}{l}\text { Turnips } \\
\text { Blackbird } \\
\text { Farm building } \\
\text { Down } \\
\text { A toad } \\
\text { Fungus } \\
\text { To tread over } \\
\text { Frog } \\
\text { Tern } \\
\text { Handmill } \\
\text { Smoke }\end{array}$ \\
\hline
\end{tabular}

\section{$\left.\begin{array}{l}\text { Rauntree } \\ \text { Rowan }\end{array}\right\} \quad$ Mountain ash}

Kirkgarth (Danish)

Ling (Danish, Swedish, and Norwegian).

Hlaewe (Anglo-Saxon).

Lawerc (Anglo-Saxon).

Loft (Danish).

Lue (Danish).

Laward (Sueo-Gothic); Lavardur (Icelandic); Hlaford (AngloSaxon).

Lamba surd (Icelandic).

Lytling (Anglo-Saxon).

Lucan (Anglo-Saxon).

Which is tightly closed.

Mödding (Danish); Midding (Anglo-Saxon).

Mikil (Icelandic); Micel (AngloSaxon).

Myrr (Icelandic).

Myrkur (Icelandic) ; Myrce (AngloSaxon).

Moldwrat (Anglo-Saxon).

Moudie hoop; Knoop (AngloSaxon).

Naeb (Danish); Nebbe (AngloSaxon).

Naep (Anglo-Saxon).

Osle (Anglo-Saxon).

Onsted (Anglo-Saxon).

Paddenhayr (Teutonic).

Pade (Anglo-Saxon).

Paddenstoel (Teutonic).

Pad (Teutonic).

Podda (Icelandic).

Iderne (Danish); Tarna (Swedish).

Qvœrn (Danish).

Rög (Danish); Reikr (Icelandic); Recan (Anglo-Saxon and SueoGothic).

Ronnetraer (Danish); Ronn runn (Sueo-Gothic). 


\section{Vernacular of the Border}

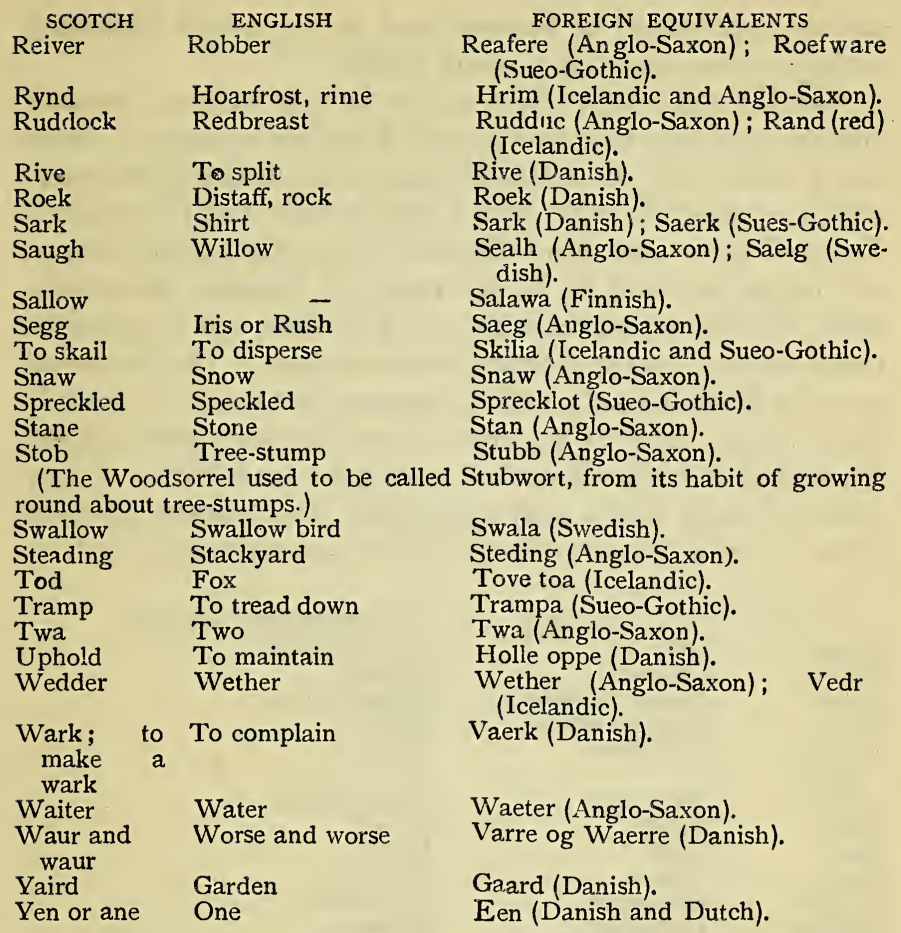

Imperfect and slight as are the above notes, they yet show how deeply the old lingual tracks remain, stamped into the ground. To any one who is desirous of further investigation, I recommend the reading of Prof. Veitch's charming "History and Poetry of the Scottish Border" where the subject is dwelt on at length. In Jamieson's Dictionary there is also a most interesting introduction, showing how the language talked in olden days by the Vikings of Scandinavia had survived in Iceland, and how Jamieson was led to collect the local expressions around him, first in a small way in an old copy-book, by meeting with Thorbrelin, a Danish Professor of Antiquities, who said he had been much struck by recognising in Scotch local talk 


\section{Stray Leaves from a Border Garden}

sundry expressions he remembered in his native Icelandic, perhaps more correctly termed Gothic.

The French words which are to be met with in common talk are probably due to the early friendship between Scots and French, and the many French and Scottish royal intermarriages which brought over French who settled inScotland. The well-known names of Sinclair, Fraser, Campbell, Betoun and others are said to be of French or Norman extraction, while Thorburns, Andersons, and Johnsons, not to mention many similar, betray a Scandinavian origin. The following are a few French words, which, however, are not so commonly used as they used to be, since Board Schools have helped the spread of " high English" amongst the children. Thus some of these words only survive in Law papers and old ballads and in Plant-names, more or less transmogrified.

\begin{tabular}{|c|c|c|}
\hline SCOTCH & ENGLISH & FOREIGN EQUIVALENTS \\
\hline Aschet & Dish & Assiette, plate. \\
\hline Awmrie & Cupboard & Aumrie. \\
\hline Backet & Trough for ashes & Baquet, a tub. \\
\hline Bailie & Borough official & Baillie. \\
\hline $\begin{array}{c}\text { Braverie, } \\
\text { braws }\end{array}$ & Fine attire & Braverie. \\
\hline Caddie & Messenger & Cadet, junior. \\
\hline Douce & Gentle & Douce. \\
\hline Dule & Grief. & Deuil. \\
\hline Dules & Weeds. & Deuil. \\
\hline Gardrop & Cupboard & Garderobe. \\
\hline Herison & Hedgehog & Hérisson: \\
\hline Houris & Matins, singing of birds & Heures, livre d'heures. \\
\hline Gigot & Leg of mutton & Gigot. \\
\hline Merle & Blackbird & Merle. \\
\hline Mutton & Sheep & Mouton. \\
\hline Nourice & Nurse & Nourrice, or Anglo-Saxon Norice. \\
\hline Obeyssance & $\begin{array}{l}\text { Subjection (old forensic } \\
\text { tern) }\end{array}$ & Obéissance. \\
\hline Persil & Parsley & Persil, \\
\hline Pernicketty & Particular & Parniquet. \\
\hline Perrakit & Chattering child & Perroquet, parrot. \\
\hline Policy. & Grounds & Policé. \\
\hline Recepissy & Recipe & Recipissé. \\
\hline Rosignell & Nightingale & Rossignol. \\
\hline Roseir & Rosebush, arbour & Rosier. \\
\hline Servite & Napkin & Serviette. \\
\hline Soc & Ploughshare & Soc. \\
\hline Summer & Summary & Sommaire. \\
\hline
\end{tabular}




\section{PART II}

\section{MY FRIENDS IN THEIR \\ GARDENS}




\section{MRS. MOSS}

THERE are scarcely any of us who are utterly without friends in this world, but who among us can say we know our friends thoroughly? We may know our friends more or less well, but there are generally sides to all of us which remain; like the farther side of the moon, undiscovered and unknown to the other. But there are certain tastes which would seem to be more or less magnetic, and the possessors of these likings generally become aware of others having the same tastes. Such is the love of gardening, and there is a sort of freemasonry among flower-lovers which often bridges speedily the first slow steps of acquaintanceship. A garden is so reflective, to my mind; it takes on the character of the possessor, at least of the possessor who delves in it as some do, with a single mind, and careful attention born of the affection he or she bears to every inch of ground. This may be the old gardener who has bent his back since the days of his prime in taking care of the Castle gardens, scarcely known to their nominal possessor, the county magnate's wife, who spends the best season of the year in Vanity Fair, where she is only reminded of Spring by the varied and beauteous flower-beds in the Park. The squire's heart may be in his acres, and often is, but little he cares for the prim alleys and fancy beds his mother instituted, and the lad who had his early training under her strict eye takes a pride in keeping up as old missus directed. Not of such gardens would I speak, but rather of the haunts wherein the love of quiet souls bears fruit. In the neighbourhood of country towns 


\section{Stray Leaves from a Border Garden}

there are often to be found these gardens, havens of rest, where one feels, as one enters the old mossy avenue, that the tumult of the outer world will scarcely penetrate beyond the moss-grown walls and yew hedges. There are no children here to pull about the beds and pluck the flowers, the young birds have all flown and the old pair are alone in their old ivied house. Mr. Moss is away, in the Knights Acre, or the Little Croft, or some such quaintly-called portion of his surrounding domain, wandering very probably along the banks of his favourite brown trout stream. Mrs. Moss comes to meet us, her skirts daintily pinned up, and laden with flower-scissors, basket, and trowel. "Doing a little gardening, my dear!" she says. She proposes adjourning to the upstair drawing-room, where the striped blinds are down to protect the old carpet from the Spring sun, but her eyes sparkle when the sincere request is made to stay out and see the garden. The Myrtle has almost overgrown the porch, and she says with a smile, Mr. Moss's mother planted it. By Mr. Moss she always means her husband; this type of old lady would think shame (as the graphic old Scottish idiom hath it) to speak of her husband as Tom, Dick, or Harry. But new years new customs; perhaps the wives of Tom, Dick, and Harry, for all their rough speech, may not be less true-hearted. In front of the door, and so placed that the little drive winds round them, is an old-fashioned round plot subdivided by tiny paths into six V-shaped beds, like slices of cake, bordered by box. Here there are a few cherished Standard Rosetrees, of which Mrs. Moss knows every name, and dwells fondly on their glories in the seasons that have been, and prophesies what will be in the days to come. But the present beauty of these beds is Spring loveliness-wellfed clumps of golden Oxslips and velvety Polyanthus, scarlet Tulips, and intermixed masses of blue Forget-menots. The latter has overrun the little paths, and Mrs. Moss uproots sundry intruding plants and says they must be thrown away, it is too luxuriant. And thrown aside they will be, on a heap of refuse by a hedge, and will take 


\section{My Friends in their Gardens}

root and wander thence into the neighbouring field, for sticks, if planted, would, I think, grow and flourish in the rich soil of red Devon. Then Mrs. Moss smiles on her Hyacinths, which in handsome upstanding pride fill one of the beds all to themselves, blue, cream-coloured and rose-pink ; there are no jarring tints here. "I do not like violent colours," she says ; and adds, "They came direct from Holland all these ; are they not beautiful ?" with an innocent pride in them which one feels deserves absolution if ever that so condemned sin does. She has Pansies, too, prune-coloured and black and golden and steel-blue, and talks, as she picks us a specially large flower, of Heartsease and quotes Shakespeare: "There's Pansies, there's for thoughts!" Wood-anemones with their delicately tinted petals are there also, and the richer, deeper red and purple hues of the Globe Anemone from the far-off Riviera, whence, too, has come to this warm corner of Devon the little dark blue Grape or Starch Hyacinth. " Do you not think they smell of French Plums?" she says, and one knows that, if one should chance to dine some evening in the old house, French Plums will come up at dessert in their fancy box, as of old in our grandmother's time. "See my speckled Fritillaries, my Checker Lilies," and she points where, amid a forest of green leaves, rise the grey-green swordlike spears and brown shaded bells, with speckled throats, of the graceful and bewitching Quakers of the flower-garden. Close by are the Crown Imperials, splendid in red and gold. "I love these," says Mrs. Moss simply. "My Annie was always so fond of them." There is no sadness in her tempered voice, although to us there seems there might have been, for it is long since Annie has gone to the land where fairer flowers are said to blow, "another land than ours, even the land that is very far off." But when one feels that every day brings one nearer to reunion, and that the time cannot be very long, I suppose that the keen edge of parting is worn blunt and the wild and wearing sorrow of youth does not invade the soul of the elder.

"Oh! the beautiful yellow Tulips," we cry, and go down 


\section{Stray Leaves from a Border Garden}

on our knees to admire the beautiful oval blooms, one or two of which are over-blown and look like golden stars. Mrs. Moss smiles, and gives the Latin name, Sylvestris, with delicate careful pronunciation, adding: "I am glad you like my Goosebills; I got them first from an old woman in the village, but I believe they are really the only wild Tulips of England. She told me her mother called them Goosebills, because in their arching stems they resembled the geese curving their necks on the village-green. Now they grow like weeds, and I can scarcely keep them down at all. I cannot give them all the garden." She looks round as she speaks; all the garden is comprised in these few beds, a small green lawn where, beneath the Beech-tree in Summer, she asks her friends to partake of Strawberries and Devonshire cream, and a tiny walled garden where grow espaliered fruit-trees and vegetables intermingled in old-fashioned friendliness with budding Lilies of the Valley, Forget-menot, Auriculas, Bearsfoot, as Mrs. Moss calls it, and pinkpurple Primroses. Later on here will be wealth of oldtime Roses, Cabbage and Moss, and Golden Iris, and bluepurple Iris, Pinks and Carnations ; but in the meantime it is Spring, and the fruit-trees are only showing leaves and a few stray early bunches of flower. Under the trees on the lawn there is a perfect carpet of wild Celandines-Swallowswort somebody delightfully calls it -and somewhat apart, under a Pine-tree, a colony of wild Cyclamen have spread themselves, much to Mrs. Moss' delight. She knows every inch of ground in her domain and rejoices in it as a mother in her child. Who has not some friend or friends like dear old Mrs. Moss ? Thank God, there are many such still left in this nineteenth-century utilitarian age who still make Potpourri to fill old China bowls and ungrudgingly fill your hands with their choicest flowers, as we reluctantly take leave and go forth from that calm oasis out into the world's bustle again. But, reader, if you will come with me, there are pleasant gardens in other walks of life which we may visit together, and, as some old writer hath it, "perchance to the refreshing of our soules." 


\section{JOHN BURNET}

THE little house stood close to the imposing gateway of the Laird's wide domain. The stone Bears which surmounted it seemed to be showing their tusky teeth in contempt of the poor little grey stone cottage. There was lichen on its roof which, however, boasted lovely gold-coloured blossom ; I always fancied it grew brighter there than anywhere else. Burnet was the "factor's man "; in other words, gardener and groom, and odd man to the Laird's land agent, who lived a little bit down the road round the corner. But, somehow or other, he always found time to work in his own little garden, either early morning or late evening, and it was always the picture of neatness. A pocket-handkerchief might have covered the whole, and one of the patchwork quilts I sometimes saw hanging out to dry at the back-the Berry-garden as he called the little slip where he grew his potatoes and greens, and watched anxiously the budding of his half-a-dozen Currant and Gooseberry bushes. But he always had beautiful Gooseberries; "Grosarts" he called them. Certainly he would never pick them before they grew to a good size; he maintained they were poison when small. I think nowhere do Gooseberries attain a finer size than in Scotland. The cottage was at the junction of two roads, the highroad to the county town and the road to the village or "oor toun," as the people about called it, a collection of straggling, whitewashed, dreary-looking houses, of which it might have been said very truthfully,

Melancholy had marked them for her own. 


\section{Stray Leaves from a Border Garden}

Their only redeeming point was a slip of garden attached to each tenement, invariably supplied by the Laird. I think Burnet's abode had been built as a model cottage in the halcyon days when farmers paid their rents and lairds had money; at any rate it had a neat little iron gate and railings covered with Virginia Creeper, and did not look out of repair. The three or four white flagstones laid down between the gate and the door were always scrupulously white and clean, as white as the mass of Snowdrops which, earlier than anywhere else, used to fill the one little round flower-bed. The Laird's wife used to look enviously upon Burnet's ewe-lamb, and declare that her grand gardener did not keep her flower-beds like Burnet did his. But Burnet loved his garden. Never was a weed suffered to live; the place was smooth and clean as John's chair on Sundays, when, as elder in the village kirk, he handed round the old wooden ladle for the pence. He had a few Double Snowdrops he had begged, borrowed, or-I was going to have said stolen; I mean- "lifted " somewhere, and they were the pride of his heart. In one corner under the parlour window he had an old earthenware pot, a sort of imitation Etruscan vase, and in this he cherished Crocuses, purple and yellow, and afterwards a red Geranium when the weather allowed. But the said Geranium spent most of its time in the "room," the somewhat close atmosphere thereof being considered more conducive to its well-being. He had Polyanthus too, and a wonderful red Turncap Lily, which was a gorgeous bit of colour later on in the season. He was trying to coax a yellow Jasmine to climb up the wall of the house, but whether it was that it objected to the cold wind off the distant North Sea, or what, I do not know, but grow it would not, in spite of all his attentions. He had a clump of Daffodils too, but not the common ones which grew within the Laird's garden-gates, in the woods, but one he had paid money for, a large size with a deep bright calyx. Of this he was very proud.

Mrs. Burnet did not seem to take much interest in John's doings so long as he attended to the "Berry-garden." That 


\section{My Friends in their Gardens}

was all she wanted, and she was wont to be wroth when, in the excitement of gardening in the summer, John delayed to come and eat his supper. But the little grandchild took an interest in the flower-bed, and would willingly have pursued amateur culinary researches with the bulbs; she was about five or six, and used to sit on the doorstep, nursing a black doll the "Leddy up at the hoose" had given her, a curious contrast to Bella's golden hair and apple-blossom face. I don't think Burnet liked big flowers, I never saw any Hollyhocks in his little place, though they flourished in some of the neighbours' gardens well. He had Violets and a few Pinks and Hyacinths, and an old bush of Wallflower, that never seemed to mind being knee-deep under the snow every winter, put on as early as might be its brown velvet suit and scented the air around it. Once Bella was told to hand me three Snowdrops through the railings, and I think that was the only time I ever saw Burnet pick any of his flowers; he used to say he could not bear to condemn "thae bonnie things to deeth." And it was quite by chance I discovered he used to take a bunch of his best blooms every Sabbath afternoon to a poor bedridden boy down the road who could not get out to see them for himself. I met Burnet once at Lame Gibbie's, and so found it out. And never was any one more shamefaced than John when I laughed and said: "So that's where your flowers go, John!" as we left the cottage together.

There are no flowers there now, the broad lands of the Laird have fallen into the dirty hands of the "deil's spawn," as his mail-clad ancestors used to term a lawyer. An Edinburgh writer reigns up at the "Hoose," and Burnet's little bark, like others, went under when that gallant ship, The Laird, foundered on the Sea of Life. 


\section{THE MAJOR}

I NEVER see a glorious show of Tulips or Hyacinths without being reminded of my old friend Major Tiffin. How fond he was of the gorgeous blooms, and how successful his gardening operations always seemed to be! Flowers are said only to grow well in the gardens of those who love them. He was a retired Indian officer, who, after a long life spent in heated struggles with Punjaubees and Sikhs (he had begun life in the days when lads started in life at sixteen or earlier, and had probably seen many a battle before they were twenty), had subsided to daily struggles with Green-fly and Slug, Caterpillar and Wireworm, and all the host of minor woes which beset the true gardener. He had only a tiny garden, but admirably adapted for beautifying. Up the cliffs of an old quarry he had trained Roses in what novels call "wild profusion," and well did the lovely Eglantines and their fellows repay his clever care.

On the inclined banks in the lush grass, grew pink and cream-coloured Peonies, tall White Lilies, Red Lilies, Columbines of all colours, Auriculas, and a thousand pretty things, each of which he knew by name. But I think the old garden to me looked its prettiest in Tulip and Narcissus time, when, in the grass on the sloping banks, I saw the many different Narcissus and red and yellow Tulips peering at their sweet will, unchecked above the grass blades, when the Bluebells, white and blue, were to be seen in thick clumps under the Lilac-bushes, and when in the first warm evening of May I accompanied the Major on deliberate visits of inquiry to each beloved clump. I remember the sunny 304 


\section{My Friends in their Gardens}

mornings when his sister, the bright, sunny old Irishwoman, who kept house for "Brother," as she always called him, would sally out with her scissors and basket and cull, with tender care, not to leave unsightly gaps, some flowers for decorating the parlour, or to send to some less happy soul who was without a garden. Or that the precept, "Let nothing be wasted," be obeyed, just before leaving the house on any journey she would carefully pick over the flowers in the sitting-room vases, and pack them up, to be sent elsewhere to rejoice some one else, rather than they should wilt unappreciated after she was gone. Dear old people, they could not bear to hear of any one wanting flowers! To give and receive cuttings was their delight, and many were the plants which recalled to them some pleasant hour in some one else's garden. They liked to feel they were linked to other people, perhaps far away, thus. And yet, small as was the circle of their interest, their ideas were not narrow. They had travelled so far and wide, they could scarcely look at plant or shrub without being reminded of either its original habitat or of something resembling it. The stunted Rhododendrons by the gate recalled to the Major old haunts in the hills of India, where their splendid beauty was a thing to dream of. The Alpine-garden, as he proudly termed his corner full of stones and Alpine plants tenderly tucked in among the crevices, reminded him of Swiss cliffs and glaciers! Each flower was to brother and sister a friend, whom they greeted joyfully with each recurring season, and made preparations to welcome suitably. Non-flower lovers felt themselves in a strange land, with strangers who talked a strange jargon, when wandering in that garden with its owners. But such true flower-lovers as were privileged to be introduced to his pets by the old Major never forgot the pleasant hour. And when, as will be, brother or sister is called away to a fairer land thar ours, the one who is left will turn for consolation to the sweet children of Earth they planted together, and over which they used to join in rejoicing. 


\section{MADAME KRACH}

BuILT of creamy-white Arles-stone, it was the model of a classic villa on a hillside by the blue Mediterranean. It belonged to a French railway king, who suddenly appeared in a certain quiet little town of Provence, and bought a tract of land in the neighbourhood. According to the traditional custom of these parts, he began by clearing away nearly all the Aleppo pines, the Myrtle, and Rosemary brushwood that clothed the hillside; then, to replace these and hide the unsightly scars, he planted Oranges and Lemons, Palms and Yuccas, with spires of white Bellflowers (better known, perhaps, as "Spanish Bayonets"), Roses, Geraniums, and endless blue Aloe, feathery Peppertrees, yellow-flowering Mimosa, Eucalyptus or "Gum-trees." Of all the old vegetation-rank Lentiscus, giant Ling, white almond-scented Heather, creeping Smilax, Butcher's-broom -nothing escaped, except here and there a few Arbutus, or "Strawberry-trees," whose shrublike appearance saved them. In the midst, slowly and at much expense, up rose his white palace, with a broad terrace whence he could see over the shining sea and the dark pine-clad hills surrounding the neighbouring old seaport. To watch the progress he took up his abode in the block of stabling already built, and almost a villa in itself, full of beautiful white-and-gold furniture, waiting to be transported to the as yet roofless suites of pillared apartments in the slowly rising villa. $\mathrm{He}$ was accompanied by a pale dark-eyed woman, said to be his wife. Always alone, she seemed to spend her time driving about the country in a fine carriage, drawn by four 306 


\section{My Friends in their Gardens}

grey percherons, with postillions clad in blue-and-silver jackets, yellow breeches tucked into high boots, and blue caps with great silver tassels. I met her once, wandering in a vineyard. She said she was in search of Roman coins (the district had formerly been a favourite watering-place of the Romans, and below the tranquil waters of the landlocked bay could be traced ruins of their houses). I remember how strange she looked in her gay Paris hat with feathers, trailing her velvet gown over the hard red clods of earth among the vines, followed by a little frisking white Maltese dog. Another time I trespassed involuntarily in the gardens of the rising palace.

Having wandered along the beach, I suddenly found myself, on turning the corner of a low wall, within the precincts of the garden, if you can so term a rather overgrown slope where the native wild shrubs contended for the mastery with newly-planted Orange-trees. I followed a little path upward, and came to an old grotto, one grown with Maidenhair Fern, which I afterwards heard was said to be an ancient Roman fountain, in the midst of arches that were all that remained of baths built by the Romans. The lonely lady was there, sitting among the Geraniums and Aloes, with a book in her hand, but her eyes fixed on the far-off sea. She greeted me, and I apologised for my unpremeditated intrusion. We got into conversation, and somehow or other I learnt that she liked sitting there because it reminded her of her old home-a prim little house in the suburbs of Paris, where her father had loved Geraniums and treasured a fancy Rockery, and she had helped him to garden and collect coins. Now he was dead and the house was sold. She had been poor then; now her husband was said to be fabulously rich. She asked me to come and see her again. "Do come, madame," she said, "I . . . I am very lonely." But I was obliged to leave the neighbourhood very shortly, and when the next year I came back the villa had passed into other hands. There had been a smash, and one day the millionaire disappeared as suddenly as he had come, leaving a load of debt in the confiding little 


\section{Stray Leaves from a Border Garden}

town hard by for the many luxuries that had been in perpetual request-baskets of Alpine Strawberries in the early days before they ripen sufficiently to claim an entire train to take them to Paris ; Mandarin Oranges when scarcely to be had ; and early vegetables or "Primeurs" when they were almost worth their weight in gold. And then the villa remained deserted, a lovely classic ruin in appearance, with green Acanthus-leaves creeping up and covering the scattered blocks of white stone and the prostrate columns of the unfinished colonnade. The shrubs and Palm-trees grew with the wild luxuriant energy of the South, and San Salvador became a favourite resort with strangers wintering in the neighbourhood, who were wont to picnic on the beach, by the side of the poor departed lady's bathing-box, which no longer ran smoothly down its tiny railroad from the shelving bank to the purple blue water. She was gone, and I often wondered what had become of her, as I marked the bushy blazing Geraniums and thought of her pale pathetic face-such a contrast to the noisy buxom English who at intervals wake the deserted solitudes with their laughter and wondering speculations. There was a report in the little town once that $\mathrm{M}$. Krach had been seen very poor in Barcelona or Madrid. I wondered whether the poor lady were not perhaps, after all, happier than in the days when I saw her. 


\section{THE RECTOR}

$\mathrm{He}$ was one of the old school-a scion of an old county family, highbred and handsome in appearance, always dignified, well-brushed, and courteous alike to prince and peasant. It was a rare pleasure to hear him read, whether it were the beautiful prayers of the old English liturgy, rolling forth his petitions as if he hoped to take far Heaven by storm, or by his own fireside, when, having carefully adjusted his gold spectacles, he took his beloved Herrick or Milton, and opened at some favourite passage. The fresh morning sweetness of Wordsworth and Cowper were his delight. But once the weather admitted of his working among his flowers, much to the disgust of Mrs. Bread, his old housekeeper, he was, as she put it, "allays a-grubbin' in that garden!" He was sufficiently well-to-do to keep a curate, who worked energetically in the small and quiet parish. Mr. Howard confined himself to going occasional rounds of visits and preaching a taking sermon once a week. But there was always plenty of broth and port-wine to be had at the Rectory, and Mrs. Bread declared she might as well keep house for a man with ten children at once as for the solitary Rector.

The Rectory was a square, solid-looking house, with baywindows. There were Red Roses climbing up the walls, but Mr. Howard did not allow the Roses' wild spreading branches full scope; he trimmed them sufficiently to allow the windows to open. "I love fresh air," he said; "neither man nor beast can live without air." There was a Fig-tree, too, on one more sheltered wall of the house. It was 


\section{Stray Leaves from a Border Garden}

always thick with leaves, but the fruit was small and seldom came to perfection. There were five or six tall Lime-trees on one side of the lawn, beneath which the Rector was wont to stroll with his cigar in the summer evenings, with his crutch-handled stick, contemplating his Beehives against the wall and listening with placid smile to the soothing hum of the Bees, the "musical hounds of the fairy ring, who hunt for the golden dew . . . in the green coverts of spring." He was very fond, too, of Hyacinths and Tulips-he used to say he was quite a Dutchman in his love for the latter. But perhaps his favourite flowers were Lilies. There were great clumps of these heavy-scented tall lovelinesses in his garden-beds along the margin of the lawn, and under the red garden-wall were tall blue Monkshood and a border of pretty grey and golden Primroses. In the hot summer afternoons, how often have I found him sitting in his little greenhouse smoking. "I smoke here for the benefit of the Green-fly," he used to say, looking round upon his Begonias and Geraniums. There was something very restful about the old man among his flowers. Even his dogs partook of the character of the man; they never routed in the flowerbeds or scratched the lawns, and allowed the dingily-clad petitioners for help to come unmolested to the back door, and like a Scotch shepherd's collie, the Rector's rough grey terrier, Bounce, would escort his master to the church-door and wait by the entry into the vestry. Indeed there was a tradition that once upon a time, the door having been carelessly shut, there was an irruption of Tyke and his companion Bounce into the very church to lie with eager topaz eyes at the foot of the pulpit. But although the garden was quiet, and seemed a very Eden of rest, it was not empty. During all the summer months it was the unselfish old man's custom to invite a succession of visitors to enjoy the country sweetness. From dingy suburbs, from stuffy London backstreets they came-pale young clerks, who gained strength in country walks, or sometimes a husband and wife, reft with difficulty from their grinding household cares, to taste unruffled peace and plenty of good food. 


\section{My Friends in their Gardens}

Indeed, once I remember the dear old bachelor carried his loving kindness so far, he actually bespoke the visit of a pale-faced, poverty-stricken couple and their puling babe, who awoke the heretofore tranquil echoes by persistent wailing. I remarked upon these unwonted and discordant sounds. He smiled his sweet benevolent smile: "Yes, it does cry a good deal, but, poor little soul, I hope the country air will do it good, and," with a twinkle in his eye, "I think it must be getting stronger; its cries are louder!" He was very liberal-minded, and though very loyal to his own Church, deemed it but right to be careful to "live in peace with all men," and in consequence was known to respond civilly to overtures on the part of the Wesleyan minister, and was more than suspected of having given somewhat to the building of a Bethel in the far end of the parish the while he contributed largely to the handsome restoration of the parish church. He was known to have lent his field for a Wesleyan school-feast, and he was beloved alike by Churchmen and Dissenters. His was the home of peace, and its beams radiated afar. 


\section{LOTOSLAND}

That was what we called it to ourselves, Annie and I, thè lovely sunny land whither we had painfully travelled to try and conquer health for Annie, grown thin and white and weak. Our finances were low; we could only afford, after paying the long weary journey to the South of France, to instal ourselves in a small back room in a dingy faded hotel in a side street of the old town.

And how pleasant to our eyes, as they grew weary of the dusty white boulevards, was the garden of Mon Repos, where, under a Rose-covered loggia, we could sit and rest, and feast our eyes on the grey-blue Aloes and bright Geranium in gorgeous mass below the red beetling cliff whereon the gleaming pigeons settled, clinging with their tiny crimson feet. But it was Roses to me, that garden-great pink masses of sweetness, golden and crimson delights, with quaint French names, such as La France, Souvenir d' un Ami, Reine Marie Henriette, Ma Frisêe, Paul Néron, Souvenir de Malmaison; we would carry away bouquets cut with no stingy hand by the sweet mistress of that garden. We would find her weeding some precious corner, kneeling on a grass mat, her dark blue linen skirt daintily tucked up, her small brown hands waging war with weed or snail; or, in the cool of the evening, after our hot dusty walk up the long hill, how pleasant to find her watering the flowers, faint with the heat of the day! When was it prettiest, that garden ? When the old Fig-trees were beginning to bud and the pale blue Iris Stylosa just opening its delicate flowers; when the giant Violets, "nothing behinde the best," as old Lawson 


\section{My Friends in their Gardeñs}

saith, "for smelling sweetly;" literally scented the garden; and could not be picked fast enough, and the Cherry-trees were all white with delicate snow, like a dream of Japan, and the Oranges were giant bridal bouquets? Or when the May sun was hot, and the garden was very still, no breeze stirring the leaves, the Roses all a-bloom, when even the burnished pigeons seemed to feel the heat, and sat very still in crevices of the red rock till the sun went down and the old white Owl came from his eyrie on the cliff-top among the Evergreen Oak scrub, where he sat hidden all day, and flew noiselessly to and fro? In the evening, when the waterpipes were opened, and the welcome sound of the running water was to be heard down amongst the Orangetrees, where, among the parched hot scarlet Geraniums of the Geranium-hedge, trickled swift rivulets, the evening breeze stirred faintly in the quivering Bamboos and ever ragged Bananas, and shook the grey Olive-leaves; the Bats began to fly - the "birds of darkness," - then the sweet mis. tress of the garden came and walked about in it, listening to the shrill sweet piping of the Nightingales and the responsive croak of the young ones. I do not know when was the most pleasant time. Oh! indeed,

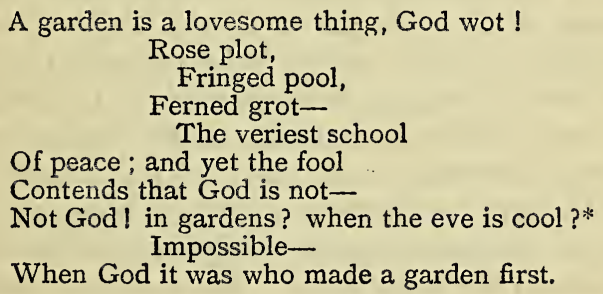

Ah ! when Annie lay weary on her sofa, the sight of the flowers from Mon Repos reminded her that there is, thank Heaven, other things in this world beside pain, and there are yet folk who try to brighten the dusty wayworn lot in life that falls to some.

* By Rev. T. E. Brown. Published by Macmillan. 


\section{Stray Leaves from a Border Garden}

How lovely was the grey Olive-yard, with the gnarled crooked old trees with the brown sheep eating the weedy grass that grew in patches anong the outstanding roots, watched by their shepherd, a picturesque figure in his long brown sheepskin cloak, who, when the time for departure came, would call his sheep to follow him away down the dusty road. But the Violets in that garden, what masses of loveliness !-dark "Czars" and that Choice Flower of Delight, sweetest "Marie Louise," whom I always wished had a more suitable name. The Violet was Napoleon's flower, and at one time after his fall no one dared wear the sweet compromiser. Bunches of Violets used to be drawn, in which, after careful search, the Bonapartist sympathiser might find in one flower the profile of the well-beloved Petit Caporal. There were palest Parma Violets, some of which always found their way to the bedside-tables of people who could not get out to gather flowers for themselves. Then there were red-brick tanks full of Goldfish, where the tall Reeds and Water-lilies hid cheerful Frogs, blue and green, and a sleepy Tortoise, and in the sunshine Dragon-flies flitted to and fro. There was a small carved stone shrine up against the rock in a corner half hidden by a wild Cherrytree, with a curious old-fashioned Virgin and Child in it, the antiquity of the style shown by the Virgin being represented holding the Babe on her hand instead of in her arms. There was also a Dripping Well half-hidden by Bamboos and Bananas, and Beehives in an old quarry shaded by Pomegranate-trees, but these were, alas! no joy to their owner, as they had become demoralised by flowers being always to be had, and did not make honey properly in stores, but lived from hand to mouth like vagabonds. No one ever came within those iron gates who did not want to come again; there was a welcome for all, for orphan children from the convent school in the dull back street, who came to spend a happy day under charge of blue-robed sisters; or languid invalids muffled up in furs, longing with sick hearts for their far-off English homes, and deeming the Oleander-hedges and Pomegranate-trees of the South a poor exchange for the 


\section{My Friends in their Gardens}

green hedgerows and wide Turnip-fields of their native shores.

There were some who would be constant visitors to that garden, creeping thither with daily slower steps, to depart thence with hands filled with flowers, and hearts cheered by cheerful words, till at last they came no more, and the flowers went to them instead, and finally, laid to rest in the hillside God's-acre, the flowers marked their resting-place. Anne used to talk of our home in England in the grey cathedral town, in the shady close where the earliest Snowdrops grew under our window, and then she would say : "But I think we shall never forget Mon Repos, shall we, Pleasance?" And though I am now far away across the sea, and it is long since Anne has been called away to the land where "the gardens never wither, and the meadows green and dewy shine with Lilies wondrous fair," the remembrance of Lotosland is still fresh to me, and my beloved Lady, in her Garden of Rest, is very near my heart. 


\section{$\mathrm{JACOB}$}

He was old and withered and black-black as ebony or as a well-polished boot. He never seemed to do anything in his garden, as, pass when I would at the end of the rutty lane, I was sure to see him crouching on his doorstep in the shadow of his Banana with its great wind-torn emerald leaves. There were always some of his apparently multitudinous descendants busy in the tiny compound, and somehow or other enough Yams and other roots were gathered together to feed the tribe, probably with a good deal of unrecognised help from the neighbouring fields of master's Bananas and Cocoa. The hut was low and tumble-topieces in appearance, but beautified by the gorgeous red and yellow plumes of the "Pride of Barbados," which grew tall and luxuriant by the door. There were tangled Yam-vines and Aralias, many-coloured Cannas, a Nutmegtree with its quaint pear-shaped fruit and sweetest of flowers, and a perfect little thicket of "Coffee-rose" bushes, their white Gardenia-like flowers perfuming the air heavily. I stopped to admire a bronze-hued baby one day playing under the Orange-trees, wholly naked save for a string of blue beads encircling its rounded neck. My admiration of his grandchild pleased old Jacob, and he vouchsafed a few civil words, rather to the doubting satisfaction of my escort, a stalwart but very superstitious negro, who feared " overlooking" by one reputed an Obi man, and feared and respected as much as a "wise woman" used to be in an English village, or a "spae wife" in a Scotch one, not so very long ago. The wonderful knowledge of the good and 


\section{My Friends in their Gardens}

bad properties of herbs often possessed by reputed Obi men and women will account in the minds of unbiased folk for the ascendency they obtained over the minds of the vulgar. And we can scarcely blame the West Indian peasant for superstition when we recollect how in these our own days even, an old woman was actually accused of witchcraft in Galloway, and the crime believed in by most of the Christian folk round about. The next time passing I admired the wild Balsams springing at their own sweet will in the little garden, and Jacob gave me a beautiful posy of then, though apparently he was rather surprised at my taste. After a while we became friendly enough for me to dismount and study slowly the different bushes in the little corral. I learnt to know the different Yams apart and tried to identify the shrubs under the queer and often uncommon names given to them by the negro, who, though fond of flowers in a way, never seems to give any one an individual name. "Missis like a Rose ?" would be the usual remark and preface to a bunch of any flower available. When it dawned on Jacob Missis loved birds and flowers, he one day stopped me as I was riding by and said, "Missis cae to see a Collobree's nest ?" Wondering what I should see, I dismounted and followed Jacob to the back of his hut, where there was a big Breadfruit-tree. Among the branches of some shrubs near it he showed me a tiny little nest made of brown sheep's wool, partially covered with white lichen, such as was on the tree. A sweet little green Humming-bird flew off as we approached, and Jacob was amply rewarded by my delight.

I need scarcely say it was not the only visit I paid Mahme Collobree, and she grew to be wonderfully tame, and would continue sitting even while I looked at her. When at last the tiny eggs gave place to little imps looking somewhat like Humblebees, Jacob actually came to see me and tell me what had happened. For my sake he prevented any one killing the parents, and the dear little things reared their brood safely in the corner of the old Obi man's compound, What splendid colouring there was 


\section{Stray Leaves from a Border Garden}

in that neglected spot! A more considerable house than his had formerly stood there, and there were tall green-andcrimson-leaved "Dragon's-blood," which I scarcely recognised for the tiny pot-plants English gardeners cherish in greenhouses; green and yellow parti-coloured Crotons, slim-leaved Aralias, a multitude of twining Vines and scented Orchids and "Morning Glories," with their gorgeoushued purple and pink cups, and in one corner Datura with drooping white bells. Jacob was amused at my raptures over the mass of Maidenhair Fern in the dividing ditch by the road; it did not represent much to him. At last, by dint of many visits, he so far opened his heart to me that I discovered the old man's heart was away in the wilds of Panama with a son who, attracted by the high wages offered by the Frenchman to whoever would come and labour at the Canal works, had with other young West Indians gone off to Colon, and no news had come of him! At last I wrote a letter to the clerk of the works there in hopes of finding out what had become of the poor old fellow's son. Curiously enough, he seemed more wrapped up in this one absent boy than in the three who lived with him. But there came no answer. At last one day the maids came and asked permission to go to old Jacob's for a dance. "Why is he giving a dance?" I asked, and was told that his son had come home unexpectedly from Panama; so Rosa and Lily, and Mussoo and Queenie were all going down in their brightest cotton dresses, with their woolly pows elegantly bedecked with ribbon and flowers, and surmounted by hats covered with white feathers, to help Jacob and his family to make merry. They came home late in the evening, along by the river, in the Firefly-lit darkness, clinging together for fear of "duppies," laughing and chattering.

The next day I saw the hero of the fête, a tall, wellbuilt negro, dressed in coloured shirt and grey trousers, and sporting a fine watch and chain, which old Jacob told me had been given to him by an official he had nursed through a bout of fever, that weary malarial fever which 3 I 8 


\section{My Friends in their Gardens}

has swept away so many of the European workers on the Canal. He had a little money in hand too, but this did not last long, and I heard shortly afterwards he had enlisted in the West India Regiment quartered in the neighbourhood. Once a rover always a rover; he could not settle to the quiet life led by his brethren, and even the prospect of going to the far-off West Coast of Africa did not deter him, as it does many West Indian negroes. The following year I happened to be staying in the neighbourhood and missed old Jacob from beneath the Horse-eyetree. The hut was deserted and the family gone. Not a negro would pass the spot, and report declared the place was haunted. The vines and bush had shot up high and luxuriant, and snakes glided to and fro among the leaves, Jacob was dead. 


\section{OUR LADY OF ROSES}

WE called her so to each other-we, the old Rector's motherless daughters, who were privileged to come and help her when, as sometimes happened, she gave school feasts and the children of the parish ran riot beneath the splendid old Elms and Beeches of the Court. We recalled how our father remembered her coming long ago as a fair and gracious young bride to the old red-brick house by the sleepy brown river to brighten with her fairy touch the dim old rooms and bring peace and plenty to the village; how in poor years she had found work for the labourers by planning first a piece of clear ornamental water where whilome had been but a muddy brook. Then a Rosery was made in the grass lawns that stretched like a green mantle near the dark Cypress-tree walk, and amid Rosehung arches tall white Madonna Lilies raised their stately heads. And year by year the garden grew in beauty by the sedgy lake with its Waterhens and Swans, the Polygonums and giant Burdocks she had planted grew tall and branching, and the starry Jasmine and Roses up the old house grew thicker. In the beds of the red-walled kitchengarden she collected old-fashioned flowers-Cabbage-roses, Musk-roses, and the White Roses dear to Prince Charlie, scarlet Bergamot and Turncap Lily, blue Thistle and plume Poppy. Her fruit-trees on the walls were devastated by the many Squirrels who boldly climbed over and sampled the swelling Apricots unchecked by the Gardener, who dared not destroy the winning little thieves. Our Lady would not have them harmed. The Blackbirds nipped her Pinks, 


\section{My Friends in their Gardens}

the Sparrows likewise broke the Gardener's heart, and though she grieved she would not do away with either feathered villain. How I loved to walk with her beneath the avenue of old Linden-trees, where the Bees haunted, humming; outpouring youthful troubles, and the sometime heart-weariness of a motherless creature, to be soothed by the tender grace and abundant sympathy of my Lady! I think she bore about with her the crystal amulet which, according to the old story, compelled the love of every one who met with the wearer, who, dear sweet soul, went through a perilous world unscathed and all unconscious of the charm she bore. I remember the old mossy Bowlinggreen, with its fantastic Yews cut into bird and beast shape, where the blue-necked Peacocks used to trail their gorgeous fans or mount and preen themselves on the low stone balustrade of the terrace. My Lady would walk up and down the terrace and watch the old weathercock on the top of the tower with anxious eyes when the wind was rising : she had a boy at sea.

The elder son was married, and lived quietly amid his Turnip-fields in the neighbourhood; the younger, his mother's darling, was a restless soul, and loved the life of a sailor. But every now and then he would return home, and then my Lady would walk so proudly with him in the old walk between the Holly-hedges (where they had walked together ever since the days when in the holidays he was wont to confide his schoolboy-pranks to his mammy), she leaning now on his arm, where formerly, so the old folk about remembered, the pretty young mother used to entice the scarcely running child to follow her along the path by deftly-thrown ball. And the Squirrels frisked away before them as they had done times without number, and the chuckling Blackbirds and bold Robins haunted the path and stopped on the close-cut hedge to look at them. My Lady loved them all, and they knew it. 


\section{CORBIE HALL}

THE March of Progress is, no doubt, a thing to be admired, and loving one's fellow-men, no doubt one should rejoice in civilization, which brings all men more on an equality ; and doubtless, when we shall all live in mediocre one-brickthick little red houses, with duplicate squares of garden, and the old mansions of the countryside have all been swept away to allow of the lands being equally divided, it will be very desirable, yet scarcely beautiful. Corbie Hall was one of these old mansions. It had been built by a Border Laird, whose habitation had been burnt over his wife's head in the ' 45 , while he was away with Prince Charlie. The lady had escaped, and in later days, sitting by her fireside in her townhouse in Edinburgh, had been wont to tell how she had had the honour of dancing with the Prince in the halls of Holyrood, showing a dainty satin shoe once white in proof thereof. It was a grey stone house without portico, but with a large entrance-hall full of old pictures of beruffled knights and silken-clad ladies. In the old panelled drawing-room with its "Adams" ceiling there were bits of quaint old furniture-Chippendale orSheratonwhich would have delighted a connoisseur, while on the tables and mantelpiece were joys in china which modern care would have secured in glass cupboards for their value, but which were here allowed to remain freely exposed to the housemaid, that personage only less destructive than the illfamed proverbial cat. The old Laird had made the Grand Tour in the days when folk travelled leisurely in their own carriages, instead of tearing over foreign lands at the tail of 


\section{My Friends in their Gardens}

a teakettle, as our modern progress has been irreverently described, and sundry inlaid caskets, and notably a round table cunningly formed of a multitude of coloured marble bits, bore witness to his appreciative taste. But he had refrained from putting unclad nymphs among his garden glades, and the old garden looked as it might have done when his ancestor entertained Mary Queen of Scots. It is evident that charming queen must have spent all her time travelling, since nearly every Scottish gentleman's house seems to have seen her, as guest or prisoner! I do not know whether the old Bowling-green-lovely green velvet lawn that it was!had been actually pressed by the fairy foot of the ill-fated beauty, but since the old place had belonged to a faithful adherent of hers, and she is said to have visited it in her earlier and happier days, she and her Maries may have played hide-and-seek in and out among the devious Hollyhedges of which but a few now remain in the pleasaunce so ancient, bird-haunted and well kept. Certain it is, a bed of Angelica is said to have been planted by Mary, who is likewise credited with having introduced several other herbs into Scotland. In those days Angelica stalks were eaten as we now eat Rhubarb, or blanched and eaten like Celery. In Lapland they are still appreciated in this fashion, and in Longfellow's saga of King Olaf, the king brings his bride Angelica stalks.

There was a Nut-tree-alley, too, of Spanish filberts, planted, so the legend ran, by the Spanish bride of some Laird long since dead, who had faded away beneath the colder sun of the northern clime, but who had left her name to the Lady's-walk and a silver reliquary to the curio-table in the Green Drawing-room. The number of lovers that walk had seen! It was the most sheltered walk in the garden, and just sufficiently apart from the Bowlinggreen to render it certain some of the players would be for ever straying away. When I knew the old house, Darby and Joan (to speak more respectfully, the Laird and his Lady) often walked there, though the strength of his youth had left the Laird's arm, and the man who had led forlorn 


\section{Stray Leaves from a Border Garden}

hopes and storming parties had now not even strength to throw the jack. But still they frequented the Nut-alley and crept arm-in-arm along in the sun, Joan with her silvery hair and ivory complexion, and Darby erect and tall, like a withered oak of the mountain-side, with the piercing blue eyes, that had cowed the mutinous sepoy, dwelling fondly on his beloved. One hears a great deal about the loves of youth, but I think there is great beauty in the faithful affection of years, when a pair of lovers are spared to grow old together in the nest of their young love. There was the Myrtle, sprung from a sprig of her bridal bouquet she had planted, now grown a tree against the Greenhouse-wall, and the Lavender-hedge the children remembered as long as they could remember anything, and the bed of White Lilies they had called Mother's Lilies all their young lives, and now the grandchildren pervade the old garden, and learn the names of the different corners and speculate in the Pugs' Cemetery, a secluded glade where numberless pugs and terriers have their little lives commemorated by mossgrown stones with Chloe, Tom, or Sambo cut upon them. Farther away was the lawn where in past days triumphs of archery had been won; Grandmama's old bow still hung in the hall. Now the scattered Snowdrops were no longer disturbed by the falling arrows, and croquet was the pastime of the hour. How beautiful the Laburnums were along the avenue beneath the dark Scotch firs and spreading beeches !- "Golden-rain" seemed such a good name for them, even when the drenching Scotch rain sent their shining petals drifting in all directions. I had always thought the Laburnum only fit for a villa-garden, but after seeing Corbie Hall with Laburnums in the strips of plantation which bordered so many of its fields or " parks," as the Scotch call them, I began to admire them and think they were distinct adjuncts to the stately Firs and graceful Larches. The Broom, too, were so beautiful on the outskirts of the plantation, and the Sweetbriar in the lane that led to the Knight's Croft, which in the Spring was just one mass of white Bird Cherry, and even after my old 


\section{My Friends in their Gardens}

friend could not walk as far as this, her favourite lane, she would send her grandchildren to gather great bunches of the Sweetbriar to fill her graceful glass vases. How fond she was, too, of Solomon's Seal! -Our Lady's Signet she used to call it.

There was a great circular clump of that most graceful of flowers in the old garden which had been there from time immemorial, and she cherished it as the apple of her eye. None of the gardens of the neighbourhood could boast a similar treasure. Then there was the Holly-arbour, which in the Springtime was full of nests, with a favourite bed of blue Iris close by ; and the walk where the White Rose grew, which was said to be the real old Jacobite Rose, the presence of which formerly in a garden betokened that the owner loved Prince Charlie, just as to this day you can tell in Ireland where an Orangeman lives by the Orange Lilies cherished in his garden-plot. Some flowers look as if no interest can attach to them-notably Tulips, I used to think; but after hearing one bed of these gorgeous flowers beneath a high red-brick wall always referred to as "old Mrs. Brown's Tulips," I confess to having a certain tender interest in these flowers, planted long ago, as I discovered, by a lonely old lady who at one time had hired Corbie Hall for a few years from its owners. Then there was the Rock-garden, where were cherished many little varieties of Ferns - the Crested Holly, Parsley, and Hay Ferns, and a tuft of sweet-scented Swiss Pinks, a keepsake to grandmama from a Swiss mountain-side, and in one corner a plot of grass with an old mossy sundial with the motto, "Count the sunny hours." Mrs. Brown's advent was the beginning of the end. Rents went down, and it was no longer possible to keep up Corbie Hall, and the tenants lived to see their beloved Laird and his Lady in their old age go away to the great city which swallows up all the unfortunate, and the old place stood empty for a while with a board "To Let" on the great stone gateway. And since this is an ower true tale of the Borderland, I cannot say, as I should like to do, that they came back rich and prosperous, and ended 


\section{Stray Leaves from a Border Garden}

their days in the old home of their fathers, but, alas! that the Laird's blue eyes closed on the London chimney-pots, and successive Edinburgh writers battened on the old place, men whose grandfathers, had they boasted any, would scarce have been deemed worthy of being horse-boys to the Laird's ancestors at Flodden or Bannockburn. But the old order changeth, giving place to the new, and it may be this upturning of the soil is for some good, though I confess, when I see the rag-and-bone merchant who now lords it at Corbie Hall in the place of mine old friend, I long for a blast of the magic flute which sent every man to his own place. 


\section{PADRE AVELINO}

I HAVE always loved flowers, and some of their familiar faces have been as friends when seeing them unexpectedly in far lands, even though the branching Geraniums or giant Aralias have looked rather different from the puny specimens of their kind I had been accustomed to see at home in Europe. On the other hand, I have seen tears fill the eyes of a West Indian on seeing a pile of Cocoa-nuts in a grocer's shop in a poky little Scots town. To others it was only a pile of dingy brown nuts in a window full of miscellanies; to her it was a recollection of a sunlit shore where similar nuts hung from graceful palms, and the sound of snowy surf breaking for ever on the golden sand was again in her ears. Oh! the power of association; it is the magic wand of the rainbow-clad Fay, Memory. I chanced to find myself in Trinidad, it does not matter why or wherefor; we all have our heartaches at times, and our ways of dulling them. I was staying with an old Scotchman, a doctor, who, although he had lived there some twenty years, yet spoke as though he had only just left Edinburgh, and cherished me, a stranger commended to his care, with double tenderness when he found the latest soil I had trod in Europe had been that of Auld Reekie. "I long to feel again the East wind that blows so fresh along Princes Street," he said, sniffing with disdain the languorous breeze, heavy with scent of Orangeflower and Stephanotis, which blew in at the open window of his little sitting-room. "Why not go there?" I said. But he shook his head. He had talked of going home for many years, he would probably continue to do so, and never 


\section{Stray Leaves from a Border Garden}

go at all. I wondered what was the tie that prevented him. I did not reckon with the mighty force of habit. I stayed with him about a month, helping him in his work and dis. covering thereby how much he did amongst the poorer classes for pure love, apparently, of his fellow-creatures. He was not much of a talker ; he would sit smoking his pipe in the verandah at night, watching the Fireflies circling in the ambient air, and dropping dry pithy remarks. One night he said after a long silence, "Airchie" (he had discovered my name was Archibald), "Airchie, my mon, I'm thinking I should not let ye leave the island without seeing the Padre" "The Padre?" I said, rather surprised, as, although I was not exactly acquainted with the form of religion professed by Doctor Gordon, I somehow could not fancy his lank red-haired personality in touch with what must evidently be some fat friar, shepherd of some dusky flock. "Ay, Padre Avelino; he's a man, he is. I've known him since I drifted here years ago, without a friend to my name." He paused and took a whiff at his pipe, then added: "He nursed me through an attack of Yellow Jack that was like to have carried me off. Not because he was acquent with me; no, because I had nobody to do a hand's turn for me." A few days afterwards Dr. Gordon suddenly announced to me he was going to take me a long ride into the country. We started in the early dawn, a pale pink flush was spreading over the sky in the distance above the mountains, what somebody calls the "rosy fingers of Aurora opening the gates of morning to the Sun's chariot." There was a chilly feeling in the air, but on my complaining, Dr. Gordon said, with a grim smile, "Hoots, ye'll be hot eneuch later. Dinna fash yersel'." The Doctor's old grey house, with its tall doorway and deep portico wreathed with the flaming flowers of the Venusta, was situate on the road to the Botanic Gardens, in a sadly dirty street where stray dogs, ungainly black vultures called "Corbeaux," and soft-eyed goats roamed at will, along with leggy chickens and endless children, halfclothed but shining with grease and cheerfulness. We hurried on, past wretched wooden sheds, the habitations of 


\section{My Friends in their Gardens}

poor folk, and better-looking houses, likewise of wood, painted gay colours however, buried in luxuriant trees and bushes, and enclosed within high walls, over which hung masses of flowering Creepers, Trumpet-flowers, Blue Peas, and what seemed Convolvulus of different colours. I asked the names of some of these gaudy but ephemeral-looking beauties as we sped along, but the Doctor was no botanist : "Jist weeds," was all he would say; adding, "Bide a wee, the Padre will tell you." At last we were away far beyond the outskirts of Port of Spain, and in the woods, following a lonely road-" trace," the Doctor called it-up into the spurs of the mountains, with occasional peeps of purple sea far away. There is something very beautiful about a tropical forest, with its vast variety of trees, all interlaced by lianes of varied thickness like green cordage, starred with flowers, and green with an emerald-green richness which, painted in a picture, would be deemed unnatural by the folks at home in the old country. One thing struck me : at home the forests seem mostly to consist of one, or at most two kinds of trees, here in the tropics no tree resembles its neighbour except when Coco-palms rise in their soldierly lines near some habitation. The road was very lonely, we met no one except once a troop of black and brown men dragging a rough low cart with painfully creaking axle, called a " diabe," or devil, the Doctor said, on which was mounted in state a canoe. They were all singing in unintelligible patois, and a small boy seated in the canoe was beating a very primitive-looking drum as a sort of accompaniment. We heard the echo of their din long after they were out of sight. At last we came to a cluster of small wooden cottages on the edge of the wood, each with its patch of provisionground full of vegetables of sorts, and a few Orange-trees laden with fruit, a Breadfruit-tree, and, of course, the usual collection of dirty, half-naked children playing about the doors of the huts, and on the steps of the tall white crucifix that, somewhat apart from the road, seemed to keep watch over the hamlet. There was a small white painted church close by, and round it a bit of enclosed ground partially 


\section{Stray Leaves from a Border Garden}

shaded by two or three tall Palmistes. A sound of music stole out of the open windows of the church; evidently some one was practising on a harmonium within. Near the church was a small wooden house painted yellow, uplifted, of course, on short red-brick pillars. By the door was a great clump of Crotons and a tall old crimson-leaved Dragon's-blood bush, and the house itself was almost hidden by mauve Bougainvillea. Just as we rode up a tall, finelooking man, dressed as a Catholic priest as to his upper garments, but with gaiters on his legs, came out. He looked delighted to see my companion, and welcomed us with great cordiality, speaking the curious French patois which seems to be the most universal language in Trinidad, in spite of its Spanish history. Dr. Gordon introduced me. " Here, Padre, here is a countryman of mine come to see what like Treenidad is." "As my friend's friend, I make you welcome, mos' welcome," was the priest's reply in fairly good English, with, however, a little accent which I afterwards discovered to be Spanish. He took us in to have some refreshment, into a room evidently his sole sitting-room, with polished floor, folding-doors of latticed wood; some jalousies were open at one end, and kept from swinging-to by large conch shells with pink lips. I saw the priest's bed beyond with snowy mosquito-curtains and ivory crucifix beside it on the wall, where also I noticed several devotional prints. The furniture seemed scanty-two chairs, one polished with long use, a shelf full of books, mostly Spanish; I forget their names now, only I know there was a Don Quixote, that quaint pathetic old classic, and a tattered book on Botany in French had been most carefully mended, and the Life of St. Francis of Assisi, the lover of animals. The two or three others looked to be theological.

A most hideous old negro woman, with a very gay turban, brought us some most delicious coffee, a bit of salt meat, and a plateful of yam. As she put these down the priest, smiling, said to Dr. Gordon: "I know what monsieur your friend will be wanting if he is new to the island." $\mathrm{He}$ left the room, and presently returned with a square 


\section{My Friends in their Gardens}

inlaid tray of dark polished wood heaped with oranges and bananas and a mighty sweet-scented shaddock. While I enjoyed these my host and the Doctor discussed the politics of the island and the little local interests, in which I did not feel interested, especially as every now and then, forgetful of me, they broke into patois. Presently the Padre, as Dr. Gordon called him-Father Avelino I learnt was his name- - said he would show me his church. "And your garden," interpolated the Doctor. The priest nodded. So we sallied forth to the pretty little church whence the music was still sounding. Here we found a dark-eyed, lovely brown girl practising, on an ancient harmonium woefully in want of tuning, the music which on the following Sunday was to delight the music-loving parishioners of the Padre! She rose when we appeared, and in response to the priest's greeting she smiled, showing exquisite teeth, and answered in that soft-sounding patois which is so delightful to hear, even if one does not understand the words spoken; indeed, they are not spoken, they are sung. The church was neat and clean, but, like all Catholic churches, empty of pews; a few chairs only about, several altars, the floor well worn before them, especially before the Virgin's. Here two old negresses with straw hats surmounting white turbans (a sign of mourning) were kneeling, a dog lay curled up beside one of them. Ex votos hung from the ceiling : a dusty little ship, a turtle-shell, some crutches, and in one corner I noticed what appeared a wedding-wreath carefully enshrined under glass.

The priest observed my glance: "Yes," he said, "poor girl, I married her, and two months afterwards she died of yellow fever. Her husband hung her wreath up there." "Poor things!" I said sympathetically ; "what became of him ?" "He married again," replied the Padre, a trifle drily. Then, saying there was nothing more to see in the church, led the way out into the blazing sunshine, which seemed doubly garish after the subdued semi-darkness of the church with its two or three twinkling votive tapers. "Noo yer garden, Padre," cried Dr. Gordon; " noo for 


\section{Stray Leaves from a Border Garden}

your family." "Yes, my beloved family, my flower-children; but they do not need much cherishing in this country," said Father Avelino, smiling. "I remember in Guipuscoa" -but he checked himself with a sigh.

$\mathrm{He}$ opened an iron gate half hidden under a mass of Trumpet-flower in a wall and took us into such a little garden of delight as I remember still in my dreams, but shall never see or smell again. The walls were covered with tangled Creepers which reminded me of the morning glories in my old mother's garden long ago, but idealised in beauty to an extent I had never dreamed of, and the Padre, pointing to each beauty in turn, named each (its Latin, and its common name, if so be that it had one) till I felt fair bewildered with hearing of Tacsonias, Echites, Ipomeas, Bignonias, \&c. \&c. Indeed, I despair of bringing the beauty of that little enclosure before any one by mere description. What does the word Allamanda, for instance, represent to some folk? A small bush with cuplike flowers, sprays of which sometimes appear on the dinnertables of rich people; here it was a big bush with masses of flower-laden sprays, little thought of, growing amid a hundred others as striking in appearance. In one corner was a tiny red-brick shrine, surmounted by an iron cross, cracked with age, painted within blue with golden stars, containing a Virgin carved in stone, holding the Child on her hand! - a thing you do not often see. The shrine was almost hidden by great bushes of scarlet and white heavyscented Ixoras, and overhung with crimson Passion-flower and Roses. In the branches of the tree overhanging it, a tree somewhat like an Acacia, whose name I forget, the Padre, pushing aside a bough gently, showed us a Hummingbird's dainty, cosy nest with the little bright-eyed birdmother sitting fearlessly on it. "I come by every day," he explained, "so she is not afraid of me." Her mate, like a living flash of sunshine, darted above our heads. Across the path ran a little green lizard ("zanoli" the Padre called it) and disappeared among the Ferns, which grew thickly at this spot, intermixed with pink and white 


\section{My Friends in their Gardens}

Begonias and the red and yellow coarser blossom of the Ipecacuanha.

Bauhinias, Crotons, and several tall green Dracænas were also here, and on one side a repellent-looking hedge of blue-leaved Aloes and "Spanish bayonet " kept intruders at a respectful distance. Close to this hedge were some Gardenias and Arums, whose white flowers the priest said he used for decking the altars. In the midst of the garden an Orange-tree and a giant Magnolia shaded a wooden seat where, so Dr. Gordon said, the Padre sat and interviewed such of his flock who came to seek his advice and good counsel, and even while he spoke the old negress came and said some one wanted the Padre. So he went along the path bordered with tall red and yellow flowered Hibiscus to the narrow wooden stair and disappeared up it into the house, while we sat down beneath the "tonnelle," and Dr. Gordon told me the story of the Padre. "Ye would not, maybe, think it of him, but he has not always been a parish priest. $\mathrm{He}$ was a guerrilla chief, a Cabeçilla in Spain, a Carlist, who at last found his native sierras too hot to hold him. He was obliged to fly the country, and he came here, and now he passes his days visiting the sick and poor and afflicted. He was up all last night with a sick negress, and will be again likely to-night. His provision-ground helps to feed many a ne'er-do-well, and he is as wise in knowledge of herbs as any old Obi-man or quimboiseur around. 'Deed, as to medium, I tell him he's just a poache !"

"Will he ever go back to Spain ?" I asked, watching the Butterflies as they skimmed to and fro in the sunshine. "I could not say. I doot he'll be well missed if he does." At this moment the Padre reappeared. "I grieve, my friends," he said, " to have to leave you; but Mahme Séraphine at Anse Joseph is very ill, and cries for me. I must go." "You must go!" repeated Dr. Gordon, sarcastically adding to me: "She's just an old quimboiseuse, said to have poisoned a good few folk in her day. Among others, Father Jean, who was here before the Padre. 


\section{Stray Leaves from a Border Garden}

Now she has taken a notion that ' his magic,' as she puts it, is stronger than hers, and she thinks the 'Zombi,' who has laid his evil finger on her and is crushing the life out of her, may succumb before the White Padre. But it's not unlikely she may think to propitiate the Zombi with the Padre rather than herself. I would not go nigh her if I were him!" But the priest only smiled, a curious inscrutable smile, when Dr. Gordon, waxing warm and talking very broad Scotch in his unusual excitement, tried to dissuade him from going. $\mathrm{He}$ mounted his big white mule, looking a queer figure with his cassock tucked up and ending in hide gaiters and heavy boots, armed himself with his machète, a very ugly-looking cutlass, to use, however, on nothing more dangerous, we hoped, than the firmly twisted lianes of the "Grands Bois," or the Patate bòlanmè or Sea-vine, and rode away from us, past the big wooden crucifix with its life-size figure, painted flesh colour, with painfully realistic blood-drops and gilt crown of thorns, away into the high woods, bound on an errand by the side of which facing the royal soldiers on Spanish mountain slopes had been a trifle. For there's many a man will stand up and face a rain of bullets who would hesitate to go where death may lurk in a glass of water, and he may never return from his errand of mercy. But of such dauntless hearts the Church Militant here on earth counts many among her soldiers. "Yon's a good man if ever there was one," remarked Dr. Gordon as, having seen the last of our friend, we prepared to return home. "Do you belong to his persuasion?" I asked hesitatingly. "No, no, lad; I'm no Roman. But I will say that for them, they would win more influence over the nigger than any other set of devil-dodgers I know. Reason why, let wiser folk than George Gordon tell." 


\section{LITTLE REINE-DES-CIEUX}

"I LIKE that ancient Saxon phrase which calls the burialground God's-acre," so sings a poet whose name will long live enshrined in the hearts of all English-speaking people, and as I write comes back to me, clear through the mist of years, a very God's-acre, a "fair garden" on a far-off Swiss hillside, where the country-folk of a quaint little lonely village laid their loved ones to rest. It was but a cluster of low brown châlets-Val Ste. Croix-with the roofs borne down by heavy stones to help them to defy the mountain winds, and jutting eaves, so familiar now to English wanderers in that playground of the nations, texts carved over the door and windows in queer old letters and strange unfamiliar Swiss-French: "Except the Lord keep the house," \&c. Goats haunted the doorsteps, and little round-capped maidens herded them. There were quaint old grandmothers with distaffs and gaffers with velvet waistcoats and silver buttons, and wooden shoon; the banished Pigeons circled about the roof, and by each house were rows of Beehives. Some distance away, at one end of the little village, was the church, a white-painted unartistic little building, where, beneath a heavy-looking sounding-board, dome-shaped and black with age, the old pasteur held forth weekly to his congregation. Beyond again, up among the lush hay meadows, was the churchyard, or rather cemetery: a small square plot of ground studded with small black wooden hearts, some having names inscribed on them, and others denoting vacancies by blanks. Over the door was painted in white 


\section{Stray Leaves from a Border Garden}

letters a text: "It is sown in corruption, it is raised in incorruption." The grass grew long in the God's-acre, and the Poppies and rosy Saxifrage flourished; it might have looked neglected but for the flowers. The golden Gentian grew there too, "Candles for the Dead," said little Reinedes-Cieux," the sexton Leblanc's orphan grand-daughter. She called the purple Campanulas Bells-Clochettes-and declared the angels rang them when any one was coming to his rest. She said falling stars meant passing souls, and she supposed more souls died in the Autumn, because this world was triste then. Over her head the infidel schoolmaster murmured, "It is the month for suicides, November "; and added, "She is not all there, the petite." She haunted old man Leblanc's footsteps whenever he dug a grave, and always threw a bunch of sweet herbs in before the coffin took possession, never failing to put a bouquet on the mound afterwards. Her mother had been an Italian-Swiss, and Reine seemed to have inherited from her alien parentage a feeling for flower-decked resting-places, foreign to the Swiss of that northern valley. Reine's parents were both dead; her father had been a guide in the mountains and had fallen a victim to the insatiable passion of the stranger for Edelweiss, and his young wife had not lingered long after him.

Reine was an odd-looking little mortal with dark eyes and yellow hair. She used to haunt the village inn during the short Summertime with tiny basketsful of Wood-strawberries or Mountain-raspberries, and bouquets of delicate Pyrola and wild fringed Pinks, Gentians or blue Geraniums, which I used to buy from her. Then in the evening, when I wandered, as I often did, to the hillside slope above the cemetery to see the sun set, I would see the little red petticoat and white cap flitting about below me, and I would know that Reine was picking flowers "for mother," as she phrased it. Poor little Reine! When I revisited the mountain-village some years later the little quiet inn had given place to a new-looking boarding-house, "Pension des Anglais-Villa Bellevue," written over the green door in 


\section{My Friends in their Gardens}

large white letters, and an omnibus jingled twice daily across the tiny village square, where the purple Pigeons had been wont to haunt about the stone fountain fearless of the women who came for water. I asked for Reine. Alas! her name was now marked on a little black heart-shaped slab. A small playfellow had fallen off a loaded hay-cart, and in trying to save him Reine had fallen under the wheel and been hurt unto death. By her heart there grew a tall yellow candlestick of a yellow Gentian, and I cast on the little grassy mound a bunch of favourite blue Gentians, blue as the eyes of little Reine-des-Cieux herself, or as the far-off sky, where, as she had once told me, surely the good God plants the hearts he loves in the flower-fields of Paradise. 


\section{MISTRESS BELL}

"Mistress Bell's at home." No one ever heard otherwise who called at her house. She had spent nearly thirty years in that house-she never left it-in that room I was going to say, but she was wheeled into an adjoining bedroom to bed, and that was all. She sat for ever in an armchair by the window, from which she could see out into the courtyard and watch the sun set behind the old Lime-trees, and see whoever came or went. She confessed to a frank pleasure in the coming and going of people to the house. These were many, as Mr. Bell was factor to many neighbouring gentlemen, and was busy and popular to an uncommon degree. She knew every bit of current news, but gossip, and even scandal, when it came to Rosebank, was somehow purified before it went any farther, and became innocent friendly interest.

Nothing could go on in Mirelaw without coming to the knowledge of Mistress Bell, and her gentle censorship was doubtless cause that the Black Sheet was less black there than elsewhere in Sheriff Hume's jurisdiction. More marriages were celebrated there than were, alas! deemed necessary in neighbouring parishes, and obdurate cases were brought to her by parson, minister and priest alike, to be vanquished by her in the power of that love which enwrapt her like a mantle. I can see her now, sitting up in her big carved chair, her keen, clever face all alight with interest in the topic of the moment; she was not beautiful, except her eyes, which were clear like limpid brown backwater, and full of soul. 


\section{My Friends in their Gardens}

You were sure of sympathy from her, whatever were the woe : a pet canary fluttering into the fire, or a son gone to the bad, no one ever came to her and went away empty. She read a good deal, and worked wonderful embroideries, which always eventually disappeared. I fancy they helped to keep filled a certain heart-shaped painted box she called her "charity purse," and which seemed a perfect widow's cruse. She took a great interest in flowers and birds, and Mr. Bell hung for her on the window Cocoanuts, whereby the Bluecaps disported themselves, to her great delight. He had even put up a tiny platform by the window, where Robins and Thrushes came and fed. One Robin, indeed, lived in her room in winter, and seemed quite at home there. But with the Spring days he took to flying in and out, and lived more in the Rose-tree which climbed up the side of the house. When I knew her he had been a regular Winter visitor for two years-a handsome, bright-eyed fellow, who seemed perfectly fearless.

I think of her when the Lime-trees flower, for it was then I first made her acquaintance, through the accident of my pony-carriage coming to grief in the paved streets of Mirelaw. Constrained to wait while the damage was being remedied at the smiddy, the blacksmith suggested I should take refuge just across the road at Rosebank. I had heard of Mr. and Mrs. Bell since my coming to the neighbourhood; I knew their employers. I plucked up courage to face the unknown, and went in at the ever-open iron gate with its great stone pillars, the old-time county town house of some local worthy. The Bluebells in clumps under the Limes were dying down, the Lime-flowers were beginning to show, and the Bees were humming in the branches. The house was thickly covered by a great Gloire de Dijon Rose, and a bed of Mignonette under one window scented the air. I noticed a queer little square looking-glass hung outside, near the same window. I found out afterwards it was a Dutch "spionnen," one of the double glasses arranged in the Dutch fashion, to reflect all that passed outside for the benefit of the poor prisoner within. A smiling country 


\section{Stray Leaves from a Border Garden}

lassie introduced me, and Mistress Bell of her old-world courtesy so made me welcome, I was surprised when they came to tell me my carriage was ready for my homeward progress.

But after that I came often in the Summer, when she joyed in her Roses and Mignonette; in the Autumn, when she watched the dead leaves circle around the courtyard, and cherished the last lingering Asters; in the Winter, when the window was closed and the Robin within sang her a song of Hope from the top of the cornice. She had flowers within, however; she nursed Geraniums, and they flourished with her as though she had been an old cottager's wife, blooming as though they knew they must be always ready to give her the pleasure of offering bloom and scented leaf to her visitors. But, alas! the time came when no tale of uttermost woe could move her ; still and fair, with the beauty of youth come back to her aged face, she rested from the weary task of waiting Heaven had set her: "Those also serve who only stand and wait."

Those she had comforted and befriended gathered beyond the gates by the old grey church to show him she had left that none would willingly omit the last honour they could render her. That was long years ago. I revisited Mirelaw the other day, and, going as a stranger, was shown the old house, its title to honour being: "Yon's whar oor gude Mistress Bell lived. We've no seen her like again, an' we winna!" 


\section{Handbooks of Practical Gardening}

Under the General Editorship of HARRY ROBERTS

Crown 8vo. Illustrated. Cloth, 2s. 6d. net.

The following Volumes will be published during the Spring:-

VoL. I.-THE BOOK OF ASPARAGUS. With sections also on Celery, Salsify, Scorzonera, and Seakale; together with a chapter on their cooking and preparation for the table. By Charles ILOTT, F.R.H.S., Lecturer on Horticulture to the Cornwall County Council.

VOL. II.-THE BOOK OF THE GREENHOUSE. With a special chapter on the little Town Greenhouse. By J. C. Talzack, F.R.H.S., Head Gardener at Shipley Hall.

VoL. III.-THE BOOK OF THE GRAPE. By H. W. WARD, F.R.H.S., for 25 years Head Gardener at Longford Castle; Author of " $\mathrm{My}$ Gardener."

VoL. IV.-THE BOOK OF OLD-FASHIONED FLOWERS. By HARry RoBerts, Author of "The Chronicle of a Cornish Garden."

Other Volumes in preparation.

JOHN LANE : LONDON: VIGO STREET, w.

JOHN LANE : NEW YORK: 25 FIFTH AVENUE. 


\section{BOOKS ABOUT GARDENS}

Seven Gardens and a Palace. By "E. V. B.," Author of "Days and Hours in a Garden." Illustrated by F. L. B. GRIGGS and Arthur Gordon. Crown 8vo. Price 5s. net.

Third Edition.

"A charming companion for a leisure hour." (World.)

"Altogether a pleasant and fragrant book, with something of the sense of lavender about it." (Review of the Week.)

The Chronicle of a Cornish Garden. By Harry Roberts. With Seven ideal Illustrations by F. L. B. Griggs. Crown 8vo. Price 5s. net.

" 'The Chronicle' is written in a frank unaffected style, and will suggest useful ideas to other garden lovers." (The Literary World.)

"It is written with grace and knowledge, and will please as well as teach." (Bookman.)

A Garden in the Suburbs. By Mrs Leslie Williams. With Eight Illustrations. Crown 8 vo. Price 5 s. net.

Stray Leaves from a Border Garden. By Mrs Mrlne-Home, With Eight Illustrations by F. L. B. Griggs. Crown 8vo. Price 6s. net.

My Vicarage Garden. By Canon Ella. COMBE, Author of "In a Gloucestershire Garden," \&c. With Illustrations by F. L. B. Griggs. Crown 8 vo. Price 5s. net. In preparation.

JOHN LANE: $\begin{aligned} & \text { LONDON: VIGO STREET, W. } \\ & \text { NEW YORK: } 255 \text { FIFTH AVENUE. }\end{aligned}$ 


\section{BOOKS ABOUT GARDENS}

In the Garden of Peace. By Helen Milman (Mrs Caldwell Crofton). With 24 Illustrations and Cover designed by EDMUND H. NEw. Crown 8vo. Price 5s. net.

"Sincerity is the note of the whole book." (Globe.)

Outside the Garden. By Helen Milman (Mrs

Caldwell Crofton). With 24 Illustrations and Cover by EDMUnd H. New. Crown 8vo. Price 5s. net.

" 'Outside the Garden' fully maintains Mrs Crofton's reputation as one of Nature's keenest observers." (Daily Chronicle.)

\section{My Roses and How I Grew Them. By}

Helen Milman (Mrs Caldwell Crofton). With a

Cover designed by EDMUND H. NEw. Crown 8vo. Price Is. 6d. net. Third Edition.

"Pleasantly written. . . The book is such that a novice might implicitly follow, while the more experienced may find useful hints."

(Garden.)

Flowers and Gardens. By Forbes Watson. With Photogravure Portrait of the Author. Edited, with a Biographical Note by Canon ELLACOMBE. Crown 8vo. Price 5s. net.

A reprint of a volume much sought after by garden lovers, which has been out of print for many years.

"I am afraid Dr Forbes Watson's most charming book 'Flowers and Gardens' is too little known. No modern author, not even excepting Ruskin, has studied the form and the beauty of flowers so closely and lovingly as be has done." (BRIGHT's "A Year in a Lancashire Garden.")

A book "which was once warmly welcomed and which appealed immediately to all readers by its charming style and beautiful thoughts."

(EllacombE's "In a Gloucestershire Garden.")

The Birds of My Parish. By E. H. Pollard. With Collotype Illustrations. Crown 8vo. Price 5s. net.

"Evelyn Pollard has a very delightful style of writing, and the story of the Birds of her Parish is charming." (Shooting Times.) 


\section{BOOKS FOR COUNTRY HOUSES}

\section{The Natural History of Selborne. By}

GILBERT WhITE. Edited, with Introduction, by GRANT ALLEN. With upwards of 200 Illustrations by EDMund H. NEW. Fcap. 4to. Price 2 Is. net.

"The most delightful form that can be imagined. The attraction lies chiefly in finding the masterpiece so admirably illustrated by $\mathrm{Mr}$ Edmund H. New. In black and white line work of this class he has no equal." (Country Life.)

"We have never seen this book in a more agreeable or appropriate form." (St James's Gazette.)

"Mr Edmund New's drawings are not merely artistic, but full of the poetry of association." (Speaker.)

\section{The Compleat Angler. By Izaak Walton} and CHARles CotTon. Edited, with an Introduction, by Richard Le Gallienne. With Photogravure Portraits of Waiton and Cotton, and over 250 Illustrations and Cover designed by EDMUND H. NEw. Fcap. 4to. Price 15s. net.

"A delightful edition, charmingly illustrated." (Punch.)

"Of Mr Edmund H. New's illustrations we cannot speak too highly. We have never seen better." (Spectator.)

"One of the best editions; one, we cannot help thinking, that Walton himself would have preferred." (Daily Chronicle.)

\section{All About Dogs. A Book for Doggy People.} By Charles Henry Lane. With 85 Full-page Illustrations (including nearly 70 champions) by R. H. MOORE. Gilt top. Demy 8vo. Price 7s. 6d. net.

"One of the most interesting contributions to the literature of the day." (Daily Chronicle.)

"Mr Lane's book is worthy of a place on the shelves of any sporting library." (Outlook.)

"A most interesting, indeed, an entirely fascinating book." (St James's Gazette.) 



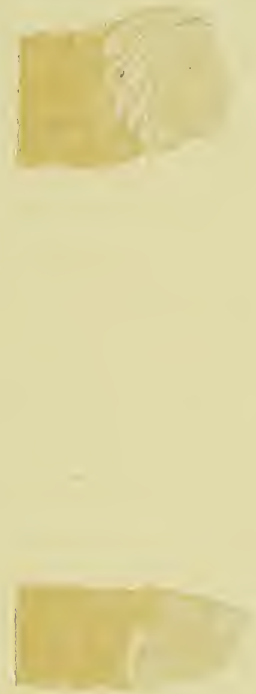
SMITHSONIAN INSTITUTION LIBRARIES

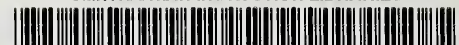

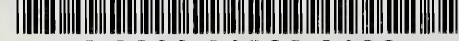

39088010889103 